ISSN 1998-6785

\title{
ОЙКУМЕНА
}

Регионоведческие исследования 



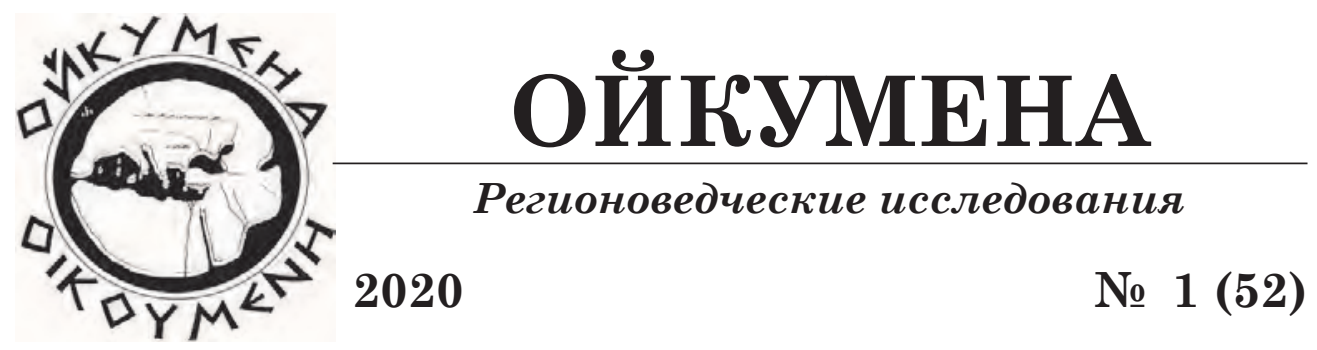

научно-

теоретический журнал

Выходит 4 раза в год

Основан в 2006 г.

\section{ИСТОРИЧЕСКОЕ РЕГИОНОВЕДЕНИЕ}

Подмаскин В. В. Научный вклад военного врача М. М. Добротворского в изучение истории и культуры сахалинских айнов (1867-1872 гг.)

Медведева Л. М. Противостояние фальсификации истории Второй мировой войны в современной российской историографии

\section{КрУглый стол}

Бляхер Л. Е., Барбенко Я. А., Демьяненко А. Н., Журавская Т. Н., Минакир П. А., Рыжова Н. П. Антропология и экономика: возможные направления взаимодействия

\section{ӘКОНОМИКА И ПРИРОДОПОЛЬЗОВАНИЕ}

Рыжова Н. П., Журавская Т. Н. Идея о частной собственности и "реальные" захваты земли

Наумов Ю. А. Об особенностях загрязнения атмосферного воздуха на территории Дальнего Востока России

\section{СОЦИАЛЬНЫЕ И ДЕМОГРАФИЧЕСКИЕ СТРУКТУРЫ}

Липатова Л. Н. Исследование миграционных процессов в современной России с позиции обеспечения экономической безопасности

Бахлов И. В., Кильдюшкина И. Г., Липатова Л. Н. Интеграция и социальная адаптация мигрантов: основы государственной политики и опыт Республики Мордовия

Литвинцева А. И. "Женщины для утешения" как часть феминистского движения корейской диаспоры в Японии

\section{ПОЛИТИЧЕСКИЕ ОТНОШЕНИЯ И УПРАВЛЕНИЕ РЕГИОНОМ}

Козлов Л. Е. Региональная политика России на Дальнем Востоке: обзор актуальных исследований ....

Булах Е. В., Князева А. Р., Цой В. Г. Взаимное влияние процессов формирования гражданской культуры и социально-политического муниципального пространства: от Приамурского Земского собора до настоящего времени

Танцура М. С. Региональный парламентаризм в условиях снижения эффективности системы представительства

Ильин В. Е. Опыт Вьетнама по борьбе снаркотиками .. 112 
Владимирова Д. А., Журбей Е. В., Карловская А. А.

"Мягкая сила" во внешней политике России и Китая: особенности национальных стратегий

Губин А. В. Современный военный потенциал КНДР: неядерный аспект

Алексеев Д. Ю. Возникновение и становление

Народно-Трудового Союза российских солидаристов

НАУЧНАЯ ЖИЗНь

Шабельникова Н. А., Усов А. В. Человек с горящим сердцем: к 80-летию профессора А. П. Деревянко

\section{Редакционная коллегия:}

Т. Г. Римская (главный редактор), Я. А. Барбенко, В.А. Бурлаков, А. В. Винокурова, С.М.Дударенок, Г. Кристофферсен, М. Г. Ганопольский, К. В. Григоричев, А. Н. Демьяненко, Е. В. Журбей (ответственный редактор), И. Н. Золотухин, В. Н. Караман, А. А. Киреев, В. В. Кожевников, А. М. Кузнецов, Ю. В. Латушко, М. М. Лебедева, Д. А. Литошенко, А. Л. Лукин, Ю. А. Наумов, Н. П. Рыжова, С. В. Севастьянов, А. Г. Филипова, О.И. Шестак, Шин Беом-Шик, Сасаки Широ, С. Е. Ячин.

Учредитель: Федеральное государственное бюджетное образовательное учреждение высшего образования "Владивостокский государственный университет экономики и сервиса".

Журнал входит в перечень рецензируемых научных изданий, рекомендованных ВАК при Министерстве образования и науки Российской Федерации Адрес редакции: 692000, Приморский край, г. Находка, ул. Озерная, д. 2. Официальный сайт журнала: http://www.ojkum.ru E-mail: ojkum@rambler.ru

Редактор электронной верстки: В. Н. Караман Графическое оформление: Я. А. Барбенко, В. Н. Караман, В. В. Постников. Корректор: Е. В. Абрамова

Точка зрения редакции не всегда совпадает с точкой зрения авторов. Журнал зарегистрирован Федеральной службой по надзору в сфере массовых коммуникаций, связи и охраны культурного наследия.

Свидетельство о регистрации - серия ПИ № ФС77-30578, выданное 12.12.2007 г. 


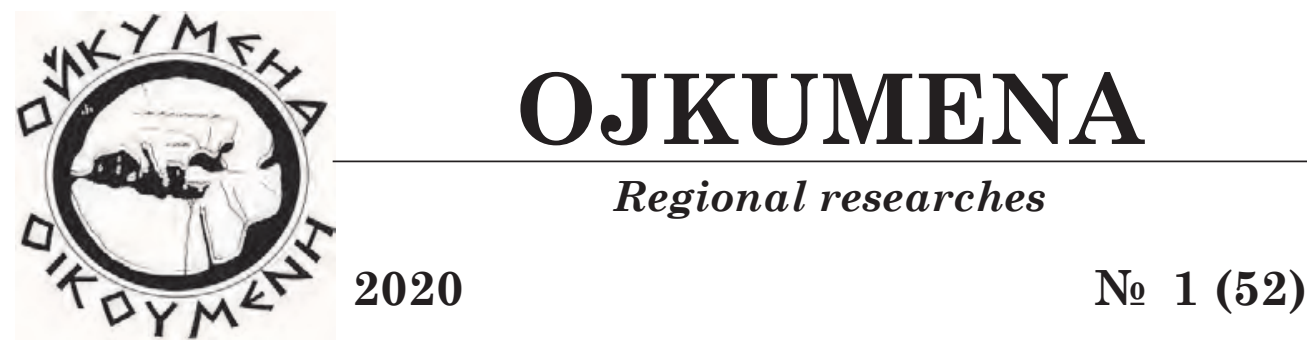

scientifictheoretical journal

Issued 4 times a year

Founded in 2006
Vladivostok 2020

\section{Historical Regional Studies}

Podmaskin V. V. Scientific contribution of military doctor M. M. Dobrotvorsky to the study of the history and culture of the Sakhalin Ainu (1867-1872)

Medvedeva L. M. Opposition to falsification of the history of World War II in modern Russian historiography

\section{Round TABLE}

Blyakher L. E., Barbenko Ya. A., Demyanenko A. N., Zhuravskaia T. N., Minakir P. A., Ryzhova N. P. Anthropology and economics: possible areas of cooperation

\section{ECONOMY AND NATURE}

Ryzhova N. P., Zhuravskaya T. N. The idea of private property and "real" captures of land

Naumov Yu. A. On the features of air pollution in the Russian Far East

\section{Social and Demographic Structures}

Lipatova L. N. The study of migration processes in modern Russia from a position of ensuring economic security

Bakhlov I. V., Kildiyshkina I. G., Lipatova L. N.

Integration and Social Adaptation of Migrants: the Basics of Public Policy and the Experience of the Republic of Mordovia

Litvintseva A. I. "Comfort women" as a part of the feminist movement of the Korean diaspora in Japan

Political Relations and Management of the Region

Kozlov L. E. Regional policy of Russia in the Far East: an overview of current research

Bulakh E. V., Knyazeva A. R., Tsoj V. G. Mutual influence of the culture and the social networks forming process at the local level: from the Amur Zemsky Assembly to the present

Tantsura M. S. Regional parliamentarism in the context of decreasing efficiency of the representation system

Iliyn V. E. Drug prevention and control in Vietnam

\section{World System and INTERNational Regions}

Vladimirova D. A., Zhurbey E. V., Karlovskaya A. A.

"Soft power" in foreign policies of Russia and China:

features of national strategies

Gubin A. V. Contemporary DPRK's military capacity: conventional arms 
Alekseev D. Yu. The emergence and formation

SCIENTIFIC LiFE

Shabelnikova N. A., Usov A. V. A man with

a burning heart: to the 8oth anniversary of professor

A. P. Derevyanko

\section{Editorial board:}

T. G. Rimskaya (Editor-in-chief), Ya.A. Barbenko, V. A. Burlakov, A. V. Vinokurova,

S. M. Dudaryonok, G. Christoffersen, M. G. Ganopolskij, K. V. Grigorichev,

A. N. Demyanenko, E. V. Zhurbey (Editor), I. N. Zolotukhin, V. N. Karaman, A. A. Kireev, V. V. Kozhevnikov, A. M. Kuznetsov, Yu.V. Latushko, M. M. Lebedeva, D. A. Litoshenko, A. L. Lukin, Yu.A. Naumov, N. P. Ryzhova, S. V. Sevastyanov, A. G. Filipova, O. I. Shestak, Beom-Shik Shin, Shiro Sasaki, S. E. Yachin.

Founder: Federal State Budgetary Educational Institution of Higher Education "Vladivostok state university of Economics and Service".

The journal is included in the list of peer-reviewed scientific journals recommended by VAK in the Ministry of Education and Science of Russian Federation Address: 2 Ozernaja St., Nakhodka 692000, Primorskyi krai, Russia. Official site of journal: http://www. ojkum.ru E-mail: ojkum@rambler.ru

Electronic computer is made up by V. N. Karaman Graphic registration: J. A. Barbenko, V. N. Karaman, V. V. Postnikov. Corrector E. V. Abramova

Authors' points of view on the problems under investigation do not necessarily coincide with those of the Editorial Board.

Journal is registered by Federal service on supervision in sphere of mass communications, connection and cultural heritage protection.

Certificate on registration of the journal ser. PI № FS77-30578, given by 12.12.2007. 


\section{Научный вклад военного врача М. М. Добротворского в изучение истории и культуры сахалинских айнов (1867-1872 гг.)}

Среди русских людей, посвятивших жизнь открытию и изучению острова Сахалина, освоению его природных богатств, изучению быта, культуры и языка коренных народностей достойное место занимает военный врач М. М. Добротворский. В исторической литературе мало освещались его общественные дела и деятельность как этнографра $[11$, с. 120-127; 12, с. 16-18; 13 , c. 207-225]. Цель данной работы - попытаться осветить эти вопросы.

Михаил Михайлович Добротворский (27 сентября 1836-1874) родился в селе Стрелки Нижнегородской губернии Арзамасского уезда от бедного священника. Семья состояла из 22 детей, Михаил последний из 7 братьев, получивший полное образование и поступивший на службу. Отец его преподавал фолософию в семинарии, свободно владел латинским и немецким языками. Мать обучала самостоятельно своих детей грамоте. В 1866 г. М. М. Добротворский окончил Медико-хирургическую академию и был направлен на остров Сахалин в распоряжение начальника Сахалинского отряда. Здесь он служил более пяти лет (с 1867 по 1872 гг.) [6, с. 5-6].

В частых поездках по острову, постоянно общаясь с айнами, М. М. Добротворский довольно быстро выучил их язык. Ознакомившись с содержанием отечественных и зарубежных словарей айнского языка (около 40 изданий), он решил создать две части словаря: "Айнско-Русский" и "Русско-Айнский". Он писал о рукописи: "словарь содержит более десяти тысяч айнских слов. Из них 5733 слова, в числе которых 100 собственных имён - мужских и женских и 511 слов географических", записанных автором на Сахалине" [6, с. 28]. Увидеть полный выход в свет своего труда М. М. Добротворский не смог. Ещё на Сахалине, заболев туберкулёзом, он умер 24 октября 1874 г. в возрасте 38 лет. Первая часть "Словаря" была опубликована его братом И. М. Добротворским - профрессором богословия Казанского университета в 1875 г.

На Сахалине М. М. Добротворским было сделано много этнографических записей об айнах, их связях с русским населением острова. В одной из своих работ он отметил: "Айны (слово айну значит и "айнец" и "человек") настоящие туземные жители южной части Сахалина. Этот народ чрезвычайно важен для нас в настоящее время. Мы должны постоянно обращаться к нему в своих нуждах: путешествующие ночуют большей частью в айнских юртах; при недостатке съестных припасов, что случается нередко во время дальних командировок, айны снабжают нас рисом и рыбою; при недостатке юколы мы покупаем её у айнов; случается доставать у них и нитки для неводов. Айны служат нам проводниками по незнакомым местам, а часто и возят на своих нартах или лодках. Кроме того, русские покупают у них соболей, выдр, жир, японский табак и другие вещи, обыкновенно по самым сходным ценам" [9, c. 27].

В своей работе "Южная часть острова Сахалина" он оставил ценное сообщение по численности и расселению айнов, их отношению с японцами в изучаемый период. Он писал: "Племя их населяет всю южную часть Сахалина до залива Терпения; на восточном берегу и до селения Ктяузи - на западном. Отрасли айнского племени заселяют, кроме того, почти весь остр[ов] Матсмай и смежные острова. Здешние айны говорят, что большая часть Курильских островов заселена также айнами... По сведениям, собранным от японцев, ай-

(C) Подмаскин В. В., 2020

ПОДМАСКИН Владимир Викторович, д-р ист. наук, профессор, главный научный сотрудник Института истории, археологии и этнографии народов Дальнего Востока ДВО РАН (2. Владивосток). E-mail: podmaskin@yandex.ru 
нов приписано к разным японским селениям, для работы и оброка 2885 человек обоего пола. В это число не вошли айны, живущие по заливу Терпения и к северу от реки Усури, как независимые от японцев". Добротворский отметил, что в древности айнов на Сахалине было гораздо больше. Главной причиной истребления этноса были опустошительные войны и болезни $[\mathbf{9}, \mathbf{c .} 28$; 7, c. 146].

Учёный отметил влияние японских отношений на культуру айнов. Он писал: "Японцы опрятны, хитры, учтивы в обращении с русскими и надменны в обращении с айнами"... Японцы умели без завоевания поработить себе айнов, доставляя им необходимые домашние вещи, и вместе с тем испортили их нравы. Айны от природы свободные, скромные, откровенные и гостеприимные, под японским влиянием делаются всё более и более льстивыми, скрытными, корыстолюбивыми и нахальными. Японцы сильно испортили и язык айнов, внесши в него много слов и оборотов, совершенно не свойственных айнскому языку" [9, с. 34].

В науке так обстоятельно в этнографоическом отношении этот народ изучен впервые. Добротворского интересовало многое: происхождение айнов, их фризические и психические свойства, хозяйство, пища и напитки, народная медицина, географические названия, рождение и воспитание детей, нравы и обычаи, численность и расселение, религиозные верования.

Изучая антропологический тип айнов, М. М. Добротворский выделил расовые признаки. По строению черепа айны принадлежат к "брахицедалическим прогнатам", а по типу лица - к "монгольской расе". Главная щель косовата, губы толстые. Исследователь заметил, ссылаясь на единственный источник, что "де Nysten относит айнов к Курильской расе Кавказского вида (espece)". Айны низкого роста, крепкого телосложения; цвет кожи у них смуглый с желтоватым оттенком. У женщин цвет лица матово-зелёный (краснощёкая айнка - большая редкость). Здешние айны бреют лоб и темя. Цвет волос - чёрный; иногда в бородах встречается рыжеватый оттенок. Кудрявых волос среди айнов мало. Айнки с 10 лет красят губы масленой сажей. У айнок число детей 3-5; больше 8 детей никогда не родят. Айны - долгожители" [6, c. 32-33].

Особо следует отметить вклад учёного в изучение айнского языка. В составленном им "Айнском словаре" прослеживается творческая лаборатория и метод учёного. Он считал, что "айнский язык есть язык островитян. В нём существует множество слов странных или совсем непонятных для жителей материков. Айны не в далёком будущем будут изучать русский язык и русскую грамоту, поэтому при составлении текста отдал предпочтение русской азбуке", хотя, по его мнению, она и "не совсем близка к звукам айнской речи" $[6$, c. 15, 67]. Его словарь, частично собранный на Сахалине, с добавлением данных, взятых из почти всех существующих тогда источников, признан ныне всеми специалистами как первый настоящий билингвальный словарь языка айнов [1, с. 196-197; 13, с. 213].

В "Словаре" отмечены айнские топонимы: Шаморон котан (японская земля), Шари (местечко на острове Мацма), Игату (12-й Курильский остров или 11-й по счёту Миллера), Шашово (15-й Курильский остров), Шимушир (18-й Курильский остров), Шираои (айнский район), Ширету (мыс, букв. "нос земли"), Шири-беген китай (вершина горы, букв. "пик мира"), Шируру (южное море) [5, с. 74, 432-436]. Из примеров видно, как народная географическая терминология закономерно и активно участвовала в формировании имён собственных - топонимов. Они помогали айнам ориентироваться в пространстве, быстрее осваивать территорию, вести целенаправленный образ жизни [16, c. 18].

По свидетельству М. М. Добротворского, в основе своей географические термины Сахалина и Курильских островов - айнского происхождения; названия Курильских островов - Симусир, Кетой, Мусир, Шияшкотан (Сиоськотан), Онекотан, Поромушир и др. - все айнские. Трепун-Мосири - айнское название Сахалина. Мосири происходит от мо (малый) и сири (место, пространство земли) [9, с. 28]. Гидроним Поротру-Песьпо - приток Кусуная происходит от слов: поро (большой), тру (дорога), песь (утёс), по (дитя). Гора Хунпэ-Сапа похожа на голову рыбы, отсюда и название "голова кеты". Широко представлены топонимы, связанные с хозяйственной деятельностью: Тәсио 
(место, где ставят тэш (загородку для рыбы), Урай уси пэт (река, где ставят ловушки), Урай котан (деревня ловушек) [16, с. 13]. Название посёлка Макомай произошло от наличия здесь куч из створок ракушек маколай айn. Гора Юку ран нупури определяется как пастбище для оленей. Сохранился топоним полуострова Мукара әнтрум (топорный мыс), где жили тончи - люди каменного века. Они, испугавшись айнских воинов, покинули полуостров, оставили на нём каменные топоры, стрелы и горшки [6, с. 32-33].

Описание айнов - это яркое свидетельство их жизни и быта в середине XIX в., когда в традиционной культуре сохранялось много архаических черт, особенно это проявилось в народных знаниях. В прошлом айны пользовались лунным исчислением времени, связанным с наблюдением за фразами луны. Полный цикл изменения формы видимой части лунного диска был зафиксирован в мифологии: "Бог всех светил Чуф камуй живёт на луне. Видят его руки и ноги. При каждой новой луне он рождается, потом взрослеет, становится мальчиком, затем мужчиной и при окончании ущерба луны умирает старцем. Из всех богов Чуф камуй имеет у себя женщину и собаку, которых он захватил, уходя с земли на луну". В названиях лунных фаз отчётливо представлены семь точных наблюдений: насукубб чубб (луна перед полнолунием), нин чуфб (луна перед исчезновением), чуфб сихекел (луна после полнолуния), асись чуфб (молодой месяц), хэлака чуфб (период полнолуния), чубб арекири (первая и последняя четверть луны), тюбутуру, чубб исал хетака (новолуние). Лунный месяц чуфб состоял из 30 дней. Солнце, луна, месяц (календарный), планеты назывались одним словом чубб. Движение солнца днём служило для айнов часами. Они отмечали 8 частей положения солнца до полудня и 7 после полудня [5, с. 167, 428-429].

М. М. Добротворский отметил, что по фразам луны (чуфб, асись_чуфб, насу$\kappa y g 6$ чубб) определяли циклы жертвоприношений, сопоставляли время проведения религиозных праздников и хозяйственной деятельности. О приближении хода рыбы айны узнавали по нарастанию луны. Исследователь отметил, что им известно 12 циклических знаков. Он обнаружил мацунау (первый) и оттолун (последний), вероятно, по его мнению, они связаны с лунным календарём [6, с. $63 ; 5$, с. $428-429,295]$.

Времена года айны отмечали сезонными изменениями и приурочивали их к хозяйственной деятельности (рыбной ловле летом и охоте зимой). Например, mpy чубб (декабрь - январь) - время года, когда на Сахалине появляется первая зимняя дорога. Период дождей (март - апрель) назывался токари понситэ (дождевой тюлень), так как в этот период появляются новорождённые тюлени. Киута (март - апрель) - время роста травы, май аракойнока (корюшка) - нерест корюшки, сичапесьпе (лесная мышь) - июнь (вероятно, название связано с вегетацией грызунов). В сезон сахчехкарапе (июль - август) заготовляли на зиму поджаренную рыбу, а в августе - сентябре ила чубб, ихари чуюб ловили и вялили кету, в сентябре - октябре маута чубб сушили ягоды шиповника. Отмечали суран чубб (ноябрь) - свистящий (бурный) [14, c. 29-33]. М. М. Добротворский записал ещё ряд сезонно-хозяйственных месяцев: гахтра (март), серела (февраль), оннев чубб (февраль у тарайкинских айнов, вероятно, месяц орла), этуон чубб (март, у тарайкинских айнов, вероятно, месяц чёрной вороны) ихулпа чубб (июнь - июль), время, когда крошат рыбу и табак), отарубб караппе (сентябрь, вероятно, месяц плодов шиповника) уребокиталбе (октябрь), сукубб чубб (месяц между первой четвертью и полнолунием) $[5$, с. $54,75,181,226,234,288,311,334,468]$.

Счёт у айнов по пальцам рук и ног. Такой счёт отражал древние представления о человеке и частях его тела с основой 20 . Заготовку лососей измеряли связками по 20 штук. У айнов число го - 20 служило основанием для счёта. Так сине го означает 20 (сине - один), mу го - 40 ( (тре - три), ван го - 200 (ван - десять). Число 200 в свою очередь может стать снова единицей для увеличения счёта $[6$, с. 16]. Имелись и другие измерения, связанные с частями тела. Например, тел маховая сажень (длина вытянутых рук).

На молитвенных палочках инау айны ставили зарубки тохпа в виде отметок пластования тела человека на груди и животе. Судя по этим частям и зарубкам, инау, писал М. М. Добротворский, - "без сомнения, суть остатки человеческих жертвоприношений". Исследователь отмечает сходство инау с 
человеческим телом. У инау есть и голова, и руки, и шея и т. д. [9, с. 47, 59]. Действительно, в фольклоре айнов часто упоминается о людоедстве [15, с. 62; 7, c. 122].

М. М. Добротворский, проявляя интерес к айнской народной медицине, которая, по свидетельству учёного, "мало чем отличалась от собственной русской". Он считал, что некоторые медицинские приёмы являлись самостоятельным изобретением айнов, но скорее всего, они - плод коллективного творчества местного населения (уйльта и нивхов), включая и русских поселенцев. Любые новшества в этой области, благодаря взаимному общению, быстро становились всеобщим достоянием $[8$, с. 48]. Такой взгляд не подразумевал критики или любопытства, когда он пытался выяснить различия между своей и чужой культурами. Врач М. М. Добротворский не занимался строгим выискиванием различий. Изначально все люди отличаются не только по национальности, но и по своей самобытности. На основе этого допущения он выявляет общее для разных национальностей и в то же время отмечает различия у людей, проживающих далеко друг от друга. Возможно, он хотел доказать общность культур различных народов.

По мнению врачей М. М. Добротворского и Н. В. Кирилова научная медицина должна внимательно изучать накопленный целителями эмпирический опыт и научиться применять его рационально [17, с. 90]. История медицины XX в. подтвердила правильность этого предположения.

Айны знали о волшебных свойствах глины и применяли её для лечения множества самых различных заболеваний. Глину успешно использовали при тяжёлых случаях лёгочных заболеваний. Белую глину во время голодовок употребляли в пищу. Лечение глиной относится к методам естественного оздоровления. По сообщению М. М. Добротворского, айны глину четой разводили с водой в больших пропорциях и использовали как рвотное средство $[6$, c. $63 ; 5$, c. 44]. Белая жирная глина у нивхов, орочей и айнов служила добавкой к пище $[18$, с. 60]. Глина способна убивать болезнетворные бактерии, поглощать токсины, запахи и газы. Айны применяли её при отравлениях, кожных заболеваниях, во время эпидемий. Особенно ценилась белая глина (каолин), способная придавать коже эластичность, омолаживать её, активизировать кровообращение. Глина - прекрасный абсорбент, а благодаря своей слабой радиоактивности она обладает антибактериальными действиями.

Сахалинские айны отмечали глину разного цвета - белую, голубую, зелёную, красную, желтую и серую. По их наблюдениям, каждый вид глины имел свои особые свойства. Большой популярностью пользовалась голубая глина. Глину использовали при лечении болезней позвоночника, воспалительных и посттравматических заболеваниях костей, мышц, сухожилий, а также некоторых воспалительных заболеваниях органов пищеварения, женских половых органах; при артритах и полиартритах. Глину применяли вместо мыла, в отличие от последнего она не иссушает кожу, давая ей при этом ряд необходимых микроэлементов.

Большое значение М. М. Добротворский придавал изучению культуры питания айнов. Из просяной шелухи нуся айны научились варить алкогольный напиток тоното (священноё молоко). В основном спиртные напитки изготовляли летом, потому что они активно бродили и быстро прокисали. Алкоголь считался у айнов магическим напитком для жертвы богам. Айны научились самостоятельно делать рисовую водку алала саке. Сварив рисовую кашу, разводили её кипятком и, прибавив рисового солода, заквашивали. Через 5-6 дней получали кисловатый, совершенно белый и густой напиток, "очень вкусный и несколько хмельной". Им известны вина: ширари кору - невыжатое (японское) вино, ширарико шаке - виноградный муст (морс), шири бегень госи - красное вино. Айны пьют вино как во время праздничных церемоний, так и во время печальных событий, а то и вовсе без всякого повода. "Пьяные Айнцы обыкновенно начинают национальный танец (тахкара) во время которого они поют без слов (мнохце) или со словами (юкара). Звуки мнохие гортанные и носовые, неприятные. Танцующий Айнец, если он при этом поёт без слов, очень напоминает Сергачёского медведя-плясуна" [6, c. 38].

Добротворский отметил, что айны едят 4-8 раз в день. Пищей для них служили моллюски, морские ежи, трепанги, осьминоги, а также мясо собак, медведей, тюленей, сивучей и китов. Лакомыми блюдами у айнов считалась: 
печёная молодая черемша кито и варёные луковицы лилии тола. Но главная, а зимой почти исключительная их пища - рыба [6, с. 36-37].

Из грибов айны применяли в пищу только пластинчатые сыроежки карусь. Ореховое дерево поставляло к столу орешки, два вида дуба $m y н н и$, пэро - жёлуди. В легендах говорится, что ребёнка, оставшегося без родителей, воспитывает дуб. Видимо, это связано с тем, что раньше жёлуди были важным продуктом питания, ребёнка, оставшегося без молока матери, поили отваром из желудей. Жёлуди собирали и запасали в основном для кормления медведей в срубах для праздника [6, с. 74].

В "Словаре" приводятся народные названия ядовитых и съедобных растений айнов: шета шуруку борец (букв. "собачий яд"), шиккуmy (polygonum chinense), шири руш мох (букв. "кожа земли"), шгонно шиуруку род борца (аконита), шипусике просо, ширакору лилия чёрного цвета, шиу кина лук (букв. "жёлтое или зеленоватое растение") [5, с. 420, 434, 436, 437, 439, 440 ].

Хорошо представлена лексика морских животных. Особо почиталась айнами касатка чогуеку (морская свинья), потому что убитые её киты и сивучи доставались в пищу людям [6, с. 74]. Отмечалось ещё два вида: этаспе койки и хулпе койки айкисте. Рисунок на коже нерпы ши тукари (большого тюленя) айны сравнивали с черепом черепахи [2, с. 443]. В орнаменте на одежде он изображался в виде неравномерного четырёхугольника.

M. М. Добротворский собрал богатый и ценный материал по религиозным верованиям айнов, которые в какой-то степени проявляют свет на этногенез народности. Он пишет: "Религия айнов выработалась из фетишизма... Айны боготворят бесчисленное множество невидимых существ добрых и злых. Главные из добрых богов следующие: бог гор (нубури-камуй), боги морские (атуй-камуй), боги светил (чуф--камуй), домашние боги (тише-камуй), очажные боги (унджи-камуй), шаманские боги (тусу-камуй), творец мира (котан-карапе), бог подземный (той-камуй), боги рыбной и звериной ловли (койки-камуй) и боги хранители (сикасьма-камуй). Последних бесчисленное множество, так как каждая страна, каждый остров, каждый холм, всякое село, всякое место, имеют своего бога хранителя" [6, с. 40]. Источниками для их написания послужили, прежде всего, собственные полевые наблюдения Добротворского (интервью с местными айнами, записи их легенд и преданий, материалы исследователей этнографии айнов и их языка).

Соратником исследователя был генерал-майор, мировой посредник, этнографр-любитель Федор Михайлович Депрерадович. Он внёс значительный вклад в изучение и освоение Сахалина, способствовал сохранению и распространению знаний о нём. Ф. М. Депрерадовича и М. М. Добротворского объединяли не только служебные дела и личные дружеские отношения. Оба они с 1868 г. являлись действительными членами Восточно-Сибирского отдела Русского географического общества и принимали активное участие в его работе. Опубликованные Ф. М. Депрерадовичем "Этнографические очерки Южного Сахалина", как и публикация М. М. Добротворского "Южная часть острова Сахалина", содержат ценный материал по истории, языку, материальной и духовной культуре айнов [4, с. 1-67; 9, с. 18-34]. За отлично усердную и беспорочную службу на Сахалине М. М. Добротворский был награждён двумя орденами: Св. Станислава 3-й степени и Св. Владимира 4-й степени. В публицистической литературе он отмечен как писатель, лектор и общественный деятель [10, с. 100].

А. И. Костанов опубликовал письма и рапорты М. М. Добротворского к начальнику Сахалинского отряда Ф. М. Депрерадовичу, которые сохранились в фонде (d. 1154) Центрального государственного архива РСФСР Дальнего Востока (г. Владивосток). Писыма опубликованы в "Этнографических исследованиях Сахалинского областного краеведческого музея" в 1986 г. Они раскрывают неизученную страницу истории Сахалина, возникновение первых аптек и лечебных стационаров для русских-переселенцев, гиляков (нивхов), айнов и японцев [11, с. 125-127].

Вклад М. М. Добротворского в становление русской этнографрии XIX в. огромен. Плодотворная работа учёного-медика была оценена по достоинству, его научные труды были переизданы в г. Южно-Сахалинске в 2017 г. [3, с. 96-182]. "Словарём" М. М. Добротворского пользовался учёный-этнографр Бронислав Пилсудский в начале своих занятий айнами и их языком 
[13, с. 211]. Географические айнские названия, извлечённые из "Словаря", вошли в "Топонимический словарь Сахалинской области" Гальцев-Безюка и труды других исследователей $[2 ; 14 ; 16]$.

Итак, из работ М. М. Добротворского мы узнаём, что айны, тесно общаясь с японцами и русскими, сохранили свой языковый фонд, свою своеобразную культуру. В его деятельности на Сахалине прослеживается две особенности: первая - как врача-гражданина, общественного деятеля, вторая - исследователя языка, фольклора, традиционной культуры сахалинских айнов, что даёт право на признание его как учёного. Он впервые дал сравнительное изучение русской и айнской народной медицины, провёл антропологическое, этнографическое и медицинское обследование айнов, населяющих южное побережье Сахалина и этим определил начало изучения сложнейших проблем этногенеза и этнической истории коренных жителей острова.

\section{Литература}

1. Видеман Ф. И., Шифнер А. А. Мнение гг. академиков Ф. И. Видемана и А. А. Шифнера о записке г. Добротворского: "Правописания айнских слов" // Депрерадович Ф. М., Добротворский М. М., Васильев А. В. Аборигены Сахалина глазами русских офицеров (1860-870 гг.) / Сост. В.М. Латышев, Г. И. Дударец. Южно-Сахалинск: Сахалинский областной краеведческий музей, 2017. С. 196-197.

2. Гальцев-Безюк С. Д. Топонимический словарь Сахалинской области. Южно-Сахалинск: Дальневост. кн.. изд-во Сахалинское отделение, 1992. 218 с.

3. Депрерадович Ф. М., Добротворский М. М., Васильев А. В. Аборигены Сахалина глазами русских офицеров (1860-870 гг.) / Сост. В. М. Латышев, Г. И. Дударец. Южно-Сахалинск: Сахалинский областной краеведческий музей, 2017. 290 с.

4. Депрерадович Ф. М. Этнографические очерки Южного Сахалина // Сб. ист.-стат. сведений о Сибири и сопредельных странах. СПб., 1875. Т. 2. Вып. 1. С. 1-67.

5. Добротворский М. М. Айнско-русский словарь. Айну-Русскій итаку-чоменъ. Казань: Университетская типография, 1875. 487 с.

6. Добротворский М. М. Айнско-русский словарь. Приложение // Учён. Зап. Импер. Каз. Унив. Казань: Университетская типография, 1875. 76 с.

7. Добротворский М. М. О кишечных паразитах острова Сахалин // Военно-медицинский журнал (Санкт-Петербург). Сентябрь.. 1872. С. 112-146.

8. Добротворский М.M. Русская простонародная медицина сравнительно с народной медициной сахалинских айнов // Зап. Об-ва врачей г. Казани за 1873 год. Казань: Университетская типография, 1874. С. 1-48.

9. Добротворский М. М. Южная часть острова Сахалина (Извлечено из военно-медищинского отчёта докт [ора] Добротворского за 1868 г.) // Известия Сибирского отдела ИРГО за 1870 г. Иркутск, 1870. Т. 1. № 2-3 (ноябрь-декабрь). С. 18-34.

10. Змеёв Л. Ф. Русские врачи - писатели. СПб., 1899.

11. Костанов А. И. М. М. Добратворский: неопуб̆ликованные письма, рапорты // Материалы к изучению истории и этнографии населения Сахалинской области / отв. ред. М. С. Высоков. Препринт. Южно-Сахалинск: Сахалинский областной краеведческий музей, 1986. С. 120-127.

12. Латышев В. М., Дударец Г. И. Ф.М.Депрерадович, М. М. Добротворский, Васильев А. В. об аборигенах Сахалина (1860-1870 гг.) // Депрерадович Ф. М., Добротворский М. М., Васильев А. В. Аборигены Сахалина глазами русских офицеров (1860-1870 гг.) / Сост. В. М. Латышев, Г. И. Дударец. Южно-Сахалинск: Сахалинский областной краеведческий музей, 2017. С. 7-25.

13. Маевич А. Ф. Айнский словарь М. М Добротворского на фоне других лексикографических материалов в истории изучения айнского языка // Депрерадович Ф. М., Добротворский М. М., Васильев А. В. Аборигены Сахалина глазами русских офицеров (1860-870 гг.) / Сост. В. М. Латышев, Г. И. Дударец. Южно-Сахалинск: Сахалинский областной краеведческий музей, 2017. С. 207-225.

14. Материалы исследования Б. А. Жеребцова по этнографии айнов Южного Сахалина (1946-1948 гг.) / Отв. ред. С. А. Арутюнов. Препринт. Южно-Сахалинск: Невельская типографоя, 1988. 142 с.

15. Пилсудский Б. Фольклор сахалинских айнов / Редактор-составитель В. Латышев. Южно-Сахалинск: Сах. кн. изд-во, Инст. наследия Бронислава Пилсудского, 2002.63 c.

16. Подмаскин В. В. Географические термины айнов как историко-этнографический источник // Труды Института истории, археологии и этнографии ДВО РАН. Этнология и антропология. Т. 23. Владивосток, 2019. С. 7-19. 
17. Тарасенко Д. Б. М. М. Добротворский и Н. В. Кирилов как исследователи народной медицины // Тихоокеанский медицинский научный журнал. 2010. № 4. С. 8790.

18. Штернберг Л. Я.Материалы по изучению гиляцкого языка и фольклора. Образцы народной словесности. Эпос. СПб.: Изд-во Императорской Академии Наук, 1908. T. 1. Ч. 1. $232 \mathrm{c.}$

\section{Транслитерация по ГОСТ 7.79-2000 Система Б}

1. Videman F. I., SHifner A. A. Mnenie gg. akademikov F. I. Videmana i A. A. Shifnera o zapiske g. Dobrotvorskogo: "Pravopisaniya ajnskikh slov" // Depreradovich F. M., Dobrotvorskij M. M., Vasil'ev A. V. Aborigeny Sakhalina glazami russkikh ofitserov (1860-870 gg.) / Sost. V.M. Latyshev, G. I. Dudarets. Yuzhno-Sakhalinsk: Sakhalinskij oblastnoj kraevedcheskij muzej, 2017. S. 196-197.

2. Gal'tsev-Bezyuk S. D. Toponimicheskij slovar' Sakhalinskoj oblasti. Yuzhno-Sakhalinsk: Dal'nevost. kn.. izd-vo Sakhalinskoe otdelenie, 1992. 218 s.

3. Depreradovich F. M., Dobrotvorskij M. M., Vasil'ev A. V. Aborigeny Sakhalina glazami russkikh ofitserov (1860-870 gg.) / Sost. V. M. Latyshev, G. I. Dudarets. Yuzhno-Sakhalinsk: Sakhalinskij oblastnoj kraevedcheskij muzej, 2017. $290 \mathrm{~s}$.

4. Depreradovich F. M. Ehtnograficheskie ocherki Yuzhnogo Sakhalina // Sb. ist.stat. svedenij o Sibiri i sopredel'nykh stranakh. SPb., 1875. T. 2. Vyp. 1. S. 1-67.

5. Dobrotvorskij M. M. Ajnsko-russkij slovar'. Ajnu-Russkij itaku-chomen". Kazan': Universitetskaya tipografiya, 1875. $487 \mathrm{~s}$.

6. Dobrotvorskij M. M. Ajnsko-russkij slovar'. Prilozhenie // Uchyon. Zap. Imper. Kaz. Univ. Kazan': Universitetskaya tipografiya, 1875. 76 s.

7. Dobrotvorskij M. M. O kishechnykh parazitakh ostrova Sakhalin // Voenno-meditsinskij zhurnal (Sankt-Peterburg). Sentyabr'.. 1872. S. 112-146.

8. Dobrotvorskij M.M. Russkaya prostonarodnaya meditsina sravnitel'no s narodnoj meditsinoj sakhalinskikh ajnov // Zap. Ob-va vrachej g. Kazani za 1873 god. Kazan': Universitetskaya tipografiya, 1874. S. 1-48.

9. Dobrotvorskij M. M. Yuzhnaya chast' ostrova Sakhalina (Izvlecheno iz voenno-meditsinskogo otchyota dokt [ora] Dobrotvorskogo za 1868 g.) // Izvestiya Sibirskogo otdela IRGO za 1870 g. Irkutsk, 1870. T. 1. № 2-3 (noyabr'-dekabr'). S. 18-34.

10. Zmeyov L. F. Russkie vrachi - pisateli. SPb., 1899.

11. Kostanov A. I. M. M. Dobratvorskij: neopublikovannye pis'ma, raporty // Materialy k izucheniyu istorii i ehtnografii naseleniya Sakhalinskoj oblasti / otv. red. M. S. Vysokov. Preprint. Yuzhno-Sakhalinsk: Sakhalinskij oblastnoj kraevedcheskij muzej, 1986. S. $120-127$.

12. Latyshev V. M., Dudarets G. I. F. M. Depreradovich, M. M. Dobrotvorskij, Vasil'ev A. V. ob aborigenakh Sakhalina (1860-1870 gg.) // Depreradovich F. M., Dobrotvorskij M. M., Vasil'ev A. V. Aborigeny Sakhalina glazami russkikh ofitserov (1860-1870 gg.) / Sost. V. M. Latyshev, G. I. Dudarets. Yuzhno-Sakhalinsk: Sakhalinskij oblastnoj kraevedcheskij muzej, 2017. S. 7-25.

13. Maevich A. F. Ajnskij slovar' M. M Dobrotvorskogo na fone drugikh leksikograficheskikh materialov v istorii izucheniya ajnskogo yazyka // Depreradovich F. M., Dobrotvorskij M. M., Vasil'ev A. V. Aborigeny Sakhalina glazami russkikh ofitserov (1860870 gg.) / Sost. V. M. Latyshev, G. I. Dudarets. Yuzhno-Sakhalinsk: Sakhalinskij oblastnoj kraevedcheskij muzej, 2017. S. 207-225.

14. Materialy issledovaniya B. A. Zherebtsova po ehtnografii ajnov Yuzhnogo Sakhalina (1946-1948 gg.) / Otv. red. S. A. Arutyunov. Preprint. Yuzhno-Sakhalinsk: Nevel'skaya tipografiya, 1988. $142 \mathrm{~s}$.

15. Pilsudskij B. Fol'klor sakhalinskikh ajnov / Redaktor-sostavitel' V. Latyshev. Yuzhno-Sakhalinsk: Sakh. kn. izd-vo, Inst. naslediya Bronislava Pilsudskogo, 2002. 63 s.

16. Podmaskin V. V. Geograficheskie terminy ajnov kak istoriko-ehtnograficheskij istochnik // Trudy Instituta istorii, arkheologii i ehtnografii DVO RAN. EHtnologiya i antropologiya. T. 23. Vladivostok, 2019. S. 7-19.

17. Tarasenko D. B. M. M. Dobrotvorskij i N. V. Kirilov kak issledovateli narodnoj meditsiny // Tikhookeanskij meditsinskij nauchnyj zhurnal. 2010. № 4. S. 87-90.

18. Shternberg L. Ya. Materialy po izucheniyu gilyatskogo yazyka i fol'klora. Obraztsy narodnoj slovesnosti. EHpos. SPb.: Izd-vo Imperatorskoj Akademii Nauk, 1908. T. 1. CH. $1.232 \mathrm{~s}$. 
Подмаскин В. В. Научный вклад военного врача М. М. Добротворского в изучение истории и культуры сахалинских айнов (1867-1872 гг.).

Статья посвящена научной деятельности военного врача, общественного деятеля, краеведа, языковеда, этнографа, соратника Ф. М. Депрерадовича Михаилу Михайловичу Добротворскому. Во время лечебной практики по Южному Сахалину он собрал ценный материал по языку и этнографии сахалинских айнов, который в обобщённой форме содержится в уникальном "Айнско-русском словаре" и ряде научных работ. В данной статье даётся оценка трудов исследователя. В современных условиях особенно важно информировать читателей о научном вкладе врачей в этнографию и антропологию коренных народов Дальнего Востока России. Лингвисты, географы, биологи, демографы, фольклористы, этнографы, антропологи, историки и врачи найдут интересную и нужную информацию, отражающую историю и культуру островного айнского общества второй половины XIX в., оставленную нам учёным-медиком М. М. Добротворским.

Ключевые слова: айны, языковые особенности, этнографбия и антропология, топонимика, народные знания, религиозные воззрения, Сахалин второй половинь XIX в.

Podmaskin V. V. Scientific contribution of military doctor M. M. Dobrotvorsky to the study of the history and culture of the Sakhalin Ainu (1867-1872).

The article is devoted to the scientific activity of the military doctor, public figure, local historian, linguist, ethnographer, colleague F. M. Depreradovich Mikhail Mikhailovich Dobrotvorsky. During his medical practice in southern Sakhalin, he collected valuable material on the language and Ethnography of the Sakhalin Ainu, which is contained in a generalized form in a unique "Ainu-Russian dictionary" and a number of scientific works. This article gives an assessment of the researcher's works. Linguists, folklorists, ethnographers, anthropologists and doctors will find interesting and useful information reflecting the history and culture of the Ainu society of the second half of the XIX century, left to us by the medical scientist M. M. Dobrotvorsky.

Key words: Ainu, language peculiarities, anthropology, toponymy, folk medicine, geographical names, folk calendar, religious beliefs, folklore, Sakhalin

Для цитирования: Подмаскин В. В. Научный вклад военного врача М. М. Добротворского в изучение истории и культуры сахалинских айнов (1867-1872 гг.) // Ойкумена. Регионоведческие исследования. 2020. № 1. C. 5-12. DOI: 10.24866/1998-6785/2020-1/5-12

For citation: Podmaskin V. V. Scientific contribution of military doctor M. M. Dobrotvorsky to the study of the history and culture of the Sakhalin Ainu (1867-1872) // Ojkumena. Regional researches. 2020. № 1. P. 5-12. DOI: 10.24866/1998-6785/2020-1/5-12 


\section{Противостояние фальсификации истории Второй мировой войны в современной российской историографии}

В обострившемся в настоящее время геополитическом противостоянии ведущих мировых держав пересмотр взглядов на ход и итоги Второй мировой войны выступает средством идеологической борьбы и манипуляции общественным сознанием, которое настойчиво используется в навязывании международному сообществу антироссийского дискурса. Очевидной демонстрацией поддержки бездоказательной ревизии исторических событий стала принятая в сентябре 2019 г. резолюция Европейского парламента, в которой на СССР возлагается ответственность за начало Второй мировой войны наравне с гитлеровской Германией. Особо непримиримую позицию в вопросе искажения правды о вкладе Советского Союза в победу над фрашизмом занимают поощряемые влиятельными западными политиками представители таких стран бывшего социалистических лагеря, как Польша, республики Прибалтики и Украина. На территории этих государств уничтожаются и оскверняются памятники советским воинам-освободителям. В феврале 2019 г. российский посол в Польше С. Андреев сообщил, что в этой стране в период с 2014 г. снесли порядка 100 памятников советским солдатам. В январе 2020 г. польский Сейм, пренебрегая историческими данными, принял резолюцию с утверждениями о том, что нацистская Германия и коммунистический Советский Союз развязали Вторую мировую войну.

Российские исследователи отмечают, что военная история оказалась в эпицентре борьбы за национальную безопасность нашей страны как во внутренней, так и во внешней сферах [12, с. 77] и фральсификация исторических событий должна пониматься как когнитивное оружие [13]. В решении современных геополитических проблем все чаще используется психолого-информационное воздействие на население $[2,17,19]$. Нельзя не согласиться с мнением Г. Н. Нурышева, согласно которому психологические, ментальные, поведенческие войны с учетом этнических, гендерных и возрастных особенностей людей деформируют массовое общественное сознание и порождают массовое деструктивное поведение. В качестве примера разрушительной пропаганды, снижающей геополитическую субъектность России, Г. Н. Нурышев приводит высказывания представителей "либеральной, антироссийской оппозиции" А. Минкина, А. Гозмана, Е. Ихлова [17, с. 65, 70]. В. Н. Бенда, основываясь на анализе тенденциозных суждений французских авторов М. Гарде, Ж. Мордаля, английского историка Э. Бивора, отмечает, что фральсификация истории Второй мировой войны направлена на то, чтобы сделать Россию изгоем мирового сообщества, замаскировать истинную сущность агрессивной информационной политики, проводимой в настоящее время входящими в блоки НАТО и Евросоюза странами; убедить народы в незыблемости западной системы ценностей и необходимости проведения антироссийского курса [5].

Авторы подчеркивают, что дезинформация опасна как со стороны западных институтов, так и со стороны российских авторов [18]. Подлинная история Победы над фрашизмом является фрактором формирования мировоззрения и духовного здоровья нации. На фроне кардинальных изменений общественной жизни следует сохранять память о великом и трагическом событии [23].

Противостояние искажению истории одного из переломных моментов в развитии человечества представляется актуальной задачей. В данной работе

(C) Медведева Л. М., 2020

МЕДВЕДЕВА Людмила Михайловна, д-р ист. наук, профессор, заведующая кафредрой истории, археологии и этнологии Института истории, археологии и этнологии ДВО РАН (2. Владивосток). E-mail: medvedeva_1@mail.ru 
поставлена цель рассмотреть, как она решается в российской историографии последних лет.

В попытках отстоять достоверность изложения истории Второй войны российские ученые на современном этапе продвигают тенденцию расширения предметного поля исследований и углубленного изучения его объектно-субъектной природы. Сегодня авторы обращаются к сюжетам, которые ранее не подвергались обсуждению в силу политических соображений и разного рода союзнических обязательств. При этом авторы призывают к объективному отражению истории Второй мировой войны.

Одним из трендов фральсификации исторических событий являются попытки не только умалить роль Советского Союза в победе над фашизмом, но и обвинить его в сговоре с Германией и развязывании войны. Главной целью фальсификации истории Второй мировой войны становится не только пересмотр ее итогов, но и реабилитация преступных идеологий, их институциональное возрождение и легализация. Фальсификация, основанная на знаке равенства между гитлеровской Германией и Советским Союзом, возложение на них равной ответственности за развязывание Второй мировой войны направлены на то, чтобы Советский Союз оказался не среди освободителей, а среди тех, кто осуждается за преступления против человечества $[17, \mathbf{c . 6 9 ]}$.

Рассматривая с научных позиций условия, которые привели к развязыванию полномасштабной войны, авторы сходятся во мнении, что они сложились задолго до сентября 1939 г. Как справедливо замечает А. А. Гришин, отправной точкой реализации планов германской агрессии можно считать приход к власти Гитлера и его партии в 1933 г. [10, с. 11]. Исследователи выстраивают цепь событий, которые сформировали благоприятную среду для нарастания глобального конфрликта. Они обращают внимание на попытки европейских стран пойти на соглашение с Германией в период, предшествовавший подписанию пакта Молотова - Риббентропа. В. Э. Багдасарян [2] и И. В. Бочарников [7], напоминают о заключении в 1933 г. пакта согласия и сотрудничества четырех стран - Франции, Великобритании, Германии и Италии. Столбов пишет, что это был сговор английского и фрранцузского правительств с германским и итальянским фашизмом, уже тогда не скрывавшим своих агрессивных намерений [20, с. 81]. 26 января 1934 г. была подписана Декларация о неприменении силы между Германией и Польшей, рассчитывавшей не только обезопасить себя, но и при поддержке более сильного партнера расширить свои границы.

Законом об обороне в марте 1935 г. в Германии вводилась всеобщая воинская обязанность. В стране возрождались вооруженные силы и особое внимание уделялось созданию авиации. Заключение в указанном году англо-германского морского соглашения позволило Германии развернуть строительство подводных лодок и надводного военного фрлота.

Одновременно происходило расширение территории Германии. Посредством плебисцита была присоединена Саарская область, что укрепило престиж Гитлера внутри страны как объединителя немецкой нации. В фарватере политики территориального передела в это время повела себя Италия, вторгшаяся в Эфиопию. А в марте 1936 г. германские войска, нарушив Версальский договор, вошли в находившуюся под управлением Лиги наций, демилитаризованную Рейнскую зону. Франция и Англия не предприняли реальных действий, которые могли помешать дальнейшему распространению агрессии.

Отмечая указанные исторические вехи, российские ученые показывают картину укрепления позиций фашистских государств при попустительстве ведущих европейских стран, действия которых получили в свое время адекватную оценку современников событий, в том числе и известных европейских политиков. Так, по мнению У. Черчилля, все, что было создано немцами до 1935 г., уступало по численности и мощи французской армии, не говоря уже о ее союзниках [22, с. 36]. Агрессия Гитлера до середины 1936 г. опиралась не на силу Германии, а на разобщенность и робость Франции и Англии, а также на изоляцию Соединенных Штатов. Совместные действия этих стран могли "предотвратить Вторую мировую войну или по крайней мере оттянуть ее возникновение на неопределенно долгий срок" [22, с. 50].

Пока лидеры западных держав питали иллюзии относительно планов Гитлера, Германия вооружалась и делала один решительный шаг за другим. 
Аншлюс Австрии расширил жизненное пространство нацистов, а отсутствие единодушного осуждения и противодействия мирового сообщества придало им большей уверенности.

Ключевым событием в развязывании Второй мировой войны Н. Б. Найденко [16], И. В. Бочарников [7, с. 34], В. П. Столбов [20, с. 81], В. М. Шелюто [24, с. 81] и другие авторы называют Мюнхенское соглашение. Оно не только открыло путь к разделу Чехословакии, в котором поучаствовали Германия, Польша и Венгрия, но и знаменовало собой крушение версальско-вашингтонской системы международных отношений. Политика "умиротворения" агрессора за счет "малых" государств, как подчеркивают О. А. Вусатюк [9] и Ю. В. Морозов [15], была направлена на то, чтобы столкнуть Германию c CCCP.

Очевидно, что вплоть до конца 1930-х гг., руководствуясь антикоммунистическими настроениями, западные державы не рассматривали Советский Союз в качестве равноправного партнера в борьбе против Германии. Как отмечает М. Мельтюхов, определенную роль в срыве англо-фрранко-советских переговоров сыграла позиция восточноевропейских соседей СССР, которые заявляли Англии и Франции о своей незаинтересованности в гарантии их независимости с участием советской стороны [14, с. 87].

А. В. Ревякин указывает, что самую протяженную границу на западе Советский Союз имел с Польшей и по многим причинам эта граница вызывала у советских властей повышенное беспокойство. Отсюда и двойственное отношение к Польше - в зависимости от обстоятельств эта страна могла служить либо плацдармом для нападения на ССCP с запада, либо серьезной преградой на пути агрессора [4, с. 77]. Содержание впервые опубликованных А. Н. Артизовым и С. В. Кудряшовым [1] донесений фрранцузских военных атташе в СССР и Польше министру национальной обороны и военному министру Франции Э. Даладье в июле 1939 г. указывает на то, что Польша отвергла предложения, которые могли послужить основой ее переговоров с Францией, СССР и Англией. Своими действиями она расстроила планы фрранцузской и советской дипломатии, направленные на создание единого антифашистского фрронта в восточной Европе. Русофобия в восточно-европейских и прибалтийских странах преграждала путь к договоренностям с Советским Союзом. Кроме того, как замечает В. Э. Багдасарян [2], Финляндия, Польша, Венгрия и Румыния строили великодержавные проекты, предполагавшие территориальную экспансию в том числе и за счет России. Эти государства не могли самостоятельно реализовать свои амбициозные планы, поэтому, как и некоторые другие страны Европы и Азии, поддержали создававшиеся фашистскими государствами альянсы - Антикоминтерновский пакт 1936 г. и Берлинский пакт 1940 г.

В. В. Балахнин [3] приводит аргументы, свидетельствующие о том, что Советский Союз в 1930-е гг. предпринимал настойчивые усилия для создания антифашистского блока, отодвинув на задний план идеи мировой революции и идейное противостояние со странами западной демократии и нацистской Германии. Оказавшись между двумя очагами напряженности, без союзников, испытывая трудности социально-экономического развития и не располагая убедительным военно-промышленным потенциалом, Советский Союз к осени 1939 г. исчерпал свои возможности договориться с европейскими странами об объединении усилий против фашистской угрозы. Для обеспечения безопасности осталась возможность договориться с Германией, которая охотно шла на контакт.

Выражая доминирующую в российской историографии точку зрения, Н. М. Щербин пишет, что в 1939 г. СССР был вынужден подписать пакт о ненападении с Германией. Этот шаг был предпринят с целью оттянуть время и получить возможность для подготовки к войне. Присоединение Западной Украины и Западной Белоруссии, Эстонии, Литвы, Латвии и территорий в Финляндии способствовало улучшению стратегического положения страны, что следует понимать как подготовку к ее обороне [25]. М. Мельтюхов, полемизируя с Д. Г. Наджафовым, Н. С. Лебедевой и А. Г. Ложкиным, заявляющими о насильственном присоединении Прибалтийских государств, обосновывает изменение западных границ СССР перед войной с точки зрения международного права [14]. Ю. В. Морозов замечает, что германо-советский договор о не- 
нападении был лишь ответной реакцией Москвы на Мюнхенский сговор [15, c. 54]. Авторы отвергают попытки возложить вину за развязывание войны на Советский Союз. Так, обращаясь к высказыванию польского профрессора Г. Ольшовски о том, что пакт между Гитлером и Сталиным стал сигналом для начала Второй мировой войны, О. А. Вусатюк указывает на беспочвенность подобного обвинения и несостоятельность стремления поляков предстать невинной жертвой агрессивной политики СССР и Германии $[\mathbf{1 4}, \mathbf{c .}$ 5-6]. Осмысливая и интерпретируя пакт Молотова-Риббентропа не как изолированное, а как обусловленное развивавшимися во времени и пространстве фракторами событие, авторы показывают его истинное содержание и значение.

Ю. В. Морозов, С. М. Воробьев, М. И. Дробжев и другие авторы в противовес утверждениям западных историков о том, что поворотные пункты войны связаны с действиями англо-американских союзников, приводят данные о сосредоточении основных сил фрашистской Германии на восточном направлении $[\mathbf{1 1}, \mathbf{8 , 6}$. На 1 мая 1942 г. на восточном фрронте немцы сосредоточили 217 дивизий и 20 бригад, или 80 \% всех сухопутных войск Германии и ее союзников, а также три из пяти немецких воздушных фолотов [8, с. 48].

В. Э. Багдасарян подчеркнул, что в условиях, когда многие включаются в информационно-психологический поход против России, преуменьшая роль СCCP в победе над фрашизмом и обвиняя его в агрессии и имперских устремлениях, важно раскрыть сущность экспансионистской политики не только стран оси зла - Германии, Японии, Италии, - но и других субъектов международных отношений. В. Э. Багдасарян указывает на то, что Великобритания и США, проводившие военные операции в Южной Италии и Северной Афррике, решали, прежде всего, задачи укрепления своего влияния в Средиземноморье [2, с. 156]. С. М. Воробьев пишет о преднамеренном оттягивании открытия второго фронта. Союзники исходили из того, что СССР и Германия выйдут из войны истощенными, что обеспечит англо-американское господство в послевоенном мире [8, с. 47]. К открытию второго фрронта союзников подтолкнули успехи Советского Союза в ведении войны.

Ключевая роль СССР в победе над нацизмом во Второй мировой войне обеспечила странам европейского сообщества право на существование и суверенное развитие [7]. Российские авторы отстаивают право граждан своего Отечества гордиться подвигом советской армии. Ю. В. Пикалов и С. А. Головин, обращаясь к историческим фактам, дают критическую оценку выводам А. В. Чечулина, ставящим под сомнение мужество советских солдат [18]. Ю. В. Морозов подчеркивает, что основой Победы стали передовой характер советской стратегии и тактики, героизм советских воинов, давших отпор агрессору, и самоотверженность тружеников тыла, обеспечивших быстрый рост военного производства и создавших лучшие образцы военной техники [15, c. 56-58].

Обосновывая решающую роль Советского Союза в победе над фрашизмом, российские исследователи обращаются к анализу широкого круга источников и свидетельств. Д. Н. Филипповых в своей статье приводит многочисленные высказывания политических, общественных и военных деятелей западных стран в период ведения войны и подведения ее итогов, свидетельствующие о том, что они отдавали должное вкладу СССР в Победу и у них не было сомнений в том, что это, прежде всего, заслуга Советской России [21].

В результате анализа российской историографии, посвященной критике фральсификации истории Второй мировой войны, следует сделать следующие выводы:

- изменился ракурс рассмотрения вопросов с целью обоснования позиции участников Второй мировой войны и оценки их действий;

- использованы новые источники информации и аргументы;

- усилился дискуссионный характер рассмотрения вопросов;

- пересмотрены традиционные взгляды на роль отдельных участников, которые ранее представлялись исключительно как жертвы фрашизма;

- действия субъектов международных отношений рассматриваются не в качестве одномоментных актов, а в широком историческом контексте, что позволяет понять их мотивы и историческую обусловленность;

- внесен вклад в научное объяснение содержания и роли информационно-психологических войн. 
Все это позволяет российским исследователям противостоять искажению истории и продвинуться в достижении объективного отражения событий прошлого. В условиях неослабевающего натиска фральсификаторов истории Второй мировой войны, соответствующая оценка их действий помогает уяснить истинные устремления и современные геополитические установки ряда стран. Борьба за правдивое изложение событий - это борьба за умы молодого поколения, за национальное самосознание и, в конечном счете, за будущее России.

\section{Литература}

1. Артизов А. Н. Кудряшов С. В. Французские документы о начале второй мировой войны// Вестник МГИМО Университета. 2019. № 3 (66). С. 202-246.

2. Багласарян В. Э. Геополитические проекты Второй мировой войны в актуальной повестке современной политики // Среднерусский вестник общественных наук. 2019. T. 14. № 3. С. 151-174.

3. Балахнин В. В. Геополитическое противостояние накануне и в начале второй мировой войны // Гуманитарные проблемы военного дела. 2018. № 3 (16). С. 54-60.

4. Белые пятна - черные пятна: Сложные вопросы в российско-польских отношениях: научное издание / Под ред. А. В. Торкунова, А. Д. Ротфельда. М.: Аспект Пресс, 2019. 823 c.

5. Бенда В. Н. Критика фальсификаций и искаженных трактовок истории Второй мировой и Великой Отечественной войн в отечественной историографии // Modern Science. 2019. № 8. C. 36-55.

6. Бобринев К. С., Артамонов Е. С. Фальсификации истории Великой Отечественной войны. М.: ЛитРес: Самиздат, 2019. 210 с.

7. Бочарников И. В. Политика "умиротворения" нацизма как фрактор развязывания второй мировой войны (к 80-летию начала второй мировой войны) // Человеческий капитал. 2019. № 9 (129). С. 29-37.

8. Воробьев С. М. Дискредитация роли Советского государства западными державами в победе во второй мировой войне (1939-1945 гг.) // Теория государства и права. 2019. № 2. С. 46-51.

9. Вусатюк О.А. Польша-поджигатель Второй мировой войны // Свободная мысль. 2019. № 4 (1676). С. 5-18.

10. Гришин А. А. Великая Отечественная война и ее фральсификаторы // Вестник Московского университета МВД России. 2015. № 5 С. 10-13.

11. Дробжев М. И. Фальсификаторы истории Второй мировой и Великой Отечественной войны Советского Союза // Вестник Тамбовского университета. Серия: Общественные науки. 2015. № 3 (3). С. 77-88.

12. Кикназде В. Г. История Второй мировой войны: противодействие попыткам ее фальсификации и искажения в ущерб международной безопасности // Вестник МГИМО Университета. 2015. № 4 (43). С. 74-83.

13. Ливцов В. А., Пожидаев А. С., Николаева К. С. Проблема фальсификации истории второй мировой войны: Орловско-Курская дуга // Среднерусский вестник общественных наук. 2017. Т. 12. 3;. С. 100-107.

14. Мельтюхов М. Изменение западных границ Советского Союза во время второй мировой войны // Журнал российских и восточноевропейских исследований. 2018. № 1 (15). C. $85-106$.

15. Морозов Ю. В. Фальсификация итогов второй мировой войны в рамках информационной борьбы против России // Национальные интересы: приоритеты и безопасность. 2015. Т.11. № 25 (310). С. 50-63.

16. Найденко Б. Н. До и после "секретных протоколов" 1939 г.: что нужно противопоставить фальсификаторам истории? // Конференциум АСОУ: сборник научных трудов и материалов научно-практических конференций. 2015. № 4. С. 1340-1350.

17. Нурышев Г. Н. Информационно-психологические операции в системе гибридных войн // Геополитика и безопасность. 2017. № 2 (38). С. 65-73.

18. Пикалов Ю. В., Головин С. А. Попытки фальсификации истории Курильской операции Советских войск (август 1945 г.) // Общество: фрллософия, история, культура. 2018. № 1. C.103-106.

19. Пономарева Е. Г. Россия и Запад: неизбежно ли противостояние? // Свободная мысль. 2019. 3 5. (1677). С. 211-217.

20. Столбов В. П. К вопросу о фальсификации истории Второй мировой войны $(К$ 80-летию начала второй мировой войны) // Известия высших учебных заведений. Серия: Экономика, финансы и управление производством. 2019. № 3 (41). С. $79-87$.

21. Филипповых Д. Н. Переиграть победу невозможно! (к вопросу профрессиональной компетентности фальсификаторов истории Второй мировой войны) // Военный академический журнал. 2015. № 2 (6). С. 20-28. 
22. Черчилль У. С. Вторая мировая война: В 3-х кн. Кн. 3. М.: Альпина нонфокшн, 2010. 748 с.

23. Шабельникова Н.А. Великая Победа в памяти поколений: Вторая мировая война в современной дальневосточной историографии // Клио. 2019. № 1 (145). С. 36.

24. Шелюто В. М. Отождествление тоталитарных идеологий как способ фальсифрикации истории // Культура и цивилизация (Донецк). 2017. № 1 (5). С. 77-86.

25. Щербин Н. М. СССР во второй мировой войне: аргументы против мифов // Гуманитарные проблемы военного дела. 2018. № 1 (14). С. 128-134.

\section{Транслитерация по ГОСТ 7.79-2000 Система Б}

1. Artizov A. N. Kudryashov S. V. Frantsuzskie dokumenty o nachale vtoroj mirovoj vojny// Vestnik MGIMO Universiteta. 2019. № 3 (66). S. 202-246.

2. Baglasaryan V. Eh. Geopoliticheskie proekty Vtoroj mirovoj vojny v aktual'noj povestke sovremennoj politiki // Srednerusskij vestnik obshhestvennykh nauk. 2019. T. 14. № 3. S. 151-174.

3. Balakhnin V. V. Geopoliticheskoe protivostoyanie nakanune i v nachale vtoroj mirovoj vojny // Gumanitarnye problemy voennogo dela. 2018. № 3 (16). S. 54-60.

4. Belye pyatna - chernye pyatna: Slozhnye voprosy v rossijsko-pol'skikh otnosheniyakh: nauchnoe izdanie / Pod red. A. V. Torkunova, A. D. Rotfel'da. M.: Aspekt Press, 2019. $823 \mathrm{~s}$.

5. Benda V. N. Kritika fal'sifikatsij i iskazhennykh traktovok istorii Vtoroj mirovoj i Velikoj Otechestvennoj vojn v otechestvennoj istoriografii // Modern Science. 2019. № 8. C. $36-55$.

6. Bobrinev K. S., Artamonov E. S. Fal'sifikatsii istorii Velikoj Otechestvennoj vojny. M.: LitRes: Samizdat, 2019. $210 \mathrm{~s}$.

7. Bocharnikov I. V. Politika "umirotvoreniya" natsizma kak faktor razvyazyvaniya vtoroj mirovoj vojny (k 80-letiyu nachala vtoroj mirovoj vojny) // CHelovecheskij kapital. 2019. № 9 (129). S. 29-37.

8. Vorob'ev S. M. Diskreditatsiya roli Sovetskogo gosudarstva zapadnymi derzhavami v pobede vo vtoroj mirovoj vojne (1939-1945 gg.) // Teoriya gosudarstva i prava. 2019. № 2. S. 46-51.

9. Vusatyuk O. A. Pol'sha - podzhigatel' Vtoroj mirovoj vojny // Svobodnaya mysl'. 2019. № 4 (1676). S. 5-18.

10. Grishin A. A. Velikaya Otechestvennaya vojna i ee fal'sifikatory // Vestnik Moskovskogo universiteta MVD Rossii. 2015. № 5 S. 10-13.

11. Drobzhev M. I. Fal'sifikatory istorii Vtoroj mirovoj i Velikoj Otechestvennoj vojny Sovetskogo Soyuza // Vestnik Tambovskogo universiteta. Seriya: Obshhestvennye nauki. 2015. № 3 (3). S. 77-88.

12. Kiknazde V. G. Istoriya Vtoroj mirovoj vojny: protivodejstvie popytkam ee fal'sifikatsii i iskazheniya v ushherb mezhdunarodnoj bezopasnosti // Vestnik MGIMO Universiteta. 2015. № 4 (43). S. 74-83.

13. Livtsov V. A., Pozhidaev A. S., Nikolaeva K. S. Problema fal'sifikatsii istorii vtoroj mirovoj vojny: Orlovsko-Kurskaya duga // Srednerusskij vestnik obshhestvennykh nauk. 2017. T. 12. 3;. S. 100-107.

14. Mel'tyukhov M. Izmenenie zapadnykh granits Sovetskogo Soyuza vo vremya vtoroj mirovoj vojny // ZHurnal rossijskikh i vostochnoevropejskikh issledovanij. 2018. № 1 (15). S. $85-106$.

15. Morozov Yu. V. Fal'sifikatsiya itogov vtoroj mirovoj vojny v ramkakh informatsionnoj bor'by protiv Rossii // Natsional'nye interesy: prioritety i bezopasnost'. 2015. T.11. № 25 (310). S. 50-63.

16. Najdenko B. N. Do i posle "sekretnykh protokolov" 1939 g.: chto nuzhno protivopostavit' fal'sifikatoram istorii? // Konferentsium ASOU: sbornik nauchnykh trudov i materialov nauchno-prakticheskikh konferentsij. 2015. № 4. S. 1340-1350.

17. Nuryshev G. N. Informatsionno-psikhologicheskie operatsii v sisteme gibridnykh vojn // Geopolitika i bezopasnost'. 2017. № 2 (38). S. 65-73.

18. Pikalov Yu. V., Golovin S. A. Popytki fal'sifikatsii istorii Kuril'skoj operatsii Sovetskikh vojsk (avgust 1945 g.) // Obshhestvo: filosofiya, istoriya, kul'tura. 2018. № 1. S.103-106.

19. Ponomareva E. G. Rossiya i Zapad: neizbezhno li protivostoyanie? // Svobodnaya mysl'. 2019. 3 5. (1677). S. 211-217.

20. Stolbov V. P. K voprosu o fal'sifikatsii istorii Vtoroj mirovoj vojny (K 80-letiyu nachala vtoroj mirovoj vojny) // Izvestiya vysshikh uchebnykh zavedenij. Seriya: Ehkonomika, finansy i upravlenie proizvodstvom. 2019. № 3 (41). S. 79-87.

21. Filippovykh D. N. Pereigrat' pobedu nevozmozhno! (k voprosu professional'noj kompetentnosti fal'sifikatorov istorii Vtoroj mirovoj vojny) // Voennyj akademicheskij zhurnal. 2015. № 2 (6). S. 20-28. 
22. Cherchill' U. S. Vtoraya mirovaya vojna: V 3-kh kn. Kn. 3. M.: Al'pina non-fikshn, 2010. $748 \mathrm{~s}$

23. Shabel'nikova N.A. Velikaya Pobeda v pamyati pokolenij: Vtoraya mirovaya vojna v sovremennoj dal'nevostochnoj istoriografii // Klio. 2019. № 1 (145). S. 36.

24. Shelyuto V. M. Otozhdestvlenie totalitarnykh ideologij kak sposob fal'sifikatsii istorii // Kul'tura i tsivilizatsiya (Donetsk). 2017. № 1 (5). S. 77-86.

25 . Shherbin N. M. SSSR vo vtoroj mirovoj vojne: argumenty protiv mifov // Gumanitarnye problemy voennogo dela. 2018. № 1 (14). S. 128-134.

Медведева Л. М. Противостояние фальсификации истории Второй мировой войны в современной российской историографии.

В обострившемся в настоящее время геополитическом противостоянии ведущих мировых держав пересмотр взглядов на ход и итоги Второй мировой войны выступает средством идеологической борьбы и манипуляции общественным сознанием, которое настойчиво используется в навязывании международному сообществу антироссийского дискурса. Российские ученые направляют усилия на то, чтобы обеспечить объективность изложения истории Второй мировой войны. В данной работе поставлена цель рассмотреть, как решается задача противостояния фальсификациям в российской историографии последних лет. Выявлены основные направления и содержание критического анализа фральсификации событий.

Ключевые слова: Вторая мировая война, фбальсификация, историографбия, инфборлационное воздействие

Medvedeva L. M. Opposition to falsification of the history of World War II in modern Russian historiography.

The revision of views on the course and results of World War II is a means of ideological struggle and manipulation of public consciousness, which is persistently used in imposing anti-Russian discourse on the international community. Russian scientists are directing efforts to ensure the objectivity of presenting the history of the Second World War. The article is devoted to solving the problem of confronting the falsification of the history of World War II in Russian historiography in recent years. The main directions and content of a critical analysis of falsification of events are revealed.

Key words: World War II, falsification, historiography, informational impact

Для цитирования: Медведева Л. М. Противостояние фальсификации истории Второй мировой войны в современной российской историографии // Ойкумена. Регионоведческие исследования. 2020. № 1. C. 13-19. DOI: 10.24866/1998-6785/2020-1/13-19

For citation: Medvedeva L. M. Opposition to falsification of the history of World War II in modern Russian historiography // Ojkumena. Regional researches. 2020. № 1. P. 13-19. DOI: $10.24866 / 1998-6785 / 2020-1 / 13-19$ 


\section{Антропология и экономика: возможные направления взаимодействия}

11 февраля в Институте экономических исследований ДВО РАН (г. Хабаровск) в рамках серии круглых столов, организуемых редакцией журнала "Ойкумена. Регионоведческие исследования", состоялся научно-методологический семинар "Антропология и экономика: возможные направления взаимодействия". С сообщениями выступили доктор фрилос. наук Л. Е. Бляхер ("Концепция Дж. Скотта как методология исследования социально-экономического ландшафрта Приамурья") и канд. ист. наук Я. А. Барбенко ("Особенности дальневосточного крестьянства в свете концепций "моральной экономики" и "оружия слабых" Дж. Скотта").

Демьяненко А. Н.: Коллеги, приветствую вас на семинаре! Прежде чем слово возьмут докладчики, позволю себе сориентировать нашу работу. Для начала зафиксируем: нас интересует не антропология, представляющая собой конгломерат дисциплин, исследующих поведение человеческих сообществ, а область экономической антропологии, описывающей и объясняющей поведение человеческих сообществ (и экономических агентов) прежде всего в социокультурной среде.

Так как в качестве отправной точки один из наших докладчиков взял концепцию Зомии, то я выкажу некоторые суждения относительно и этой концепции, и возможностей использования подходов к исследованию пространственных социально-экономических систем, сложившихся в экономической антропологии. Отмечу, что и концепт Зомии, и проблемы взаимоотношения приамурского крестьянства с государством в ходе освоения Дальнего Востока не чужды участникам семинара $[5 ; \mathbf{6} ; \mathbf{1 0}]$.

Для меня "Зомия" это не только "крупнейший из сохранившихся на Земле регионов, чьи народы до сих пор не были поглощены национальными государствами" [17, с. 9], но и концепт, который предоставляет а) возможности выявить и описать фракторы формирования пространственных систем вне государственного контроля $[\mathbf{1 7}, \mathbf{c . 5 5 ] ,}$ б) инструментарий исследования экономического поведения, неформальных организаций, функционирующих в специфических природных ландшафртах. Отличительными свойствами пространственных систем типа "Зомии" являются: а) нахождение их вне преде-

(C) Бляхер Л. Е., Барбенко Я. А., Демьяненко А. Н., Журавская Т. Н., Минакир П. А., Рьюова Н. П., 2020

БЛЯХЕР Леонид Ефимович, д-р филос. наук, профессор кафедры философии и культурологии Тихоокеанского государственного университета (г. Хабаровск). E-mail: Leonid743342@mail.ru

БАРБЕНКО Ярослав Александрович, канд. ист. наук, доцент кафедры политологии Дальневосточного федерального университета (2. Владивосток). E-mail: prohist@ya.ru

ДЕМЬЯНЕНКО Александр Николаевич, д-р геогр. наук, руководитель сектора проблем развития и функционирования территориальных экономических систем Института экономических исследований ДВО РАН (г. Хабаровск). E-mail: demyanenko@ecrin.ru

ЖУРАВСКАЯ Татьяна Николаевна, канд. социол. наук, доцент Академического департамента Дальневосточного федерального университета, научный сотрудник Приморской лаборатории экономического развития и сотрудничества Института экономических исследований ДВО РАН (2. Владивосток). E-mail: wellshy@mail.ru

МИНАКИР Павел Александрович, д-р экон. наук, академик РАН, научный руководитель Института экономических исследований ДВО РАН (2. Хабаровск). E-mail: minakir@ecrin.ru

РЫжОВА Наталья Петровна, д-р экон. наук, заведующий Приморской лабораторией экономического развития и сотрудничества Института экономических исследований ДВО РАН (2. Владивосток). E-mail: n.p.ryzhova@gmail.com 
лов государства, большие группы населения уходят от политического влияния государств и в то же время ведут активную и взаимовыгодную торговлю с контрагентами в сопредельных государствах; б) высокий уровень мобильности населения, различного в культурном отношении, сопровождается подвижностью и проницаемостью границ; в) мозаичность и труднодоступность природных ландшафтов, что с разнообразием культур обусловливает форомирование обширного спектра хозяйственных практик, которые следует рассматривать не как архаичные, а как адекватные природным и социальным условиям; г) фрормируемые социальные общности - "не остаточное явление, а сознательный выбор места и образа жизни и социальной структуры для сохранения независимости" [17, с. 32], иначе говоря, мы имеем дело с осознанным выбором стратегии поведения.

Наконец, Зомия характеризуется отсутствием центр-периферийных отношений и сетевой организацией местных сообществ, поэтому здесь, как правило, не следует искать иерархии во внутренней структуре региона. Находящиеся в его пределах сообщества локализуются в пределах тех или иных природных ландшафртов или местностей.

И хотя сам Дж. Скотт неоднократно повторяет, что все приводимые им суждения относительно "Зомии" имеют отношение к историческому периоду, который завершается после Второй мировой войны, тем не менее, сам концепт Зомии остаётся вполне рабочим инструментом анализа.

Во-первых, не все представители общества готовы всецело подчинять поведение, в том числе и в сфере экономики, государственной регламентации. Неформальная экономика при определённых условиях может послужить источником формирования пространственных социально-экономических систем. С этой экономикой можно бороться, но в ходе исследования вполне возможно прийти к заключению, что это вовсе не абсолютное зло.

Во-вторых, существует ряд социальных феноменов (в том числе крестьянство), исследование которых, даже в качестве экономических агентов, не укладывается в рамки мейнстрима современной экономической науки, так как их поведение определяется не только экономическими фракторами, но и культурными. Так как разные культуры фрормируют разные мировоззрения, предполагается множество вариантов восприятия реальности, из которых следует разная логика поведения.

В-третьих, именно "экономическая антропология продолжила заниматься экономическими явлениями в их соџиальной многогранности, то есть экономическим, неотделимым от социального, нормативного, религиозного и т. д." [3, с. 66]. Этот всесторонний культурный подход к изучению экономических явлений долго считался релевантным только в отношении не западных, развивающихся обществ, и лишь с 70-х гг. ХХ в. внимание экономических антропологов переключается с исследования традиционных обществ на современные.

Следовательно, "...существует не одна экономика, а несколько разных экономик" [7, с. 93]. То, что Зомия или точнее зомии - "другое общество", вряд ли требует доказательств. Но тогда следует признать: у этого общества другая экономика. И она требует применения и иного аналитического инструментария, не отрицая при этом тех инструментов традиционного экономического анализа, которые уместны и при исследовании экономик подобных экономике Зомии.

Пожалуйста, Леонид Ефимович, Вам слово.

Бляхер Л. Е.: Спасибо. Способом мыслить научно выступают теоретические модели реальности, построенные на основании более или менее жёстко заданной системы аксиом: только таким способом частный случай может стать закономерностью. Некогда сама система аксиом сложилась на основе более или менее всеобщей интуищии. Но сложившись, укоренилась в реальности, стала единственно возможным способом эту реальность помыслить [19]. Дальнейшее исследование обращено уже не на саму реальность, а на сложившуюся систему категорий, которая практически заслоняет реальность от взгляда исследователя, да и обывателя. Сложившийся во второй половине XIX столетия способ мыслить общество, в том числе его хозяйственную составляющую, сохраняется до настоящего времени [14]. 
Описания быта и хозяйства экзотических племён, возникшие в трудах этнографов, долгое время существовали обособленно от экономической теории: это были описания другой реальности. В рамках господствующих представлений эта (архаическая, примитивная) реальность и фрорма хозяйственной деятельности должна была перейти к "нормальным формам". Однако локальные и экзотические хозяйственные системы порой уничтожались вместе с их носителями, а их переход к нормальной экономике был крайне редким. Да и сама "ненормальность" оказалась распространена гораздо шире, чем представлялось первоначально: в трудах Э. де Сото и Г. Мюрдаля [16] описывались уже не экзотические африканские или полинезийские хозяйственные системы, но хозяйственные системы Латинской Америки. Для описания подобных систем рождается термин "неформальная экономика", очень неконкретный, по сути, им обозначали всё, что не вписывалось в экономический мейнстрим, но даже подобная фриксация значима, она свидетельствует, что в хозяйственной жизни накапливаются фракты, которые не могут быть обозначены и исследованы в рамках господствующей теории. Первые исследования в этой области все же относили неформальную экономику (моральную эксполярную $[8$, с. 91-192]) к перифрерийным явлениям, которым противостоит основная, нормальная хозяйственная система, описываемая экономической наукой. Постепенно трактовка неформальности оказывается иной: в рамках неоинституционализма формальные институты становятся одним из частных случаев неформальности [12], сама возможность их существования зависит от того, в какую неформальную среду они погружены.

Потребность в новом языке описания, созданном не на основе европейской матрицы XIX столетия, ощущается всё более остро, особую роль приобретают субдисциплины с предикатом "экономическая" (экономическая социология, экономическая география и т. д.): они позволяют существенно расширить число теоретических моделей описания хозяйственных систем, позволяют в рамках научного знания обозначить и описать фрактографию, ускользающую от взгляда экономиста. Особенно значимой в этом плане представляется экономическая антропология. Антропология радикально меняет исследовательскую позицию - точкой отсчёта становится деятельность человека и соразмерных ему институциональных систем. Здесь государство из сверхинститута превращается в одну из сторон взаимодействия, причём далеко не всегда определяющую.

Однако антропологические исследования достаточно редко "поднимаются" до обобщений [9]. Тем большую ценность приобретают работы, в которых это происходит. В число подобных входят исследования Джеймса Скотта 80-х - 90-х гг. XX в. По существу, описанный им мир "Зомии" выступает примером, лабораторией исследования общества, в том числе его хозяйственного уклада, протекающего без участия государства [22]. Первым и существенным отличием "модели" Скотта от "классических" описаний является отсутствие сверхинститута государства и шире, политической власти, детерминирующей протекание всех иных социально-экономических процессов на данной территории и в данном социуме. На их место выдвигается принцип эгалитаризма (хозяйственного и властного); конкуренция - один из базовых френоменов экономического описания, сменяется здесь на солидарность, подавляющее преимущество сотрудничества над конкуренцией. Меняется и характер рациональности: Скотт убедительно показывает, что поведение агентов исследуемого им безгосударственного социума есть не отсутствие рациональности, а рациональность. Бюрократическому (всеобщему, научному и т. д.) знанию, предполагающему выделенную когорту экспертов, противопоставляется "метис" - знание того, как делается дело в этом месте и в это время [21]. Это тоже экспертное знание. Но форма его существования и бытования иная. Достаточно много уделяет внимания Дж. Скотт и описанию форм противодействия такого общества попыткам внешних политических сил (с благими или с неблагими целями) заставить Зомию жить по бюрократическим правилам [11]. Обозначаются и условия, при которых такое общество возможно, это относительная труднодоступность ландшафрта: Зомия - страна горцев. Отсутствие особенных выгод для государства от контроля над данной территорией или наличие огромных затрат для такого контроля. 
Последнее и представляется особенно значимым при описании социума и хозяйства Приамурья: удалённость от центра, слаборазвитая транспортная система и относительная редкость населения приводят к тому, что реальный контроль государство осуществляет только в нескольких крупных городах региона. Остальная его часть остаётся за пределами статистики, да и за пределами описания. Более того, наличие такой, слабо контролируемой периферии, которая к тому же воспринимается в качестве "пустой" или "деградирующей", создаёт дополнительные возможности для ухода от государственного контроля и жителям крупных городов региона.

За советские годы сложилось два типа пространства применительно к нашему региону: пустое пространство, где ничего нет - нет знаков освоенности, которые мы можем считать. Это пространство традиционных типов хозяйственной деятельности: оленеводства, рыболовства и т. п. Мы можем под определённым углом говорить об этой экономике, но на деле не существует знаков, которые мы могли бы считывать. Затем освоенное пространство, то есть пространство, обладающее чётко выраженными индустриальными знаками, которые мы считываем как "освоение". Это завод, это город, это больница, это дом культуры. За постсоветские годы появился третий тип пространства - брошенное пространство; оно пустое потому, что оттуда ушли люди. Но насколько оно пустое - это дискуссионный вопрос: по корпусу интервью, которые мы собирали с 1996 г., это пространство необычайно высокой хозяйственной активности. Люди туда уходят, уклоняясь от налогов, от государственного участия и т. д. Итак, в брошенном пространстве знаки освоенности исчезли или деградировали, но какая хозяйственная активность там происходит? Например, в брошенных деревнях возникают теневые фрермы, как в Николаевском районе.

Ситуация начинает меняться в связи с "поворотом на Восток", с последними государственными активностями, реосвоением, когда мы опять создаём на опустевшей, брошенной, территории знаки, которые мы можем читать как "знаки освоения": заводы в Амурской области, создание ТОРов, строительство в Амурске гигантского комбината. В ходе экспедиции, проведённой летом 2019 г., мы встретили людей, которые вербализировали и реализовали момент, описанный Скоттом. Мы встретили этих людей в Хабаровском крае и в Иркутской области; это вполне социально адаптированные люди, мы нашли усадьбы площадью до гектара, с большими посёлками. Появляется моё пространство как тип: пустое пространство, освоенное пространство, брошенное пространство "моим пространством" не является. "Моё пространство" - это способ освоения территории, причём это пространство защищено расстоянием, до ленских усадеб надо 6 часов на лодке добираться, а хабаровские поселения находятся на охраняемой территории, это заказник, то есть люди сознательно дистанцируются от этого мира - возникает новый тип освоения, который можно назвать криминалом, но, строго говоря, вся Зомия - криминал.

Попытка расширения официального дискурса на хозяйственную деятельность, которая развивалась в брошенном пространстве позволяет говорить о том, что концепции о "местном знании", метисе, и "теоретическом знании" могут быть использованы и здесь. Почему Дальний Восток, почему это специфично здесь? По очень простой причине: мы уже говорили об издержках контроля, можно говорить об издержках пространства, Когда есть тип освоения, не свойственный территории, типу социального ландшафта. Не столько важно, что эти люди могут быть названы преступниками, сколько важно, что возникает новый социальный ландшафот. В данном случае модель Скотта, то есть рациональность, не вписывающаяся в рациональность модерна, вполне рациональна для нашего региона, причём по вполне банальной причине: завод в малонаселённой континентальной территории имеет весьма ограниченный әкономический смысл. Из әтой рациональности понятен бурный отток населения, который связан не с трудными экономическими условиями, не с плохой экологией и не с маленькой зарплатой и недостатком льгот, но с неправильным использованием ландшафта.

Подобная (конечно, очень краткая) картина ландшафта Приамурья и, ещё больше, ландшафта остальных автономных частей административного образования "Дальний Восток" делает возможным распространение на исследование и описание местного сообщества и иных положений Дж. Скотта. Тер- 
ритории Востока России последние века никак не могут быть обозначены в качестве безгосударственного образования. Однако функция государства как регулирующего и детерминирующего все и вся сверхинститута, производящего бюрократический порядок [4], представляется достаточно сомнительной. Как и на любой периферии, государство здесь слабее, представляет собой не столько всеобъемлющую силу, сколько рыцарский замок, из которого временами отряды выезжают за данью и для приведения к покорности особо ретивых крестьян. Однако между походами крестьяне продолжают свою неторопливую и безгосударственную жизнь, построенную по неизвестным государству законам. И здесь работы Скотта позволяют эту жизнь понять, описать и, быть может, найти возможности согласовать её с самим фрактом существования государства и экономики.

Рыжова Н. П.: Согласна с тем, что последние изменения в российской экономической политике, и прежде всего в отношении Дальнего Востока, требуют дополнительных инструментов, других языков описания. Если экономическая логика программ, проектов, институциональных инициатив, направленных на развитие региона, завуалирована или вовсе отсутствует, то полезны подходы, наработанные в антропологии или социологии и связанные с изучением дискурсов, ритуалов, процедур и т. п. Остаётся за кадром - автор провёл исследование и сделал вывод, что исследовательская оптика, предложенная Скоттом, "хорошо подходит" для объяснения его эмпирического материала? Или он берет теоретические идеи и пытается сформировать некую методологию и приложить её к эмпирике Дальнего Востока? Если автор пытается разработать некоторую методологию, то есть вначале адаптировать теоретические идеи, а потом их "приложить" к ещё не собранной этнографическими методами эмпирике, то это вдвойне смущает. Ведь антропологи всегда начинают с поля и в основном стремятся опровергнуть, изменить существовавшую до них дискуссию. Тогда должны бы появиться такие заявления, как "в отличие от Дж. Скотта, мы...". На то, что автор пошёл именно по этому пути и пытается обосновать методологию, указывает не только начало текста, но и отсылки к трём разным работам Скотта ("Благими намерениями...", "Сопротивление слабых" и "Зомия").

Бляхер Л. Е.: Весь пафос моего выступления сводился к тому, что сходные по структурным параметрам, а отнюдь не по природным, не по климату и так далее, сходные с Зомией пограничные условия возникают в Северной Евразии, в границах Дальнего Востока. Это традиционные хозяйства, недрормальная экономика, которая сложилась в 90-е гг., которая параллельно существовала как экономика самообеспечения в советский период. Существует некая структурная специфика, связанная с пространственной организацией, с плотностью населения, со спецификой взаимодействия с государством, себестоимостью государственного контроля и т. д. и т. п., которая определяет некоторый тип хозяйствования. Как я пытался сказать, описанные Скоттом структурные характеристики могут быть выделены и описаны применительно к Дальнему Востоку, и в результате такой операции мы получаем картинку, которая позволяет включить некую иную оптику по сравнению с классической.

Демьяненко А. Н.: Скотт делает упор на принципиальный отказ людей от государственного контроля, формирование ими самоорганизующихся систем, которые действительно не являются натуральными, они взаимодействуют с равнинными государствами. Итак, дело в принципиальном отказе от государственного контроля.

Минакир П. А.: Если весь пафрос заключается в том, что мы обсуждаем некие общества, сознательно локализующиеся вне зоны госконтроля - это одно. Если мы говорим о том, о чём на самом деле говорит вся каноническая экономическая антропология, о наличии таких сообществ, экономика которых локализована по отношению к товарной мейстримной экономике, то что ближе нам? Мы говорим о феномене антигосударственности или о феномене экономики антиэкономтеоретической?

Бляхер Л. Е.: Падрос Скотта всё-таки не экономический, он не говорит, что это экономика иная качественно. Он говорит, что существует сверхинститут, легитимирующий все иные институты, но существуют общества, которые этого не хотят. Антропологический подход заключается не в выявлении количества занятых определённым образом, а в выявлении самих практик, спосо- 
бов действия. Такой подход может быть использован как средство компроментации статистических данных, когда известно, что данная система действия проявляется таким-то образом, а если не проявляется, значит, она не существует.

Минакир П. А.: Каноническая теория, описывая т. н. общий массив экономической жизни, отвлекаясь от особенностей, обнаруживает некую абстрактную общность, абстрактные магистрали движения экономики, то әкономическая антропология занимается особенностями, которые сознательно не рассматриваются мейнстримом, потому что они настолько малы, что не могут возмущать общую магистраль. Но вместе с тем они существуют, и, поскольку в мире всё взаимосвязано, совершенно неслучайно остатки этого архаичного, с точки зрения мейнстрима архаичного, хозяйства, социальной организации и т. д. тем не менее рассматриваются где-то как атавизм в традиционных обществах, в традиционных экономиках, а где-то, может быть, и проникают из этих особенностей в ткань экономики мейнстрима. Эти влияния, пусть они незначительны по объёму, но они очевидны, во всяком случае, с точки зрения функционирования самого мейнстрима и с точки зрения фрункционирования экономики как отношения людей, модифицируют эти отношения, пусть в какой-то небольшой части. В чём я здесь усматриваю смысл: мейнстримом до недавнего времени являлась т. н. глобализация, а глобализация предусматривает, что по всем этим особенностям, частностям должен каток пройтись и от них ничего не должно было остаться с теоретической точки зрения. Вот эти устойчивые особенности, восстанавливающиеся связи, которые то ли противостоят, то ли ограничивают, то ли модифицируют тенденции самого глобализма. С этой точки зрения тут надо копать дальше.

Демьяненко А. Н.: Спасибо, коллеги, приступим к следующему докладу.

Барбенко Я. А.: Спасибо, Александр Николаевич. Начну с методологического момента: определимся с характеристиками объекта исследования, которые для нас имеют значение. В качестве исходной точки возьму подход Т. Шанина, очень близкого в своей интерпретации к взглядам Скотта. Так Шанин определяет крестьян как "мелких сельскохозяйственных производителей, которые, используя простой инвентарь и труд членов своей семьи, работают - прямо или косвенно - на удовлетворение своих собственных потребительских нужд и выполнение обязательств по отношению к обладателям политической и экономической власти" [8, с. 11]; он уточняет эти положения следующими чертами: семейное хозяйство, хозяйствование на земле, деревенская культура и низшее положение в системах социального господства [8, c. 11]. Именно последний пункт о низшем положении крестьян имеет прямое отношение к интерпретации Скотта; в цитируемых ниже его текстах 70-х и 80-х гг. об этом напрямую не говорится, однако позднейшие работы ("Благими намерениями государства", 1998 и "Искусство быть неподвластным", 2009) исходят именно из такого положения.

Скотт формулирует следующее определение "оружия слабых" как стратегии крестьянского поведения: "любое действие члена класса, которое предназначено либо для смягчения, либо для отклонения требований (ренты, налогов, почтения), предъявленных этому классу вышестоящими классами (арендодателями, государством, владельцами машин, ростовщиками) или для выдвижения собственных требований (на работу, землю, благотворительность, уважение) по отношению к этим высшим классам" [20, p. 36], и далее: "такое сопротивление фрактически всегда является уловкой, используемой более слабой стороной, чтобы пресечь требования институционального или классового противника, который доминирует в публичном осуществлении власти" [20, p. 52] (перевод мой). Кроме того, автор указывает на такие формы доминирования над крестьянами, как материальное господство (способность изъятия материальных средств), отрицание статуса (посягательства на достоинство), идеологическое господство (способность оправдать господствующий статус) $[20$, р. 55-56].

Ещё одной значимой характеристикой крестьянства является "моральная экономика", такой способ ведения хозяйства и вообще способ организации общественной жизни, который гарантирует выживание, в том числе путём отказа от хозяйственного риска [8, с. 29-31], что делает неэффективным 
традиционный экономический анализ деятельности крестьян, построенный на идее предпринимательского интереса. Сам Скотт прямо включает русское крестьянство в культуру "этики выживания" [8, с. 29], что в общем не вызывает возражений. Содержание этики выживания: а) уровень потребления как точка отсчёта любых хозяйственных действий; б) принятие инноваций при гарантии сохранения уровня потребления; в) использование внешних источников как средства против голода; г) моральная солидарность на фоне опасности голода (масштабируется от селения до государства) [8, с. 30-32].

Сведём все указанные черты крестьянства в одну схему: 1) "оружие слабы $x^{\prime \prime}:$ a) низшее положение в обществе; б) источник материальных средств для элиты; в) ущемление в правах; 2) "лоральная эконолика": а) избегание голода как фрилософия хозяйства; б) отрицание хозяйственного риска; в) моральная солидарность как фрилософия общественной жизни.

Особенности жизни дореволющионного дальневосточного крестьянства делали из него самобытный субъект и влияли на его внутренние характеристики. Эти особые условия могут быть сорормулированы так: а) военно-политический характер колонизации Приамурья; б) многоземелье и отсутствующий на практике контроль за распределением угодий; в) присутствие в крае не просто инокультурного, но иноцивилизационного населения с особым отношением к жизни, что вело к невозможности его прямого (или даже косвенного, но эфффективного) контроля со стороны государственной власти. Какие следствия это имело для приамурского крестьянства? Обобщённо: форомируется крестьянство, по некоторым своим функциям близкое функциям казачества. Это фонкция политическая, которая в первую очередь связана с обеспечением контроля над территорией: только те территории государственная власть могла считать подконтрольными, которые занимало русское крестьянство (казачество и военные в смысле контролируемой площади не могут сравниться с крестьянством). Территории, контролируемые аборигенами, находились в "серой зоне", а территории, контролируемые китайцами, вообще могли оказаться под символическим суверенитетом цинской администрации.

Что же представляло собой приамурское крестьянство, какими оно обладало чертами, отличающими его от крестьянства более западных районов страны, особенно от крестьян её европейской части, мест выхода переселенцев (на контрасте с образом крестьянства, рисуемым Дж. Скоттом в его теории крестьянства)? Во-первых, дальневосточное крестьянство не было беднейшим слоем населения региона (были манзы, пришлые корейџы, аборигены). Во-вторых, дальневосточное крестьянство не было бесправнейшим слоем населения региона (Переселенческое управление очень заботилось и следило за обеспечением прав переселенцев; право бесплатного пользования государственной землёй было, вероятно, монополией крестьянства). В-третьих, дальневосточное крестьянство не было многочисленнейшим слоем населения региона, крестьян (даже среди русского населения) было мало, их ценили выше, чем в более западных регионах. В-четвёртых, дальневосточное крестьянство было опорой русского присутствия в регионе вместе с казачеством, армией и орлотом.

Определяя отношение дореволюционного дальневосточного крестьянства к критерию "оружие слабых", можно указать на то, что практически все группы крестьян-переселенцев (старожилы, новосёлы, русскоподданные корейцы) к политически слабым отнесены быть не могут, как было отмечено выше; разве что старообрядцы подвергались некоторым ущемлениям.

Однако дальневосточное крестьянство есть часть крестьянского мира России, культура которого обладала чертами, выделенными Скоттом. К таким традиционным чертам, которые дальневосточное крестьянство сохранило, можно отнести "моральную экономику". По критерию моральной экономики можно отметить почти полное совпадение характеристик приамурского крестьянства с его содержанием. Так, на начальных этапах крестьянской колонизации, в 60-е и 70-е гг. XIX в., крестьяне испытывали голодовки и активно обращались к администрации за материальной помощью; с 90-х гг. XIX в. войска закупали зерно у местных крестьян, но при этом важно помнить, что для армии эта история была в чём-то отягощающая, поскольку местное зерно было худшего качества, зато для крестьян-продавцов это была возможность развития. Получается, что снабжение войск из местных ресурсов было соци- 
альной фрункцией государства в отношении населения. Наконец, отношение к хозяйственному риску у православных крестьян было, по крайней мере, по сравнению со старообрядцами, отрицательным, чему имеются примеры [1].

Что касается оружия слабых как крестьянской позиции в отношении государства, то она в практике дальневосточных крестьян есть следствие a) политики нормализации (относительно других регионов страны) жизни на Дальнем Востоке, осуществлявшейся в советское время и б) универсализации системы управления ещё с начала XX в. в Российской империи: уже с рубежа XIX и XX вв. Приамурье становится всё более интегрированной и всё менее экзотичной страной. Это хорошо видно на примере развития переселенческого законодательства, специализированного в середине XIX и относительно стандартизированного уже в начале XX в. [2, с. 13-14]. Но до революции почва для нормализации крестьянства, как кажется, только готовилась. Революция в жизни крестьянства произошла в 20-е гг., когда всеэмансипирующие советская власть и партия большевиков перестали ценить крестьян вообще, большая часть которых становится классовым врагом нового государства. Таким образом, в 20-е гг. и далее потенции изменения, заложенные ещё в дореволюционное время, реализовывались в гипертрофированной форме.

Чем труднее и неопределённее было присутствие русских в регионе, тем выше и специфичнее для крестьянского сословия в России было положение дальневосточного крестьянства. По мере развития региона главная фрункция крестьянства ослабевала, что вело к падению статуса дальневосточного крестьянства, выразившись в явной форме в раннее советское время. Таким образом, можно отметить, что политический статус крестьян-переселениев колпенсировал особенности традиционного для крестьянства эконолического поведения: переселенцы целыми семьями пускались в трансконтинентальное или океаническое путешествие на другой конец света, рассчитывая на существенное изменение уровня жизни, которое было функцией их привилегированного статуса. Центральное же правительство и местная администрация получали возможность использования крестьян как средства проведения государственной политики в Приамурье.

Журавская Т. Н.: Вы указываете на особенности жизни крестьян на Дальнем Востоке, которые повлияли на его самобытность и внутренние характеристики. Однако не очень понятно, от кого (от какой группы? сообщества?) Вы выстраиваете описание это самобытности - от западного крестьянства или модели, предложенной Дж. Скоттом? Или Вы предполагаете, что крестьянство, проживающее в западной части России, и есть то самое, модельное крестьянство, описанное Скоттом?

Демьяненко А. Н.: И то, что касается моральной экономики по Скотту - это касается горцев или касается равнинных крестьян?

Барбенко Я. А.: Познавательный аппарат, который я использую, относится к трудам до "Зомии", поэтому, возможно, речь идёт о равнинных крестьянах, хотя автор не делал тогда акцента, говоря о крестьянах вообще. Сопоставление концепций "моральной экономики" и "оружия слабых" позволяет нам однозначно зафиксировать особенности дальневосточного крестьянства и на фоне русского крестьянства, и на фоне теории: Скотт провоцирует нас к тому, чтобы увидеть дальневосточное крестьянство в таком ракурсе: не угнетаемое большинство, а привилегированное меньшинство.

Минакир П. А.: То есть Скотт подразумевает под крестьянством одно сочетание признаков, мы смотрим на определённый исторический период в конкретной обстановке и видим другое сочетание признаков? Нормально Скотт ведь не изучал Дальний Восток.

Барбенко Я. А.: Да, но во всех случаях мы говорим "крестьянство", в нашем же случае, дальневосточном, мы имеем "крестьянство+".

Минакир П. А.: Вся история это описание особенностей. Нас интересуют тренды, некие общие закономерности, они или есть, или их нет, или мы их не понимаем.

Барбенко Я. А.: Если бы не государство и его усилия по привлечению и транспортировке населения, гражданские жители до Дальнего Востока практически не добирались бы. Большая часть переселенцев оседала на Урале и в Западной Сибири, ни один нормальный крестьянин, руководствующийся своей крестьянской рациональностью, в такое мероприятие ни себя, ни своё 
хозяйство не вверг бы. Отсюда вывод: особый политический статус крестьянства, те самые льготы, которые были предоставлены крестьянам-переселенцам, компенсировали особенности экономического поведения данного актора. Крестьяне не были "слабыми" в категориях Скотта, они были "сильными", и это как бы перечёркивало сознание "моральной экономики" и переносило их на Дальний Восток. Многие хозяйства разорялись, что подтверждало минусы переселения.

Минакир П. А.: Для того, чтобы прийти к такому выводу, можно опереться на более близкие к нам ситуации с той же самой мотивационной платформой: индустриальное переселение на Дальний Восток, когда нужно было строить заводы, нужно было добывать ресурсы - не было рабочих рук, не было населения. Оставим в стороне ГУЛАГ, ведь было переселение, которое происходило не только в 30-е гг. и не только в первые послевоенные годы, но и в 70-е гг., в первой половине 80-х; оно ведь почему происходило? Оно происходило благодаря тому, что государство вело целенаправленную политику, предоставляя ту самую силу переселенцам в виде различных льгот, особых условий.

Пока что мы говорим о частных случаях и не можем методологически свести даже два направления переселения: аграрное и индустриальное. Да, Скотт показывает, каким образом происходит самоорганизация общества, но общества или групп внутри общества? Если мы, говоря об обществе, берём одну группу, да ещё и локализованную в совершенно особых условиях, мы должны иметь возможность распространить её частный опыт организации и распространить на общество в целом - пока для нас это проблема. Мы избрали тематику нашего разговора как некое обоснование методологии экономического анализа, а методология предусматривает некие канонические основы процесса, но их пока нет, мы остаёмся в состоянии неведения. И это при обилии упоминаний термина "экономическая антропология" в экономической науке и при востребованности этой тематики и в отечественной, и ещё более в зарубежной науке.

Демьяненко А. Н.: Пока мы находимся в состоянии тотального описания.

Завершая наше обсуждение достаточно экзотичной темы, хочу привести две цитаты, первая из Н. Флигстина: "Большинство экономистов игнорирует или попросту не знают о том, как не экономисты размышляют об экономических процессах" [18, с. 31]. Добавим от себя: и тому есть причины, в том числе и те, которые связаны с дисциплинарными границами. Вторая из П. Бурдье: "У каждой дисциплины есть своя область "само собой разумеющегося", свои очевидности, и точно так же, как могут навести на мысль контакты разных цивилизаций ..., очень интересны и контакты разных дисциплин, иногда даже в их варваризмах, поскольку они заставляют поставить под вопрос неявные посылки, которые, в конечном счете, забываешь в силу общего размытого консенсуса ..." [7, с. 97].

Надеюсь, что, несмотря на неизбежные "варваризмы", контакт представителей разных дисциплин был небесполезен для участников семинара.

\section{Литература}

1. Барбенко Я. А. Подход к изучению информационного освоения региона (на опыте крестьян-переселенцев на Дальний Восток) // Этномиграционные процессы на Дальнем Востоке: Мат-лы Всерос. науч.-практич. конф. с междунар. участием (27-28 октября 2017). Хабаровск: Изд-во ДВГУПС, 2017. С. 28-32.

2. Барбенко Я. А. Динамика переселенческого законодательства в Приамурском крае во второй половине XIX в. // Известия Восточного института. 2018. № 4. С. 6-18. DOI: $10.24866 / 2542-1611 / 2018-4 / 6-18$

3. Бёгельсдейк Ш., Маселанд Р. Культура в экономической науке: история, методологические рассуждения и области практического применения в современности. М.; СПб.: Изд-во Ин-та Гайдара; Изд-во "Междунар. отн."; Фак-т свободных наук и искусств СПбГУ, 2016. 464 с.

4. Бляхер Л. Е. Искусство неуправляемой жизни. Дальний Восток. М.: Европа, 2014. $208 \mathrm{c}$. 
5. Бляхер Л. Е. Быть неподвластным: феномен самоорганизации Приамурского крестьянства в конце XIX - начале XX вв. // Регионалистика. 2017. Т. 4. № 6. С. 5-16. DOI: $10.14530 /$ reg.2017.6

6. Бляхер Л. Е., Бляхер М. Л. Зомия на Амуре, или государственный порядок вне государства // Полития. 2018. № 1. C. 148-171. DOI: 10.30570/2078-5089-2018-88$1-148-171$

7. Бурдье П. Экономическая антропология: курс лекций в Коллеж де Франс (1992-1993). М.: Изд. дом. Дело, 2019. 407 с.

8. Великий незнакомец: крестьяне и фрермеры в современном мире. М.: Изд. группа "Прогресс"-"Прогресс-Академия", 1992. 432 с.

9. Гирц К. Базарная экономика: информация и поиск в крестьянском маркетинге // Экономическая социология. 2009. Т. 10, № 2. С. 54-61.

10. Демьяненко А. Н. Местное самоуправление на Дальнем Востоке: опыт 20-х годов // Известия Русского географического общества. 1992. Т. 124. Вып. 1. С. 91-98.

11. Никулин А. Искусство господства и сопротивления в концепции Джеймса Скотта // Отечественные записки. 2003, № 3. С. 36-51.

12. Норт Д. К., У оллис Дж., Вайнгаст Б. Насилие и сощиальные порядки. Концептуальные рамки для интерпретации письменной истории человечества. М.: Издательство Института Гайдара, 2011. 480 c.

13. Поланьи К. Великая трансформация: политические и әкономические истоки нашего времени. СПб.: Алетейя, 2014. 311 с.

14. Поппер К. Миф концептуального каркаса // Поппер К. Логика и рост научного знания. М.: Прогресс, 1983. С. 134-156.

15. Семинар 1. Обсуждение монографии: Скотт Дж. Моральная экономика крестьянства. Нью-Хэвн; Лондон, 1976 // Современное крестьяноведение и аграрная история в ХХ веке. М.: РОССПЭН, 2015. 742 с. С. 29-45.

16. Сото Э. де. Иной путь: Невидимая революция в третьем мире / Пер. с англ. Б. Пинскера. М.: Catallaxy, 1995. 320 с.

17. Скотт Дж. С. Искусство быть неподвластными: Анархическая история высокогорной Юго-Восточной Азии. М.: Новое издательство, 2017. 568 с.

18. Флигстин Н. Архитектура рынков: экономическая социология капиталистических обществ XXI века. М.: Изд. дом Высшей школы экономики, 2013. 392 с.

19. Kuhn T. The Structure of Scientific Revolutions. Chicago: University of Chicago Press, $1962.310 \mathrm{p}$.

20. Scott J. C. Everyday Forms Of Resistance // The Copenhagen journal of Asian studies. No. 4, 1989. P. 33-62.

21. Scott J. C. Seeing Like a State: How Certain Schemes to Improve the Human Condition Have Failed. New Haven: Yale University Press.1998. 432 p.

22. Scott J. C. The Art of Not Being Governed: An Anarchist History of Upland Southeast Asia. New Haven: Yale University Press, 2009. 462 p.

\section{Транслитерация по ГОСТ 7.79-2000 Система Б}

1. Barbenko Ya. A. Podkhod k izucheniyu informatsionnogo osvoeniya regiona (na opyte krest'yan-pereselentsev na Dal'nij Vostok) // EHtnomigratsionnye protsessy na Dal'nem Vostoke: Mat-ly Vseros. nauch.-praktich. konf. s mezhdunar. uchastiem (27-28 oktyabrya 2017). KHabarovsk: Izd-vo DVGUPS, 2017. S. 28-32.

2. Barbenko Ya. A. Dinamika pereselencheskogo zakonodatel'stva v Priamurskom krae vo vtoroj polovine XIX v. // Izvestiya Vostochnogo instituta. 2018. № 4. S. 6-18. DOI: $10.24866 / 2542-1611 / 2018-4 / 6-18$

3. Byogel'sdejk Sh., Maseland R. Kul'tura v ehkonomicheskoj nauke: istoriya, metodologicheskie rassuzhdeniya i oblasti prakticheskogo primeneniya v sovremennosti. M.; SPb.: Izd-vo In-ta Gajdara; Izd-vo "Mezhdunar. otn."; Fak-t svobodnykh nauk i iskusstv SPbGU, 2016. $464 \mathrm{~s}$.

4. Blyakher L. E. Iskusstvo neupravlyaemoj zhizni. Dal'nij Vostok. M.: Evropa, 2014. $208 \mathrm{~s}$.

5. Blyakher L. E. Byt' nepodvlastnym: fenomen samoorganizatsii Priamurskogo krest'yanstva v kontse XIX - nachale XX vv. // Regionalistika. 2017. T. 4. № 6. S. 5-16. DOI: $10.14530 / \mathrm{reg} .2017 .6$

6. Blyakher L. E., Blyakher M. L. Zomiya na Amure, ili gosudarstvennyj poryadok vne gosudarstva // Politiya. 2018. № 1. S. 148-171. DOI: 10.30570/2078-5089-2018-88-1148-171

7. Burd'e P. Ehkonomicheskaya antropologiya: kurs lektsij v Kollezh de Frans (1992-1993). M.: Izd. dom. Delo, 2019. 407 s.

8. Velikij neznakomets: krest'yane i fermery v sovremennom mire. M.: Izd. gruppa "Progress"-"Progress-Akademiya", 1992. 432 s.

9. Girts K. Bazarnaya ehkonomika: informatsiya i poisk v krest'yanskom marketinge // Ehkonomicheskaya sotsiologiya. 2009. T. 10, № 2. S. 54-61. 
10. Dem'yanenko A. N. Mestnoe samoupravlenie na Dal'nem Vostoke: opyt 20-kh godov // Izvestiya Russkogo geograficheskogo obshhestva. 1992. T. 124. Vyp. 1. S. 91-98.

11. Nikulin A. Iskusstvo gospodstva i soprotivleniya v kontseptsii Dzhejmsa Skotta // Otechestvennye zapiski. 2003, № 3. S. 36-51.

12. Nort D. K., Uollis Dzh., Vajngast B. Nasilie i sotsial'nye poryadki. Kontseptual'nye ramki dlya interpretatsii pis'mennoj istorii chelovechestva. M.: Izdatel'stvo Instituta Gajdara, 2011. $480 \mathrm{~s}$.

13. Polan'i K. Velikaya transformatsiya: politicheskie i ehkonomicheskie istoki nashego vremeni. SPb.: Aletejya, 2014. $311 \mathrm{~s}$.

14. Popper K. Mif kontseptual'nogo karkasa // Popper K. Logika i rost nauchnogo znaniya. M.: Progress, 1983. C. 134-156.

15. Seminar 1. Obsuzhdenie monografii: Skott Dzh. Moral'naya ehkonomika krest'yanstva. N'yu-KHehvn; London, 1976 // Sovremennoe krest'yanovedenie i agrarnaya istoriya v KHKH veke. M.: ROSSPEHN, 2015. 742 s. S. 29-45.

16. Soto Eh. de. Inoj put': Nevidimaya revolyutsiya v tret'em mire / Per. s angl. B. Pinskera. M.: Catallaxy, 1995. $320 \mathrm{~s}$.

17. Skott Dzh. S. Iskusstvo byt' nepodvlastnymi: Anarkhicheskaya istoriya vysokogornoj Yugo-Vostochnoj Azii. M.: Novoe izdatel'stvo, 2017. $568 \mathrm{~s}$.

18. Fligstin N. Arkhitektura rynkov: ehkonomicheskaya sotsiologiya kapitalisticheskikh obshhestv XXI veka. M.: Izd. dom Vysshej shkoly ehkonomiki, 2013. 392 s.

19. Kuhn T. The Structure of Scientific Revolutions. Chicago: University of Chicago Press, $1962.310 \mathrm{p}$.

20. Scott J. C. Everyday Forms Of Resistance // The Copenhagen journal of Asian studies. No. 4, 1989. P. 33-62.

21. Scott J. C. Seeing Like a State: How Certain Schemes to Improve the Human Condition Have Failed. New Haven: Yale University Press.1998. 432 p.

22. Scott J. C. The Art of Not Being Governed: An Anarchist History of Upland Southeast Asia. New Haven: Yale University Press, 2009. 462 p.

Бляхер Л. Е., Барбенко Я. А., Демьяненко А. Н., Журавская Т. Н., Минакир П. А., Рыжова Н. П. Антропология и экономика: возможные направления взаимодействия.

Blyakher L. E., Barbenko Ya. A., Demyanenko A. N., Zhuravskaia T. N., Minakir P. A., Ryzhova N. P. Anthropology and economics: possible areas of cooperation.

Для цитирования: Бляхер Л. Е., Барбенко Я. А., Демьяненко А. Н., Журавская Т. Н., Минакир П. А., Рыжова Н. П. Антропология и экономика: возможные направления взаимодействия // Ойкумена. Регионоведческие исследования. 2020. № 1. С. 20-30. DOI: 10.24866/1998$6785 / 2020-1 / 20-30$

For citation: Blyakher L. E., Barbenko Ya. A., Demyanenko A. N., Zhuravskaia T. N., Minakir P. A., Ryzhova N. P. Anthropology and economics: possible areas of cooperation // Ojkumena. Regional researches. 2020. № 1. P. 20-30. DOI: 10.24866/1998-6785/2020-1/20-30 


\section{Идея о частной собственности и "реальные" захваты земли}

Как связаны захваты зелли и институт частной собственности? Исследователи, отвечающие на этот вопрос, обращаясь к эмпирическим данным американских и австралийских фронтиров, утверждают, что захваты в значительной степени определяли те "правильные" либеральные институты ${ }^{1}$ собственности, которые сложились в этих странах. Если захваты играли такую позитивную роль в одних условиях, могут ли они в других случаях препятствовать фрормированию частной собственности? В № 1 за 2019 г. журнала "Ойкумена" была опубликована работа (Рыжова Н. П., Гузей Я. С., Карбаинов Н. И. "Институт собственности на землю: захваты, "ресурсное изобилие" и особенности инфорсмента на российском Дальнем Востоке"), предлагающая вариант ответа на этот вопрос, исходя из опыта колонизации российского Дальнего Востока. В частности, сделан вывод о том, что хотя частная собственность на ДВ и фборлировалась, но она бьлла культурно специфбичной по сравнению с алериканской или австралийской моделью.

Этот вывод является отправной точкой для данной статьи. Прежде всего отметим, что исследовательский вопрос нашего проекта о связи захватов и института частной собственности был сформулирован исходя из экономической теории прав собственности и так называемой либеральной повестки. Забегая вперед, отметим, что все отношения собственности, в том числе существовавшие в XIX в. в Австралии или существующие сейчас в США, отличаются от идеальных моделей, "списанных" с англосаксонского права. На первый взгляд это означает, что бессмысленно сравнивать социальные отношения, складывающиеся в определенном культурном контексте, с экономико-либеральной идеей о частной собственности. Однако это только на первый взгляд: стремление к имплантации института частной собственности стало одной из навязчивых идей рыночных трансформаций России 1990-х гг., а российскими и не только экономистами написано множество работ, отвечающих на вопрос: "А сложилась ли частная собственность за время трансформаций и, если нет, то почему?".

Если следовать идеям М. Каллона, экономические отношения не просто описываются экономической наукой, но во многом создаются, переформатируются ими [7], "переделывая" таким образом реальность, трансформируя ее под себя. Впрочем, споря с Каллоном, антрополог Д. Миллер [13] утверждает, что рынок "реальный" не подчиняется собственно рыночной модели и находит способы от нее уклониться. Эти аргумент и контраргумент определили основной вопрос данной статьи. Вместо анализа того, как реальные захваты влияют на институт частной собственности, мы пытаемся понять, как сосуществуют идеи о частной собственности и "реальные" захваты. Говоря о сосуществовании и забегая вперед, отметим, что в зависимости от конкретного контекста либерально-экономическая идея могла способствовать переводу за-

1 В данной статье термины "институт собственности" и "отношения собственности" не синонимичны. Употребляя термин "институт" мы делаем отсылку к либерально-экономической идее, модели; а используя термин "отношения собственности", мы говорим о социальных отношениях по поводу объекта собственности.

(C) Рыжсва Н. П., Журавская Т. Н., 2020

РЫжОВА Наталья Петровна, д-р экон. наук, профессор РАН, заведующий Приморской лабораторией Института экономических исследований ДВО РАН (ә. Хабаровск). E-mail: n.p.ryzhova@ gmail.com

ЖУРАВСКАЯ Татьяна Николаевна, канд. социол. наук, научный сотрудник Приморской лаборатории Института экономических исследований ДВО РАН (ә. Хабаровск). E-mail: wellshy@ mail.ru 
хваченных ранее земель в частные владения и приближению этих отношений к идеальной экономической модели; могла вообще остаться "незамеченной" в реальности; реальные захваты могли откорректировать способы воплощения либерально-экономической идеи о собственности в реальности; и многообразие других вариантов.

Из спектра реальных отношений собственности мы выбрали те, в которых, во-первых, присутствует захват земли (то есть владение de facto без оформления de jure), и, во-вторых, те, которые для самих участников этих отношений ближе к либерально-экономической идее. Таковыми являются отношения по поводу земли под личными подворьями в селах, под домами/ дачами в городах и пригородах. Что означает ближе к идее? Владение, использование, управление и другие права из "пучка Оноре" [11], которым активно пользуются и экономисты, и юристы, не являются полной абстракцией для человека, когда речь идет о земле под его домом или о земле, приобретенной, полученной или даже захваченной для строительства такового. Он может представлять разные способы реализации своих прав (это совсем не обязательно государственный фрормальный инфорсмент), однако, скорее всего, готов пользоваться всеми доступными формами для их защиты. Напротив, владение, использование, управление - лишь абстракция для людей, если речь идет о бывшей коллективной земле в постсоветской деревне, распределенной на паи, поскольку крестьяне не имеют реального доступа к "потемкинским" институтам, существующим лишь "на бумаге" [3]. Не будучи связанным с этим "бумажным" институтом, крестьянин редко интересуется объектом права, только если не появляется некто, угрожающий изъятию "бумаги". И земля под домом, и "бумажная" земля - в повседневном восприятии самих собственников - едва ли такая же частная собственность, как земля, находящаяся несколько столетий во владении семьи английского лендлорда. Однако земля под домом российского горожанина в условном множестве отношений собственности все же ближе к "идеальной" частной.

Статья основана на этнографических данных, собранных авторами в 2014-2018 гг. в регионах российского Дальнего Востока: один из авторов дважды в течение месяца проживал в "таежном поселке" (2014 и 2017 гг.), второй является членом кооператива, описанного в случае "Остров". Описание случая "Дальневосточный гектар" предоставлено коллегой авторов К. И. Феоктистовой и основано на опыте регулярного обсуждения прогресса оформления прав членами ее семьи (с 2016 г.). Статья состоит из введения, теоретического и эмпирического разделов, а также обширного заключения, в котором обсуждаются результаты исследования.

\section{"Идеальные" модели и "реальные" отношения}

Экономическая теория прав собственности и либеральная парадигма предписььвает необходимость создания института частной собственности на землю. Предполагается, что только экономика, организованная на свободе контракта и частной собственности, позволяет использовать земельные ресурсы әффективно [2]. Однако антропологи относительно давно - по сравнению с экономистами - начали утверждать, что отношения собственности складываются из сочетаний культурных контекстов, сложившихся социальных отношений и отношений власти [15]. Поскольку культура, социальная структура и организация власти специфичны не только для стран, но и зачастую для отдельных регионов, то сложно даже оценить множественность и многозначность реальных, а не модельных отношений собственности, существующих в современном мире. Эмпирические исследования подтверждают, что даже в западных странах эти отношения разнообразны и далеки от идеальных образцов, создаваемых либеральной парадигмой [14].

Наиболее близок к либеральному "идеалу", описанному в учебниках по теории прав собственности, институт, существующий в англо-саксонской культуре. Однако детальный анализ показывает, что отношения собственности в США или Австралии вовсе не идентичны английским. Например, исторический антрополог Макфарлейн [12] пишет, что система индивидуальной собственности в Англии развивалась в течение столетий благодаря двум особенностям: делению прав собственности при неделимости вещи, а также централизованному феодализму, защищавшему индивидуальные (что важ- 
но - не семейные) права аристократии. Частично эти особенности способствовали складыванию формальных и широко распространенных в мире юридических норм. Однако исторические английские особенности не были повторены ни в одной другой стране мира, и поэтому реальные (а не формально-юридические) английские отношения собственности не были импортированы.

О каких формальных правилах идет речь? Делимость прав ведет к тому, что собственность может быть полной или относительной в зависимости от того, каким "пучком прав" обладает собственник (или держатель). При передаче части прав из пучка (владения, физического пользования материальными объектами, присвоения "плодов", управления и т. п.) субъект становится обладателем относительного права собственности; он остается собственником, даже если отдал все права, при условии, что не произошло отчуждения объекта. И только обладая безусловным правом, собственник может отчуждать (продавать) землю или другие объекты. Эти бборлальные правила активно импортировались.

О каких отношениях собственности, определяемых социальными отношениями и отношениями власти, идет речь? Вся земля в Англии и Уэльсе принадлежит монарху, тогда как собственники имеют безусловное право пользования этой землёй и строениями, которые на ней находятся. Это не означает, что монарх пользуется своим правом, но теоретически земля может быть изъята. Распространенность приобретения британской недвижимости на праваx leasehold (то есть безусловного права пользования недвижимостью на определенный срок) - демонстрирует неимпортируемые английские особенности. И, кстати, эта культурная специфика не приводит к неэффективности использования земли, росту бюрократического аппарата и коррупции (как следствие неочевидности гарантированного информсента прав собственности).

Еще одной культурной особенностью Англии является непрозрачность отношений собственности. В противовес к идеализированным представлениям де Сото, который продвигает реформу регистрации путем организации полного и открытого кадастра, "идеальная" английская модель являет собой прямую противоположность. В нашумевшей книге "Кто владеет Британией и Ирландией" журналист Кевин Кэхил [6] указывает, что государственная структура, ответственная за регистрацию земли в Великобритании, не имеет информации о том, кто владеет около 50 процентами земли, находящимися в частной собственности, поскольку обязательной регистрации подлежат только совершаемые сделки купли-продажи.

Таким образом, выводы антропологов $[9,3,16]$ "неутешительны". Идеальной и универсальной частной собственности, идея о существовании которой присутствует в экономической теории, не существует. Признание множественности и многозначности имеет решающее значение для объяснения того, как работают эти правила в земельных отношениях. Современные отношения собственности, как и все прочие социальные отношения, складывались во многом под влиянием позднесоветского контроля над повседневной жизнью и повседневных форм сопротивления ему, а также в постсоветском контексте очарованности либеральной моделью, моделью рыночного перехода.

\section{Три таких разных случая}

В рамках исследования, по результатам которого подготовлена данная статья, были изучены и описаны более 20 различных случаев (в классическом понимании методологии case-study). Для целей данной статьи отобрано три, никак не связанных между собой. При этом один случай является скорее типичным для России в целом ("Таежный поселок"), другой - типичен именно для локального, южно-дальневосточного контекста ("ДВ-гектар"), наконец, третий случай не типичен ни в российских, ни в дальневосточных масштабах ("Остров"). Причины их отбора представлены в следующем разделе и связаны с обсуждаемым в статье вопросом сосуществования либерально-экономической идеи собственности и реальных отношений собственности.

Прежде чем перейти к описанию и обсуждению представленных этнографических данных, проясним еще раз термин "захват", чтобы избежать неверной трактовки предложенных интерпретаций. В данном тексте авторы не ставят задачу оспаривания принятых юридических норм какого-либо го- 
сударства или правового режима, не спорят и с общепринятыми значениями термина. Вслед за исследователями институционального толка, прежде всего, Э. де Сото [8], изучавшим земельные захваты в Латинской Америке, под "захватом" земли мы понимаем владение (и обладание другими правами собственности, в частности, использование и осуществление псевдорыночной продажи) de facto без оформления прав de jure.

"Таежный поселок". Что такое земельное изобилие современного Дальнего Востока? Описанный ниже случай позволяет схватить проявления изобилия и повседневную работу государства с этим изобилием.

Поселок в Амурской области, о котором идет речь, был основан в конце 1930-х гг. вокруг крупного месторождения. Судьба поселения типична не просто для отделенных территорий Дальнего Востока, но шире - для северных регионов страны. В лучшие годы население достигало несколько десятков тысяч человек, работали кинотеатр, школа, лимонадный цех, подсобное сельское хозяйство, велась заготовка леса, золота и т. д. В 1990-е - "развал" и ожидаемое банкротство основного предприятия, закрытие ОРСа, отток населения, постепенное разрушение инфраструктуры... Сейчас в поселке проживает всего около 1000 человек. Несложно представить преобладающий, и снова - типичный, ландшафрт: "обитаемая" часть стягивается к центру, а окраины "отмирают"; брошенные постройки частично снесены, кое-где остался фондамент, много "пустырей"; некоторые дома заселены не полностью, некоторые и вовсе пустуют, часть используется как хозяйственные постройки (гаражи, сараи, кладовые). Неудивительно, что в условиях изобилия не только земли, но и доступных для использования построек, крайне мало объектов передано в частные руки - преобладает муниципальная собственность. Однако это не означает отсутствия "псевдорыночных" сделок, и, шире, отношений частной собственности. Как правило, земельные участки сами по себе не становятся предметом сделок - людей интересуют, прежде всего, расположенные на них постройки ${ }^{2}$. В поселке существует несколько способов получить желаемое.

Ообиииальная просьба в муниципалитет. Фактически, любой приезжий достаточно быстро получает квартиру или дом с земельным участком от муниципалитета - у администрации в связи с сокращением населения сырормировался достаточный для этих целей фонд. Но таким правом обладают не только новые жители, которых, в последнее время все меньше. Любой житель поселка может обратиться с просьбой улучшить условия проживания. Так, одна из многодетных семей каждые 2-3 года меняет дом и двор для проживания: семья обращается в муниципалитет, где для удовлетворения их просьбы формируется комиссия из числа народных депутатов. Комиссия осматривает дом и выносит заключение о том, что дом требует серьезного ремонта и проживать там небезопасно, после чего семья переезжает в новый дом и начинает использовать новый земельный участок.

Небборлальная договоренность с главой адлинистраиии. Это требуется в двух случаях - если интерес представляет конкретный участок или помещение (как правило, это необходимо для легализации уже состоявшегося захвата) либо при осуществлении "псевдопродажи". Например, один из пенсионеров получил квартиру в районном центре по программе переселения из районов Крайнего Севера. На принадлежащем ему в поселке на правах социального найма участке располагались большой кирпичный коттедж и летняя кухня, баня и ряд других основательных построек. Его участком заинтересовалась одна из семей, проживающая в небольшом старом деревянном доме. Переезжающий в город "владелец" согласился продать участок и постройки, однако для этого необходимо было оформить права собственности (приватизировать). Оказалось, что это лишает его права на получение квартиры по указанной программе. В результате торга цена была снижена более чем в 3 раза, фрактически, уезжающий владелец неформально передавал дом как "строительные материалы". "Покупатель" и "продавец" перед передачей денег вместе обратились к главе администрации, чтобы договориться о том, что покупающая участок семья будет зарегистрирована по нужному адресу.

2 Если дом ни для кого не представляет интереса, то бывшие хозяева просто оставляют его, часто не решая даже формальных вопросов, связанных со снятием с регистрационного учета. 
Нефборлальная договоренность между людьли. Переехать в другой дом можно также по договоренности с тем, кто решил уехать из поселка. Фактически, тот, кто уезжает, просто разрешает кому-то, с кем он в дружеских отношениях, пользоваться домом и участком. При этом ни дом, ни участок не обязательно принадлежат уезжающему на каких-либо формальных условиях. Гипотетически, такой тип договоренности может потребовать в дальнейшем обращения в муниципалитет или к главе администрации.

Захват. Желанный участок земли легко захватить в том случае, если на него никто больше не претендует. Как правило, это придомовая территория или заброшенные постройки плохого качества. Например, две семьи разного поколения жили через двор друг от друга. Спустя некоторое время дом посередине и участок под ним освободились. Семьи соединили свои участки, а пустующий дом заняла третья семья (младшей сестры). Все подворья теперь соединены общими переходами.

Таким образом, практически вся собственность на землю (и дома) не легализована. Хотя люди защищают свой дом, личное имущество, они, как правило, даже не пытаются получить правоустанавливающие документы. Установить, кому и как были переданы права в результате многочисленных трансформаций преимущественно ведомственного советского жилья почти невозможно. Поэтому многие оплачивают счета за электроэнергию по квитанциям, выписанным на бывших владельцев или вовсе на соседний адрес, где может быть вообще уже не быть ни дома, ни хозяев.

"Дальневосточный гектар и освоенные сотки". Мы уже писали ранее о том, как реализуется программа ДВ-гектар [1]. Представленный ниже случай необходим нам для тезиса, развиваемого в данной статье.

И. в 1993 г. купил дом в посёлке Кипарисово-2. К купленному участку поселковый совет выделил стандартный по тем временам участок в 20 соток. Площадь определяли приблизительно: "a то u не мерили, просто послотрели и всё. На участке тогда стоял забор, может, 20 лет до того ешё. Посмотрели на забор, полеряли на глаз, выдали свидетельство о праве собственности". Спустя годы произошли изменения в законодательстве в части необходимости постановки участка на кадастровый учёт. И. тогда этим заниматься не хотелось, потому что он не планировал производить никаких операций со своей дачной недвижимостью. Налог присылали на 20 соток, он исправно его платил.

В 2008 г. семья решила построить новый дом на участке, для чего надо было получить разрешение, то есть оформить документы по новым правилам. Первая попытка закончилась провалом из-за выявленного наложения с соседним участком. Разрешение проблемы - исправление кадастровой ошибки - отложили на 8 лет. Для этого пришлось договориться с соседом о том, что он не претендует на "захваченную" И. полосу. Сосед не был против мирного урегулирования вопроса, хотя и терял небольшой кусок земли.

Вторая конфоиктная ситуация закончилась иначе. Другой сосед И., который делил с ним двухэтажный дом и использовал участок в рамках договора аренды, сообщил, что кто-то оформил "гектар" и запрещает ему сажать огород. Конфликт углублялся: "Нарисовались гектаристы зилой, и тут же случился пожар, причёл поджог". В результате сгорел дом на двух хозяев, соответственно, и половина И.: "20 лет дол стоял, а тут вдруг сгорел. На участок они сейчас свозят строительный мусор, что категорически запрещено. И бурьян с человеческий рост, который будет польхать весной. Дальше салое интересное. Начинает меня донилать зелельный инспектор, который говорит о тол, что 27 сентября 2018 года произвёл осмотр участка и сделал заключение, что тот в запущеннол состоянии. А я дулаю, где он тал был? Я тал был 27 сентября, строил дол, сажал огород: тыкву, свеклу. У него такая образеология в преалбуле, я её сльшал в диалоге с АБ". (АБ - гражданин, оформивший участок по программе "ДВ-гектар".) "Такое ошущение, что они кореша. Всё это писано со слов, его тал не было". 26 ноября 2018 г. состоялось судебное слушание, где И. признали виновным в совершении административного правонарушения, предусмотренного ст. 7.1 КоАП РФ, - "самовольное занятие части земельного участка, примыкающего по северной меже".

"Остров". Несмотря на изобилие земли на Дальнем Востоке, строительство частных домов развивается очень медленными темпами. Землю сложно 
"захватить" (легализация нового - не советского - захвата возможна для строительной компании, но почти невозможна для частного лица). Землю почти невозможно получить "просто так" - даже такая льготная категория граждан, как многодетные семьи годами ожидают очереди и зачастую остаются без земли. Землю сложно купить - процедуры непрозрачны, а цены участков превышают возможности большинства потенциальных покупателей. В целом можно говорить об искусственном дефиците, и следующий случай позволяет понять процедуры создания этого дефрицита.

Также как вся приграничная полоса вдоль китайской границы, остров Русский был перманентно закрытым в советское время. Еще в царское время на нем начали строить Форт Русский (часть фортификационных сооружений Владивостокской крепости). В советское время была возведена батарея, которая способна простреливать практически весь примыкающий залив. Все постройки, имевшиеся на острове в 2011 г., так или иначе были связаны с военными целями. В 2012 г. произошли существенные изменения. На месте бывшей школы мичманов и прапорщиков ТОФ построен лучший в России кампус Дальневосточного университета; в сентябре 2016 г. открыт океанариум мирового класса. В 2018 г. анонсировано строительство культурного центра, сафрари-парка и прочих досуговых учреждений, принципиально меняющих лицо города. Вместо путешествия с материка на остров в течение трех часов на пароме, жители острова добираются по заасоральтированной к саммиту АТЭС дороге по мосту всего за 20 минут.

Можно сказать, что либеральная мечта сбылась: вместо существования в советской военной инфраструктуре люди острова окружены и постоянно соприкасаются с инфраструктурой открытости внешнему миру. На Русском остались бывшие военные поселки, в которых живут семьи бывших или сегодняшних военных, а также и те, кто просто купил квартиры на вторичном рынке. Стоимость жилья в целом ниже, чем в основной части Владивостока. Основная причина состоит в очень плохой транспортной доступности, поскольку дорога, которая была построена "в честь" АТЭС, проложена ровно настолько, насколько это было нужно для обслуживания саммита. Поэтому добравшись до острова за 20 мин на своей машине, человек вынужден добираться до своего дома еще 2 часа по полному бездорожью ${ }^{3}$. Ситуация осложняется тем, что вся территория острова относится к запретной зоне военных объектов Министерства обороны и ничего, включая дороги, не может быть построено без его прямого разрешения. В отличие от многоквартирных домов, оставшихся от военных и сразу пригодных для использования в гражданских целях, прочая военная инфраструктура требовала адаптации, переделки. К тому же, должна была состояться фрормальная передача собственности от военного ведомства к будущим владельцам. Этого до сих пор не произошло, что тормозит гражданское развитие острова. Так, например, строительство дома культуры было анонсировано еще в 2012 г. Однако, по официальной версии, краевой администрации не удалось получить землю запланированного участка в собственность - военные заблокировали строительство этого объекта.

В том же 2012 г. был создан кооператив с целью строительства поселка для специальных категорий граждан (преподавателей, сотрудников научных учреждений и многодетных семей), сроки сдачи домов в котором не раз откладывали. Строительство домов финансируется самими членами кооператива, а инфраструктура строится за счет финансовой помощи государства. Среди многочисленных трудностей, с которым пришлось столкнуться участникам кооператива, - полное несоответствие кадастровой карты реальным материальным объектам, найденным на земельном участке. Карты, по которым составлялось кадастровое описание, были сделаны военными для гражданских целей и поэтому содержали ошибки, неточности. Поэтому кооператоры с удивлением обнаруживали у себя на участке породы реликтовых, запрещенных к вырубке деревьев; археологические памятники; отсутствующие в кадастре, но присутствующие на земле деревянные постройки (самозахваты) под дачи; ручьи и так далее. Для того, чтобы адаптировать все эти "излишества", у кооператоров ушло 3,5 года.

3 На момент публикации статьи ситуация с транспортной доступностью улучшилась - к ВЭФ-2019 заасфральтировали дороги к некоторым поселкам на острове. 
Для передачи государственной, в том числе военной земли, в России создан так называемый "единый институт развития" (АО Дом.pф), в основные функции которого входит передача, коммерциализация земли и содействие развитию жилищного строительства. В случае с кооперативом свою основную фуннкцию данный институт реализовал не только предоставив землю, но и навязав проектные решения (самих домов и организации улиц), а также оказав помощь в выборе генерального подрядчика. Когда у членов кооператива возникли обычные для России сложности с подрядчиком, институт развития в лице его директора обещал "взять стройку под личный контроль" и завершить строительство в обозримые сроки.

\section{Заключение}

Три описанных случая, конечно, не исчерпывают многообразие отношений собственности, но позволяют показать сосуществование - конфлииктное, индифрферентное, симбиотическое - либерально-экономической идеи и реальных захватов. Принципиально важно - никогда не совпадающее.

Выше в тексте мы не уточняли, в чем состоит экономическая идея именно захвата, рассуждая в целом об институте частной собственности. Это не означает, что таких идей не существует и нам для дальнейших рассуждений следует выбрать конкретную модель. Так, Альстон и Миллер [4, 5] предложили модель, описывающую, как захват трансформируется в "идеальную" частную собственность: (а) в условиях изобилия земли, экономические агенты, движимые стимулом к извлечению ренты, производят захваты; затем (б) благодаря объединению колонистов, прибывших ранее, т.е. клубному индорсменту, специфицируется собственность de facto; далее (в) государство, руководствуясь стимулом к извлечению ренты с de facto собственников, предлагает им инфорсмент, который закрепляет собственность de јure.

Очевидно, что из всех трех рассмотренных случаев реальные захваты в "таежном поселке" меньше всего пересекаются с этой моделью. Либерально-экономическая идея собственности попросту "не дошла" до поселка. Депутаты и глава администрации занимаются спецификацией (помогают распределить дома между людьми), предоставляют некоторую защиту имущества, принуждают к выполнению минимальных правил (например, производить оплату по счетам) и выступают арбитрами в конфликтах. Однако они лишь в некоторой степени ориентируются при этом на действующие в России законодательство и в значительной мере - на разделяемые в этом локальном обществе представления о справедливости, социальных нормах, которые сложились в советское время тотального бюрократического контроля.

Если не интересоваться реальными, складывающими при выполнении Программы ДВ-гектар отношениями собственности, то ее дизайн в целом соответствует модели Альстона-Миллера: экономические агенты, заинтересованные извлечением земельной ренты, должны получить стимул к захвату свободной земли (гектара). Впоследствии, убедившись в том, что de facto собственники эффрективно управляют своим ресурсом, государство формализует им право de jure, и, вероятно, начнет извлекать земельную ренту (налог). На практике все работает иначе: "захватчиков" интересуют не "свободные" земли, а те, которые уже обрабатываются, более того, на которые государство уже оформляло права собственности, то есть гарантировало предоставление инфорсмента. При этом близость "захватчика" к представителю государства дискурсивно объясняет, почему инфорсмент не работает. То есть в представлении экономических агентов оформление права de јure ему, агенту, совершенно не нужно, поскольку он не надеется, что его права будут в результате лучше защищены; оформление права работает только как стимул государства к извлечению ренты с de jure собственников. Кстати, сейчас уже стало понятно, что программа "ДВ-гектар" в задуманном разработчиками варианте не работает, что подтверждают постоянные поправки и уточнения в предлагаемых механизмах получения участков. И основная причина именно в бесконечном множестве "кадастровых ошибок", подобных описанным в нашем случае. То есть при существовании de facto собственников их переведение в статус de jure сильно затруднено. Таким образом, захваты, подобные описанным в нашем случае, сильно модифицируют и тормозят реализацию либерально-экономической идеи Программы. 
Изучая институты, современные экономисты акцентируют внимание на стимулах (почему люди ведут себя определенным образом) и основаниях этих стимулов (почему стимулы такие). Исходя из модели, например, основание в виде изобилия земли стимулирует экономических агентов к извлечению ренты через захват. Если обратиться к случаю "Таежный поселок", становится очевидным, что едва ли стимулы захвата хоть как-то связаны с желанием извлечь ренту. Сами люди, с которыми общался один из авторов статьи, говорили, о чем угодно, кроме желания получения дохода - о социальной справедливости, о ненужности объектов недвижимости и в целом поселка государству, о лучшей сохранности домов благодаря тому, что в них "кто-то поживет". Можно возразить, что в модели Альстона-Миллера основным фрактором является стоимость земли, которая приближается к нулю в случае таежного поселка. И в этом смысле дефицит, который искусственно создается из-за "аппетита" военного ведомства (как описано в случае "Остров") - нужный механизм искусственного повышения стоимости, который формирует "правильные" либеральные стимулы и в дальнейшем приведет к созданию частной собственности. Тогда мы должны признать, что захваты земли через многочисленные коррупционные схемы - это тоже правильный механизм, ведь только благодаря ему и создается рынок земельных участков. Но как же тогда быть с инфорсментом, который должен предлагаться государством и быть единым для всех экономических агентов? Совершенно очевидно, что ни о каком едином инфорсменте прав собственности речь не идет и идти не может.

Возвращаясь к вопросу о бесконечном множестве вариантов сосуществования идеи о частной собственности и "реальных" захватов, подчеркнем, что удивительным образом в некоторой степени правы и Каллон (так как либеральная идея, конечно, сильно изменила реальные отношения собственности), и Миллер (так как реальный рынок сопротивляется тому, что предписывает идея).

\section{Литература}

1. Рыжова Н. П., Гузей Я. С., Карбаинов Н. И. Институт собственности на землю: захваты, "ресурсное изобилие" и особенности инфорсмента на российском Дальнем Востоке // Ойкумена. Регионоведческие исследования. 2017. № 4. C. 40-54. DOI: 10.24866/1998-6785/2017-4/40-54.

2. Фуруботн Э. Г., Рихтер Р. Институты и экономическая теория. Достижения новой институциональной экономической теории. Пер. с англ. под ред. В. С. Катькало и Н. П. Дроздовой. СПб: Издательство СПбГУ, 2005. 702 с.

3. Allina-Pisano, J. The post-Soviet Potemkin village: politics and property rights in the black earth. Cambridge, UK.: Cambridge University Press, 2008. 248 p.

4. Alston L. J., Harris E., Mueller B. De Facto and de Jure Property Rights: Land Settlement and Land Conflict on the Australian, Brazilian and U.S. Frontiers // NBER Working Papers № 15264 / National Bureau of Economic Research, Inc., 2009. [Электронный peсуpc]. URL: https://ideas.repec.org/p/nbr/nberwo/15264.html (дата обращения 19.10.2019).

5. Alston L. J., Mueller B. Property Rights, Land Conflict and Tenancy in Brazil // NBER Working Paper № 15771 / National Bureau of Economic Research, Inc., 2010. [Электронный ресурc]. URL: http://www.nber.org/papers/w15771.pdf (дата обращения 10.11.2019)

6. Cahill K. Who owns Britain? The hidden facts behind landownership in the UK and Ireland. Edinburgh: Canongate Books, 2002.450 p.

7. Callon M., Muniesa F. Economic Markets as Calculative Collective Devices // Organization Studies. 2005. № 26(8). Pp.1229-1250. DOI: 10.1177/0170840605056393

8. De Soto H. The Other Path: The invisible revolution in the third world. NY: Basic Book, 1989. 271 p.

9. Elyachar J. Markets of Dispossession: NGOs, Economic Development, and the State in Cairo. Durham: Duke University Press, 2005. 296 p.

10. Hann C. Reproduction and Inheritance. Goody Revisited // Annual Review of Anthropology. 2008. № 37. Pp. 145-158.

11. Honore A. M. Ownership // Oxford essays in jurisprudence. Ed. by A.G. Guest. Oxford, 1961. Рp. 112-128. [Цит. по Капелюшников Р. И. Экономическая теория прав собственности (методология, основные понятия, круг проблем) М.: ИЭ АН СССР.1990. 90 c.]. 
12. Macfarlane A. The mystery of property: inheritance and industrialization in England and Japan // Property Relations. Ed. by C.M. Hann. University of Kent at Canterbury, 1998. Pp. 104-123.

13. Miller D. Turning Callon the Right Way Up // Economy and Society. 2002. № 31 Pp. 218-233. DOI.10.1080/03085140220123135

14. Singer J.W. Entitlement: The Paradoxes of Property. New Haven: Yale University Press, 2000. $256 \mathrm{p}$.

15. Verdery K. The Property Regime of Socialism // Conservation \& Society. 2004. № 2. Pp. 189-198.

16. Verdery K. Fuzzy Property: rights, power and identity in Transylvania's Decollectivization // Uncertain Transition: ethnographies of change in the post-socialist world. Ed. by M. Burawoy and K. Verdery. Oxford: Rowman and Littlefield, 1999. Pp. 102117.

\section{Транслитерация по ГОСТ 7.79-2000 Система Б}

1. Ryzhova N. P., Guzej YA. S., Karbainov N. I. Institut sobstvennosti na zemlyu: zakhvaty, "resursnoe izobilie" i osobennosti inforsmenta na rossijskom Dal'nem Vostoke // Ojkumena. Regionovedcheskie issledovaniya. 2017. № 4. C. 40-54. DOI: 10.24866/19986785/2017-4/40-54.

2. Furubotn Eh. G., Rikhter R. Instituty i ehkonomicheskaya teoriya. Dostizheniya novoj institutsional'noj ehkonomicheskoj teorii. Per. s angl. pod red. V. S. Kat'kalo i N. P. Drozdovoj. SPb: Izdatel'stvo SPbGU, 2005. $702 \mathrm{~s}$.

3. Allina-Pisano, J. The post-Soviet Potemkin village: politics and property rights in the black earth. Cambridge, UK.: Cambridge University Press, 2008. 248 p.

4. Alston L. J., Harris E., Mueller B. De Facto and de Jure Property Rights: Land Settlement and Land Conflict on the Australian, Brazilian and U.S. Frontiers // NBER Working Papers № 15264 / National Bureau of Economic Research, Inc., 2009. [Ehlektronnyj resurs]. URL: https://ideas.repec.org/p/nbr/nberwo/15264.html (data obrashheniya 19.10.2019).

5. Alston L. J., Mueller B. Property Rights, Land Conflict and Tenancy in Brazil // NBER Working Paper № 15771 / National Bureau of Economic Research, Inc., 2010. [Ehlektronnyj resurs]. URL: http://www.nber.org/papers/w15771.pdf (data obrashheniya 10.11.2019).

6. Cahill K. Who owns Britain? The hidden facts behind landownership in the UK and Ireland. Edinburgh: Canongate Books, 2002.450 p.

7. Callon M., Muniesa F. Economic Markets as Calculative Collective Devices // Organization Studies. 2005. № 26(8). Pp.1229-1250. DOI: 10.1177/0170840605056393

8. De Soto H. The Other Path: The invisible revolution in the third world. NY: Basic Book, 1989. $271 \mathrm{p}$.

9. Elyachar J. Markets of Dispossession: NGOs, Economic Development, and the State in Cairo. Durham: Duke University Press, 2005. 296 p.

10. Hann C. Reproduction and Inheritance. Goody Revisited // Annual Review of Anthropology. 2008. № 37. Pp. 145-158.

11. Honore A. M. Ownership // Oxford essays in jurisprudence. Ed. by A.G. Guest. Oxford, 1961. Pp. 112-128. [TSit. po Kapelyushnikov R. I. Ehkonomicheskaya teoriya prav sobstvennosti (metodologiya, osnovnye ponyatiya, krug problem) M.: IEH AN SSSR.1990. $90 \mathrm{s.}]$.

12. Macfarlane A. The mystery of property: inheritance and industrialization in England and Japan // Property Relations. Ed. by C.M. Hann. University of Kent at Canterbury, 1998. Pp. 104-123.

13. Miller D. Turning Callon the Right Way Up // Economy and Society. 2002. № 31 Pp. 218-233. DOI.10.1080/03085140220123135

14. Singer J.W. Entitlement: The Paradoxes of Property. New Haven: Yale University Press, 2000.256 p.

15. Verdery K. The Property Regime of Socialism // Conservation \& Society. 2004. № 2. Pp. $189-198$.

16. Verdery K. Fuzzy Property: rights, power and identity in Transylvania's Decollectivization // Uncertain Transition: ethnographies of change in the post-socialist world. Ed. by M. Burawoy and K. Verdery. Oxford: Rowman and Littlefield, 1999. Pp. 102-117. 
Рыжова Н. П., Журавская Т. Н. Идея о частной собственности и "реальные" захваты земли.

Статья посвящена обсуждению вопроса о связи земельных захватов и института частной собственности, основанной на выводе о формировании культурно специфичного по сравнению с американской или австралийской моделью института на Дальнем Востоке. Авторы рассматривают не связь реальных захватов и сложившихся отношений собственности, а сосуществование идеи о ней и «реальных» захватов в перформативной традиции М. Каллона. Результаты проведенного исследования позволяют не просто утверждать, что все отношения собственности, формируемые благодаря захватам, несравнимы с идеальными моделями, «списанными» с англосаксонского права, но и показать значение конкретного контекста для формируемой модели взаимоотношений. Так, показано, что либерально-экономическая идея могла способствовать переводу захваченных ранее земель в частные владения и приближению этих отношений к идеальной экономической модели; могла вообще остаться «незамеченной» в реальности; реальные захваты могли откорректировать способы воплощения либерально-экономической идеи о собственности в реальности и многообразие других вариантов. Исследование основано на эмпирических исследованиях на Дальнем Востоке в формате кейс-стади.

Ключевые слова: захваты, институт собственности на землю, фронтир, стимуль и основания, либеральная повестка, российский Дальний Восток

Ryzhova N. P., Zhuravskaya T. N. The idea of private property and "real" captures of land.

The article is devoted to the discussion of the connection between land captures and the private property that is based on the conclusion that in comparison with the American or Australian model a culturally specific private property institute has been formed in the Far East. The authors do not consider the connection between real captures and established property relations, but the coexistence of the idea of it and the "real" captures in the performative tradition of M. Callon. The results of the study made it possible not only to assert that all property relations formed by land captures are not comparable with ideal models "written off" from Anglo-Saxon law, but also show the significance of the specific context for the relationship model being formed. Thus, it was shown that the liberal-economic idea could help transfer the previously captured lands to private ownership and brings these relations closer to the ideal economic model; could in general remain "unnoticed" in reality; real captures could adjust the ways in which the liberal economic idea of ownership in reality could be implemented; and a variety of other options. The study is based on empirical studies in the Far East in the case study format.

Key words: captures of land, private property institute, frontier, incentives and basis, liberal agenda, Russian Far East

Для цитирования: Рыжова Н. П., Журавская Т. Н. Идея о частной собственности и "реальные" захваты земли // Ойкумена. Регионоведческие исследования. 2020. № 1. С. 31-40. DOI: $10.24866 / 1998-6785 / 2020-1 / 31-40$

For citation: Ryzhova N. P., Zhuravskaya T. N. The idea of private property and "real" captures of land // Ojkumena. Regional researches. 2020. № 1. P. 31-40. DOI: 10.24866/1998$6785 / 2020-1 / 31-40$ 


\section{Об особенностях загрязнения атмосферного воздуха на территории Дальнего Востока России}

В географическом отношении к Дальнему Востоку России (ДВ) относят те субъекты, которые входят в "притихоокеанскую часть России" [10]. Рассматриваемый регион, который протянулся с юга на север на 4,5 тыс. км и занимает площадь 3,118 млн кв. км, делят на две части: 1) южную, куда входят Приморский и Хабаровский края, Амурская область, Еврейская автономная область, Сахалинская область, включающая Курильские острова; 2) северную, включающую Камчатский край, Магаданскую область и Чукотский автономный округ.

Актуальность темы не вызывает сомнения, так как әкономические реформы последних трёх десятилетий очень неоднозначно сказались на общей экологической обстановке региона, особенно загрязнении атмосферы - главном негативном фракторе, ухудшающем здоровье людей.

Цель статьи - изучение особенностей состояния атмосферного воздуха ДВ в территориальном отношении с приоритетом в исследовании городских агломераций, концентрирующих наибольшую часть источников загрязнения.

Объектом исследования является ДВ, однако основной акцент при его характеристике сделан на тех территориях, которые являются самыми освоенными в хозяйственном отношении (Приморский, Хабаровский края и Сахалинская область), а в них на городах с широким экономическим развитием и большим населением (Хабаровск и Владивосток).

В изучении данной темы применялись следующие методы: статистический, сравнительно-географический, картографический и другие.

Фактический материал, который использовал автор, - это в основном доклады о состоянии окружающей среды за последние годы по каждому из субъектов ДВ, которые публикуются Минприроды РФ, а также публикации автора и его коллег. Следует заметить, что автор с 80-х гг. XX в. интересуется экологическим состоянием региона, вследствие чего постарался использовать сравнительный метод в широком временном диапазоне. При этом использовались такие общепринятые в Гидрометеослужбе понятия, как Индекс загрязнения атмосферы (ИЗА), рассчитываемый по 5 основным поллютантам и дающий общую картину загрязнения атмосферы; стандартный индекс (СИ), то есть максимальная годовая концентрация любого поллютанта, делённая на ПДК (предельно допустимую концентрацию).

При характеристике данной темы следует хотя бы кратко осветить те общие физико-географические условия региона, которые во многом определяют особенности его атмосферного загрязнения [14]: 1) его расположение в контактной зоне между самыми крупными геоструктурами Земли - континентом Евразия и Тихим океаном, что диктует повышенную ветровую нагрузку на побережье; 2) сложность климата, которая заключается в наличии на его площади трёх климатических поясов (умеренного на юге и в центральной части до Пенжинской губы Охотского моря, субарктического на большей части Чукотского автономного округа и Магаданской области, а также арктического на чукотском побережье Северного Ледовитого океана), каждый из которых дифференцируется на климатические области с преобладанием муссонной циркуляции, переходящей в островных и полуостровных зонах в морскую; 3) широкое разнообразие рельедра, заключающееся в сложном чередовании равнинных участков с горными системами (от низкогорных до высокогорных),

\footnotetext{
(C) Наумов Ю. А., 2020
}

НАУМОВ Юрий Анатольевич, д-р геогр. наук, профессор Находкинского филиала Владивостокского государственного университета экономики и сервиса (2. Находка). E-mail: naumov_ua@, mail.ru 
Таблица 1. Выбросы загрязняющих веществ в атмосфреру в субъектах Дальнего Востока от автотранспорта (A) и стационарных источников (С И)

\begin{tabular}{|c|l|c|c|c|}
\hline \multirow{2}{*}{ № } & \multirow{2}{*}{ Название субъектов } & \multicolumn{3}{|c|}{ Объем выброса } \\
\cline { 3 - 5 } & & $\mathbf{A}$ & $\mathbf{C ~}$ & сумма \\
\hline 1 & Приморский край (2018 г.) & 244,1 & 186,14 & 430,54 \\
\hline 2 & Хабаровский край (2018 г.) & 138,2 & 117,9 & 256,1 \\
\hline 3 & Амурская область (2017 г.) & 82,8 & 112,6 & 195,4 \\
\hline 4 & Сахалинская область (2017 г.) & 105,0 & 61,6 & 166,6 \\
\hline 5 & Камчатский край (2017 г.) & 52,7 & 76,3 & 129,0 \\
\hline 6 & Магаданская область (2014 г.) & 28,5 & 25,4 & 53,9 \\
\hline 7 & Еврейская автономная область (2018 г.) & 16,1 & 18,6 & 34,7 \\
\hline 8 & Чукотский автономный округ (2018 г.) & 4,9 & 21,6 & 26,5 \\
\hline
\end{tabular}

Источник: составлено автором.

извилистой береговой линии, определяющей большое разнообразие микроклиматических условий.

В описании субъектов ДВ мы придерживались последовательности изложения материала с юга на север.

Приморский край [5]. Он входит в число наиболее развитых в экономическом отношении субъектов ДВ, занимая 1-е место по численности населения (1,9 млн человек на 2019 г.), а также количеству городов - 12, уровню автомобилизации (983,5 тыс. автомобилей), развитию транспортной инфраструктуры, грузообороту и мощности топливно-энергетического комплекса (ТЭК). В связи с этим край занимает 1-е место по выбросам, что отражено в табл. 1. Всё это с учетом влияния горно-добывающей промышленности и переработки полезных ископаемых создаёт повышенную антропогенную нагрузку на окружающую среду, особенно городскую, однако мониторинг атмосферного воздуха Гидрометеослужба проводит только в 5 городах.

В этой характеристике края нельзя обойти стороной и глобальные атмосферные процессы, когда трансграничные воздушные потоки оказывают дополнительное загрязняющее воздействие на его территорию. Например, взрыв на Чернобыльской АЭС в 1986 г. и испытания ядерного оружия КНР в пустыне Гоби в 70-80-х годах привели к тому, что Гидрометеослужба зафиксировала во Владивостоке повышение концентрации трития в воздухе в 7 раз: с 44 TE (тритиевых единиц) до 310 ТЕ. При этом среднегодовая концентрация радиоактивных аэрозолей в 80-е годы повысилась в 3,8 раза [15].

К настоящему времени всё большее негативное воздействие на южную половину края оказывают промышленные выбросы бурно развивающейся экономики КНР. Метеостанции Владивостока с 90-х годов отмечают такое явление, как кислотные дожди, когда особенно в последние годы концентрации сульфатов и нитратов выросли, соответственно, в 1,1 и 2 раза. Кислотно-щелочной показатель за последние 20 лет изменился от 5,6 единиц РН до 4 единиц и ниже. Растет и запыленность атмосферы ДВ, особенно в весенние месяцы, когда в пустыне Гоби буйствуют пыльные бури. Так, с начала XXI в. во Владивостоке в такие периоды концентрация пыли была в 174 раза выше среднесуточной спокойного зимнего периода.

Лесные пожары в крае, по сравнению с другими регионами ДВ, имеют свою специфику воздействия: они распространены весной и осенью, а в малоснежные годы даже зимой.

Наиболее полно загрязнённость воздуха изучается в краевом центре - Владивостоке. Этот город имеет наибольшее население 605 тыс. человек на 1 января 2018 г.), самую высокую концентрацию автотранспорта, развитую промышленность (ТЭК, машиностроение, особенно судостроение и судоремонт, химическое производство и строительство). 
Обобщение данных Гидрометеослужбы по Владивостоку за 80-е годы показало, что по основным поллютантам уже тогда загрязнение достигало высоких значений: по взвешенным веществам (BB) до 22,7 ПДК в центре города; по двуокиси серы - 7,2 ПДК; по двуокиси азота - 34,5 ПДК; по оксиду углерода - 13 ПДК; по соединениям свинца - 2,6 ПДК.

Уже в начале 80-х гг. XX в. города Владивосток и Артем по существу слились в единую агломерацию, а граница между ними стала условной. Это явление нашло четкое отражение в том, что ореол повышенного загрязнения охватывает не только всю агломерацию, но и юг Приморья [9].

Обобщенные сведения о состоянии загрязнения воздуха в городах Приморского края за 2017 г. свидетельствуют, что высокий уровень загрязнения воздуха отмечался в г. Уссурийске (ИЗА=11; СИ=12,2 по бензапирену) и повышенный уровень загрязнения в г. Владивостоке (ИЗА=5; СИ=3,6 по бензапирену). В городах Артём и Дальнегорск уровень загрязнения оценен как "низкий", а в г. Находке как "ориентировочно низкий".

Более всего воздух в городах загрязнён диоксидом азота, а также бензапиреном в гг. Уссурийске и Владивостоке.

Среднегодовые концентрации бензапирена в 2017 г. превышали допустимую норму в Уссурийске - в 3,3 раза и во Владивостоке - в 1,1 раза.

По сравнению с прошлым годом среднегодовые концентрации бензапирена увеличились в 2017 г. в городе Уссурийске - в 1,2 раза. В городе Владивостоке его среднегодовые концентрации в 2017 г. уменьшились в 1,1 раза по сравнению с предыдущим годом.

Среднегодовые концентрации диоксида азота превысили допустимую норму в г. Уссурийске - в 2,7 раза, в г. Артёме - в 1,4 раза, а в городах Дальнегорске, Находке и Владивостоке - в 1,1 раза. Максимальная концентрация диоксида азота - 2,4 ПДК., зарегистрирована в городе Артёме.

Среднегодовая концентрация (ВВ), то есть пыли превысила допустимую санитарную норму (ПДК) только в городе Уссурийске в 1,1 раза.

Наблюдения за содержанием формальдегида проводились только в г. Владивостоке. Его основным источником является автотранспорт. Средняя за год концентрация этого поллютанта составила 1,4 ПДК.

Среднегодовые концентрации оксида углерода в городах Приморья не превысили допустимую санитарную норму (ПДК). Максимальная концентрация оксида углерода 2,0 ПДК была зарегистрирована в г. Владивостоке.

Среднегодовые концентрации загрязняющих веществ превышали ПДКср.сут. в следующих городах: Владивостоке (формальдегид, бензапирен, диоксид азота,), Артёме (диоксид азота), Уссурийске (диоксид азота, бензапирен, взвешенные вещества), Находке (диоксид азота), Дальнегорске (диоксид азота).

Неблагополучное экологическое состояние воздушного бассейна во Владивостоке и в Уссурийске обусловлено, в основном, огромным количеством автотранспорта. Проезжая часть улиц городов значительно уменьшается за счет парковки автомобилей с обеих сторон, что затрудняет движение, создаёт "пробки" и способствует увеличению загазованности воздуха. Свой вклад вносят и выбросы технически устаревших производственных объектов. Загрязнению воздушного бассейна в городах края способствует использование низкокачественного топлива на предприятиях электроэнергетики и сотнях малых котельных края, высокая повторяемость приземных, приподнятых инверсий и слабый ветер.

Наибольший процент неудовлетворительных проб атмосфрерного воздуха по ВВ отмечается на территории г. Находки и составляет $8,5 \%$, что связано с перевалкой угля открытым способом.

В 2017 г. регистрировалось превышение ПДК загрязняющих химических веществ в атмосферном воздухе на территории сельских поселений $(2017-6 \%, 2016-7,1 \%)$.

Вся эта самая современная цифровая информация безусловно важна, но её необходимо дополнить сведениями различных специалистов о специфике загрязнения городов Приморья, которая была установлена за последние десятилетия. Так, в г. Большом Камне отмечались выбросы в атмосферу радионуклидов оборонным предприятием "Звезда" с превышением природного фона до 10 раз [15]. 
В пос. Рудная Пристань, который в докладах 80-х и 90-х гг. был отнесен к населенным пунктам с очень высоким уровнем загрязнения воздуха из-за выбросов завода по выплавке свинца, даже после его закрытия в почвах сохранились концентрации свинца, ртути, кадмия и цинка, превышающие ПДК в десятки, сотни и тысячи раз. Сам район вокруг завода был отнесён в докладах к "зоне экологического неблагополучия" [17].

Уссурийск часто в докладах попадает в число самых загрязненных городов РФ. Это связанно с тем, что, с одной стороны, его многочисленные котельные крайне устарели, многие из них не имеют пыле- и газоочистки, с другой стороны - через город проходит федеральная магистраль, выхлопные газы от автомобильного потока усиливают загрязнение воздуха. В связи с этим именно этот город среди других выделяется "рекордными" концентрациями по бензапирену (до 12,1 ПДК).

Спасск выделяется работой двух цементных заводов, пыль от которых оказывает специфическое воздействие на здоровье населения этого города. Если в Уссурийске (ВВ) представляют собой преимущественно золу и сажу, то в Спасске - это частицы цементной пыли. Оба типа частиц имеют существенные морфологические отличия и специфическое биологическое действие на организм. Частицы сажи имеют сферическую или уплощенную форму, а частицы цементной пыли удлиненную и веретенообразную, что способствует их более легкому и глубокому проникновению во внутреннюю среду организма, вызывающему необратимые процессы в системах организма и клетках. Вот почему, несмотря на то, что Спасск уступает Уссурийску по валовому выбросу загрязняющих веществ, его цементная пыль по сравнению с сажей оказывает более неблагоприятное воздействие на организм людей, что подтверждает статистика более высокой заболеваемости населения этого города.

Партизанск характеризуется наличием целого ряда закрытых шахт, часть которых в нарушении "Закона о недрах" была затоплена. При этом вода, проникая в подземные выработки, вытесняла рудничные газы (метан, радон, углекислый газ, сероводород) на поверхность, нередко с превышающими санитарные нормы концентрациями.

Находка является самым крупным транспортным комплексом на ДВ: её порты посещают ежегодно более 9000 судов. Подавляющая часть грузов приходится на уголь, что определило значительное загрязнение городской атмосферы угольной пылью. В 2016 г., по данным санитарной службы, ПДК по пыли превышалась в 5 раз. О том, насколько плотно концентрируются источники опасности, наиболее наглядно можно увидеть на примере бухты Находка, где мы выделяем три транспортные ветки города, которые ориентированы в форме подков параллельно друг другу вдоль береговой линии: 1-я ветка - это цепочка из дымящих морских судов у причалов; чуть бережнее (в 20-40 м) 2-я ветка ж/д линий, где на 4-6 путях могут скапливаться составы с топливом, от которых распространяется резкий запах нефтеуглеводородов; 3-я ветка - автомагистраль Находкинского проспекта с интенсивным движением автотранспорта и постоянным шлейфом выхлопных газов. От первой "подковы" до ближайших домов 80-150 м, а от автомагистрали и того меньше - 10-15 м. Но ситуация усугубляется ещё и тем, что внутри әтих техногенных "подков" располагается ряд котельных и угольных терминалов. Как следствие, над бухтой часто отмечается смог, чему благоприятствует также амфитеатральное низкогорное окружение её акватории. При рассмотрении данной проблемы не учитывается ещё и субъективность оценки загрязнения воздуха, которую можно показать на следующем фракте. Параллельно Находкинскому проспекту, всего в 40-70 м от жилых домов, протягивается ж/д магистраль с интенсивным движением грузовых составов, подавляющая часть которых следует в нефтеналивной порт, а значит, включает цистерны с нефртепродуктами (НП). В тёплый день, находясь рядом с ними, на автобусной остановке, чувствуешь исходящий от них резкий запах летучих НП, который тогда широко распространяется на прилегающие дома, когда на всех шести ветках скапливается целый ряд составов, насчитывающих сотни цистерн. По заявлению санитарных врачей, это запах полициклических ароматических углеводородов (ПАУ), являющихся канцерогенами, то есть веществами, вызывающими онкологические заболевания. Однако замеры концентраций ПАУ никогда не проводились. 
В связи с этим неудивительно, что, по данным заведующего онкодиспансером Находки И. Заярного, "Количество онкозаболеваний в Находке и Приморском крае растёт. В Находке с 2007 г. по 2012 г. в среднем заболевали 600 человек в год, только в 2013 г. выявлено 636 человек".

Проблема с неустановленными концентрациями ПАУ носит вовсе не локальный характер, потому как упомянутый специфический запах исходит также и от морской акватории, на которой нередки аварийные разливы НП. Немногочисленные специалисты Росприроднадзора не успевают реагировать на эти разливы [12].

Артем имеет свою специфику загрязнения. Исследования специалистов [13] показали, что в атмосферу этого города ежегодно выбрасывается 7,5 т. ртути. Это результат сжигания бурых углей. Если учесть, что на этих углях работает ряд ТЭЦ и котельных других городов края, то можно предполагать наличие и в их атмосфере этого высокотоксичного металла, не входящего в перечень компонентов анализируемых Приморгидрометом.

Очень интересное исследование было проведено по интегральной оценке экологического риска распространения заболеваемости органов дыхания в городах края под руководством известного специалиста, доктора медицинских наук П. Ф. Кику [11]: установлено, что в этом отношении наибольший риск проявляется во Владивостоке. Он связан с тем, что загрязнение воздуха от автомобилей действует на организм человека в 4-5 раз сильнее, чем от загрязнения промышленными предприятиями. Причина в комбинационном воздействии на организм нескольких сот токсичных поллютантов, содержащихся в выхлопных газах. Исходя из этого, города Приморья в порядке уменьшения загрязнения их воздуха выстраиваются в такой последовательности: Владивосток, Уссурийск, Артем, Дальнегорск, Партизанск, Находка, Большой Камень, Арсеньев, Дальнереченск.

Таким образом, в целом Приморский край стоит на 1-м месте по уровню загрязнения основными поллютантами среди других регионов ДВ. Проблема оздоровления атмосферы Приморского края назрела давно, так как из года в год в докладах подчеркивалась изношенность объектов ТЭК, нуждающихся в модернизации. Наиболее заметно модернизация стала проводиться в последние годы. Так, "Владивостокская ТЭЦ-2" была переведена с угля на газ, что заметно снизило пылевую нагрузку одного из микрорайонов Владивостока. C 2015 г. в городах и поселках края были построены 139 новых модульных автоматизированных котельных. Они имеют котлы с дистанционным контролем, автоматизированными системами топливоподачи и золошлакоудаления. Котельные переводят с дорогих видов топлива (дизельного и мазута) на более дешевый уголь, совершенствуя очистку отходящих газов и пыли [16].

Однако, несмотря на эти положительные шаги, остается нерешенным вопрос внедрения альтернативных источников получения энергии: если в других регионов РФ (Алтай, Оренбургская область, Башкортостан) строятся солнечные электростанции и ветроэнергетические установки, то в Приморье построение ветропарка на островах Русский и Попова в 2012 г. было сорвано.

Что касается мобильных источников загрязнения, то в отношении их еще слабо ведется работа по переводу автотранспорта на газомоторное топливо ввиду острой нехватки газозаправочных стаций. Пока только в 2018-2019 гг. во Владивостоке, Уссурийске и Находке появилось 10 быстрозарядных установок для обслуживания электромобилей. По числу последних Приморье является лидером среди других субъектов ДВ.

Хабаровский край [7]. Численность его населения составляет 1,3 млн человек (2018 г.). Край выделяется развитым машиностроением, горно-добывающей промышленностью и металлургией. Его территория подвержена меньшему трансграничному загрязнению воздушными потоками со стороны Китая, но лесные пожары в теплое время года оказывают самое сильное негативное воздействие на население и биоту из всех регионов ДВ. В некоторые годы от пожаров страдает до 2 млн га леса, и тогда Хабаровск заволакивает дым. Как следствие, в нем повышается уровень заболевания горожан. Город Хабаровск является центром машиностроения ДВ и самым крупным в регионе по населению (618 тыс. человек на 1 января 2019 г.). Основной вклад в выбросы от стационарных источников вносят ТЭК (Хабаровская ТЭЦ-1, 
ТЭЦ-3, многочисленные котельные, Хабаровский нефтеперерабатывающий завод - НПЗ). Вклад автотранспорта в суммарный выброс составляет $45 \%$.

Из основных примесей атмосфера города в 2017 г. более всего была загрязнена ВВ (среднегодовое содержание - 1,0 ПДК, максимальное из разовых - 2,2 ПДК) и диоксидом азота (среднегодовое содержание на уровне 1,0 ПДК, максимальное из разовых - 1,2 ПДК).

Среднегодовое содержание оксида углерода не превышает 1,0 ПДК, максимальное разовое содержание составляет 1,6 ПДК.

Максимальная из разовых концентраций сероводорода превышает норму в 2,5 раза. Средняя за год величина формальдегида превышает норму в 1,2 раза, максимальная - в 2,1 раза.

Среднегодовые и максимальные разовые концентрации ПАУ (полициклических ароматических углеводородов) находятся в пределах санитарной нормы. Исключение составляет этилбензол, максимальное значение которого превышает ПДК в 4 раза.

По отношению к 2016 г. отмечается снижение средней за год концентрации бензапирена до 1,5 ПДК (2016 г. - 2,0 ПДК). Максимальное из среднемесячных значений в феврале достигало уровня 5,5 ПДК (2016 г. - 7,7 ПДК).

Уровень загрязнения воздуха повышенный, обусловленный заметным содержанием бензапирена и формальдегида.

Снижение степени загрязнения воздуха обусловлено изменением гигиенического норматива по формальдегиду (2014 г.) и френолу (2015 г.), что в свою очередь не имеет отношения к реальному уровню загрязнения атмосфрерного воздуха.

Тенденция за период 2013-2017 гг.: увеличение концентраций сажи и формальдегида. Относительно 2013 года это повышение концентрации диоксида азота, углерода (сажи), аммиака, бензола и этилбензола.

В тенденции за период 2008-2017 гг. выраженного роста концентраций наблюдаемых примесей не обнаружено. Относительно 2008 г. повысились концентрации аммиака и формальдегида.

В г. Комсомольск-на-Амуре основной вклад в выбросы от стационарных источников вносят объекты ТЭК (Комсомольская ТЭЦ-2, Комсомольский НПЗ, сталелитейный завод "Амурметалл", судостроительный и авиационный заводы). Вклад автотранспорта в суммарный выброс составляет $44 \%$.

Из основных загрязняющих примесей следует отметить ВВ. Их среднегодовое содержание находится на уровне 2016 г. (1,5 ПДК). Загрязнение бензапиреном по сравнению с 2016 г. немного снижается: среднегодовая концентрация составляла 2,1 ПДК (в 2016 г. - 2,2 ПДК), максимальное из среднемесячных значений - 6,3 ПДК (в 2016 г. - 7,4 ПДК).

Уровень загрязнения воздуха высокий и обусловлен повышенным средним содержанием бензапирена и ВВ. Наиболее загрязнен воздух в районах, расположенных вблизи перекрестков дорог с интенсивным движением автомобильного транспорта и в зоне влияния выбросов промышленных предприятий.

В тенденции за период 2013-2017 гг. отмечается рост концентраций аммиака и френола, а относительно 2013 г. возросли концентрации оксида углерода, сероводорода и формальдегида.

В тенденции за период 2008-2017 гг. выраженного роста наблюдаемых примесей не отмечается, но относительно 2008 г. повысились концентрации сероводорода и френола.

В пос. Чегдомын основными источниками загрязнения атмосферы являются котельные и предприятие ОАО "Ургалуголь".

Вклад автотранспорта в суммарный выброс составляет 16 \%. В ноябре 2017 года в пос. Чегдомын выявлен 1 случай высокого загрязнения (В3) по формальдегиду (23,3 ПДК). Среднегодовая концентрация данной примеси находится на уровне 2,5 ПДК. Средняя за год концентрация ВВ составляет 1,3 ПДК, максимальная из разовых достигает уровня 1,8 ПДК. Среднегодовая величина бензапирена, по сравнению с прошлым годом, снизилась и составляла 4,2 ПДК (в 2016 - 5,8 ПДК). Максимальное значение из среднемесячных обнаружено в феврале и находится на уровне 9,9 ПДК.

Уровень загрязнения воздуха очень высокий и обусловлен повышенным средним содержанием формальдегида и бензапирена. 
В г. Николаевске-на-Амуре основные источники загрязнения атмосферы - Николаевская ТЭЦ, судостроительный и судоремонтный заводы, котельные и автотранспорт.

Вклад автотранспорта в суммарный выброс составляет 42 \%. Максимальное из разовых содержание ВВ превышает норму в 1,6 раза, диоксида азота - в 1,1 раза. Среднегодовая концентрация не превышает норму, максимальное из среднемесячных значений - 2,8 ПДК (в 2016 г. - 5,3 ПДК). Несмотря на то, что по комбинированному загрязнению на 1-м месте находится Хабаровск, пос. Чегдомын явно выделяется высокими показателями по формальдегиду (до 23,3 ПДК) и бензапирену (до 9,9 ПДК).

Общий анализ состояния загрязнения Хабаровского края показывает, что он может быть отнесен к числу регионов с повышенной антропогенной нагрузкой на атмосферу, так как по формальдегиду ПДК превышается в 23,3 раза, а по бензапирену в 9,9 раза.

Амурская область [1]. Численность населения области составляет 800 тыс. человек. Ее трансграничное воздействие загрязнения со стороны Китая уступает по своей силе только Приморью, а лесные пожары каждый год охватывают площадь в десятки и даже тысячи гектаров. В г. Благовещенске основные источники загрязнения атмосферы: Благовещенская ТЭЦ, котельные, а также автотранспорт. Концентрации диоксида азота: среднегодовая по сравнению с 2014 г. повысилась до уровня 2 ПДК (в 2013 г. - 1,4 ПДК). Загрязнение бензапиреном по сравнению с прошлым годом повысилось. Его среднегодовое содержание составляет 5,5 ПДК (в 2013 г. - 3,7 ПДК). В январе и декабре обнаружены высокие уровни загрязнения, максимальное из среднемесячных значений в декабре достигало уровня 20,2 ПДК. Степень загрязнения воздуха в области очень высокая и определяется среднегодовым содержанием бензапирена.

Тенденция за период 2010-2014 гг. такова: концентрации ВВ, диоксида серы, диоксида азота, бензапирена возросли.

Тенденция за период 2005-2014 гг. также вызывает тревогу: среднегодовые концентрации диоксида азота, бензапирена, железа возросли. Вклад автотранспорта в этом городе составляет $69 \%$. Тенденция за период 20102014 гг. нерадужная: среднегодовые концентрации аммиака возросли.

В г. Тынде основные источники загрязнения атмосферы - котельные и городской автотранспорт (33\%).

Концентрации диоксида азота: среднегодовая составляет 1,1 ПДК, максимальная не превышает 1 ПДК.

Концентрации оксида углерода: среднегодовая ниже 1 ПДК, максимальная из разовых проб в 1,4 раза превышает ПДК. Загрязнение бензапиреном по сравнению с предыдущим годом понизилось. Среднегодовое содержание данной примеси составляет 0,6 ПДК (в 2013 г. - 1,5 ПДК). Максимальное из среднемесячных значений в марте в 1,8 раза превышало ПДК. Уровень загрязнения воздуха низкий.

Тенденция за период 2010-2014 гг. такова: среднегодовые концентрации ВВ, оксида углерода, диоксида азота, сажи, формальдегида возросли.

Тенденция за период 2005-2014 гг. неблагополучная: отмечается устойчивое возрастание среднегодовых концентраций вышеперечисленных примесей, за исключением ВВ.

Продолжительный период сухой и тёплой погоды в этой области создали благоприятные условия для повышения класса пожарной горимости, в связи с чем класс пожароопасности достиг высокой степени, соответственно, возросло загрязнение в г. Тынде по ВВ.

Этот регион имеет высокую степень загрязнения атмосферы, так как ПДК по такому опасному поллютанту, как бензапирен превышалась в 20,2 раза.

Еврейская автономная область [2]. Численность её населения 160 тыс. человек (2018 г.). Здесь значительный вклад в загрязнение атмосферного воздуха вносит ТЭК, обрабатывающие производства, предприятия по добыче полезных ископаемых, автотранспорт (сл. табл. 1).

Город Биробиджан. В нём основной вклад в выбросы от стационарных источников вносят Биробиджанская ТЭЦ, завод силовых трансформаторов, а также предприятия ЖКХ. В 2016 г. объём выбросов от стационарных источ- 
ников составил здесь 9,3 тыс. т. Вклад автотранспорта в суммарный выброс по области составляет 42 \%. За период 2012-2016 г. наблюдается увеличение среднегодовых концентраций ВВ и диоксида азота.

В 2016 г. в воздухе было выявлено 3 случая превышения ПДК по ВВ (до 1,2 раза). Загрязнение бензапиреном, по сравнению с 2015 г., снизилось. Его среднемесячное содержание в апреле составило 0,6 ПДК, в мае повысилось до 1,1 ПДК, в июне и июле снизилось до 0,6 ПДК, в сентябре данный показатель составил 0,5 ПДК, в октябре - 1,4 ПДК, в ноябре - 4,5 ПДК (тенденция роста к холодному сезону очевидна). Средняя за год величина загрязнения в 2016 г. составляла 6,7 ПДК (в 2015 г. - 7,2 ПДК). По сравнению с предыдущим годом загрязнение бензапиреном снизилось.

Этот регион имеет среднюю степень антропогенной нагрузки.

Сахалинская область [6]. Её численность населения 490 тыс. человек $(2018$ г.). Этот регион является единственным островным в РФ. Он в наименьшей степени страдает от трансграничных влияний и пожаров, но в наибольшей степени - от загрязнения развитой здесь нефртегазодобычи. В г. Южно-Сахалинске основные источники загрязнения - ТЭК, предприятия рыбной промышленности и ЖКХ. Среднегодовая концентрация диоксида азота составляет 2,2 ПДК, наибольшая 2,9 ПДК. Среднегодовая концентрация ВВ не превышает уровень 1 ПДК. Максимальная из среднесуточных концентраций 3,4 ПДК. Среднегодовая концентрация оксида углерода не превышает ПДК. Максимальная из разовых концентраций достигала величины 3 ПДК. Среднегодовая концентрация бензапирена соответствует значению 2,6 ПДК. Максимальная из среднемесячных концентраций $(8,8$ ПДК) отмечена в декабре.

Среднегодовая концентрация сажи не превышает допустимого значения, а максимальная 4,5 ПДК. Среднегодовая концентрация фрормальдегида соответствует значению 1,7 ПДК (максимальная - 2,4 ПДК). Загрязнение воздуха высокое. Наблюдается увеличение среднегодовых концентраций и по формальдегиду.

За пятилетний период (2013-2017 гг.) наблюдается устойчивая тенденция изменения концентраций загрязняющих веществ. Среднегодовые концентрации диоксида серы и сероводорода снизились на $50 \%$, сажи - на 75 \%, произошло также снижение концентраций хрома, цинка, свинца, никеля, марганца, за исключением меди и железа. Заметим, что Южно-Сахалинск неоднократно фигурировал в списках докладов самых загрязненных городов РФ.

В г. Охе основные источники загрязнения атмосферы - предприятия недтяной и газовой промышленности, аэропорт, ЖКХ. Средняя за год концентрация диоксида азота соответствует уровню 1,2 ПДК. Среднегодовая концентрация ВВ составляет 0,6 ПДК (максимальная 2,7 ПДК).

В г. Александровске-Сахалинском основные источники загрязнения атмосреры - предприятия добывающей и энергетической промышленности, ЖКХ. Средний уровень запыленности воздуха ниже уровня ПДК. Максимальная из среднесуточных концентраций ВВ соответствует значению 1,3 ПДК. Среднегодовая концентрация сажи соответствует значению 1,4 ПДК (максимальная - 3,4 ПДК).

В г. Поронайске основные источники загрязнения атмосферы - предприятия рыбной промышленности, ЖКХ, а также рыбного фрлота. Здесь среднегодовые концентрации ВВ и диоксида серы снизились на 56 \% и 50 \% соответственно, концентрации диоксида азота выросли на 30,8\%. Средний уровень загрязнения воздуха города не превышает ПДК. Максимальная из среднесуточных концентраций составила 2,7 ПДК. Среднегодовая концентрация сажи соответствует значению 1,5 ПДК. Максимальная из разовых достигает величины 2,7 ПДК. За 2013-2017 гг. среднегодовые концентрации диоксида азота снизились на 36,7 \%, концентрации сажи возросли на 76,2 \%, диоксида серы на 50 \%. ТЭК этого региона нуждается в значительной модернизации: парадокс его проблемы заключается в том, что при значительной добыче в нём газа многие устаревшие котельные до сих пор работают на угле.

В целом Сахалинская область имеет повышенный уровень загрязнения атмосферы, особенно по саже - до 3,4 ПДК. 
Камчатский край [3]. Его население составляет 314 тыс. человек. Здесь основными источниками антропогенного загрязнения приземного слоя атмосферы являются ТЭК и автотранспорт: на долю последнего в 2017 г. пришлось 58,4 \% от суммарных фрактических выбросов. При этом в 2017 г., по сравнению с 2016 г., наблюдалось увеличение выбросов загрязняющих веществ в атмосdеру от стационарных источников на 33,2 \%. Значительный вклад в загрязнение воздуха вносят парогазовые и пепловые выбросы действующих вулканов. Лесные пожары в теплый период года могут охватывать тысячи гектаров.

В г. Петропавловске-Камчатском наибольшее загрязнение ВВ отмечалось в июне, когда его средние и разовые концентрации превышали ПДК по всем пунктам наблюдений, но в большей степени в центральном районе - в 1,4 и 4,6 раза соответственно. Загрязнение воздуха диоксидом азота в среднем по городу за год было небольшим - 0,6 ПДК, но по отдельным районам, в частности центральному и северному, оно превысило допустимое значение - 1,1 и 1,4 ПДК соответственно. Среднегодовая концентрация диоксида азота составляла 0,7 ПДК, а среднемесячная превысила санитарную норму в 1,2 раза (максимальное - 1,6 ПДК). Среднегодовое содержание формальдегида превысило ПДК в 1,5 раза. Среднегодовое содержание оксида азота, как и годом ранее, превышало средний показатель загрязнения атмосферы в городах Азиатской части РФ на 83 \%. В среднем за пятилетний (2013-2017 гг.) период концентрации диоксида серы, оксида и диоксида азота, оксида углерода, формальдегида и бензапирена снизились, содержание фенола осталось без изменений. В 2017 г. резко возросло среднегодовое значение ВВ.

В г. Елизово загрязнение формируется в основном автотранспортом и котельными за счет присутствия в атмосфере ВВ (максимальное - 2,6 ПДК) и диоксида азота (1,1 ПДК), величины остальных определяемых поллютантов были значительно ниже.

Камчатка имеет свои парадоксы в решении энергетической проблемы. Еще в 1983 г. на ее западном побережье было открыто крупное газоконденсатное месторождение, однако только в 2010 г. завершилось строительство газопровода от него до Петропавловск-Камчатского и начался перевод ТЭЦ этого города на газ. В энергетике края в XXI в. произошли заметные структурные изменения: к ранее построенной в 1966 г. маломощной Паужетской геотермальной электростанции, в 2003 г. была введена в эксплуатацию более мощная Мутновская ГеоТЭС, которая в 2018 г. вышла на проектную мощность, взяв на себя до 30 \% выработки электроэнергии края. Таким образом, на Камчатке все более активно используются альтернативные источники - подземное тепло вулканов.

В целом Камчатский край имеет низкий уровень загрязнения.

Магаданская область [4]. Ее население составляет 141 тыс. человек (2018 г.). Основные источники выбросов представлены многочисленными предприятиями горнодобывающей промышленности, в меньшей степени котельными и автотранспортом. В г. Магадане в связи с изменением ПДК фенола и формальдегида средние концентрации, с учетом старых ПДК, составляли 1,4 ПДК и 3,4 ПДК, максимально разовые 3,2 ПДК и 6 ПДК соответственно. С учетом новых ПДК средняя за год и максимальная разовая концентрации френола достигали 0,7 и 3,2 ПДК, формальдегида - 1 и 1,2 ПДК, соответственно. Следует учитывать, что состояние загрязнения атмосфреры с 2014 г. не изменилось по сравнению с предыдущими периодами. Среднегодовая концентрация бензапирена была равна 1 ПДК, максимальная достигала 2 ПДК. Средняя за год концентрация оксида углерода была менее 1 ПДК, максимальная разовая концентрация достигала 1,4 ПДК. Средние концентрации железа, марганца никеля и цинка выше средних концентраций по городам России за 2014 г. Уровень загрязнения воздуха оценивался как низкий.

Чукотский автономный округ [8]. Этот субъект является самым малонаселенным (49,7 тыс. человек на 2018 г.) и наименее освоенным в хозяйственном отношении на ДВ. На данной территории наблюдения проводились в г. Анадырь и г. Певек. Основными загрязнителями атмосферного воздуха в округе по валовому выбросу являются энергетика, предприятия по добыче золота, серебра и меди, ЖКХ и портов (перевалка угля). Стационарными источниками было выброшено в атмосферу 21,6 тыс. т. Объем выбросов от автотранспорта - 4,9 тыс. т. Эти показатели снизятся, так как в 2019 г. сюда 
была направлена по Северному морскому пути самая современная плавучая атомная әнергетическая установка "Михаил Ломоносов ". С сентября 2019 г. она пришвартовалась в Певеке для подключения его и пос. Билибино к их тепло- и энергоснабжению.

Из этих цифр следует, что данный субъект характеризуется среди других самыми низкими показателями выбросов по ДВ (сл. табл. 1), а, следовательно, и небольшим загрязнением атмосферы.

Сравнительный анализ, проведенный специалистами Гидрометеослужбы [5] по суммарному объему выбросов и сбросов загрязняющих веществ в воздух и водные объекты, а также отходов производства и потребления по всему ДВ был отражен в интегральной экологической нагрузке, которая составила максимальное значение в Приморском крае - 2800 т/км², в Сахалинской области - 817 т/км ${ }^{2}$, в Еврейской автономной области - 327 т/км ${ }^{2}$, в Хабаровском крае - 296 т/км². В других субъектах, которые расположены севернее, эти значения заметно ниже.

\section{Заключение}

В результате анализа и обобщения собранных нами материалов установлены следующие особенности состояния атмосферного воздуха ДВ:

1) Трансграничному загрязнению, преимущественно со стороны Китая, подвержена южная часть региона, причем в наибольшей степени Приморский край, лидирующий также по интегральному удельному загрязнению;

2) Лесные пожары охватывают все субъекты ДВ, но в наибольшей степени самый залесённый Хабаровский край;

3) Комбинированное загрязнение, когда воздух насыщен наибольшим количеством токсичных поллютантов, более всего характерно для самых крупных промышленно развитых городов региона - Хабаровска и Владивостока;

4) Из всех поллютантов наиболее распространенным является пыль (BВ), но, в зависимости от ее происхождения (от сгорания топлива, переноса ветром с угольных терминалов или от цементных заводов), она по разному воздействует на организм человека;

5) Высокий темп автомобилизации региона и заметная концентрация в воздухе ПАУ даёт основание рекомендовать Гидрометеослужбе включить их в общий перечень анализируемых поллютантов;

6) Среди стационарных источников загрязнения на первом месте по выбросам лидирует ТЭК, вот почему его модернизация, которая с разным темпом происходит во всех субъектах региона, является весьма актуальной;

7) Среди мобильных источников загрязнения лидирует автотранспорт, но его перевод на газомоторное топливо, а также внедрение электромобилей происходит крайне медленно.

\section{Литература}

1. Доклад о состоянии окружающей среды в Амурской области в 2017 году. Благовещенск: Министерство природных ресурсов и экологии Амурской области, 2018. $133 \mathrm{c}$.

2. Доклад о состоянии окружающей среды в Еврейской автономной области в 2017 году. Биробиджан: Министерство природных ресурсов и экологии Еврейской автономной области, 2018. 140 c.

3. Доклад о состоянии окружающей среды в Камчатском крае в 2017 году. Петропавловск-Камчатский: Министерство природных ресурсов и экологии Камчатского края, 2018. 378 с.

4. Доклад о состоянии окружающей среды в Магаданской области в 2015 году. Магадан: Министерство природных ресурсов и экологии Магаданской области, 2016. $181 \mathrm{c.}$

5. Доклад о состоянии окружающей среды в Приморском крае в 2017 году. Владивосток: Департамент природных ресурсов и экологии Приморского края, 2018. 208 с.

6. Доклад о состоянии окружающей среды в Сахалинской области в 2017 году. Южно-Сахалинск: Министерство природных ресурсов и экологии Сахалинской области, 2018. 177 с.

7. Доклад о состоянии окружающей среды в Хабаровском крае в 2017 году. Хабаровск: Министерство природных ресурсов и экологии Хабаровского края, 2018. 202 с. 
8. Доклад о состоянии окружающей среды в Чукотском автономном округе в 2017 году. Анадырь: Министерство природных ресурсов и экологии Чукотского автономного округа, 2018. 117 с.

9. Долговременная программа охраны природы и рационального использования природных ресурсов Приморского края до 2005 года. Экологическая программа. Часть 2. Владивосток: Дальнаука, 1993. 301 с.

10. Ивашинников Ю. К. Физическая география Дальнего Востока России. Владивосток: Изд-во Дальневост. ун-та, 1999. 324 с.

11. Кику П. Ф., Гельцер Б. И. Экологические проблемы здоровья. Владивосток: Дальнаука, 2004.228 c.

12. Наумов Ю. А. Особенности, тенденции и последствия загрязнения атмосферы городов Приморского края / Территория новых возможностей. Вестник ВГУЭС, Владивосток, 2014. С. 157-173.

13. Пискунов Ю. Г., Потапенко О. В., Зубов К. Г. Источники загрязнения в г. Артем и пути улучшения ситуации // Мат-лы Междунар. науч. чтений "Приморские зори - 2009". Владивосток: Изд-во ТАНЭБ. Вып. 2, 2009. С. 143-146.

14. Раковская Э. М., Давыдова М. И. Физическая география России: Учебник. Ч. 1. М.: Гуманит. изд. цетр ВЛАДОС, 2001. 288 с.

15. Сойфер В. Н. Радиоэкология северного шельфа Японского моря. Владивосток: Дальнаука, 2002. $254 \mathrm{c.}$

16. Царева А. Тепло в каждый дом // Аргументы и фракты. № 36. 2019. С. 19.

17. Шаров П. О. Оценка уровня свинца в крови детей пос. Рудная Пристань // Мат-лы Междунар. науч. чтений "Приморские зори - 2003". Владивосток: ТАНЭБ, Вып. 2, 2003. С. 142-146.

\section{Транслитерация по ГОСТ 7.79-2000 Система Б}

1. Doklad o sostoyanii okruzhayushhej sredy v Amurskoj oblasti v 2017 godu. Blagoveshhensk: Ministerstvo prirodnykh resursov i ehkologii Âmurskoj oblasti, 2018. $133 \mathrm{~s}$.

2. Doklad o sostoyanii okruzhayushhej sredy v Evrejskoj avtonomnoj oblasti v 2017 godu. Birobidzhan: Ministerstvo prirodnykh resursov i ehkologii Evrejskoj avtonomnoj oblasti, 2018. $140 \mathrm{~s}$.

3. Doklad o sostoyanii okruzhayushhej sredy v Kamchatskom krae v 2017 godu. Petropavlovsk-Kamchatskij: Ministerstvo prirodnykh resursov i ehkologii Kamchatskogo kraya, 2018. $378 \mathrm{~s}$.

4. Doklad o sostoyanii okruzhayushhej sredy v Magadanskoj oblasti v 2015 godu. Magadan: Ministerstvo prirodnykh resursov i ehkologii Magadanskoj oblasti, 2016. $181 \mathrm{s.}$

5. Doklad o sostoyanii okruzhayushhej sredy v Primorskom krae v 2017 godu. Vladivostok: Departament prirodnykh resursov i ehkologii Primorskogo kraya, 2018. $208 \mathrm{~s}$.

6. Doklad o sostoyanii okruzhayushhej sredy v Sakhalinskoj oblasti v 2017 godu. Yuzhno-Sakhalinsk: Ministerstvo prirodnykh resursov i ehkologii Sakhalinskoj oblasti, 2018. $177 \mathrm{~s}$.

7. Doklad o sostoyanii okruzhayushhej sredy v Khabarovskom krae v 2017 godu. Khabarovsk: Ministerstvo prirodnykh resursov i ehkologii Khabarovskogo kraya, 2018. 202 s.

8. Doklad o sostoyanii okruzhayushhej sredy v Chukotskom avtonomnom okruge v 2017 godu. Anadyr': Ministerstvo prirodnykh resursov i ehkologii Chukotskogo avtonomnogo okruga, 2018. $117 \mathrm{~s}$.

9. Dolgovremennaya programma okhrany prirody i ratsional'nogo ispol'zovaniya prirodnykh resursov Primorskogo kraya do 2005 goda. Ehkologicheskaya programma. Chast' 2. Vladivostok: Dal'nauka, 1993. $301 \mathrm{~s}$.

10. Ivashinnikov Yu. K. Fizicheskaya geografiya Dal'nego Vostoka Rossii. Vladivostok: Izd-vo Dal'nevost. un-ta, 1999. 324 s.

11. Kiku P. F., Gel'tser B. I. Ehkologicheskie problemy zdorov'ya. Vladivostok: Dal'nauka, 2004. $228 \mathrm{~s}$

12. Naumov Yu. A. Osobennosti, tendentsii i posledstviya zagryazneniya atmosfery gorodov Primorskogo kraya / Territoriya novykh vozmozhnostej. Vestnik VGUEHS, Vladivostok, 2014. S. 157-173.

13. Piskunov Yu. G., Potapenko O. V., Zubov K. G. Istochniki zagryazneniya v g. Artem i puti uluchsheniya situatsii // Mat-ly Mezhdunar. nauch. chtenij "Primorskie zori - 2009". Vladivostok: Izd-vo TANEHB. Vyp. 2, 2009. S. 143-146.

14. Rakovskaya Eh. M., Davydova M. I. Fizicheskaya geografiya Rossii: Uchebnik. Ch. 1. M.: Gumanit. izd. tsetr VLADOS, 2001. 288 s.

15. Sojfer V. N. Radioehkologiya severnogo shel'fa Yaponskogo morya. Vladivostok: Dal'nauka, 2002. $254 \mathrm{~s}$.

16. Tsareva A. Teplo v kazhdyj dom // Argumenty i fakty. № 36. 2019. S. 19. 
17. Sharov P. O. Otsenka urovnya svintsa v krovi detej pos. Rudnaya Pristan' // Matly Mezhdunar. nauch. chtenij "Primorskie zori - 2003". Vladivostok: TANEHB, Vyp. 2, 2003. S. $142-146$.

Наумов Ю. А. Об особенностях загрязнения атмосферного воздуха на территории Дальнего Востока России.

Статья посвящена изучению особенностей загрязнения атмосферного воздуха в каждом субъекте Дальнего Востока России. Автор акцентирует внимание на экологическом состоянии городов, увеличении степени загрязнения региона от возрастающей автомобилизации, лесных пожаров и трансграничного воздействия со стороны бурно развивающегося Китая.

Ключевые слова: атлосфберное загрязнение, антропогенное воздействие, поллютанты, экологическая обстановка

Naumov Yu. A. On the features of air pollution in the Russian Far East.

The article is devoted to studying the features of air pollution in each subject of the Russian Far East. The author focuses on the ecological state of cities, increasing the degree of pollution in the region from increasing motorization, forest fires and transboundary impact from the booming China. situation

Key words: atmospheric pollution, anthropogenic impact, pollutants, ecological

Для цитирования: Наумов Ю. А. Об особенностях загрязнения атмосферного воздуха на территории Дальнего Востока России // Ойкумена. Регионоведческие исследования. 2020. № 1. C. 41-52. DOI: 10.24866/1998-6785/2020-1/41-52

For citation: Naumov Yu. A. On the features of air pollution in the Russian Far East // Ojkumena. Regional researches. 2020. № 1. P. 41-52. DOI: 10.24866/1998-6785/2020-1/4152 


\section{Исследование миграционных процессов в современной России с позиции обеспечения экономической безопасности}

\section{Постановка проблемы}

В условиях глобализации масштабы миграции сильно возросли. Современная мировая наука всесторонне изучает эти процессы. Большой вклад в изучение мотивов, масштабов, направлений и последствий массового перераспределения населения внесли зарубежные ученые - представители разных наук: В. Зелински [35], Д. Массей [30], Э. С. Ли [29] другие.

Предметом изучения в данной статье стала экономическая сторона миграционных процессов. Современные исследователи миграционных потоков подчеркивают их явно выраженную ориентацию из периферии в центр (из развивающихся стран в развитые государства), отмечают, что миграция способствует размыванию границ и ослаблению суверенитета государств [31].

Современной ситуации в сфере миграции и влиянию процессов глобализации на активность территориальной мобильности населения посвящены работы экономистов С. Сассен [33; 34], С. Каслса, М. Миллера [25], Д. Харриса, М. Тодаро [28] и других известных ученых.

Джон Харрис и Майкл Тодаро исследовали взаимное влияние миграционных процессов и ситуации на рынке труда [28].

Другой теоретик миграции Эверетт С. Ли, развивая концепцию Э. Г. Равенштайна, отмечал, что с местом прибытия и выбытия связаны как позитивные, так и негативные фракторы. $К$ первым он, в частности, относит, стремление воссоединиться с семьей, повысить качество жизни своей семьи и др., а к негативным обстоятельствам, сказывающимся на принятии решения о смене места жительства, - многочисленные проблемы, с которыми сталкиваются люди при переезде [29].

Каждая страна имеет свои особенности в развитии процессов миграции. Изучению миграции в России посвящены работы Н. В. Парикова [13], Л. Л. Рыбаковского [17], О. Л. Рыбаковского [18], С. В. Рязанцева [19] и других отечественных ученых.

В последнее время проблемы миграции все чаще связывают с экономической безопасностью страны. Влияние массовых перемещений населения на экономическое развитие исследуют в своих работах Х. М. Вахаев [1], В. А. Волох [2], Т. М. Гаврилова [3], Н. В. Дементьев [4] и другие ученые.

Исследованию рассматриваемых проблем на региональном уровне посвящены работы Л.Н.Липатовой, В. Н. Градусовой [3], Н. А. Пруеля [14], С. С. Фешиной [21], М. Ю. Хавинсона, М. П. Кулакова, С. Н. Мищука [22], В. С. Цырюльникова [23], И. А. Юрасова, О. А. Лузгиной, В. Д. Дорофреева [25].

Однако под воздействием многих причин ситуация быстро меняется. Теоретические представления тоже нередко расходятся с реальной картиной. Так, согласно неоклассической экономической теории, оказавшей сильное влияние на теорию миграции, мигрировать должны беднейшие люди в богатейшие страны, на практике же большую часть миграционного потока формируют представители среднего класса развивающихся стран [27].

Противоречит неоклассической теории, опирающейся на постулат, что человек старается рационализировать свое поведение, максимизировать ре-

\footnotetext{
(C) Липатова Л. Н., 2020
}

ЛИПАТОВА Людмила Николаевна, д-р социол. наук, канд. экон. наук, доцент, продессор кафедры әкономики Северо-Западного института управления РАНХиГС (г. Санкт-Петербург). E-mail: ln.lipatova@yandex.ru 
зультат с минимальными затратами, и изменение направления миграции из России в пользу таких стран, как Китай, Индия, КНДР, для успешной адаптации в которых мигрантам потребуется приложить гораздо больше усилий, чем в случае переезда в благополучную европейскую страну.

Не всегда удается предсказать последствия миграционных перемещений. Ситуация в европейских странах, столкнувшихся с проблемой миграции, наглядно это подтверждает. Миграция может как способствовать прогрессу общества, так и нанести урон экономике страны, поставить под угрозу социальную стабильность и вызвать изменения политическом характера, что может серьезно затруднить продвижение государства по пути устойчивого социально-экономического развития.

Ограничивать перемещения людей между странами, как показывает опыт европейских стран, испытывающих приток мигрантов из стран Азии и Африки, сложно, а внутри страны нельзя. Но при разработке социальноэкономической политики необходимо учитывать направления и масштабы миграции, состав мигрантов, чтобы предотвратить или минимизировать те негативные последствия, к которым могут привести массовые перемещения людей.

Это делает необходимым проведение детальных исследований в практической плоскости. Основная цель данного исследования - провести анализ миграционных потоков в современной России и выявить связанные с миграцией населения угрозы экономической безопасности и социальной стабильности.

При проведении исследования источниками инфрормации послужили данные Федеральной службы государственной статистики, ее территориальных органов, а также экспертные оценки специалистов. Исследование проводилось с использованием системного подхода, методов демографического анализа, обобщения и интерпретации полученных результатов.

\section{Современная ситуация:}

\section{экономико-статистический анализ и экспертные оценки}

Территориальная мобильность россиян в последние годы значительно усилилась. Это касается как международной миграции, так и перераспределения населения внутри страны. Миграционный прирост в РФ не вызывает никаких опасений. Более того, в стране реализуются государственные программы по привлечению на территорию России граждан других государств.

В России существует другая проблема, связанная с перемещением населения, - эмиграция, способная нанести значительный урон человеческому потенщиалу страны, а значит, и ограничить возможности развития. Хотя масштабы миграции из России незначительны и в основном поток выбывающих представлен иностранными гражданами (более 80 \% в 2016 г.), следует обратить внимание на значительный и быстрый прирост численности покинувших страну россиян - за 7 лет этот показатель увеличился почти в два раза (табл. 1).

В 2016 г. РФ наиболее активный обмен населением осуществляла со следующими государствами дальнего зарубежья: Китаем (14\% совокупного оборота миграции со странами дальнего зарубежья), КНДР (11 \%), Грузией (9 \%), Германией (7 \%), Индией (7 \%), Вьетнамом (6 \% совокупного оборота миграции со странами дальнего зарубежья) [5] .

Положительным сальдо миграции было в 2016 г. только в обмене со следующим странами дальнего зарубежья: Абхазией, Афганистаном, Болгарией, Вьетнамом, Грузией, Индией, КНДР, Латвией, Литвой, Сирийской Арабской Республикой, Турцией, Эстонией.

Анализируя структуру миграционного потока, следует обратить внимание на такие новые и вместе с тем активно развивающиеся направления, как Китай, КНДР, Индия, Вьетнам. Учитывая языковую специфику данных направлений и темпы нарастания обмена (совокупный миграционный оборот по этим 4 странам в 2010 - 2016 гг. возрос более чем в 16 раз), можно предположить, что осваивает их в основном молодежь.

Именно это обстоятельство и вызывает особое беспокойство. Эта возрастная категория, как правило, легко адаптируется к новым условиям. Более того, современная молодежь проявляет склонность к экзотике и экстриму. 
Таблица 1. Распределение численности выбывших из Российской Федерации по гражданству

\begin{tabular}{|c|c|c|c|c|c|c|c|c|}
\hline \multicolumn{2}{|c|}{ Гражданство } & $\mathbf{2 0 1 0}$ & $\mathbf{2 0 1 1}$ & $\mathbf{2 0 1 2}$ & $\mathbf{2 0 1 3}$ & $\mathbf{2 0 1 4}$ & $\mathbf{2 0 1 5}$ & $\mathbf{2 0 1 6}$ \\
\hline \multicolumn{2}{|c|}{ Выбывшие из Российской Федерации, всего } & 33578 & 36774 & 122751 & 186382 & 308475 & 353233 & 313210 \\
\hline \multirow{3}{*}{$\begin{array}{l}\text { в том } \\
\text { числе: }\end{array}$} & граждане России & 31734 & 29467 & 46687 & 47439 & 53235 & 51846 & 58739 \\
\cline { 2 - 9 } & из них имеют второе гражданство & 1512 & 291 & 577 & 625 & 867 & 903 & 1112 \\
\cline { 2 - 10 } & иностранные граждане & 1477 & 6755 & 74582 & 137329 & 251768 & 298257 & 250840 \\
\hline
\end{tabular}

Источник: составлено на основе [5].

Многие из современных молодых людей знают несколько языков, особый интерес проявляют к восточным языкам.

Эксперты считают, что угрозу нашей стране сегодня представляет так называемая "утечка умов". В мировой конкурентной борьбе за высоко квалифицированные кадры Россия уступает странам Запада. Есть данные, что за 2000-2014 гг. из РФ уехало от 1,5 до 1,8 млн чел. [24].

Исследования показывают, что все больше людей с высшим образованием уезжает из России. В докладе "Квалифицированная миграция в России: баланс потерь и приобретений" говорится, что, по данным Росстата, в 2015 г. из России уехали 51,8 тыс. граждан, а в 2016 г. - около 60 тыс. чел. Но авторы доклада утверждают, что официальные данные сильно занижены. Согласно миграционной статистике иностранных государств, ежегодно из России эмигрируют около 100 тыс. чел. В настоящее время за рубежом живут около 2,7 млн уроженцев России, из них 1,5 млн чел. имеют российское гражданство.

Около трети эмигрантов из России едут учиться в магистратуру или аспирантуру, еще треть - работать. Половина трудовых иммигрантов в Европе находятся там по "голубой карте" для квалифицированных специалистов. Некоторые переезжают за рубеж для воссоединения с семьей.

По данным Росстата, в 2016 г. в зарубежные страны из России выехали 313210 граждан, 82,3 \% из них - в трудоспособном возрасте. Среди прибывших в страну мигрантов удельный вес этой возрастной категории составил 77,8 \%. Особое беспокойство вызывает отток молодежи - на долю возрастной категории 15-29 лет приходилось 34 \% выбывших из нашей страны в этом году. Среди прибывших молодых людей было 33 \% [5].

Исследования Росстата доказывают, что многие из уехавших хорошо образованны - доля таких людей в общем потоке эмиграции составляет от 30 до 70 \% в зависимости от принимающей страны. Данные зарубежных стран и результаты интервью с эмигрантами свидетельствуют, что последние годы наблюдается рост квалифицированной эмиграции из России - в среднем 40 \% переехавших из России на Запад имеют высшее образование. Общая численность образованных российских эмигрантов - около 800 тыс. чел.

Авторы названного выше доклада подчеркивают, что, несмотря на действующую уже много лет программу привлечения квалифицированных иностранных кадров, миграция в Россию не компенсирует отток высококвалифицированных специалистов. Образованных людей в страну приезжает меньше, чем уезжает. И даже если у мигранта есть должное образование, вероятнее всего, он сможет устроиться только на не требующую никакой квалификации работу [20].

Специалисты РАН отмечают, что за последние три года наблюдается рост эмиграции из страны высококвалифицированных специалистов. По словам главного ученого секретаря президиума РАН, только с 2013 по 2016 гг. количество уехавших увеличилось с 20 тыс. до 44 тыс. чел. При этом многие российские научные организации испытывают нехватку кадров. Так, в институтах Федерального агентства научных организаций за последние три года численность ученых сократилась с 69,5 до 67 тыс. чел. Кроме того, каждый третий ученый в России достиг пенсионного возраста. 
А уезжает из страны в основном талантливая молодежь. Исследования ученых из МГУ им. М. В. Ломоносова так характеризуют современные тенденции миграции и настроения российской молодежи: только 30 \% студентов твердо заявили, что ни при каких обстоятельствах не уедут из страны. Первое место среди причин, побуждающих к трудовой миграции, занимают доходы. Около 40 \% из числа тех, кто не уехал, но теоретически допускают такую возможность, говорили о том, что их не устраивает перспектива низкого уровня жизни.

Среди значимых причин, побуждающих к отъезду, также фригурировали невозможность реализовать собственный творческий потенциал. У многих, кто уехал, не было никакого опыта работы или имелся минимальный. Современные молодые люди амбициозны и хотят сразу заниматься тем, что им интересно и принесет желаемый доход. Респондентами отмечались еще два важных фрактора, которые подталкивают уехать из страны, - это политическая нестабильность и недостаточный уровень экономической свободы. На это указывали примерно 40 \% участников данного опроса.

Среди эмигрировавших респондентов каждый второй отметил, что окончил бакалавриат с отличием. Лишь 8 из 84 чел. указали, что успеваемость во время обучения была низкой. Среди выпускников, не совершавших эмиграции, отличную учебу отмечала существенно меньшая часть респондентов $-32 \%$. То есть, чем выше человеческий капитал, тем больше вероятность отъезда.

Исследования выявили еще одну закономерность - студенты, которые участвовали в программах обмена с зарубежными вузами или проходили когда-то практику за рубежом, чаще выражали готовность уехать. Не менее 36 \% эмигрировавших участвовали в подобных программах.

Выпускники экономического фракультета МГУ им. М. В. Ломоносова чаще всего переселяются в США (более 1/4), затем в порядке убывания следуют Германия, Великобритания, Нидерланды. Большая часть эмигрировавших выпускников МГУ им. М. В. Ломоносова в эмиграции работают по полученной на родине специальности. Но участники опроса признались, что, если потребуется, они готовы сменить профрессию, но остаться в стране пребывания.

Исследование специалистов МГУ им. М. В. Ломоносова также показывает, что уехавшие поддерживают со страной исхода очень слабые отношения. Общаются в основном с самыми близкими, профессиональных вопросов, как правило, не затрагивают.

Некоторые участники опроса (6\% респондентов) также сообщили, что деньги переводят редко и суммы таких переводов незначительны (как правило, не более 100 долларов). При этом признались, что, посещая родину в качестве туристов, не скупятся (приобретают билеты на транспорт, в театры, музеи, ходят в магазины и т. п.) [8].

Серьезную угрозу нащиональной безопасности России представляет не только прямая потеря интеллектуальных ресурсов вследствие миграции, но и связанное с этим возможное снижение общего уровня образования в стране. Ученые уезжают из страны, потому что недостаточно финансируются школы, университеты и проведение научных исследований, а социальный статус и уровень оплаты труда ученых в России остаются невысокими.

Ученые отмечают, что опасность для России заключается и в оттоке за рубеж предпринимателей, в которых так остро нуждается наша экономика $[6,7]$. К принятию такого решения в пользу западных стран для этой категории мигрантов склоняет: стабильное и прозрачное законодательство, низкий уровень коррупции, простота открытия бизнеса, более высокая доступность кредитных ресурсов, широкие возможности найти инвесторов для своих бизнес-проектов. Как показали результаты опроса, проведенного в мае 2017 г. московской компанией "Агентство Контакт", среди 467 топ-менеджеров российских и международных фрирм, в ближайшие два года каждый шестой его участник намеревается уехать в другую страну. Большинство хотят жить в США, Германии или Великобритании.

Перемещениям людей воспрепятствовать нельзя. Задача государства состоит в том, чтобы изучать имеющийся международный опыт по регулированию миграции и адаптировать его к современным российским условиям. Предотвратить массовый отток специалистов может только четкая государ- 
ственная политика в отношении ученых и высококвалифицированных специалистов.

А для сохранения социальной стабильности и предотвращения конфлликтов на национальной и религиозной почве необходимо при реализации государственной политики учитывать национальную структуру прибывающих в страну мигрантов. По данным статистики, большая их часть приходится на страны СНГ - 88 \% от численности прибывших в Россию в 2016 г. иностранных граждан. Хотя более 37 \% этого потока приходилось на славянские государства Украину и Беларусь, значительная часть прибывших в Россию была представлена гражданами Узбекистана (13\%), Казахстана (12 \%), Таджикистана (11 \%), Армении (8,5 \%) [5]. Это требует разработки и реализащии программы мероприятий по предотвращению конфликтов на межнациональной и межконфессиональной почве.

Если для РФ миграция в целом особой угрозы не представляет, то на уровне регионов перераспределение населения может вызвать разнообразные проблемы. В последние годы перемещения населения внутри страны значительно активизировались. Если в 2010 г. численность внутренних мигрантов не превышала 2 млн чел., то в последние годы их число удвоилось. В 2017 г. более 4 млн россиян сменили место жительства.

Столь масштабное перераспределение населения способно серьезно осложнить управление социально-экономическими системами как регионов-доноров, так и принимающей стороны. Массовый отток населения из региона может негативно сказаться на трудовом потенциале территории. Высокая привлекательность региона для мигрантов ведет к усилению нагрузки на социальную инфраструктуру. Это требует детальных исследований по выявлению основных причин и направлений миграции.

В 2017 г. наибольший вклад в миграционный оборот внес Центральный федеральный округ: на него приходилось 24 \% выбывших и 27 \% прибывших в масштабах страны. Поток выбывающих из регионов ЦФО на $3 / 4$ представлял собой перераспределение населения внутри этого округа. По $6 \%$ переехали в ПФО и СЗФО (табл. 2).

Следующий по объему миграционного обмена федеральный округ - Приволжский. На него в 2017 г. пришлось 19,5 \% выбывших и $18 \%$ прибывших. $71 \%$ выбывших из приволжских регионов остались в пределах ПФО, более $13 \%$ - направились в регионы ЦФО, по 5 \% - в СЗФО и УФО.

$15 \%$ совокупного оборота по выбытию формируют регионы Сибирского ФО. В обороте по прибытию доля этого округа составила в 2017 г. 13,5\%. 76,5 \% выбывших из сибирских регионов остались в пределах СФО, около $7 \%$ - переехали в регионы ЦФО, по $4 \%$ - в СЗФО и ЮФО. В регионы УФО выехали немного более 3 \% выходцев их сибирских регионов.

Мигранты из Северо-Западного ФО тоже в подавляющем большинстве (71\%) остаются в границах федерального округа, 12 \% переселяются в регионы ЦФО, 6 \% - в республики и области ПФО, 4 \% - в южные регионы.

В то время как сами южане стремятся уехать в центральные регионы (более 16 \% в 2017 г.). Еще 6 \% предпочли Северо-Запад, 5 \% - Северный Кавказ, 4 \% - приволжские регионы. Только 60 \% остались в пределах фредерального округа.

$66 \%$ мигрантов из уральских регионов перераспределяются внутри УФО, $11 \%$ переселяются в разные субъекты ПФО, $7 \%$ - в регионы ЦФО, $5 \%$ - в южные регионы, по $4 \%$ на территории СЗФО и СФО.

Выбывающие с территории Дальнего Востока распределились в 2017 г. следующим образом: 67 \% остались в границах ДВФО, 9 \% перебрались в центральные, $7 \%$ - в сибирские, $6 \%$ - южные, $3 \%$ - приволжские регионы страны.

Активнее всего выезжают за пределы своего федерального округа жители Северного Кавказа - в пределах СКФО закрепились в 2017 г. только 50 \% мигрантов. Более 19 \% переселились в регионы ЦФО, 13 \% предпочли ЮФО, $7 \%$ - СЗФО, $5 \%$ - УФО, 3 \% - ПФО.

В результате перераспределения населения Северо-Запад и Центр страны длительный период времени испытывают значительную миграционную нагрузку, сопоставимую с той величиной этого показателя, которая во 
Таблица 2. Межрегиональная миграция населения в Российской Федерации в 2017 г., человек

\begin{tabular}{|c|c|c|c|c|c|c|c|c|c|}
\hline \multirow[b]{2}{*}{$\begin{array}{l}\text { ТЕРРИтория } \\
\text { пРИБЫтия } \\
\text { Территория } \\
\text { Выбытия }\end{array}$} & \multirow[b]{2}{*}{ 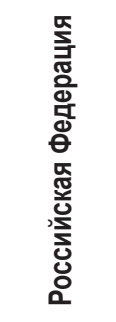 } & \multicolumn{8}{|c|}{ В федеральные округа } \\
\hline & & 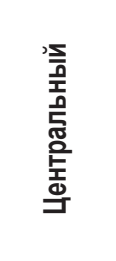 & 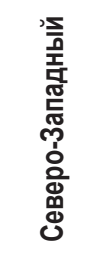 & 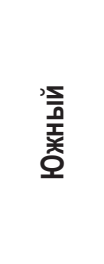 & 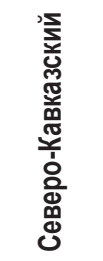 & 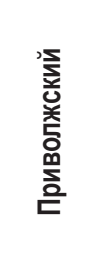 & 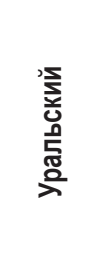 & 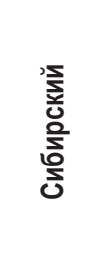 & 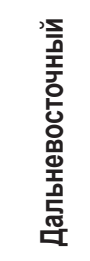 \\
\hline $\begin{array}{l}\text { Российская } \\
\text { Федерация }\end{array}$ & 4184467 & 1125740 & 564395 & 418150 & 167853 & 752440 & 370516 & 563849 & 221524 \\
\hline \multicolumn{10}{|c|}{ Из федеральных округов } \\
\hline Центральный & 1000837 & 758629 & 59313 & 47056 & 21663 & 64050 & 16907 & 21217 & 12002 \\
\hline $\begin{array}{l}\text { Северо- } \\
\text { Западный }\end{array}$ & 519324 & 62731 & 366466 & 22729 & 8915 & 28839 & 9619 & 12323 & 7702 \\
\hline Южный & 400777 & 65873 & 25488 & 242029 & 19452 & 15084 & 12510 & 12042 & 8299 \\
\hline $\begin{array}{l}\text { Северо- } \\
\text { Кавказский }\end{array}$ & 196911 & 38222 & 13848 & 24744 & 98596 & 5835 & 9060 & 4146 & 2460 \\
\hline Приволжский & 814535 & 109435 & 41224 & 22426 & 5238 & 577336 & 42514 & 9964 & 6398 \\
\hline Уральский & 390529 & 28663 & 16965 & 20227 & 7574 & 41854 & 256168 & 16087 & 2991 \\
\hline Сибирский & 615664 & 41112 & 25616 & 24066 & 4035 & 11940 & 20329 & 471002 & 17564 \\
\hline Дальневосточный & 245890 & 21075 & 15475 & 14873 & 2380 & 7502 & 3409 & 17068 & 164108 \\
\hline
\end{tabular}

Источник: составлено на основе [16, с. 103].

многих странах мира квалифицируется как угрожающая стабильности или кризисная - 5-7 чел. на 1000 чел. населения (табл. 3).

В некоторых субъектах РФ рассматриваемый показатель гораздо выше, и миграционный прирост сохраняется многие годы. В 2017 г. к числу регионов с наибольшим миграционным приростом относились: г. Севастополь (202 чел. на 10000 чел. населения), Ленинградская область (171 чел.), г. Санкт-Петербург (121 чел.), Московская область (111 чел.), Тюменская область без автономных округов (105 чел.), Калининградская область (99 чел.), г. Москва (89 чел.), Краснодарский край (63 чел.), Сахалинская область (49 чел. на 10000 чел. населения) [15, с. 87-88].

Это создает дополнительную нагрузку на транспортную сеть и социальную инфраструктуру региона (детские сады, школы, больницы и др.), может осложнить деятельность государственных внебюджетных фондов, негативно сказаться на конъюнктуре рынка труда, ухудшить санитарно-эпидемиологическую ситуацию, при определенных обстоятельствах дестабилизировать ситуацию в обществе и привести к возникновению конфликтов на национальной почве, росту преступности и другим негативным последствиям.

Итак, высокая миграционная привлекательность отдельных российских регионов (в первую очередь - г. Севастополя, г. Санкт-Петербурга, г. Москвы, Ленинградской, Московской, Тюменской и Калининградской областей, в которых длительное время фоккируется ежегодный миграционный прирост населения на уровне $1 \%$ и более) делает необходимой разработку программ регионального социально-экономического развития с учетом численности и состава прибывающих в регион мигрантов. Если местное население не почувствует ухудшения ситуации на рынке труда и в социальной сфрере из-за присутствия на своей территории приезжих, а мигранты не будут ощущать на себе не только косых взглядов, но и дискриминационных мер, а смогут на равных с местными жителями пользоваться услугами социальной сферы, зна- 
Таблица 3. Коэффрициенты миграционного прироста, на 10000 человек населения

\begin{tabular}{|l|c|c|c|c|c|c|c|c|}
\hline \multicolumn{1}{|c|}{ Регион } & $\mathbf{2 0 1 0}$ & $\mathbf{2 0 1 1}$ & $\mathbf{2 0 1 2}$ & $\mathbf{2 0 1 3}$ & $\mathbf{2 0 1 4}$ & $\mathbf{2 0 1 5}$ & $\mathbf{2 0 1 6}$ & $\mathbf{2 0 1 7}$ \\
\hline Российская Федерация & 19 & 22 & 21 & 21 & 19 & 17 & 18 & 14 \\
\hline $\begin{array}{l}\text { Центральный } \\
\text { федеральный округ }\end{array}$ & 74 & 56 & 62 & 60 & 56 & 57 & 45 & 51 \\
\hline $\begin{array}{l}\text { Северо-Западный } \\
\text { федеральный округ }\end{array}$ & 51 & 50 & 58 & 72 & 41 & 16 & 41 & 55 \\
\hline Южный федеральный округ & 21 & 43 & 27 & 45 & 34 & 51 & 48 & 27 \\
\hline $\begin{array}{l}\text { Северо-Кавказский } \\
\text { федеральный округ }\end{array}$ & 4 & -34 & -41 & -40 & -21 & -26 & -21 & -26 \\
\hline $\begin{array}{l}\text { Приволжский } \\
\text { федеральный округ }\end{array}$ & -12 & -4 & -6 & -5 & -2 & -8 & -5 & -12 \\
\hline Уральский федеральный округ & -12 & 31 & 19 & 3 & 7 & 3 & 12 & 0,3 \\
\hline Сибирский федеральный округ & -18 & 1 & -4 & -8 & -4 & -5 & -7 & -16 \\
\hline $\begin{array}{l}\text { Дальневосточный } \\
\text { федеральный округ }\end{array}$ & -49 & -28 & -32 & -53 & -40 & -39 & -28 & -28 \\
\hline
\end{tabular}

Источник: составлено на основе [15, с. 87-89].

чит, в регионе реализуется эффрективная политика в отношении мигрантов, не ущемляющая прав коренного населения.

Не менее сложные в управлении проблемы вызывает миграционный отток населения, который в 2017 г. отмечался в 54 регионах РФ. Наиболее активно протекает этот процесс в регионах Дальневосточного ФО. Все входящие в его состав регионы ежегодно (за редким исключением) испытывают потери населения вследствие его механического движения. Наименьшие в РФ значения коэфроциента миграционного прироста длительный период времени характерны для Магаданской области, Еврейской автономной области и Чукотского автономного округа. В 2017 г. значения этого показателя были соответственно равны: - 97, - 119, - 132 человек на 10000 чел. населения.

Большие потери вследствие миграции несет и Северо-Кавказский ФО. Во всех входящих в его состав регионах, за исключением Республики Ингушетия, отмечается миграционная убыль населения. Особенно сильный отток наблюдается из республик Дагестан и Северная Осетия - Алания - значения коэфрфициента миграционного прироста в 2017 г. были соответственно равны - 42 и - 47 чел. на 10000 чел. населения.

Если для Дальнего Востока отток населения - явление неновое, и вызвано оно сложными условиями жизни и хозяйствования, то для республик Северного Кавказа это нетипично. Национальные традиции и семейные связи обычно способствуют закреплению населения. Наблюдаемые изменения в миграционных установках жителей этих регионов подлежат детальному изучению.

Отрицательно влияет миграция на формирование населения в Приволжском и Сибирском федеральных округах. Из-за миграционного оттока страдают большинство приволжских регионов. Исключение составляют Республика Татарстан, Нижегородская и Самарская области. Наиболее сложная ситуация сложилась в Оренбургской области. В 2010-2017 гг. коэффоциент миграционного прироста редко был больше - 40 чел. на 10000 чел. населения. В рассматриваемый период не на много лучше были показатели и в Кировской области.

Миграционный прирост в Красноярском крае, Новосибирской и Томской областях компенсирует значительные миграционные потери других регионов Сибирского ФО. Наибольший исходящий поток в 2010-2017 гг. характерен для Республики Тыва, но отмечается ежегодное снижение его интенсивности: c - 126 чел. на 10000 чел. населения до - 33 чел. на 10000 чел. населения. 
Печальным лидером по коэффициенту миграционного прироста в 2017 г. стал Забайкальский край (-74 чел. на 10000 чел. населения), ежегодно испытывающий большой отток жителей.

В последние годы сильно активизировались перемещения населения из Омской области, в 2017 г. миграционные потери составили 50 чел. на каждые 10000 населения региона.

В Алтайском крае и Республике Бурятия коэффрициент миграционного прироста в 2010-2017 гг. редко был больше - 20 чел. на 10000 чел. населения.

Далеко не все регионы Центральной России, где ситуацию в сфере миграции можно оценить как наиболее благополучную, привлекательны для мигрантов. Значительный миграционный отток практически весь рассматриваемый период отмечался в Брянской, Костромской и Орловской областях.

В Северо-Западном ФО, для которого в целом характерно положительное сальдо миграции, есть регионы, в которых ежегодные миграционные потери превышают 0,5 \% населения - это Архангельская и Мурманская области. А коэфрфициент миграционного прироста в Республике Коми в 2010-2017 гг. не был выше - 100 чел. на 10000 чел. населения (за исключением 2016 г.).

В привлекательном для мигрантов Южном ФО ситуация в регионах сильно различается. Более $1 \%$ населения в среднем теряет ежегодно вследствие миграции Республика Калмыкия. Существенный отток жителей отмечается практически ежегодно и в Волгоградской области.

Итак, миграционный отток населения отмечается в большинстве субъектов РФ (в 2017 г. - в 54 регионах). Наиболее значительную угрозу устойчивому развитию представляет мигращия в следующих российских регионах: Республика Коми, Республика Калмыкия, Магаданская область, Еврейская автономная область, Чукотский автономный округ (ежегодные миграционные потери превышают 1 \% населения).

Сильное негативное влияние на формирование населения и трудовых ресурсов оказывает миграция в следующих российских регионах: Архангельской, Мурманской области, Кабардино-Балкарской Республике, Карачаево-Черкесской Республике, Республике Северная Осетия - Алания, Курганской области, Республике Тыва, Забайкальском крае, Республике Саха (Якутия) (ежегодные миграционные потери превышают 0,5 \% населения).

Данные официальной статистики - это только небольшая часть реального миграционного оборота. Личный опыт, а также публикации исследователей демографической ситуации в Республике Мордовия $[9, \mathbf{1 0}, \mathbf{1 1}, \mathbf{1 2}]$ показывают, что большая часть выехавших из республики на работу в другие регионы (чаще всего в города Москву и Санкт-Петербург, Московскую, Самарскую и Нижегородскую области) не меняют прописки, следовательно, в числе выбывших не учтены.

Особенно требовательны к условиям жизнедеятельности молодые люди. Кроме того, для этого возраста характерна высокая мобильность. Статистика подтверждает это. На возрастную категорию 15-29 лет приходится 36,9 \%, а по межрегиональному потоку - 37,3 \% всех прибывших. В исходящем потоке доля этой возрастной категории выше: в общей численности $-37,2$ \%, в межрегиональном обмене - 37,4 \% выбывших. Особенно страдают небольшие города. Удельный вес молодежи в общей численности выбывших составляет $37,6 \%$, а в межрегиональном обмене - 37,8 \% (2016 г.) [5].

В наши дни многие молодые люди уезжают учиться в вузы столиц и крупных городов. Среди плюсов таких перемещений следует отметить: получение молодыми людьми хорошего образования, расширение их кругозора, налаживание контактов и связей в других регионах, обмен социальной, культурной и исторической информацией и др. Однако такие поездки нередко завершаются сменой постоянного места жительства, что негативно сказывается как на демографическом, так и экономическом развитии территорий-доноров.

Политические и социально-экономические изменения последних десятилетий предоставили людям возможность покинуть родные места и переехать в другие города и за границу. Способствуют активизации миграционных потоков и такие фракторы, как отмена института "прописки", наличие относительно дешевых и быстрых способов перемещения, доступных средства коммуникации. 
Многих молодых людей решиться на переезд побуждает желание получить хорошо оплачиваемую работу. При этом они часто опираются на индормацию, полученную от знакомых, сделавших такой шаг ранее. Современные информационные технологии, которыми большинство молодых людей уверенно владеет, позволяют молодым людям получить необходимую информацию, а возможно и установить деловые контакты еще на стадии подготовки решения о переезде, что ускоряет его принятие. Поэтому в настоящее время поток молодых мигрантов из бедных регионов РФ с целью поиска достойной работы возрастает.

Среди молодых людей наибольшую подвижность проявляют студенты. Уезжая на учебу в другой город, многие совмещают учебу с временной работой, которая впоследствии часто трансформируется в постоянную занятость. Кроме того, сезонная миграция студентов в период студенческих каникул (студенческие отряды, программы обмена, летние школы, стажировки и т. п.) также предоставляет шансы для последующего трудоустройства.

Особую опасность представляет миграция молодежи для регионов с большой структурной долей населения старше пенсионного возраста. В трёх российских регионах (Рязанской, Тамбовской и Тульской областях) этот показатель превышает 30 \%, еще в 13 регионах приближается к этой отметке (табл. 4).

По мере увеличения среднего возраста жителей растет и средний возраст занятого населения. Перевод экономики на инновационный путь развития требует прилива молодых сил, обладающих самыми новыми знаниями, не обремененных штампами, способных мыслись и действовать быстро и креативно.

Таблица 4. Удельный вес населения старше пенсионного возраста в отдельных регионах Российской Федерации (оценка на конец года; в \% от общей численности населения)

\begin{tabular}{|l|l|l|l|l|l|l|l|l|l|}
\hline & $\mathbf{2 0 0 5}$ & $\mathbf{2 0 1 0}$ & $\mathbf{2 0 1 1}$ & $\mathbf{2 0 1 2}$ & $\mathbf{2 0 1 3}$ & $\mathbf{2 0 1 4}$ & $\mathbf{2 0 1 5}$ & $\mathbf{2 0 1 6}$ & $\mathbf{2 0 1 7}$ \\
\hline Российская Федерация & 20,5 & 22,3 & 22,6 & 23,1 & 23,5 & 24,0 & 24,6 & 25,0 & 25,4 \\
\hline Владимирская область & 24,3 & 25,9 & 26,4 & 26,9 & 27,4 & 27,9 & 28,5 & 28,9 & 29,4 \\
\hline Воронежская область & 25,1 & 26,2 & 26,5 & 26,9 & 27,3 & 27,7 & 28,1 & 28,5 & 28,9 \\
\hline Ивановская область & 24,8 & 26,1 & 26,5 & 26,8 & 27,2 & 27,6 & 28,1 & 28,5 & 28,9 \\
\hline Курская область & 24,3 & 25,6 & 26,0 & 26,4 & 26,9 & 27,4 & 27,8 & 28,2 & 28,8 \\
\hline Липецкая область & 23,5 & 24,9 & 25,4 & 25,9 & 26,3 & 26,9 & 27,5 & 27,9 & 28,5 \\
\hline Орловская область & 24,0 & 25,6 & 26,1 & 26,6 & 27,1 & 27,7 & 28,3 & 28,7 & 29,3 \\
\hline Рязанская область & 25,8 & 27,2 & 27,6 & 28,1 & 28,5 & 29,0 & 29,5 & 29,9 & 30,3 \\
\hline Тамбовская область & 25,0 & 26,7 & 27,2 & 27,7 & 28,1 & 28,6 & 29,3 & 29,9 & 30,5 \\
\hline Тверская область & 25,4 & 26,5 & 26,9 & 27,3 & 27,7 & 28,2 & 28,7 & 29,0 & 29,5 \\
\hline Тульская область & 26,3 & 27,8 & 28,1 & 28,6 & 29,1 & 29,5 & 29,9 & 30,2 & 30,6 \\
\hline Новгородская область & 24,3 & 26,0 & 26,5 & 27,1 & 27,7 & 28,2 & 28,7 & 29,1 & 29,7 \\
\hline Псковская область & 24,8 & 26,5 & 27,0 & 27,5 & 28,0 & 28,5 & 29,0 & 29,3 & 29,8 \\
\hline Кировская область & 22,0 & 24,5 & 25,1 & 25,8 & 26,5 & 27,3 & 28,0 & 28,6 & 29,2 \\
\hline Пензенская область & 23,7 & 25,8 & 26,3 & 26,8 & 27,4 & 27,9 & 28,5 & 29,1 & 29,6 \\
\hline Ульяновская область & 21,7 & 24,2 & 24,8 & 25,5 & 26,1 & 26,8 & 27,5 & 28,2 & 28,9 \\
\hline Курганская область & 21,9 & 24,6 & 25,3 & 26,1 & 26,7 & 27,3 & 27,9 & 28,5 & 29,1 \\
\hline
\end{tabular}

Источник: составлено на основе [16, с. 51-52]. 
Для закрепления молодежи в регионах необходимо развитие молодежных политических программ и общественных объединений, цель которых - создание условий для самореализации молодежи, применения творческого потенщиала молодых людей в интересах развития региона. Во многих регионах большая часть безработных - молодые люди. Особенно сложно трудоустроиться выпускникам учебных заведений, поскольку работодатели требуют наличие опыта профессиональной деятельности. Один из способов решения этой проблемы - включение в трудовой стаж периодов производственной практики. Это требует принятия соответствующих законодательных актов.

Облегчить последующее трудоустройство могло бы и адресное распределение выпускников на преддипломную практику. Не секрет, что сегодня этот ответственный этап обучения во многом проходит формально. На самом деле этот период мог бы стать хорошей основой для формирования у молодого человека чувства ответственности, сопричастности к общему делу, выработки трудовых навыков, способности взаимодействия в трудовом коллективе. А для потенциального работодателя такое сотрудничество позволило бы сделать правильный выбор и обеспечить обновление кадрового состава организации с минимальными рисками и без потерь, связанных с адаптацией работника на новом рабочем месте.

Другое наше предложение касается расширения возможности реализации молодыми людьми их предпринимательских способностей. Большинство выпускников вузов не регистрируются на бирже труда, поскольку не надеются на реальную помощь. Кроме того, многие амбициозные молодые люди считают, что "стоять на бирже" - удел неудачников. Из-за этого они лишены возможности участвовать в программах поддержки занятости, реализуемых государственной службой занятости. В этой связи предлагаем создать в регионах (например, при одном из вузов) молодежную биржу труда и/или допустить возможность участия в этих программах неработающих выпускников учебных заведений, не имеющих официального статуса безработного.

\section{Заключение}

Территориальная мобильность россиян в последние годы значительно усилилась. Это касается как международной, так и межрегиональной миграции. Опыт европейских стран показывает, что миграция может нанести урон экономике страны, поставить под угрозу социальную стабильность и вызвать изменения политического характера, что может серьезно затруднить продвижение государства по пути устойчивого социально-экономического развития. Не допустить этого позволит своевременная корректировка социально-экономической политики с учетом масштабов миграции, возрастного и национального состава мигрантов.

\section{Литература}

1. Вахаев Х. М. Трудовая миграция и национальная безопасность России // Право и безопасностью. 2011. № 3/4. С. 76-86.

2. Волох В. А. Концепция государственной миграционной политики России - основа миграционной безопасности страны / В. А. Волох, В. А. Суворова // NB: Национальная безопасность. 2013. № 3. С. 1-16.

3. Гаврилова Т. М. Влияние миграционных процессов на экономическую безопасность России / Т. М. Гаврилова // Национальные интересы: приоритеты и безопасность. 2011. № 27. С. 67-74.

4. Дементьев Н. В. Внешняя трудовая миграция как индикатор экономической безопасности России / Н. В. Дементьев // Социально-экономические явления и процессы. 2011. № 7. С. 38-41.

5. Демографический ежегодник России. 2017: Стат. сб. / Росстат. М., 2017.

6. Карпова И. В. Трудовая миграция и развитие бизнес-процессов в России // Лизинг. 2013. № 4. С. 30-41.

7. Карпова И. В. Трудовая миграция и национальный бизнес // Лизинг. 2011. № 3. C. 34-44.

8. "Лекарства от утечки умов нет и не будет". Из России бегут профрессионалы. Они не хотят прозябать на родине // Lenta.ru [Электронный ресурc]. URL: https://lenta. ru/articles/2018/06/18/poravalit/ (дата обращения 10.10.2019). 
9. Липатова Л. Н., Градусова В. Н. Основные тенденции и проблемы развития человеческого потенциала России в постсоветский период // Управленческое консультирование. 2019. № 6. С. 102-114.

10. Липатова Л. Н., Лещев Д. М., Градусова В. Н. Влияние миграции на формирование трудового потенщиала населения // Вестник НИИ гуманитарных наук при Правительстве PM. 2014. № 1. С. 106-119.

11. Липатова Л. Н., Мокрова М. Ю. Развитие человеческого потенциала России: основные тенденции и потенциал роста // Государство и бизнес. Экосистема цифровой экономики: Материалы XI Международной научно-практической конференции. СПб, 2019. C. 94-98.

12. Липатова Л. Н., Мокрова М. Ю. Современные тенденции развития человеческого потенциала России // Россия: Тенденции и перспективы развития. Ежегодник. Вып. 14 / РАН. ИНИОН. М., 2019. Ч. 1. С. 317-322.

13. Парикова Н. Миграционная привлекательность российских регионов / Н. Парикова // Человек и труд. 2012. № 5. С. 51-54.

14. Пруель Н. А., Градусова В. Н., Липатова Л. Н. Статистический анализ развития человеческого потенциала современной России // Статистика в условиях формирования цифровой экономики: материалы Международной научно-практической конференции. Саранск. 2019. С. 131-139.

15. Регионы России. Социально-экономические показатели: Стат. сб. / Росстат. M., 2018.

16. Российский статистический ежегодник: Стат. сб. / Росстат. М., 2018.

17. Рыбаковский Л. Л. Миграционная политика в контексте национальных интересов России / Л. Л. Рыбаковский // Уровень жизни населения регионов России. 2011. № 12 . C. $35-43$.

18. Рыбаковский О. Л. Межрегиональная миграция населения // Социологические исследования. 2011. № 4. С. 34-44.

19. Рязанцев С. России нужна новая миграционная политика / С. Рязанцев // Международные процессы. 2012. Т. 10. № 1. С. 111-116.

20. Утечка мозгов из России ускорилась // Lenta.ru https://lenta.ru/news/2018/01/23/ brain_drain/ (дата обращения 15.10.2019).

21. Фешина С. С. Трудовая миграция и проблема инновационного развития северо-западного региона России / С. С. Фешина, А. С. Славянов // Национальные интересы: приоритеты и безопасность. 2013. № 24. С. 38-43.

22. Хавинсон М. Ю. Прогнозирование динамики внешней трудовой миграции на региональном уровне / М. Ю. Хавинсон, М. П. Кулаков, С. Н. Мищук // Проблемы прогнозирования. 2013. № 2. С. 99-111.

23. Цырюльников В. С. Маятниковая миграция в контексте управления движением трудовых ресурсов: проблемы и перспективы (по материалам Московского региона) / В. С. Цырюльников // Управление персоналом и интеллектуальными ресурсами в России. 2013. Т. 2. № 1. С. 52-53.

24. Эмиграция из России - куда и почему уезжают граждане РФ? [Электронный pecypc]. URL: http://passus.ru/migratsiya/emigratsiya-iz-rossii-statistika-po-godam.html (дата обращения 15.10.2019).

25. Юрасов И. А. Структура трудовой миграции в регионах России / И. А. Юрасов, О. А. Лузгина, В. Д. Дорофеев // Известия высших учебных заведений. Поволжский регион. Общественные науки. 2012. № 4. С. 74-79.

26. Castles S., Miller M. The age of migration: international population movements in the modern world. London: Macmillan. 1993. 306 p.

27. Deleva Z. Conceptualizing Migration in Europe: Selected Theoretical Approaches // Institute of European Studies and International Relations Faculty of Social and Economic Sciences Comenius University Working Paper. 2010. № 4. P. 3-40.

28. Harris J., Todaro M. Migration, Unemployment, and Development: A Two-Sector Analysis // The American Economic Review. 1970. № 60. P. 126-142.

29. Lee E. A Theory of Migration // Demography. 1966. № 3. P. 47-57.

30. Massey D. A Synthetic theory of international migration // World in the mirror of international migration. 2002. № 10. P. 143-153.

31. Migration Theory. Talking across Disciplines / Edited by Caroline B. Brettell and James F. Hollield. New York: Routledge. 2000. 224 p.

32. Oishi N. Gender and Migration: An Integrative Approach // The Center for Comparative Immigration Studies CCIS University of California working paper. 2002. № 49. P. 1-18.

33. Sassen S. Regulating Immigration in a Global Age: A New Policy Landscape // Annals of the American Academy of Political and Social Science. 2000. № 570. P. 65-77.

34. Sassen S. The Mobility of Labor and Capital: A Study in International Investment and Labor Flow. New York: Cambridge University Press. 1988. 224 p.

35. Zelinsky W. The Hypothesis of the Mobility Transition // Geographical Review. 1971. № 61. P. 219-249. 


\section{Транслитерация по ГОСТ 7.79-2000 Система Б}

1. Vakhaev Kh. M. Trudovaya migratsiya i natsional'naya bezopasnost' Rossii // Pravo i bezopasnost'yu. 2011. № 3/4. S. 76-86.

2. Volokh V. A. Kontseptsiya gosudarstvennoj migratsionnoj politiki Rossii - osnova migratsionnoj bezopasnosti strany / V. A. Volokh, V. A. Suvorova // NB: Natsional'naya bezopasnost'. 2013. № 3. S. 1-16.

3. Gavrilova T. M. Vliyanie migratsionnykh protsessov na ehkonomicheskuyu bezopasnost' Rossii / T. M. Gavrilova // Natsional'nye interesy: prioritety i bezopasnost'. 2011. № 27. S. $67-74$.

4. Dement'ev N. V. Vneshnyaya trudovaya migratsiya kak indikator ehkonomicheskoj bezopasnosti Rossii / N. V. Dement'ev // Sotsial'no-ehkonomicheskie yavleniya i protsessy. 2011. № 7. S. 38-41.

5. Demograficheskij ezhegodnik Rossii. 2017: Stat. sb. / Rosstat. M., 2017.

6. Karpova I. V. Trudovaya migratsiya i razvitie biznes-protsessov v Rossii // Lizing. 2013. № 4. S. 30-41.

7. Karpova I. V. Trudovaya migratsiya i natsional'nyj biznes // Lizing. 2011. № 3. S. 34-44.

8. "Lekarstva ot utechki umov net i ne budet". Iz Rossii begut professionaly. Oni ne khotyat prozyabat' na rodine // Lenta.ru [Ehlektronnyj resurs]. URL: https://lenta.ru/articles/2018/06/18/poravalit/ (data obrashheniya 10.10.2019).

9. Lipatova L. N., Gradusova V. N. Osnovnye tendentsii i problemy razvitiya chelovecheskogo potentsiala Rossii v postsovetskij period // Upravlencheskoe konsul'tirovanie. 2019 . № 6. S. 102-114.

10. Lipatova L. N., Leshhev D. M., Gradusova V. N. Vliyanie migratsii na formirovanie trudovogo potentsiala naseleniya // Vestnik NII gumanitarnykh nauk pri Pravitel'stve RM. 2014. № 1. S. 106-119.

11. Lipatova L. N., Mokrova M. Yu. Razvitie chelovecheskogo potentsiala Rossii: osnovnye tendentsii i potentsial rosta // Gosudarstvo i biznes. EHkosistema tsifrovoj ehkonomiki: Materialy XI Mezhdunarodnoj nauchno-prakticheskoj konferentsii. SPb, 2019. S. 94-98.

12. Lipatova L. N., Mokrova M. Yu. Sovremennye tendentsii razvitiya chelovecheskogo potentsiala Rossii // Rossiya: Tendentsii i perspektivy razvitiya. Ezhegodnik. Vyp. 14 / RAN. INION. M., 2019. CH. 1. S. 317-322.

13. Parikova N. Migratsionnaya privlekatel'nost' rossijskikh regionov / N. Parikova // CHelovek i trud. 2012. № 5. S. 51-54.

14. Pruel' N. A., Gradusova V. N., Lipatova L. N. Statisticheskij analiz razvitiya chelovecheskogo potentsiala sovremennoj Rossii // Statistika v usloviyakh formirovaniya tsifrovoj ehkonomiki: materialy Mezhdunarodnoj nauchno-prakticheskoj konferentsii. Saransk. 2019. S. 131-139. 2018 .

15. Regiony Rossii. Sotsial'no-ehkonomicheskie pokazateli: Stat. sb. / Rosstat. M.,

16. Rossijskij statisticheskij ezhegodnik: Stat. sb. / Rosstat. M., 2018.

17. Rybakovskij L. L. Migratsionnaya politika v kontekste natsional'nykh interesov Rossii / L. L. Rybakovskij // Uroven' zhizni naseleniya regionov Rossii. 2011. № 12. S. 3543.

18. Rybakovskij O. L. Mezhregional'naya migratsiya naseleniya // Sotsiologicheskie issledovaniya. 2011. № 4. S. 34-44.

19. Ryazantsev S. Rossii nuzhna novaya migratsionnaya politika / S. Ryazantsev // Mezhdunarodnye protsessy. 2012. T. 10. № 1. S. 111-116.

20. Utechka mozgov iz Rossii uskorilas' // Lenta.ru https://enta.ru/news/2018/01/23/ brain_drain/ (data obrashheniya 15.10.2019).

$2 \overline{1}$. Feshina S. S. Trudovaya migratsiya i problema innovatsionnogo razvitiya severo-zapadnogo regiona Rossii / S. S. Feshina, A. S. Slavyanov // Natsional'nye interesy: prioritety i bezopasnost'. 2013. № 24. S. 38-43.

22. KHavinson M. Yu. Prognozirovanie dinamiki vneshnej trudovoj migratsii na regional'nom urovne / M. Yu. KHavinson, M. P. Kulakov, S. N. Mishhuk // Problemy prognozirovaniya. 2013. № 2. S. 99-111.

23. TSyryul'nikov V. S. Mayatnikovaya migratsiya v kontekste upravleniya dvizheniem trudovykh resursov: problemy i perspektivy (po materialam Moskovskogo regiona) / V. S. TSyryul'nikov // Upravlenie personalom i intellektual'nymi resursami v Rossii. 2013. T. 2. № 1. S. 52-53.

24. EHmigratsiya iz Rossii - kuda i pochemu uezzhayut grazhdane RF? [Ehlektronnyj resurs]. URL: http://passus.ru/migratsiya/emigratsiya-iz-rossii-statistika-po-godam. html (data obrashheniya 15.10.2019).

25. YUrasov I. A. Struktura trudovoj migratsii v regionakh Rossii / I. A. YUrasov, O. A. Luzgina, V. D. Dorofeev // Izvestiya vysshikh uchebnykh zavedenij. Povolzhskij region. Obshhestvennye nauki. 2012. № 4. S. 74-79. 
26. Castles S., Miller M. The age of migration: international population movements in the modern world. London: Macmillan. 1993. 306 p.

27. Deleva Z. Conceptualizing Migration in Europe: Selected Theoretical Approaches // Institute of European Studies and International Relations Faculty of Social and Economic Sciences Comenius University Working Paper. 2010. № 4. P. 3-40.

28. Harris J., Todaro M. Migration, Unemployment, and Development: A Two-Sector Analysis // The American Economic Review. 1970. № 60. P. 126-142.

29. Lee E. A Theory of Migration // Demography. 1966. № 3. P. 47-57.

30. Massey D. A Synthetic theory of international migration // World in the mirror of international migration. 2002. № 10. P. 143-153.

31. Migration Theory. Talking across Disciplines / Edited by Caroline B. Brettell and James F. Hollield. New York: Routledge. 2000. 224 p.

32. Oishi N. Gender and Migration: An Integrative Approach // The Center for Comparative Immigration Studies CCIS University of California working paper. 2002. № 49. P. 1-18.

33. Sassen S. Regulating Immigration in a Global Age: A New Policy Landscape // Annals of the American Academy of Political and Social Science. 2000. № 570. P. 65-77.

34. Sassen S. The Mobility of Labor and Capital: A Study in International Investment and Labor Flow. New York: Cambridge University Press. 1988. 224 p.

35. Zelinsky W. The Hypothesis of the Mobility Transition // Geographical Review. 1971. № 61. P. 219-249.

\begin{abstract}
Липатова Л. Н. Исследование миграционных процессов в современной России с позиции обеспечения әкономической безопасности.

В статье на основе данных официальной статистики и экспертных оценок проведен анализ ситуации в сфере миграции населения в России, выявлены основные направления перераспределения населения, обоснована необходимость корректировки социально-экономической политики в регионах, испытывающих значительный миграционный оборот. Сделаны выводы о возможном усилении негативного влияния миграционных процессов на социально-экономическое развитие Российской Федерации в целом и отдельных регионов в частности, что требует их детального изучения в целях принятия мер по оптимизации миграционных потоков и корректировке социально-экономической политики.
\end{abstract}

Ключевые слова: население, миграиия, эконолическая безопасность, социальная стабильность, трудовой потенциал, рынок труда, государственная социально-эконолическая политика

Lipatova L. N. The study of migration processes in modern Russia from a position of ensuring economic security.

On the basis of official statistics and expert estimates, an analysis of the situation in the field of population migration in Russia was carried out, the main directions of population redistribution were identified, the need for adjusting the socio-economic policy in regions experiencing significant migration was substantiated. Conclusions are drawn about the possible increase in the negative impact of migration processes on the socio-economic development of the Russian Federation as a whole and individual regions, in particular, which requires their detailed study in order to take measures to optimize migration flows and adjust social and economic policies.

Key words: population, migration, economic security, social stability, labor potential, labor market, state socio-economic policy

Для цитирования: Липатова Л. Н. Исследование миграционных процессов в современной России с позиции обеспечения экономической безопасности // Ойкумена. Регионоведческие исследования. 2020. № 1. С. 53-65. DOI: 10.24866/1998-6785/2020-1/53-65

For citation: Lipatova L. N. The study of migration processes in modern Russia from a position of ensuring economic security // Ojkumena. Regional researches. 2020. № 1. P. 53-65. DOI: $10.24866 / 1998-6785 / 2020-1 / 53-65$ 


\section{Интеграция и социальная адаптация мигрантов: основы государственной политики и опыт Республики Мордовия}

\section{Постановка проблемы}

На протяжении XX в. в мире наблюдалось интенсивное расширение миграционных потоков, которые к концу века актуализировали глобальные проблемы, требуя иных подходов к миграционной политике для достижения и поддержания баланса интересов сторон, участвующих в регулировании миграционных процессов. Миграция населения, с одной стороны,-проблема современного мирового развития, с другой - политический и социально-экономический феномен социального преобразования регионов, влияющий на состав трудовых ресурсов стран-доноров и стран-реципиентов, привнося изменения в социальную и политическую жизнь последних. Всплеск миграции детерминируют мировые войны, распад многонациональных государств и создание новых. В условиях свободного перемещения людей экономическая миграция определяет предложение рабочей силы, циклическая миграция влияет на занятость и уровень заработной платы (превышает 1 \% населения во многих странах Европы [25]), разрыв в производительности труда [24], преобразует структуру внутренней трудовой миграции [23].

В России начало XXI столетия характеризовалось ростом миграции населения, начавшейся в конце предыдущего столетия в связи с разрушением СССР. Вопросы адаптаиии и интеграиии иностранных граждан и лии без гражданства в миграционной сфрере реактуализировались в последнее время по причине недостаточной урегулированности правового положения, изоляции и увеличения отрицательного отношения к таким лицам в стране-реципиенте $[8 ; 17 ; 18$, с. 6]. В число основных форм интеграции иностранных граждан в новое сообщество вошли экономическая, экологическая, гражданская, социально-психологическая, культурная и религиозная [16, с. 35].

В Концепции государственной миграционной политики Российской Федерации на период до 2025 г. [20] определены её основные направления в части содействия социализаџии мигрантов, формирования конструктивного диалога между ними и принимающей стороной, противодействия их социальной исключённости, пространственной сегрегации и создания этнических анклавов.

Феномен социальной исключённости получил широкое распространение в настоящее время из-за потребности описания в иной системе ценностей отношений в оппозициях: "Свой - Другой - Чужой - Опасный". Обособление и замкнутость в узких границах себе подобных в современном смысловом контексте несет негативно оценочный смысл самого явления как такового.

\section{(С) Бахлов И. В., Кильдюшкина И. Г., Липатова Л. Н., 2020}

БАХЛОВ Игорь Владимирович, д-р полит. наук, доцент, заведующий кафедрой всеобщей истории, политологии и регионоведения Национального исследовательского Мордовского государственного университета им. Н. П. Огарёва (е. Саранск). E-mail: bahlov@mail.ru

КИЛЬДЮШкИНА Ирина Геннадьевна, канд. ист. наук, доцент, главный научный сотрудник - заведующая отделом региональных исследований и программ Научно-исследовательского института гуманитарных наук при Правительстве Республики Мордовия (е. Саранск). E-mail: irakil1967@mail.ru

ЛИПАТОВА Людмила Николаевна, д-р социол. наук, канд. экон. наук, доцент, профессор кафедры экономики Северо-Западного института управления РАНХиГС (г. Санкт-Петербург). E-mail: ln.lipatova@yandex.ru 
Согласно точке зрения И. В. Ивахнюк [6], существуют два сценария развития России. В соответствии с первым, государство должно формироваться на русско-православном культурном ядре. Сторонники этого течения, обеспокоенные социо-этно-конфессиональными эффректами миграций, придерживаются изоляционизма и жесткости в отношении вопросов ограничения притока иммигрантов. Альтернативная позиция: исходя из долгосрочных демографических, экономических и политических интересов, России без иммигрантов не обойтись.

Особо значимым в этом дискурсе фрактором выступает усиление демографической нагрузки на работающих. По низкому и среднему вариантам демографрического прогноза Росстата, опубликованному до законодательного повышения верхней границы трудоспособного возраста в РФ, при сокращении к 2050 г. численности населения страны на 12,3-3,5 \% (численность россиян на 1 января 2018 г. составляла 146880 тыс. чел.) численность населения в трудоспособном возрасте уменьшится на 23,0-14,4 \% (численность населения в трудоспособном возрасте на 1 января 2018 г. -82264 тыс. чел.). Даже по самому благоприятному сценарию, предполагающему рост численности населения РФ к 2050 г. на 11,2 \%, его численность в возрасте 16-55 лет (женщины) и 16-60 лет (мужчины) уменьшится более чем на 7 \% [15, с. 91].

Ожидаемое ускорение темпов экономического роста в РФ и ограничения развития экономической системы страны со стороны народонаселения (даже при поэтапном повышении верхней границы трудоспособного возраста) делает необходимым привлечение рабочей силы с внешних рынков труда.

В ряде субъектов РФ, в частности в Республике Мордовия, в которой процесс старения населения протекает более быстрыми темпами, рассматриваемые вопросы в контексте обеспечения устойчивого развития әкономической системы стоят острее. Можно сказать, что сложившийся демографический фрон создает реальную угрозу экономической безопасности региона. Один из 40 индикаторов экономической безопасности, сформированных в п. 27 Стратегии экономической безопасности Российской Федерации на период до 2030 г., - доля населения трудоспособного возраста в общей численности населения. Пока удельный вес населения в трудоспособном возрасте в Республике Мордовия более высокий, чем в среднем в стране, в 2012-2017 гг. - самый высокий в Приволжском федеральном округе (ПФО) [14, с. 49-50]. Однако с учётом того, что удельный вес населения моложе трудоспособного возраста в регионе существенно ниже, чем в среднем в РФ, ситуация изменится уже в ближайшие годы. С 2012 г. доля детей и подростков в Мордовии - самая низкая среди регионов ПФО [14, с. 47-48].

Исследования показывают, что население достаточно скептично относится к перспективам интеграции мигрантов [9], которые игнорируют общепринятые образцы и традиции принимающего сообщества, а их интеграционные настроения и ожидания зачастую контрастируют с настроениями стороны-реципиента, что дестабилизирует общество.

Представляется, что вопросы интеграции и защиты прав мигрантов должны решаться в двустороннем порядке [4], принимая во внимание как процессы языковой, культурной и экономической социализации, дифрференциацию по репатриантам-соотечественникам, иммигрантам и трудовым мигрантам, так и долгосрочные вызовы второго поколения иностранцев, прибывших в РФ [22]. Иммиграция и внешняя трудовая миграция решают стратегические задачи национального характера и геополитики, в основном для поддержания потенциала демографического и экономического развития. Согласно "низкому варианту" прогноза Росстата, в обозримом будущем миграционный прирост не опустится ниже 100 тыс. чел. в год; по "среднему" - предполагается постепенное повышение сальдо миграции с 262 тыс. (2016 г.) до 293 тыс. чел., достигнутых к 2030 г.; при "высоком" можно ожидать увеличения миграционного прироста до 456 тыс. чел. в 2030 г. [3, 8.1]. Тем самым фокус миграционных проблем смещается на периферию социализации иммигрантов. Если иноэтничные мигранты не станут лояльными гражданами независимо от их этногенеза и государства выхода, то их массовый приток в скором будущем может вызвать глобальные последствия для национальной безопасности РФ. 
De fakto, в целом по России миграция трудовых ресурсов извне объективно экономически обусловлена. В частности, за последние 20 лет миграционный прирост в РФ в значительной степени компенсировал более половины естественной убыли населения. По расчету Федеральной службы государственной статистики о перспективной численности населения до 2030 г. (высокий и средний варианты), учитывающему результаты Всероссийской переписи населения 2010 г. и динамику демографических процессов последних лет, численность населения России на начало 2025 г. достигнет 146 548,1150601,7 тыс. чел. [3, 8.1].

В связи с этим в переселении иностранных граждан и лиц без гражданства мыслится один из фракторов увеличения численности населения РФ. Вовлечение иностранной рабочей силы в приоритетные профессионально-квалификационные группы становится важным компонентом её дальнейшего устойчивого развития [26]. Более того, работники-мигранты высокой квалификации - источник накопления человеческого капитала в принимающих странах. Конкуренция за наличие в социальной и экономической сфере требуемых специалистов разного профиля, а также предпринимателей и инвесторов на долгосрочной основе сегодня расширяется и геополитизируется.

Подобное положение требует неотложных мер по созданию эффективной, универсальной модели социальной адаптации и интеграции мигрантов в российское общество вследствие неподготовленности современных государственных институтов к их социализации. Цель нашего исследования - поиск альтернатив миграционной политики, социокультурных ограничений интеграции и социальной исключённости мигрантов, которые в последнее время приобретают фундаментальный и конъюнктурный характер.

В качестве объекта исследования выбрана государственная миграционная политика Российской Федерации. Материальной базой для проведения системного аналитическо-синтетического изучения научно-теоретических, прикладных и программно-концептуальных информационных ресурсов, политологического и экономико-статистического анализа в этой области послужили открытые данные фоедеральной и региональной статистики по обозначенной проблематике, фредеральные и региональные нормативно-правовые акты, программно-целевые документы стратегического характера, регулирующие аспекты социальной адаптации и интеграции мигрантов в российское общество. Некоторые выводы сформулированы на основе контент-анализа, одновременно содержащего в себе случайную выборку, точное измерение и операциональные дефиниции абстрактных конструктов за рассматриваемый период. Использование методов аналитической и динамической интерпретации научной и статистической информации, а также экспертных оценок позволило формализовать процедуры сбора, обобщения и анализа мнений специалистов с императивом преобразования их в форму, приемлемую для определения ориентиров и механизмов федерального, регионального и местного уровней управления в части подготовки современных государственных институтов России к социализации иностранных граждан и лиц без гражданства. Метод моделирования применялся при по построении универсальной модели социальной адаптации и интеграции мигрантов в российское общество и разработке практических мер по регулированию миграционных процессов в России.

\section{Инструменты реализации государственной национальной политики в Республике Мордовия}

В настоящее время органами власти региона ведется систематическая работа по совершенствованию государственной политики и нормативно-правового регулирования в сфере миграции [1]. Ее основы заложены в Стратегии государственной национальной политики Российской Федерации на период до 2025 г. [7] и ряде других актов. На системной основе проводится комплекс организационных и профилактических мероприятий по адаптации и интеграции мигрантов, недопущению возникновения очагов социальной напряженности, вызванных негативными процессами на межнациональной почве. Серьезный позитивный опыт работы с трудовыми мигрантами накоплен во многих регионах РФ. 
Осознание возможных рисков и угроз, готовность властных структур $\mathrm{Pe}$ спублики Мордовия своевременно корректировать внутреннюю национальную политику, не дожидаясь усиления антимигрантских выступлений, решается на основе обобщения лучших региональных практик в данной сфрере.

Важным инструментом реализации государственной национальной политики в Республике Мордовия в контексте развития общероссийских процессов является социальная и культурная адаптация, интеграция инокультурных мигрантов, которая объективируется в тандеме с неправительственными общественными организациями, землячествами, представляющими интересы этнических и религиозных групп. В регионе выработаны методические рекомендации для подведомственных силовых структур о порядке выявления формирующихся конфликтов в сфере межнациональных отношений, их предупреждения и купирования [12]. Меры по поддержке иностранных граждан, проживающих в Республике Мордовия, заложены в действующей государственной программе "Гармонизация межнациональных и межконфессиональных отношений в Республике Мордовия" [13]. На регулярной основе ведётся подготовка и переподготовка государственных гражданских и муниципальных служащих, ответственных за данный круг проблем.

Реализация ключевых направлений государственной миграционной политики в данной сфрере и защиты коренного населения осуществляется добровольными некоммерческими объединениями, автономными НКО, общественными объединениями (фондами), центрами социальной адаптации трудовых мигрантов, НКА, диаспорами, Русской православной церковью и управленческими структурами.

Следует иметь в виду, что мигращия населения в последние десятилетия стала одним из наиболее весомых фракторов социально-экономического и политического развития региона. Она аккумулирует целый спектр болезненных вопросов, включая столкновение культур, общеуголовную и этническую преступность, религиозный экстремизм и терроризм.

Из социальных проблем выделяются, во-первых, потенциальная возможность роста ксенофобских настроений среди жителей страны и связанное с этим увеличение числа жертв ксенофобского насилия среди мигрантов, что вызывает мигрантофобию среди местного населения. Во-вторых, порождение широко распространенного убеждения угрозы социальной стабильности, исходящей от мигрантов, провоцирует размывание культурного ядра локального сообщества, привнося чуждые традиции и нормы поведения. В-третьих, мигранты нового поколения выделяются более низким уровнем образования и квалификации, в том числе плохим знанием русского языка, создавая проблемы, прежде всего, для самих себя [19].

Недостаточная результативность контрольных фонкций государства ведёт к росту числа неквалифицированных иностранных рабочих, нарушению миграционного и трудового законодательства со стороны недобросовестных работодателей в целях экономии денежных средств, игнорированию интересов работников и фрормированию значительного контингента безработных "гастарбайтеров", лишённых средств к существованию и являющихся носителями иной религиозной традиции.

В то же время усилился контроль за соблюдением мигрантами миграционного законодательства. В 2013 г. создана Государственная информационная система миграционного учета (ГИСМУ), обеспечившая персонифицированный учёт иностранных граждан, находящихся в России. С 2015 г. создаётся сеть многофункциональных миграционных центров для оказания разного рода миграционных услуг иностранным гражданам. Регионы тем самым получают право самостоятельно регулировать приток иностранных граждан, в том числе иностранных работников.

Мигранты часто становятся объектом для вербовки в экстремистские и террористические объединения и нередко распространяют экстремистскую идеологию, создавая ячейки запрещенных в России организаций. Более того, они в определённой степени осложняют криминогенную ситуацию, усиливают социальную напряжённость и ксенофобию, способствуют возникновению этноконфессиональных противоречий, этнических анклавов, организованных преступных групп и террористических ячеек. Риторика в СМИ вокруг темы "кризиса и санкций" углубляла явную и мнимую конкуренцию на рынке тру- 
да, провоцируя конфликты между представителями разных культурных сообществ.

Чтобы понять причины случившегося, необходимо заглянуть в недалекое прошлое, когда общероссийские кризисные явления 1990-х гг., затронувшие и Мордовию, проявились затяжным экономическим спадом и общим ухудшением уровня жизни, и, как следствие, ростом преступности, сокращением рождаемости и оттоком населения. В результате активизировалось столкновение различных политических сил, особенно в начале десятилетия.

Наметившийся экономический подъем начала 2000-х гг. привел к ослаблению оппозиции республиканской власти, улучшению демографической ситуации, переоценке роли и влияния этнического и религиозного фракторов в региональной политике. Впоследствии происходила трансформация сформировавшихся ранее национально-культурных и политических движений мордовского (мокша и эрзя) и татарского народов. Мейнстрим политизированных требований первой половины 1990-х гг., большей частью сопровождавшихся критикой республиканских органов власти (без выдвижения сепаратистских лозунгов), сменился сотрудничеством с руководством региона при условии их поддержки. Важную роль в этом движении сыграли Национально-культурные автономии (НКА), однако полное подчинение этнополитических и этнокультурных движений Мордовии властям породило фрустрации их деятельности в фрорме более решительного выражения симпатий некоторых этносов.

Процессы религиозного возрождения, характерные для конца 1980-х - начала 2000-х гг., усилили влияние Русской православной церкви, получившей в регионе покровительство со стороны политической и экономической элиты, а также мусульманского сообщества (уммы), организованного татарами республики. Кроме того, оживилась деятельность многочисленных протестантских организаций. В республике достигнута значительная стабильность межконорессиональных отношений.

По данным Всероссийской переписи населения 2010 г., в Республике Мордовия проживают представители 119 нащиональностей [13]. Руководством региона созданы все условия не только для беспрепятственной миграции населения, но и для совместного проживания представителей различных национальностей. Огромная постоянная работа ведется по гармонизации взаимодействия между представителями различных нащиональностей и конорессий, вовлечению их в общественную жизнь республики на принщипах дружелюбия, справедливости, интернационализма и др.

Региональные СМИ и интернет-ресурсы как канал политической коммуникации, безусловно, влияют на этнополитическую ситуацию в республике, не меняя общего вектора информационных процессов. При отсутствии серьезных проблем между этническими и этноконфессиональными группами Республики Мордовия есть потенциальные риски этноконфессионального свойства - возможность радикализации отдельных конфессиональных групп и сообществ (салафиты, часть мусульманской уммы, национальная организация "Фонд спасения эрзянского языка"), а, следовательно, и возможность изменения характера их взаимодействия.

Отмечаются также изменения в национальном составе населения, что осложняет ситуацию в сфере общественных отношений: естественное движение населения и миграционные процессы, в результате которых в регионе сформировались относительно немногочисленные (по несколько сотен человек) группы выходцев из республик Северного Кавказа и бывших союзных республик (узбеки, таджики, казахи, грузины, туркмены и т. д.). По данным статистики, ежегодно в регион прибывает 3,2-5,6 тыс. чел. [13]. Старение населения, обусловливающее угрозу дефицита рабочих рук, усугубит нагрузку и на трудоспособных жителей, и на системы социальной поддержки населения и здравоохранения в плане выплат пенсий и социальных пособий.

Несмотря на увеличение количества прибывающих в регион иностранных граждан, миграционная обстановка на территории Мордовии остается стабильной. Конфрликтных ситуаций между представителями различных национальностей не возникало.

В соответствии с указом Президента РФ от 05.04.2016 № 156 Федеральная миграционная служба (ФМС) России была аннулирована, а её функции переданы Министерству внутренних дел России - Главному управлению по 
вопросам миграции, что означало передорматирование институционального обеспечения миграционной политики.

В полномочиях Управления по вопросам миграции МВД России по Республике Мордовия выделяются два основных вектора работы. Первый связан с оказанием государственных услуг россиянам. В этом направлении достигнуты неплохие показатели по срокам оформления документов, внутренних и заграничных паспортов. По второму - работе с иностранными гражданами, ведомство курирует выдачу разрешительных документов иностранным гражданам и контролирует их пребывание в регионе. В настоящее время данная структура предоставляет 17 видов государственных услуг в сфере миграции. Ежегодно предоставляется свыше 200 тысяч услуг, самые популярные из которых - регистрационный учет российских граждан и миграционный учет иностранных, пребывающих на территорию Мордовии с целью осуществления трудовой деятельности, ознакомления с туристическими объектами, обучения, лечения и др. [21].

На наш взгляд, создание балльной системы отбора мигрантов для получения ими вида на жительство, введение ускоренного (упрощенного) порядка получения ими российского гражданства, предусмотренное в рамках воплощения в жизнь Концепции государственной миграционной политики Российской Федерации на период до 2025 г., приемлемо и для Республики Мордовия.

Миграция иностранных граждан признается руководством региона одним из источников восполнения потерь численности населения Республики Мордовия. Поэтому стимулирование миграционного притока имеет большое значение для сбалансированности рынка труда и социально-экономического развития региона, но вместе с этим иностранные граждане создают потенциальную угрозу пространственной сегрегации и фрормированию этнических анклавов, не говоря о социально-экономической целесообразности их адаптации и интеграции в региональное сообщество.

Только в 2013-2017 гг. на территорию этого небольшого региона въехало 34,5 тыс. иностранных граждан. В 2015-2017 гг. поток мигрантов из-за рубежа сильно активизировался (ежегодно пребывало 8-11 тыс. иностранных граждан, что превысило 1 \% населения региона - 808,9 тыс. чел. на начало 2015 г.). Осложнит эпидемиологическую обстановку и функционирование социальной инфраструктуры республики стремление большей их части поселиться в столице Мордовии с численностью населения 331,7 тыс. чел (2015 г.). Новые требования к организации системы образования, здравоохранения и работе органов внутренних дел выдвигает миграционный прирост населения Республики Мордовия: в 2013-2017 гг. по международному направлению этот показатель составил 25,6 тыс. чел. (более 3 \% численности населения в начале 2013 г.) [рассчитано по: $\mathbf{1 0 , \text { c. } \mathbf { 5 2 } , \mathbf { 5 8 , 8 7 ] . }}$

Массовый приток трудовых мигрантов может дестабилизировать ситуацию на рынке труда. В 2017 г. в экономике региона официально было занято более 3,4 тыс. иностранных граждан, или в 1,6 раза больше, чем в Республике Марий Эл, Кировской области и Чувашской Республике вместе взятых $[\mathbf{1 4}$, c. 169]. Это около $1,5 \%$ численности занятых в экономике [рассчитано по: 11, c. 105,$211 ; 14$, c. 169 ], что весьма ощутимо для регионального рынка труда, так как численность зарегистрированных в государственных учреждениях службы занятости безработных только немного больше численности иностранных трудовых мигрантов - 4 тыс. чел. [11, с. 93].

В Стратегии социально-экономического развития Республики Мордовия на период до 2025 г. декларируется неизбежность роста спроса хозяйствующих субъектов в кадрах широкого профиля [5]. Бесспорно, реализация региональной программы по оказанию содействия добровольному переселению в РФ соотечественников, проживающих за рубежом, будет этому способствовать. Однако основная доля иностранных мигрантов республики - выходцы из Средней Азии, менталитет которых значительно отличается от коренных жителей. Появляется угроза возникновения этнических анклавов, обусловленных проникновением на территорию региона әкстремистских групп. На это указывает факт рекрутирования из небольшой республики нескольких десятков человек в ряды ИГИЛ (запрещенной в РФ организации). 
Несмотря на некоторые деструктивные тенденции (православно-протестантские противоречия; организационный раскол в умме; проникновение в республику салафитов и отдельных тоталитарных религиозных организаций), этноконфессиональная ситуация в регионе в целом остается стабильной.

С целью оказания практической помощи в конце 2015 г. НИИ гуманитарных наук при Правительстве Республики Мордовия в рамках госпрограммы "Гармонизация межнациональных и межконфессиональных отношений в Республике Мордовия" было подготовлено и издано первое в России учебно-методическое пособие для мигрантов "Все мы - Россия", которое было распространено, в том числе и по НКО, сфрормированным по национальному признаку [2]. Оно помогает иностранным гражданам готовиться к әкзаменам по русскому языку, основам законодательства и истории России. Кроме справочного материала в него включены тесты. Региональная составляющая обеспечена краткими сведениями о Республике Мордовия как субъекте РФ. Подобных работ нет ни в одном регионе страны.

Вместе с тем спонтанность, нетранспарентность и непоследовательность технократических мер в принципе игнорируют проблемы в этой области. Нормативный компонент рассматриваемой системы сегодня довольно обширен, хотя степень законодательной институционализации сореры государственной миграционной политики в целом видится недостаточной. Несоответствие полномочий и возможностей директивных органов их ключевой роли в субъектах РФ /муниципалитетах ограничивают акты по фрормированию единого механизма социализации иностранной рабочей силы в стране.

\section{Заключение}

Резюмируя изложенное выше, можно сделать вывод, что в сложившейся ситуации целесообразными представляются следующие действия фредерального, регионального и местного уровней управления:

- совершенствование системы регулирования миграции населения и порядка привлечения иностранных работников;

- формирование долгосрочной стратегии сбалансированного сочетания национальных и иностранных миграционных ресурсов при условии непременного уважения, соблюдения и действенной защиты прав, свобод и законных интересов всех сторон (граждан России и иностранных граждан) с целью выработки четкой линии государственной миграционной политики по привлечению, в частности, трудовых мигрантов;

- разработка и принятие в субъектах РФ стратегии привлечения трудовых мигрантов с учетом отраслевой специфики и потребностей локального рынка труда;

- совершенствование миграционного законодательства с учетом региональной специфики и формирования характерного комплекса формальных региональных практик;

- увеличение квот на выдачу иностранным гражданам разрешений на временное проживание для законопослушных трудовых мигрантов и предоставление им вида на жительство с учетом демографической ситуации в субъекте РФ и его возможностей по их обустройству для сокращения времяпровождения в территориальном органе федерального органа исполнительной власти в сфрере внутренних дел;

- ужесточение меры наказания иностранного гражданина или лица без гражданства за фриктивную регистрацию по месту жительства или фриктивную постановку на учет по месту пребывания в жилом помещении в РФ;

- увеличение суммы штрафа за незаконное вовлечение в трудовую деятельность в РФ иностранного гражданина или лица без гражданства;

- вовлечение в работу с инокультурными мигрантами (на постоянной основе) представителей традиционных конфессий (православие и ислам);

- отнесение к сфере деятельности частных агентств трудоустройства вопросов "нулевого уровня" адаптации мигрантов, подготовки первичных документов, обеспечения контактов между ними и НКО, оказывающими поддержку в РФ;

- вовлечение в решение проблем социализации трудовых мигрантов силами НКО с помощью их взаимодействия с муниципалитетами; 
- проведение подготовительных курсов для трудовых мигрантов совместно с сотрудниками национально ориентированных НКО, направленных на предоставление информации по правам и обязанностям, нормам и культуре поведения в принимающем сообществе, профилактику правонарушений, купирование проявлений экстремизма и терроризма, а также правил профрилактики социально значимых заболеваний;

- разработка, издание и распространение информационных материалов о субъекте РФ, его социально-экономическом развитии, культуре и традициях населяющих его народов на родных для мигрантов языках;

- развитие широкого спектра образовательных, культурных и языковых программ, специальных интернет-ресурсов по вопросам трудоустройства и их социокультурной адаптации, с императивом обеспечения наиболее эфрфективными формами социализации трудовых мигрантов;

- создание телефонов доверия, мобильного приложения, позволяющего проводить online-консультации для мигрантов по медицинским, юридическим и иным вопросам;

- внедрение системы мобильного социального патронажа в местах проживания, трудовой деятельности и досуга мигрантов;

- обеспечение предоставления юридической и медико-социальной поддержки мигрантам на базе Центров содействия мигрантам;

- мониторинг ситуации в среде мигрантов с целью нивелирования и минимизации негативных последствий миграции, оценки состояния и определения перспектив развития межнациональных и межконфессиональных отношений в каждом субъекте РФ и стране в целом;

- вовлечение глав диаспор и старейшин мигрантов в совместную работу с местным населением;

- проведение тренингов межкультурного взаимодействия с участием глав диаспор, старейшин, а также лиц, занимающих ответственные должности, учителей и других категорий населения;

- разработка конструктивных социально-психологических методик обучения межэтническому взаимодействию по типу применяемых в других странах "культурных ассимиляторов";

- постоянный контроль взаимодействия мигрантов с коренным населением;

- подготовка специалистов системы образования к работе с полиэтничными учащимися, нацеленной на предотвращение дискриминационных практик и конфрликтов;

- отказ в поликультурных регионах от дихотомии "титульные - нетитульные" и "коренные - некоренные" во избежание перерастания в межэтнические конфрликты за политическое и экономическое доминирование;

- обеспечение условий для социализации, включая доступ иностранных граждан и членов их семей к социальным, медицинским и образовательным услугам в зависимости от их правового статуса, обучение русскому языку, культурным традициям и обычаям; рубежом.

- содействие распространению русского языка и русской культуры за

Рекомендации и предложения по внесению изменений в нормативно-правовую плоскость регулирования миграционных процессов в России касаются следующих нюансов обозначенной проблемы:

- расширение границ социальных прав и ответственности для иностранных граждан и лиц без гражданства;

- внедрение практики "форс-мажорного гражданства" для людей, вынужденных отказаться от российского гражданства под угрозой своему существованию, распространение такого порядка на их близких родственников;

- использование "залогового рычага" (с последующим возвратом залога) с императивом получения допуска к трудовой деятельности;

- осуществление государственной поддержки для предпринимателей, работающих в сфрере обеспечения жильем семей мигрантов (гостиницы, хостелы, общежития, центры временного пребывания и т. п.);

- включение в государственную пошлину затрат на проведение практических занятий для государственных, муниципальных служащих и мест- 
ного населения, нацеленных на повышение толерантности к иностранным гражданам.

Социализацию иностранных граждан, в частности, трудовых мигрантов, разумно выстраивать по таким основным параметрам:

- трудовая и профессиональная адаптация на новом месте пребывания, с учетом создания систем самозанятости, профессиональной подготовки и переподготовки, новых рабочих мест;

- гармоничное развитие служб социальной поддержки в системе взаимоотношений мигрантов с местным населением, ориентированное на нивелирование психологических и инфраструктурных проблем на рынке труда на межнациональной и межконфессиональной почве, и т. п.;

- психологическая адаптация и реабилитация мигрантов, предполагающая обеспечение условий для последующей активной и полноценной жизни;

- осуществление исполнительными органами власти субъектов РФ регулярных проверок мест жительства иностранных трудовых мигрантов в местах их коллективного размещения (общежития, гостиницы, хостелы) в целях обеспечения достойных условий их проживания, региональной общественности, национальных диаспор;

- проведение исполнительными органами власти субъектов РФ контрольных мероприятий в части оплаты труда с императивом исключения дискриминации по оплате труда и иных нарушений в трудовой сорере (несвоевременность выдачи, скрытая заработная плата и др.);

- организация исполнительными органами власти субъектов РФ обязательного ежегодного профилактического осмотра трудовых мигрантов в целях предупреждения вспышек опасных инфекционных заболеваний, сохранения здоровья иностранных граждан для реализации их успешной адаптации;

- организация социального сопровождения медицинским обслуживанием иностранных граждан в вопросах оформления медицинской страховки и получения медицинских услуг.

В качестве практических мер противодействия социальной исключённости мигрантов в РФ, пространственной сегрегации и формирования этнических анклавов предлагается:

- проведение встреч с руководителями национально-культурных и религиозных объединений, осуществляющих свою деятельность на территории субъекта РФ/муниципального образования, по вопросам предупреждения этнического и религиозного экстремизма, минимизации последствий его проявления;

- проведение квалифицированными специалистами обучающих семинаров в этой области для актива национально-культурных и религиозных организаций;

- организация мероприятий научно-прикладного характера по вопросам социокультурной адаптации мигрантов (круглых столов, методологических семинаров и др.) с привлечением ученых, работников профильных органов государственной власти и органов местного самоуправления, представителей национально-культурных и религиозных организаций;

- разработка диффреренцированных и адаптированных к региональной экономике механизмов привлечения, отбора и использования иностранной рабочей силы, развитие форм временной пространственной мобильности трудящихся;

- содействие образовательной (учебной) миграции и академической мобильности с включением мер поддержки в трудоустройстве иностранным гражданам - выпускникам вузов по специальностям, востребованным на рынке труда субъекта РФ;

- фрормирование конструктивного взаимодействия между мигрантами и принимающим сообществом путем развития и укрепления культуры межнационального общения;

- создание, развитие и повышение эфрфективности консультативно-совещательных органов по вопросам межнациональных отношений (этнические советы муниципальных районов, городских округов и сельских поселений);

- противодействие нелегальной миграции, включая:

системный мониторинг электронных и печатных СМИ на предмет рекламирования предложений об ускоренном изготовлении миграџионных до- 
кументов о трудоустройстве иностранных граждан, размещения информации экстремистской и националистической направленности;

обеспечение миграционного контроля на оптово-розничных рынках;

проведение регулярных встреч с работодателями по вопросам соблюдения требований федерального законодательства в сфере миграции.

\section{Литература}

1. Бахлов И. В., Бахлова О. В. Совершенствование фредеративных отношений в России в контексте национальной и региональной политики // Ойкумена. Регионоведческие исследования. 2019. № 3. С. 119-126. DOI: 10.24866/1998-6785/2019-3/119-126

2. В Пресс-центре Республики Мордовия презентовали учебно-методическое пособие для мигрантов "Bce мы-Россия". [Электронный ресурс]. URL: http://saransk. bezformata.com/listnews/mordoviya-prezentovali-uchebno-metodicheskoe/41592656/ (дата обращения: 14.06.2019).

3. Демографический ежегодник России. 2017 : стат. сб. / Росстат. М., 2017.

4. Доклад Уполномоченного по правам человека в РФ за 2015 год // Российская газета. 2016. 24 марта.

5. Закон РМ от 01.10.2008 № 94-3 "О Стратегии социально-экономического развития Республики Мордовия на период до 2025 года" (принят ГС РМ 25.09.2008) // СПС Консуль-тантПлюс. [Электронный ресурс]. URL: http://www.consultant.ru/regbase/cgi/ online.cgi?req=doc\&base=RLAW314\&n=16334\&dst=100013\#0572417907392904 (дата обращения: 10.06.2019).

6. Ивахнюк И. В. Предложения к миграционной стратегии России до 2035 г. M.: Центр стратегических разработок, 2017. 80 с. [Электронный ресурс]. URL: https:// csr.ru/wp-content/uploads/2017/09/Migration-Strategy-RU-web-1.pdf (дата обращения: 02.06.2019).

7. Концепщия государственной миграционной политики Российской Федерации на период до 2025 года: утв. Президентом РФ 13 июня 2012 г. // Российская газета. 2012. 14 июня.

8. Леонтьева Т. В России появятся НКО по социальной адаптации мигрантов // Российская газета. 2013. 31 дек.

9. Мониторинг ксенофобских настроений // Официальный сайт Левада-Центра [Электронный ресурс]. URL: http://www.levada.ru/2018/08/27/monitoring-ksenofobskihnastroenij (дата обращения: 07.06.2019).

10. Мордовия: стат. ежегодник / Мордовиястат. Саранск, 2018.

11. Мордовия: стат. ежегодник / Мордовиястат. Саранск, 2019.

12. Об утверждении Плана мероприятий ("дорожной карты") по гармонизации межнациональных и межконфессиональных отношений в Республике Мордовия на 2014-2016 годы и Методических рекомендаций для исполнительных органов государственной власти Республики Мордовия о порядке выявления формирующихся конфоликтов в сфере межнациональных отношений, их предупреждения и действиях, направленных на ликвидацию их последствий: распоряжение Правительства Республики Мордовия от 31.03.2014 № 199-P. [Электронный ресурс]. URL: http://docs.cntd. ru/document/446563955 (дата обращения: 30.10.2019).

13. Постановление Правительства РМ от 18.11.2013 № 507 "Об утверждении государственной программы "Гармонизация межнациональных и межконфессиональных отношений в Республике Мордовия"'" (с изм. на 25.02.2019). [Электронный ресурс]. URL: http://docs.cntd.ru/document/424029654 (дата обращения: 01.11.2019).

14. Регионы России. Социально-экономические показатели. 2018 : стат. сб. / Росстат. М., 2018.

15. Российский статистический ежегодник. 2018 : стат. сб. / Росстат. М., 2018.

16. Рязанцев С. В. Современный демографический и миграционный портрет Северного Кавказа. Ставрополь: Сервисшкола, 2003. 375 с.

17. Сазонова О. А. Адаптационная и интеграционная политика в отношении иностранных граждан: особенности правового регулирования в Российской Федерации // Studia Humanitatis. 2017. № 3. [Электронный pecypc]. URL: http://st-hum.ru/content/ sazonova-oa-adaptacionnaya-i-integracionnaya-politika-v-otnoshenii-inostrannyhgrazhdan (дата обращения: 01.11.2019).

18. Скоробогатова В. И. К вопросу об интеграции мигрантов: какая модель подходит России? // Мигращионное право. 2015. № 4. С. 5-7.

19. Социологи объяснили рост популярности лозунга "Россия для русских" // Московский комсомолец. [Электронный ресурc]. URL: https://www.mk.ru/social/2018/08/27/ sociologi-obyasnili-rost-populyarnosti-lozunga-rossiya-dlya-russkikh.html (дата обращения: 07.06.2019).

20. Указ Президента РФ от 19.12.2012 № 1666 (ред. от 06.12.2018) "О Стратегии государственной национальной политики Российской Федерации на период до 2025 
года" // СПС КонсультантПлюс. [Электронный ресурс]. URL: http://www.consultant.ru (дата обращения: 10.06.2019).

21. Управление по вопросам миграции МВД России по Республике Мордовия // Официальный сайт. [Электронный ресурс]. URL: https://13.мвд.pp/gumvd/structure/ item/7759441 (дата обращения: 02.06.2019).

22. Bijedić T., Piper A. Different Strokes for Different Folks: The Job Satisfaction of the Self-employed and the Intersection of Gender and Migration Background // International Journal of Gender and Entrepreneurship. 2019. Vol. 11(3). P. 227-247. DOI: 10.1108/ IJGE-01-2019-0021/full/html

23. Colas M., Ge S. Transformations in China's Internal Labor Migration and Hukou System // Journal of Labor Research. 2019. Vol. 40(3). P. 296-331. DOI: 10.1007\%2Fs12122019-9283-5

24. Islam A., Palacios Lopez A., Amin M. Decomposing the Labour Productivity Gap between Migrant-Owned and Native-Owned Firms in Sub-Saharan Africa // Journal of Development Studies. 2019. Vol. 55(9). P.2065-2082. DOI: 10.1080/00220388.2018.1520215

25. Lozej M. Economic Migration and Business Cycles in a Small Open Economy with Matching Frictions // Economic Modelling. 2019. Vol. 81. P. 604-620. DOI: 10.1016/j. econmod.2018.07.012

26. Holliday J., Hennebry J., Gammage S. Achieving the Sustainable Development Goals: Surfacing the Role for a Gender Analytic of Migration // Journal of Ethnic and Migration Studies. 2019. Vol. 45(14). P. 2551-2565. DOI: 10.1080/1369183X.2018.1456720.

\section{Транслитерация по ГОСТ 7.79-2000 Система Б}

1. Bakhlov I. V., Bakhlova O. V. Sovershenstvovanie federativnykh otnoshenij v Rossii v kontekste natsional'noj i regional'noj politiki // Ojkumena. Regionovedcheskie issledovaniya. 2019. № 3. S. 119-126. DOI: 10.24866/1998-6785/2019-3/119-126

2. V Press-tsentre Respubliki Mordoviya prezentovali uchebno-metodicheskoe posobie dlya migrantov "Vse my - Rossiya". [Ehlektronnyj resurs]. URL: http://saransk.bezformata.com/listnews/mordoviya-prezentovali-uchebno-metodicheskoe/41592656/ (data obrashheniya: 14.06.2019).

3. Demograficheskij ezhegodnik Rossii. 2017 : stat. sb. / Rosstat. M., 2017.

4. Doklad Upolnomochennogo po pravam cheloveka $\mathrm{v}$ RF za 2015 god // Rossijskaya gazeta. 2016. 24 marta.

5. Zakon RM ot 01.10.2008 № 94-Z "O Strategii sotsial'no-ehkonomicheskogo razvitiya Respubliki Mordoviya na period do 2025 goda" (prinyat GS RM 25.09.2008) // SPS Konsul'-tantPlyus. [Ehlektronnyj resurs]. URL: http://www.consultant.ru/regbase/cgi/ online.cgi?req=doc\&base=RLAW314\&n=16334\&dst=100013\#0572417907392904 (data obrashheniya: 10.06.2019).

6. Ivakhnyuk I. V. Predlozheniya k migratsionnoj strategii Rossii do 2035 g. M.: TSentr strategicheskikh razrabotok, 2017. 80 s. [Ehlektronnyj resurs]. URL: https://csr. $\mathrm{ru} / \mathrm{wp}$-content/uploads/2017/09/Migration-Strategy-RU-web-1.pdf (data obrashheniya: 02.06.2019).

7. Kontseptsiya gosudarstvennoj migratsionnoj politiki Rossijskoj Federatsii na period do 2025 goda: utv. Prezidentom RF 13 iyunya 2012 g. // Rossijskaya gazeta. 2012. 14 iyunya.

8. Leont'eva T. V Rossii poyavyatsya NKO po sotsial'noj adaptatsii migrantov // Rossijskaya gazeta. 2013. 31 dek.

9. Monitoring ksenofobskikh nastroenij // Ofitsial'nyj sajt Levada-TSentra [Ehlektronnyj resurs]. URL: http://www.levada.ru/2018/08/27/monitoring-ksenofobskih-nastroenij (data obrashheniya: 07.06.2019).

10. Mordoviya: stat. ezhegodnik / Mordoviyastat. Saransk, 2018.

11. Mordoviya: stat. ezhegodnik / Mordoviyastat. Saransk, 2019.

12. Ob utverzhdenii Plana meropriyatij ("dorozhnoj karty") po garmonizatsii mezhnatsional'nykh i mezhkonfessional'nykh otnoshenij v Respublike Mordoviya na 2014-2016 gody i Metodicheskikh rekomendatsij dlya ispolnitel'nykh organov gosudarstvennoj vlasti Respubliki Mordoviya o poryadke vyyavleniya formiruyushhikhsya konfliktov v sfere mezhnatsional'nykh otnoshenij, ikh preduprezhdeniya i dejstviyakh, napravlennykh na likvidatsiyu ikh posledstvij: rasporyazhenie Pravitel'stva Respubliki Mordoviya ot 31.03.2014 № 199-R. [Ehlektronnyj resurs]. URL: http://docs.cntd.ru/document/446563955 (data obrashheniya: 30.10.2019).

13. Postanovlenie Pravitel'stva RM ot 18.11.2013 № 507 "Ob utverzhdenii gosudarstvennoj programmy "Garmonizatsiya mezhnatsional'nykh i mezhkonfessional'nykh otnoshenij v Respublike Mordoviya"'" (s izm. na 25.02.2019). [Ehlektronnyj resurs]. URL: http:// docs.cntd.ru/document/424029654 (data obrashheniya: 01.11.2019).

14. Regiony Rossii. Sotsial'no-ehkonomicheskie pokazateli. 2018 : stat. sb. / Rosstat. M., 2018.

15. Rossijskij statisticheskij ezhegodnik. 2018 : stat. sb. / Rosstat. M., 2018. 
16. Ryazantsev S. V. Sovremennyj demograficheskij i migratsionnyj portret Severnogo Kavkaza. Stavropol': Servisshkola, 2003. 375 s.

17. Sazonova O.A. Adaptatsionnaya i integratsionnaya politika v otnoshenii inostrannykh grazhdan: osobennosti pravovogo regulirovaniya v Rossijskoj Federatsii // Studia Humanitatis. 2017. № 3. [Ehlektronnyj resurs]. URL: http://st-hum.ru/content/sazonova-oa-adaptacionnaya-i-integracionnaya-politika-v-otnoshenii-inostrannyh-grazhdan (data obrashheniya: 01.11.2019).

18. Skorobogatova V. I. K voprosu ob integratsii migrantov: kakaya model' podkhodit Rossii? // Migratsionnoe pravo. 2015. № 4. S. 5-7.

19. Sotsiologi ob"yasnili rost populyarnosti lozunga "Rossiya dlya russkikh" // Moskovskij komsomolets. [Ehlektronnyj resurs]. URL: https://www.mk.ru/social/2018/08/27/sociologi-obyasnili-rost-populyarnosti-lozunga-rossiya-dlya-russkikh.html (data obrashheniya: 07.06.2019).

20. Ukaz Prezidenta RF ot 19.12.2012 № 1666 (red. ot 06.12.2018) "O Strategii gosudarstvennoj natsional'noj politiki Rossijskoj Federatsii na period do 2025 goda" // SPS Konsul'tantPlyus. [Ehlektronnyj resurs]. URL: http://www.consultant.ru (data obrashheniya: 10.06.2019).

21. Upravlenie po voprosam migratsii MVD Rossii po Respublike Mordoviya // Ofitsial'nyj sajt. [Ehlektronnyj resurs]. URL: https://13.mvd.rf/gumvd/structure/item/7759441 (data obrashheniya: 02.06.2019).

22. Bijedić T., Piper A. Different Strokes for Different Folks: The Job Satisfaction of the Self-employed and the Intersection of Gender and Migration Background // International Journal of Gender and Entrepreneurship. 2019. Vol. 11(3). P. 227-247. DOI: 10.1108/IJGE-01-2019-0021/full/html

23. Colas M., Ge S. Transformations in China's Internal Labor Migration and Hukou System // Journal of Labor Research. 2019. Vol. 40(3). P. 296-331. DOI: 10.1007\%2Fs12122019-9283-5

24. Islam A., Palacios Lopez A., Amin M. Decomposing the Labour Productivity Gap between Migrant-Owned and Native-Owned Firms in Sub-Saharan Africa // Journal of Development Studies. 2019. Vol. 55(9). P. 2065-2082. DOI: 10.1080/00220388.2018.1520215

25. Lozej M. Economic Migration and Business Cycles in a Small Open Economy with Matching Frictions // Economic Modelling. 2019. Vol. 81. P. 604-620. DOI: 10.1016/j.econmod.2018.07.012

26. Holliday J., Hennebry J., Gammage S. Achieving the Sustainable Development Goals: Surfacing the Role for a Gender Analytic of Migration // Journal of Ethnic and Migration Studies. 2019. Vol. 45(14). P. 2551-2565. DOI: 10.1080/1369183X.2018.1456720. 
Бахлов И. В., Кильдюшкина И. Г., Липатова Л. Н. Интеграция и социальная адаптация мигрантов: основы государственной политики и опыт Республики Мордовия.

В статье исследуются аспекты государственной миграционной политики Российской Федерации в части содействия социализации мигрантов, формирования конструктивного диалога между ними и принимающей стороной, противодействия их социальной исключенности, пространственной сегрегации и создания этнических анклавов в контексте обеспечения экономической безопасности Республики Мордовия. Обосновывается необходимость создания эффективной, универсальной модели социальной адаптации и интеграции мигрантов в российское общество. Определяются ориентиры и механизмы федерального, регионального и местного уровней управления, в том числе нормативно-правового регулирования миграционных процессов и практические меры по подготовке современных государственных институтов России к социализации иностранных граждан и лиц без гражданства.

Ключевые слова: государственная миграционная политика, соииальная адаптация, социализация мигрантов, социальная исключённость, пространственная сегрегаиия, этнический анклав, Российская Федераиия, Республика Мордовия, регулирование мигращионных процессов

Bakhlov I. V., Kildiyshkina I. G., Lipatova L. N. Integration and Social Adaptation of Migrants: the Basics of Public Policy and the Experience of the Republic of Mordovia.

The article examines the aspects of the relationship of the spheres of state migration policy of Russia in the part of the promoting the socialization of migrants, the formation of constructive dialogue between them and the host, counteracting their social exclusion, spatial segregation and creating ethnic enclaves in the context of ensuring the economic security of The Republic of Mordovia. The need is justified creating an effective, universal model social adaptation and integration of migrants in Russian society. The guidelines and mechanisms of the federal, regional and local levels of government are determined, including the legal regulation of migration processes and practical measures to prepare modern state institutions of Russia for the socialization of foreign citizens and stateless persons.

Key words: state migration policy, social adaptation, socialization of migrants, social exclusion, spatial segregation, ethnic enclave, Russian Federation, The Republic of Mordovia, regulation of migration processes

Для цитирования: Бахлов И. В., Кильдюшкина И. Г., Липатова Л. Н. Интегращия и социальная адаптация мигрантов: основы государственной политики и опыт Республики Мордовия // Ойкумена. Регионоведческие исследования. 2020. № 1. С. 66-78. DOI: 10.24866/1998$6785 / 2020-1 / 66-78$

For citation: Bakhlov I. V., Kildiyshkina I. G., Lipatova L. N. Integration and Social Adaptation of Migrants: the Basics of Public Policy and the Experience of the Republic of Mordovia // Ojkumena. Regional researches. 2020. № 1. P. 66-78. DOI: $10.24866 / 1998-6785 / 2020-1 / 66$ 78 


\section{"Женщины для утешения" как часть феминистского движения корейской диаспоры в Японии}

Актуальность данного исследования заключается в ускоренном развитии фреминистского движения в Республике Корея. В настоящее время феминистки активно борются за свои права в различных сдерах общественной жизни, и проблема "женщин для утешения" не обошла их стороной. Однако борьба кореянок за свои права и обсуждение проблемы "женщин для утешения" проходили не только на территории Республики Корея, но и в Японии. Исходя из этого, цель данного исследования - рассмотреть проблему "женщин для утешения" в контексте феминистского движения корейской диаспоры в Японии с окончания Второй мировой войны по настоящее время.

Для сбора, систематизации и анализа материала по проблеме "женщин для утешения" и по фреминистскому движению корейской диаспоры в Японии был использован информационно-аналитический метод. Этот метод также был применен при переводе свидетельских показаний бывших женщин для утешения и изучении таких организаций, как "Ассоциация корейских женщин в Японии", "Ассоциация корейских матерей в Кавасаки", "Ассоциация по изучению исторических шедевров, написанных корейскими женщинами", "Корейский совет по делам женщин, призванных к сексуальному рабству Японией" и др. Вдобавок автором был использован системный подход, который позволил исследовать проблему "женщин для утешения" как отдельную систему и выявить связь её элементов с феминистским движением корейской диаспоры в Японии. При рассмотрении связи между проблемой "женщин для утешения" и феминистского движения как с исторической, так и с теоретической точек зрения важную роль сыграли принципы историко-фрилософрского анализа. Согласно этим принципам, борьба за права кореянок в Японии в рамках проблемы "женщин для утешения" исследуется с учетом исторического, культурного и фрилософского контекста.

Условия жизни корейской диаспоры в Японии после окончания Второй мировой войны, проблема "женщин для утешения" и фреминистское движение кореянок в Японии в наибольшей степени отражены в трудах зарубежных авторов. В своей работе "Осуществление гражданских прав: корейцы в Японии" ("Exercising Citizenship: Koreans Living in Japan") И. Чунг рассказывает, при каких условиях корейцы могли получить японское гражданство после Второй мировой войны. Автор приводит статистику, сколько корейцев, проживавших в то время в Японии, смогли получить гражданство [6]. Условия получения японского гражданства подробно описаны и в работе Т. А. Васильевой "Иммиграционное законодательство и миграционная политика Японии" [1]. Исследование С. Рьянг и Дж. Ли "Диаспора без Родины: быть корейцем в Японии" ("Diaspora without Homeland: Being Korean in Japan") посвящено статусу корейской диаспоры в Японии: как жили корейцы после Второй мировой войны, какие имели права и т. д. [13].

Проблеме "женщин для утешения" посвящен ряд исследований, среди которых стоит отметить работу Х. Хаяши "Разногласия в Японии по поводу проблемы "женщин для утешения" и ее осознание в истории" ("Disputes in Japan over the Japanese Military 'Comfort Women' System and Its Perception in History") [8]. В дополнение тому, В. Казуко в своей работе "Милитаризм, колониализм и торговля женщинами: "женщины для утешения", находившиеся в секс-рабстве у японских военных" ("Militarism, colonialism, and the trafficking

\section{(С) Литвиниева А. И., 2020}

ЛИТВИНЦЕВА Анастасия Игоревна, магистрант кафедры Тихоокеанской Азии Дальневосточного федерального университета (2. Владивосток). E-mail: L.I.A.96@mail.ru 
of women: "Comfort women" forced into sexual labor for Japanese soldiers") pacсказывает об истории "женщин для утешения", первых свидетельских показаниях и о том, как отреагировало правительство Японии на требования понести ответственность за свои действия [11].

Феминистское движение корейской диаспоры в Японии описывается такими авторами, как Дж. Баллок, А. Кано и Дж. Велкер. В своей книге "Переосмысление японского феминизма" ("Rethinking Japanese Feminisms") исследователи затрагивают вопросы о том, как связаны начало феминистского движения корейской диаспоры в Японии и проблема "женщин для утешения". Авторы также уделяют внимание организациям, призванным бороться за права женщин [4]. О природе фоминизма и причинах его распространения среди кореянок более подробно рассказывается в исследовании М. Чинг "Народный феминизм: движение кореянок за гендерное и классовое освобождение" ("Minjung feminism: Korean women's movement for gender and class liberation") [5]. Помимо того, о помощи феминисток бывшим "женщинам для утешения" рассказывает П. Мин в своем исследовании "Женщины для утешения как точка пересечения колониальной власти, пола и класса" ("Comfort Women: The Intersection of Colonial Power, Gender, and Class") [12].

Таким образом, зарубежных исследований, которые посвящены проблеме "женщин для утешения", достаточно много. Что касается фреминистского движения корейской диаспоры в Японии, то научные труды по данной проблематике практически отсутствуют. В дополнение к этому стоит отметить, что исследований, посвященных нынешней ситуации проблемы "женщин для утешения" в рамках феминистского движения, также практически нет, что подчеркивает актуальность выбранной проблематики.

С 1910 по 1945 гг. Корейский полуостров находился под властью Японии (это время также известно как "колониальный режим Японии"). В эти годы Корея не обладала собственным суверенитетом, а власть принадлежала японскому генерал-губернатору. Более того, вплоть до окончания Второй мировой войны корейцы подвергались дискриминации и жили под жёсткой авторитарной политикой японцев [2, с. 257].

После капитуляции Японии больше половины корейцев вернулись на свою родину, однако политическая нестабильность на территории Корейского полуострова заставила часть из них отложить репатриацию в надежде на то, что позже они смогут вернуться в единое государство. Ввиду того, что бывшие колониальные подданные воспринимались как временные жители и изгнанники, в корейской диаспоре фрактически отсутствовала какая-либо безопасность.

Более того, в 1947 г. японцами был введен закон о регистрации: если в годы колониального господства люди получали японское гражданство, то в послевоенное время люди, пожелавшие остаться на территории Японии, должны были пройти обязательную процедуру регистрации иностранных граждан; а после вступления в силу Сан-Францисского мирного договора в 1952 г. корейцы в Японии и вовсе были лишены японского гражданства, что также повлекло за собой невозможность пользоваться различными услугами социального обеспечения: социальным жильем, медицинским страхованием, правом голоса, работой в госструктурах и т. д. Такого рода дискриминация направлялась даже на последующие поколения корейцев, которые с рождения воспитывались в японской языковой среде и культуре [1, с. 193]. Лишь в 1965 г. после установления дипломатических отношений между Республикой Корея (РК) и Японией корейская диаспора получила право на постоянное проживание на территории Японии, но при условии принадлежности к своему государству - Республике Корея [7].

"Вытесненным" из японского общества корейцам удалось создать самодостаточную этническую общину с развитой инфраструктурой, в которую входили банки, школы, культурные учреждения, религиозные объединения и т. д. Как правило, они были вовлечены в небольшое семейное дело, например, в ресторанный бизнес или в работу на заводе по производству изделий из пластмассы; либо устраивались разнорабочими на непостоянной основе. Несмотря на успехи, свободное владение японским языком и знание японской культуры, а также долгосрочное проживание в Японии, корейцы все еще оставались "невидимыми" и непризнанными среди японского населения. Однако 
эти условия лишь укрепляли взаимоотношения внутри корейской диаспоры, что в дальнейшем стало одним из толчков начала движения женщин против неравенства [13, с. 98].

Неопределенный статус японских корейцев (гражданами какой страны они являются) и разделение Корейского полуострова на два независимых государства побудило корейцев находиться в постоянном поиске себя. Вдобавок такая неопределенность стала причиной большей вовлеченности корейцев в националистические движения, а также в протесты против подавления со стороны японских властей. В это время начало зарождаться участие женщин в политической сорере под эгидой двух этнонациональных организаций: "Ассоциации корейских женщин в Японии" ("The Association of Korean Women in Japan") и "Демократического объединения корейских женщин в Японии" ("The Democratic Union of Korean Women in Japan") [4, c. 234].

Дальнейшие поколения корейцев, которые рождались в Японии, начали участвовать в массовых движениях, где главной целью было отстаивать права человека, а также донести до японцев, что корейцы являются такими же гражданами, а не экспатриантами. Движение корейцев за свои гражданские права впервые возникло в городе Кавасаки, где молодой кореец второго поколения из-за дискриминации на рабочем месте подал иск против крупной электрической корпорации. Конфликта удалось избежать, так как обе стороны договорились о перемирии, но благодаря этому случаю начали образовываться различные организащии по защите прав человека. Эти организации появлялись в городах, где проживало наибольшее количество представителей корейской диаспоры. Среди них можно отметить такие города, как Осака, Киото и Токио [6, с. 173].

Что касается кореянок, то они также основывали свои организации, целью которых являлась защита прав женщин. Например, "Ассоциация корейских матерей в Кавасаки" ("The Korean Mother's Association in Kawasaki") была основана для того, чтобы бороться за уважение этнического происхождения и индивидуальности своих детей, которые обучались в школах Японии [19, с. 141].

Однако, несмотря на тот фракт, что женщины всегда принимали активное участие в различных корейских движениях за справедливость и равенство, их позищия в качестве активисток была неоднозначной. Как подчеркивали феминистки, "политическое" по природе своей означало вовлеченность только мужчины, поэтому участвовать в политических вопросах женщинам удавалось лишь через создание организаций, подобных "Организации корейских матерей в Кавасаки". Более того, основанное на материнстве стремление быть вовлеченными в политическую сореру отражало один из главных аспектов жизни корейской женщины: преданность своей семье, в особенности - деТЯМ.

В 1987 г. была офрициально основана "Ассоциация корейских женщин в Японии за демократию" ("The Association of Korean Women in Japan for Democracy"), члены которой выступали против диктатуры в Республике Корея [5, с. 420]. Некоторое время спустя, под влиянием роста выступлений женщин в Республике Корея, которые протестовали против насилия в свой адрес, кореянки в Японии также начали часто высказывать свое недовольство гендерным неравенством, включая этническую дискриминацию.

Еще один пример - "Ассоциация по изучению исторических шедевров, написанных корейскими женщинами" ("The Association for Reading Korean Women's History"). Женщины, которые входили в эту организацию, устраивали совместные встречи, чтобы читать и переводить исторические труды корейских женщин, публиковавшихся в Женском университете Ихва. Также членами этой организации ежеквартально публиковался инорормационный бюллетень на японском языке под названием "Женское общение" ("Women's Communication"), в котором обсуждалось стремление женщин иметь больше свободы; но главное - была предпринята попытка политизировать принудительную проституцию корейских женщин, которые сейчас известны как "женщины для утешения" [4, с. 236].

Многим известно, что в период с 1932 по 1945 гг. японцами создавались так называемые "станции утешения"-военные бордели, куда привозили женщин с оккупированных территорий Восточной и Юго-Восточной Азии. На 
данных станциях их принуждали работать в качестве "женщин для утешения", т.е. быть секс-рабынями [12, с. 940]. До сих пор неизвестно точное количество "женщин для утешения": согласно подсчетам японской стороны, в борделях было задействовано примерно 20 тыс. женщин, однако китайская сторона утверждает, что было вовлечено как минимум 400 тыс. женщин [3].

Нередки были случаи самоубийства девушек, т. к. никакого другого варианта они больше не видели. Так, в интервью 1998 г. Кимико Канеда вспоминала следующее: "Мой отец был кореец, а мама - японка, и всю жизнь до начала войны мы с семьей жили на территории Кореи. Затем я попала на одну из "станций утешения". Как я себя чувствовала? Я чувствовала себя так, будто меня привезли в то место, чтобы убить. Я не могла не плакать. Ни одна из девушек не произносила ни слова, но многие плакали. В первую ночь солдаты пришли в мою комнату, но я сопротивлялась изо всех сил. Один из них попытался сорвать с меня одежду, но я начала кричать: "Нет! Нет! Не трогай меня!",- и тогда он ушёл. Но другой солдат был пьян, и у меня не было никакой возможности ему сопротивляться, так как он достал нож и угрожал убить, если я не сделаю то, что он хочет. Чуть позже он ранил меня ножом в грудную клетку - его забрала военная полиция, а меня, истекавшую кровью, отвезли в лазарет. В конце концов, мне стало лучше, но мое тело так и не окрепло, хоть после освобождения прошло очень много лет. Я также помню девочек, которые были ещё совсем маленькими и которые по ночам, захлёбываясь слезами и страхом, звали своих матерей. В те годы моё сердце было разбито" [18].

Однако, как уже было сказано выше, проблема "женщин для утешения" была поднята на политической арене лишь в 1990 г. после создания "Корейского совета по делам женщин, призванных к военному сексуальному рабству Японией" ("The Korean Council for the Women Drafted for Military Sexual Slavery by Japan") [22]. Сразу после основания Совета его глава Юн Чон Ок прибыл в Токио, чтобы встретиться с женщинами, которым приходилось работать на "станциях утешения". Часть из них имела отношение к созданию информационного бюллетеня "Женское общение", другие были активистками, которые не принадлежали к какой-либо женской организации. Всего на встречу с Юн Чон Соком прибыло 17 женщин, и после его выступления у них уже не было сомнений, что необходимо предпринимать меры по данной проблеме. Они начали с переводов интервью с Юн Чон Соком, которые затем были опубликованы в небольших буклетах под названием "Мы никогда не забудем: корейские женщины для утешения" ("We Never Forget: Korean Military Comfort Women") $[4$, c. 236].

Через год в Токио была основана еще одна организащия "Сообщество кореянок по проблеме женщин для утешения" ("The Korean Women's Network on the Comfort Women Issue", сокращённо - "Uriyosong Network") [11, c. 3]. В одном их своих первых выступлений они говорили следующее: "Несмотря на то, что колониальный режим давно в прошлом, проблема расизма и угнетения до сих пор существует в отношении корейцев в Японии. Более того, проблема "женщин для утешения" все еще не решена, и пусть с опозданием, но с этого момента мы начинаем предпринимать попытки в сторону защиты кореянок в Японии. Нам стыдно, что мы не сделали этот шаг раньше, но всё же спустя 46 лет после окончания войны мы, наконец, можем встать против этой политики" [4, с. 237].

Через месяц на собрании Сообщества выступила Ким Хак Сун - первая женщина из сотен других женщин Кореи, Китая, Тайваня, Филиппин, Индонезии и других стран, которая осмелилась публично рассказать о своей работе в качестве "женщины для утешения" и потребовать от Японии понести ответственность за свои действия [21].

В 1992 г. "Сообщество кореянок по проблеме женщин для утешения" организовало трёхдневную горячую линию в сотрудничестве с тремя другими женскими организациями, в ходе которой удалось получить более двухсот свидетельских показаний не только бывших "женщин для утешения", но и японских солдат [4, с. 238].

Во время визита премьер-министра Японии Киити Миядзава в Сеул Сообщество обратилось к правительству Японии с просьбой ответить на запросы "Корейского совета по делам женщин, призванных к военному сексуальному рабству Японией", а именно: дать официальные извинения корейской сторо- 
не, выплатить компенсацию, поставить памятник "женщинам для утешения" и начать рассказывать в японских школах о данном периоде на уроках истории [9].

Члены Сообщества проводили исследования не только на территории Японии и Республики Корея, но и в других странах, используя сохранившиеся исторические записи и интервьюируя оставшихся в живых "женщин для утешения". Дальше - больше: Сообщество выступало с докладами на Азиатской конференции солидарности по проблеме "женщин для утешения"; предоставило подробный отчет Комитету ООН по ликвидации дискриминации в отношении женщин в 1994 г.; организовало рабочее совещание на четвёртой Всемирной конференции по положению женщин в Пекине в 1995 г. и т. д. Деятельность "Сообщества кореянок по проблеме женщин для утешения" велась не только на японском, корейском и английском, но и на других языках, что позволяло ему играть роль посредника в защите интересов женщин Кореи, Японии, Китая и других стран [4, с. 238].

Как уже было упомянуто, с момента создания Сообщества в 1991 г. движение женщин начало возрастать: они стали чаще говорить о значимости женщины и неравноправном отношении к ним в азиатском обществе. Интерес к феминизму у женщин, входящих в Сообщество, вырос благодаря чтению книги "Второй пол" ("The Second Sex"), которая была написана орранцузским философом Симоной де Бовуар в 1949 г. Стоит отметить, что эта книга считается отправной точкой феминизма второй волны, где женщины поднимали проблемы, связанные не только с неравенством в обществе, но и с репродуктивным правом и правом на желаемое рабочее место. Таким образом, женщины-члены Сообщества выступали не только за всех "женщин для утешения", но и за равенство в обществе в целом [14].

Так, одна из основательниц Сообщества Ким Ён Хи в интервью от 2004 г. говорила следующее: "Все домашние дела приходилось выполнять мне, а не моим братьям. Например, во время проведения Чеса (корейский ритуал, посвящённый чествованию своих предков) я и другие женщины нашей семьи готовили еду на всех, однако мы были исключены из службы, так как в ней могли участвовать только мужчины. Как и многие корейцы, родившиеся в Японии, я ходила в японскую школу и носила японское имя. Во время учебы в университете я присоединилась к группе молодых корейцев, которые так же, как и я, чувствовали себя изгоями в японском обществе. Впоследствии я отказалась от своего японского имени и во всех своих дальнейших выступлениях использовала только корейское. Я боролась за права человека, но меня также интересовали взгляды женщин. К сожалению, члены студенческой организации, к которой я принадлежала, считали, что "освобождение" женщин будет приоритетным направлением лишь только после воссоединения Кореи в единое государство. Поэтому, когда некоторое время спустя я услышала о начале движения "женщин для утешения", я подумала, что это "подарок с небес", так как эта проблема, вдобавок, позволила бороться и выступать за равноправие женщин" [4, с. 240]. Таким образом, основываясь на вышеизложенном, мы можем предположить, что феминистское движение кореянок в Японии началось с создания "Сообщества кореянок по проблеме женщин для утешения", целью которого была не только поддержка пострадавших от японцев во Второй мировой войне женщин, но и борьба за свои права.

Также проблема "женщин для утешения" помогла кореянкам в Японии почувствовать поддержку, так как до начала 90-х гг. членами различных организаций были преимущественно мужчины. Следовательно, можно снова предположить, что Сообщество стало первой организацией, которая начала представлять коллективную идентичность корейских женщин в Японии. Им удалось найти единомышленниц в поиске и познании себя как женщин. Вместе им было легче выступать против дискриминации и неравенства, а также требовать от Японии понести ответственность за свои действия на "станциях утешения".

Однако со временем Сообщество как женская организация начало терять свою популярность. Во-первых, стали образовываться другие женские организации, которые выступали за равноправие женщин и в защиту "женщин для утешения" в том числе, поэтому Сообщество утратило свою самобытность. Во-вторых, несмотря на общую идею поддерживать бывших "женщин 
для утешения", возникли проблемы внутри самой организации: часть женщин была в большей части привержена феминистским идеям (больше прав и свобод женщинам), а другая часть сосредотачивала свое внимание на этнической принадлежности (важность не чувствовать себя чужаком в Японии). Таким образом, в 1998 г. "Сообщество кореянок по проблеме женщин для утешения" было официально распущено [4, с. 242].

Как известно, проблема "женщин для утешения" до сих пор остро воспринимается в корейском обществе. В 1990-е гг. японцы неоднократно приносили извинения за жестокое отношение к женщинам, но денежная компенсация, тем не менее, никому не была выплачена. Вдобавок, в 2007 г. премьер-министр Японии заявил, что принуждение женщин к проституции не было официально зарегистрировано. Однако чуть позже он все же согласился с тем, что на "станциях утешения" не раз нарушались права человека $[8$, с. 123].

В декабре 2011 г. перед посольством Японии в Сеуле была воздвигнута статуя молодой девушки, чтобы почтить память "женщин для утешения". Однако японская сторона несколько раз обращалась к правительству Республики Корея с просьбой убрать эту статую [17]. Через 5 лет, в декабре 2016 г. перед консульством Японии в Пусане была установлена еще одна статуя в память о "женщинах для утешения" идентичная той, что находится в Сеуле. На это резко отреагировала японская сторона, отозвав своего посла из Сеула и генконсула из Пусана на некоторое время [10].

О готовности начать выплачивать денежную компенсацию Япония официально заявила в 2015 г. Более того, японское правительство также признало всю ответственность за сексуальную эксплуатацию женщин на "станциях утешения". Однако сделка между корейским президентом Пак Кын Хе и японским премьер-министром Пак Кын Хе вызвала критику со стороны кореянок, так как они посчитали, что их мнение и требования не были учтены в полной мере. Из-за этого договоренности между Республикой Корея и Японией так и не были достигнуты, а в 2017 г. президент Республики Корея Мун Чжэ Ин выступил с заявлением, что ранее подписанное соглашение в память о "женщинах для утешения" является неприемлемым для жителей страны и нуждается в тщательной доработке [16].

Говоря о нынешнем отношении к проблеме "женщин для утешения", стоить отметить, что большая часть недовольства выражается кореянками, проживающими на территории Республики Корея. С недавних пор страну захлестнула волна радикального фоминизма, характеризующаяся появлением "поколения сампо", отказывающегося от брака, детей и половых отношений с мужчинами. Вдобавок в настоящее время кореянки очень остро реагируют на любое кажущееся им несправедливым отношение к женщине, поэтому проблема "женщин для утешения" не оставила их равнодушными [20].

В 2017 г. в Республике Корея проживало 37 кореянок, работавших на "станциях утешения" во Второй мировой войне. Однако, несмотря на почтенный возраст, некоторые из них до сих пор участвуют в протестах против Японии. Одна из выживших, Ок Сун Ли так вспоминает прошлое: "Каждый раз, когда я не слушалась солдат и пыталась отказываться от интимных отношений с ними, меня били кожаным ремнем. Такое насилие надо мной продолжалось в течение 5 лет. Однажды мне пришлось лежать в лазарете в течение двух месяцев, так как я заразилась сифилисом. Но после лечения я потеряла какую-либо возможность иметь детей, т. к. мне приходилось снимать с себя всю одежду, а затем сидеть над тазиком с испаряющейся ртутью" [15].

Молодому поколению феминисток хорошо знакомы истории Ок Сун Ли и других бывших "женщин для утешения". Они неоднократно протестовали напротив японского посольства в Сеуле, заявляя, что "новое поколение берет эту нерешенную проблему в свои руки и будет продолжать бороться не только за оставшихся в живых кореянок, но и за всех "женщин для утешения" в целом". Более того, для молодых феминисток важно бороться за права бывших "женщин для утешения" для того, чтобы "чувствовать единство всех женщин и в дальнейшем бороться за свои права" [15].

Подводя итог, мы можем сказать, что проблема "женщин для утешения" начала обсуждаться на политической арене лишь в начале 1990-х гг., когда женщины начали проникаться феминистическими идеями и бороться за свои права. Несмотря на то, что уже в 1970-х гг. в Японии стали появляться пер- 
вые женские сообщества, в которых женщины могли почувствовать поддержку других и поделиться своими мыслями, исследователями подчеркивается, что феминистское движение было скорее "редким исключением" [4, с. 235].

Первой официальной организацией, которая пыталась бороться за равноправие женщин от Японии, а также выступать с требованиями понести ответственность за деятельность во Второй мировой войне, было "Сообщество кореянок по проблеме женщин для утешения" [11, с. 3]. Благодаря созданию данной организации женщины осмелились рассказать свои истории, которых они стыдились на протяжении многих лет. Помимо этого, Сообщество посодействовало дальнейшему развитию феминистического движения кореянок в Японии.

После распада Сообщества женщины продолжили продвигать проблему "женщин для утешения", но взгляды и протесты фреминисток стали больше продвигаться на территории Республики Корея, а не Японии, т.к. часть кореянок вернулась на свою родину. Вдобавок в настоящее время в Республике Корея распространились идеи радикального феминизма, которые также затрагивают защиту бывших "женщин для утешения" [15].

\section{Литература}

1. Васильева Т. А. Иммиграционное законодательство и миграционная политика Японии / Т.А. Васильева // Труды Института государства и права РАН. 2010. №3. C. 185-208.

2. Курбанов С. О. История Кореи с древности до начала XXI века / С.О. Курбанов. СПб.: Изд-во С.-Петерб. ун-та, 2009. 680 с.

3. Станции утешения для японских солдат // Военное обозрение [Электронный pecypc]. URL: https://topwar.ru/136069-stancii-utesheniya-dlya-yaponskih-soldat.html (дата обращения 11.11.2019).

4. Bullock J., Kano A., Welker J. Rethinking Japanese Feminisms. Honolulu: University of Hawaii Press, 2018. 310 p.

5. Ching M. Minjung feminism: Korean women's movement for gender and class liberation // Women's Studies International Forum. 1995. Vol. 18(4). P. 417-430.

6. Chung E.A. Exercising Citizenship: Koreans Living in Japan // Asian Perspective. 2000. Vol. 24 (4). P. 159-178.

7. Hawon, J. The Special Permanent Residents in Japan: Zainichi Korean [Электронный ресурс]. URL: http://yris.yira.org/comments/2873 (дата обращения 10.11.2019).

8. Hayashi H. Disputes in Japan over the Japanese Military 'Comfort Women' System and Its Perception in History // The Annals of the American Academy of Political and Social Science. 2008. Vol.617. P. 123-132.

9. Japan Apologizes on Korea Sex Issue // The New York Times [Электронный pecypc]. URL: https://www.nytimes.com/1992/01/18/world/japan-apologizes-on-korea-sexissue.html (дата обращения: 10.11.2019).

10. Japan Pulls Diplomats From South Korea Over Comfort-Women Statue // The Wall Street Journal [Электронный pecypc]. URL: https://www.wsj.com/articles/japanpulls-diplomats-from-south-korea-over-comfort-women-statue-1483678744 (дата обращения: 12.11.2019).

11. Kazuko W. Militarism, colonialism, and the trafficking of women: "Comfort women" forced into sexual labor for Japanese soldiers // Bulletin of Concerned Asian Scholars. 1994. 26. No.4. P. 3-17.

12. Min P. Korean "Comfort Women": The Intersection of Colonial Power, Gender, and Class // Gender and Society. 2003. Vol. 17(6). P. 938-957.

13. Ryang S., Lie J. Diaspora without Homeland: Being Korean in Japan. Berkeley: University of California Press, 2009. 236 p.

14. Simone de Beauvoir and Second-Wave Feminism // ThoughtCo [Электронный pecypc]. URL: https://www.thoughtco.com/simone-de-beauvoir-and-second-wavefeminism-3530400 (дата обращения: 11.11.2019).

15. South Korea: New generation joins 'comfort women' fight // Aljazeera [Электронный pecypc]. URL: https:/www.aljazeera.com/indepth/features/2017/09/southkorea-generation-joins-comfort-women-fight-170918081137927.html (дата обращения: 14.11.2019).

16. South Korean president lashes Japan over wartime use of 'comfort women' // Reuters [Электронный pecypc]. URL: https://www.reuters.com/article/us-southkoreaindependenceday/south-korean-president-lashes-japan-over-wartime-use-of-comfortwomen-idUSKCN1GD3J1 (дата обращения: 13.11.2019).

17. Statue of 'comfort woman' erected outside Japanese Embassy in Seoul // The Japan Times [Электронный ресурc]. URL: https://www.japantimes.co.jp/news/2011/12/15/ 
national/statue-of-comfort-woman-erected-outside-japanese-embassy-in-seoul/\#. $\mathrm{XeR40OgzY2w} \mathrm{(дата} \mathrm{обращения:} \mathrm{11.11.2019).}$

18. Testimonies of the Victims // The Comfort Women Issue and the Asian Women's Fund [Электронный ресурc]. URL: http://www.awf.or.jp/e3/oralhistory-00.html (дата обращения: 10.11.2019).

19. Tsuchiya K. Reinventing Citizenship: Black Los Angeles, Korean Kawasaki, and Community Participation. University of Minnesota Press, 2014. 280 p.

20. 우리는 왜 삼포세대가 되어 가는가? (Почему наше общество превращается в "поколение сампо"?) // OhMyNews [Электронный ресурс]. URL: http://www. ohmynews.com/NWS_Web/View/at_pg.aspx?CNTN_CD=A0002128830 (дата обращения: 14.11.2019).

21. 한국 생존 위안부들 '일본 진실한 사과와 배상해야 한다.' (Женщины для утешения: "Япония должна искренне извиниться и выплатить компенсацию") // News in Progress [Электронный pecypc]. URL: https://thenewspro.org/2018/11/25/south-koreassurviving-comfort-women/ (дата обращения: 13.11.2019).

22. 한국정신대문제대책협의회 (Корейский совет по делам женщин, призванных к военному сексуальному рабству Японией) // 한국민족문화대백과 (Корейская национальная культурная энциклопедия) [Электронный ресурс]. URL: https://terms. naver.com/entry.nhn?docId=5144326\&cid=46624\&categoryId=46624 (дата обращения: 12.11.2019).

\section{Транслитерация по ГОСТ 7.79-2000 Система Б}

1. Vasil'eva T.A. Immigratsionnoe zakonodatel'stvo i migratsionnaya politika YAponii / T.A. Vasil'eva // Trudy Instituta gosudarstva i prava RAN. 2010. №3. S. 185-208.

2. Kurbanov S. O. Istoriya Korei s drevnosti do nachala XXI veka / S.O. Kurbanov. SPb.: Izd-vo S.-Peterb. un-ta, 2009. $680 \mathrm{~s}$.

3. Stantsii utesheniya dlya yaponskikh soldat // Voennoe obozrenie [Ehlektronnyj resurs]. URL: https://topwar.ru/136069-stancii-utesheniya-dlya-yaponskih-soldat.html (data obrashheniya 11.11.2019).

4. Bullock J., Kano A., Welker J. Rethinking Japanese Feminisms. Honolulu: University of Hawaii Press, 2018. 310 p.

5. Ching M. Minjung feminism: Korean women's movement for gender and class liberation // Women's Studies International Forum. 1995. Vol. 18(4). P. 417-430.

6. Chung E.A. Exercising Citizenship: Koreans Living in Japan // Asian Perspective. 2000. Vol. 24 (4). P. 159-178.

7. Hawon, J. The Special Permanent Residents in Japan: Zainichi Korean [Ehlektronnyj resurs]. URL: http://yris.yira.org/comments/2873 (data obrashheniya 10.11.2019).

8. Hayashi H. Disputes in Japan over the Japanese Military 'Comfort Women' System and Its Perception in History // The Annals of the American Academy of Political and Social Science. 2008. Vol.617. P. 123-132.

9. Japan Apologizes on Korea Sex Issue // The New York Times [Ehlektronnyj resurs]. URL: https://www.nytimes.com/1992/01/18/world/japan-apologizes-on-korea-sex-issue. html (data obrashheniya: 10.11.2019).

10. Japan Pulls Diplomats From South Korea Over Comfort-Women Statue // The Wall Street Journal [Ehlektronnyj resurs]. URL: https://www.wsj.com/articles/japanpulls-diplomats-from-south-korea-over-comfort-women-statue-1483678744 (data obrashheniya: 12.11.2019).

11. Kazuko W. Militarism, colonialism, and the trafficking of women: "Comfort women" forced into sexual labor for Japanese soldiers // Bulletin of Concerned Asian Scholars. 1994. 26. No.4. P. 3-17.

12. Min P. Korean "Comfort Women": The Intersection of Colonial Power, Gender, and Class // Gender and Society. 2003. Vol. 17(6). P. 938-957.

13. Ryang S., Lie J. Diaspora without Homeland: Being Korean in Japan. Berkeley: University of California Press, 2009. 236 p.

14. Simone de Beauvoir and Second-Wave Feminism // ThoughtCo [Ehlektronnyj resurs]. URL: https://www.thoughtco.com/simone-de-beauvoir-and-second-wave-feminism-3530400 (data obrashheniya: 11.11.2019).

15. South Korea: New generation joins 'comfort women' fight // Aljazeera [Ehlektronnyj resurs]. URL: https://www.aljazeera.com/indepth/features/2017/09/south-korea-generation-joins-comfort-women-fight-170918081137927.html (data obrashheniya: 14.11.2019).

16. South Korean president lashes Japan over wartime use of 'comfort women' i/ Reuters [Ehlektronnyj resurs]. URL: https://www.reuters.com/article/us-southkorea-independenceday/south-korean-president-lashes-japan-over-wartime-use-of-comfort-women-idUSKCN1GD3J1 (data obrashheniya: 13.11.2019).

17. Statue of 'comfort woman' erected outside Japanese Embassy in Seoul // The Japan Times [Ehlektronnyj resurs]. URL: https://www.japantimes.co.jp/news/2011/12/15/na- 
tional/statue-of-comfort-woman-erected-outside-japanese-embassy-in-seoul/\#.XeR40OgzY2w (data obrashheniya: 11.11.2019).

18. Testimonies of the Victims // The Comfort Women Issue and the Asian Women's Fund [Ehlektronnyj resurs]. URL: http://www.awf.or.jp/e3/oralhistory-00.html (data obrashheniya: 10.11.2019).

19. Tsuchiya K. Reinventing Citizenship: Black Los Angeles, Korean Kawasaki, and Community Participation. University of Minnesota Press, 2014. 280 p.

20. 우리는 왜 삼포세대가 되어 가는가? (Pochemu nashe obshhestvo prevrashhaetsya v "pokolenie sampo"?) // OhMyNews [Ehlektronnyj resurs]. URL: http://www. ohmynews.com/NWS_Web/View/at_pg.aspx?CNTN_CD=A0002128830 (data obrashheniya: 14.11.2019).

21. 한국 생존 위안부들 '일본 진실한 사과와 배상해야 한다.' (ZHenshhiny dlya utesheniya: "YAponiya dolzhna iskrenne izvinit'sya i vyplatit' kompensatsiyu") // News in Progress [Ehlektronnyj resurs]. URL: https://thenewspro.org/2018/11/25/south-koreas-surviving-comfort-women/ (data obrashheniya: 13.11.2019).

22. 한국정신대문제대책협의회 (Korejskij sovet po delam zhenshhin, prizvannykh $\mathrm{k}$ voennomu seksual'nomu rabstvu YAponiej) // 한국민족문화대백과 (Korejskaya natsional'naya kul'turnaya ehntsiklopediya) [Ehlektronnyj resurs]. URL: https://terms.naver.com/entry.nhn?docId $=5144326 \&$ cid $=46624 \&$ categoryId $=46624$ (data obrashheniya: 12.11.2019).

Литвинцева А. И. "Женщины для утешения" как часть феминистского движения корейской диаспоры в Японии.

Начиная с 1970-х гг., женщины начали создавать сообщества единомышленниц, в которых они обсуждали вопросы неравноправия. Одной из животрепещущих тем для обсуждения была проблема "женщин для утешения": кореянки требовали от Японии официальных извинений и выплаты компенсации. Эта проблема стала одной из причин более стремительного развития феминистского движения кореянок, и в данной статье нашей целью было показать, как развивалось феминистское движение кореянок в Японии в рамках проблемы "женщин для утешения". Кратко описано положение корейской диаспоры после окончания Второй мировой войны, рассмотрены основные организации по решению проблемы "женщин для утешения", а также охарактеризована нынешняя ситуация данной проблемы.

Ключевые слова: "женщины для утешения", "станиии утешения", корейская диаспора, фбелинистское движение, Япония, Республика Корея

Litvintseva A. I."Comfort women" as a part of the feminist movement of the Korean diaspora in Japan.

Since the 1970s women also began to create like-minded communities in which they discussed issues of inequality. One of the burning topics for discussion was the issue of "comfort women": Koreans demanded official apologies and compensation from Japan. This problem became one of the reasons for the more rapid development of the feminist movement of Koreans, and in this article we wanted to show how the feminist movement of Koreans developed in Japan in the framework of the "comfort women" problem. The situation of the Korean diaspora after the end of the World War II is briefly described, the main organizations for solving the problem of "women for comfort" are considered, and the current situation of this problem is characterized.

Key words: "comfort women", "comfort stations", the Korean diaspora, the feminist movement, Japan, the Republic of Korea

Для цитирования: Литвинцева А. И. "Женщины для утешения" как часть феминистского движения корейской диаспоры в Японии // Ойкумена. Регионоведческие исследования. 2020. № 1. C. 79-87. DOI: $10.24866 / 1998-6785 / 2020-1 / 79-87$

For citation: Litvintseva A. I. "Comfort women" as a part of the feminist movement of the Korean diaspora in Japan // Ojkumena. Regional researches. 2020. № 1. P. 79-87. DOI: $10.24866 / 1998-6785 / 2020-1 / 79-87$ 


\section{Региональная политика России на Дальнем Востоке: обзор актуальных исследований}

Уходящая корнями в XIX в. проблема развития Дальнего Востока приобрела в современной России особую актуальность. Разведанные и относительно легко извлекаемые месторождения углеводородов и цветных металлов, доходы от экспорта которых составляют не менее половины государственного бюджета, скоро будут исчерпаны, а новые потенциальные участки расположены на востоке страны. Кроме того, в 2010-е гг. резко ухудшились отношения с Европой, ранее основным экономическим партнёром России, поэтому т.н. "поворот на Восток" приобрёл как экономический, так и политико-дипломатический характер.

В данной статье мы производим краткий обзор исследований региональной политики России на Дальнем Востоке в 2010-е гг. (основных научных центров, авторов, публикаций), сосредотачиваясь на политологических аспектах этого предмета. По большей части, его исследуют представители экономической географии и пространственной экономики, которые не ставят напрямую политологические вопросы, однако многие их работы содержат значимые для политологии наблюдения и выводы, а их оценки территориальной политики России в целом весьма полезны для понимания дальневосточных процессов.

Проблема развития Дальнего Востока представляет существенный интерес не только для российских авторов, но и для иностранных учёных и правительств: для европейских и американских - поскольку политика санкций привела к углублению сотрудничества России со странами Восточной Азии, прежде всего с Китаем, а это вовсе не тот результат, который хотели получить западные правительства, для азиатских - поскольку поворот России на Восток влечёт за собой и новые возможности, и новые риски. Мы производим обзор публикаций на русском и английском языках. В немалом количестве они выходят и на языках Восточной Азии, но их оценку лучше оставить специалистам со знанием этих языков. Отметим лишь, что в Китае центром соответствующих исследований является Институт России, Восточной Европы и Центральной Азии Китайской академии общественных наук, в Японии - Центр славяно-евразийских исследований университета Хоккайдо, в Южной Коpeе - Корейский институт международной экономической политики, этой темой также углублённо занимается Сон Вон Ён, профрессор Инчхонского национального университета и член Президентского комитета Республики Корея по экономическому сотрудничеству на северном направлении.

Московская школа проводит обобщающие исследования пространственного развития и региональной политики России, в которых Дальний Восток выступает одним из кейсов. Наиболее активны в этой сфере специалисты Института системного анализа ФИЦ ИУ РАН. А. Н. Швецов подчёркивает лидирующую роль государственной власти в формировании и преобразовании социоэкономического пространства России, по крайней мере, в последние три столетия. Сегодня правительство России пытается восстановить жёсткое советское управление регионами, что мало соответствует современной ситуации [23]. По его мнению, региональная политика России, в особенности, дальневосточная, разрабатывается и реализуется, исходя в большей степени из

\section{(C) Козлов Л. E., 2020}

КОЗЛОВ Леонид Евгеньевич, канд. полит. наук, доцент кафедры международных отношений Дальневосточного федерального университета (2. Владивосток). E-mail: kozlov.le@dvfu.ru

Статья выполнена при фринансовой поддержке РФФИ, проект № 18-014-00012 "Влияние региональной политики на международную интеграцию периферийных территорий (на примере стран Северо-Восточной Азии)" 
экспортных интересов государственных корпораций и внешнеполитических амбиций правительства, чем из интересов устойчивого развития нации и из рекомендаций пространственной экономики и экономической географиии [24]. А. Н. Швецов весьма сдержанно оценивает особые экономические зоны как инструмент регионального развития и считает, что федеральные чиновники возлагают на них нереальные ожидания и что дальневосточные "территории опережающего развития" скорее будут чёрными дырами, высасывающими ресурсы региона размещения, чем точками роста [22].

В. Н. Лексин полагает, что все проблемы Дальнего Востока имеют не внутрирегиональное происхождение, но порождены общими постсоветскими проблемами России, её внешней, экономической и социальной политикой. В целом позитивно оценивая "поворот на Восток", он призывает к тому, чтобы развитие Дальнего Востока и Байкальского региона стало первым шагом в решении системных проблем территориального развития России, прежде всего, сощиально-экономической связности территории страны с севера на юг и с запада на восток. Одностороннее усиление внешнеэкономического потенциала Дальнего Востока лишь ускорит дезинтеграцию России [10].

О. В. Кузнецова разработала оригинальную концепцию фракторов развития регионов, согласно которой государственная политика и качество управления являются хотя и важными, но всё же не столь значимыми фракторами, как место региона в общей системе территориальной организации страны, тип освоения и уровень развития региона, экономико-географическое положение, природные условия и ресурсы, состав населения, структура расселения, уровень развития и особенности хозяйства [8]. По её мнению, Дальний Восток занял ключевое место в региональной политике центра в 2010-е гг., и эта политика, наряду с развитием инфраструктуры добычи и транспортировки углеводородов на Востоке России, усилила интерес иностранных инвесторов к региону. Впрочем, новые инструменты развития привлекают в регион российский капитал в заметно большей степени, чем иностранный. Основными препятствиями для последнего являются низкая ёмкость местного рынка и плохая инфраструктура [7].

Сотрудник географического фракультета Московского государственного университета Н. В. Зубаревич выделяет выравнивающий, стимулирующий и геополитический приоритеты региональной политики. По её оценке, в 1990е гг. Россия придерживалась выравнивающего приоритета, перераспределяя доходы от экспорта нефти и газа в условиях сверхцентрализованной системы управления. В 2000-е гг. возобладал геополитический приоритет, при котором основные усилия центра направлены на обеспечение безопасности и удержание территорий, имеющих международное значение (в случае России - Дальний Восток, Крым, Калининградская область, Северный Кавказ). Это самый затратный вид региональной политики, к тому же государственные инвестиции в инфраструктуру таких регионов не слишком побуждают частных инвесторов приходить туда. Главным иностранным источником инвестиций для Дальнего Востока после 2014 г. стал Китай, который, возможно, будет более жёстко диктовать свои правила игры, потому что инвестиционные альтернативы России резко сузились [31].

В Государственном университете - Высшей школе экономики о развитии Дальнего Востока размышляет группа исследователей под руководством С. А. Караганова. Связанные с С. А. Карагановым Совет по внешней и оборонной политики и Международный дискуссионный клуб "Валдай" тоже включают дальневосточный вопрос в свою повестку, впрочем, они скорее ориентированы на разработку новой государственной стратегии и идеологии, чем на теоретические изыскания. По мнению сотрудника ГУ-ВШЭ И. А. Макарова, в связи с быстрым экономическим ростом азиатских стран у Дальнего Востока появились новые возможности, но нужна новая система управления регионом, чтобы их реализовать. В подходе центра к развитию Дальнего Востока произошёл решительный сдвиг от политики безопасности к поиску возможностей. При этом многочисленные проблемы региона сохраняются и решаются не слишком быстро, а лоббизм и сиюминутные политические выгоды зачастую влияют на дальневосточную политику России в ущерб долгосрочным национальным интересам [14]. 
В центре внимания Института экономики и организации промышленного производства СО РАН в Новосибирске находится развитие Сибири, но нередко ему требуется рассматривать сибирские сюжеты в увязке с дальневосточными. Наиболее предметно на эту тему в ИЭОПП высказывается В. Е. Селиверстов. Он замечает, что центр оказывает Дальнему Востоку существенно больше внимания, чем Сибири, хотя экономика Сибири намного превышает дальневосточную по объёму. По его мнению, ориентация Дальнего Востока сугубо на рынки АТР не соответствует национальным интересам России: следует формировать на территории Сибири и Дальнего Востока единое экономическое пространство, работающее, в первую очередь, на общероссийский рынок. Основной риск текущей политики центра состоит в усилении зависимости региона от Китая и закреплении сырьевого характера российского экспорта в Китай. Региональная политика в Сибири и на Дальнем Востоке разрабатывается в интересах крупного бизнеса, в ней практически отсутствуют меры по повышению социальной привлекательности этого макрорегиона [19].

В Институте экономических исследований ДВО РАН в Хабаровске первостепенное значение для понимания дальневосточной политики России имеют труды П. А. Минакира, который отмечает преемственность и историзм этой политики, предлагает её периодизацию, обобщает её традиционные проблемы и подходы. В соавторстве с О. М. Прокапало он показывает, что наилучших результатов Дальний Восток достигал в те периоды, когда государство совмещало внеэкономические цели и использование централизованных ресурсов с целями эндогенного воспроизводства в самом регионе, а наименее удачными были периоды, когда государство преследовало сугубо колониальную цель извлечения максимальной прибыли. Сегодня центр, продолжая эксплуатировать транзитные мощности и природные ресурсы Дальнего Востока, пытается воссоздать здесь диверсифицированную экономику [12]. П. А. Минакир также касается вопросов идеологии и общественного восприятия дальневосточной политики России. Сопровождавшая эту политику в 2014-2018 гг. массированная пропагандистская кампания сформировала устойчивые ожидания быстрых и положительных перемен в экономике и в социальной сфрере среди широких слоёв населения и бизнесменов. Этих изменений не произошло, что сильно разочаровало местное общество и, среди прочего, привело к протестному голосованию на губернаторских выборах [11].

Другой сотрудник ИЭИ ДВО РАН Д. А. Изотов доказывает, что стратегические решения правительства по Дальнему Востоку в 2010-е гг. повторяют широко известные специфичные меры зарубежных стран, подобных России, с высокой долей природной ренты в экономике, в частности, масштабные инвестиции в инфраструктуру, создание территорий с особым экономическим статусом, привлечение и закрепление населения. Более успешные экономики от подобных мер уже отказались [5].

В. К. Заусаев из ДальНИИ рынка (ныне Восточный центр государственного планирования) считает, что в условиях свободного рынка экономика Дальнего Востока стремится к концессионному и вахтовому сценарию развития, что порождает значительные проблемы для национальной безопасности, в том числе сокращение населения и усиление сырьевой специализации на фоне быстро развивающегося Китая. Если центр будет пытаться перераспределять доходы сырьевых компаний в перерабатывающие производства, это не найдёт понимания у крупных иностранных компаний. В. К. Заусаев настаивает, что Дальний Восток не является обузой для страны. Хотя регион требует значительных государственных инвестиций на инфраструктурное обустройство, высокоэффрективные добывающие проекты, типа "Сахалин-1" и "Сахалин-2", могут обеспечить не только его текущее существование, но и инвестиции в обрабатывающий сектор [4].

Во Владивостоке проводится много исследований по региональной политике России, которые, правда, носят разрозненный характер. Одним из центров этих исследований является Институт истории, археологии и этнографии народов Дальнего Востока ДВО РАН. В коллективной монографии под ред. В. Л. Ларина "Тихоокеанская Россия в интеграционном пространстве Северной Пацифики в начале XXI века" выделяются геополитические, экономические, военно-стратегические и идеологические основания активной политики центра по развитию Дальнего Востока. По мнению авторов, в 1990-е гг. пра- 
вительство России пожертвовало отношениями с Азией и развитием Дальнего Востока по причине европоцентризма и скудости бюджета, но как только оно получило достаточные фринансовые средства и рычаги влияния на регионы, Дальний Восток вошёл в число территориальных приоритетов. В течение тридцати лет, начиная с Долговременной программы 1987 г., политика развития Дальнего Востока была малоэффективной, но к этому следует относиться с пониманием, ведь системный масштаб проблем макрорегиона требует многолетнего воздействия, а не кампанейских методов и сверхконцентрации ресурсов [20].

А. Е. Савченко изучает развитие Дальнего Востока сквозь призму геополитической теории Р. Коллинза и теории инфраструктурной власти М. Манна. Сравнивая внутренние и международные фракторы развития региона, периоды программно-целевой политики и периоды опоры на частный капитал, он приходит к выводу, что Дальний Восток является классическим примером геополитического перенапряжения империи и с трудом будет поддаваться любому стимулирующему воздействию центра [15]. Также он указывает на схожесть Дальнего Востока России и Северо-Востока Бразилии как объектов региональной политики [16].

С. К. Песцов и А. Б. Волынчук на примере дальневосточной политики России делают выводы об общем содержании, основных подходах и принципах российской региональной политики. По их мнению, в настоящее время эта политика использует архаические меры вековой давности и более поздние, но тоже теряющие свою актуальность методы. Центр не прислушивается к рекомендациям т.н. подхода, основанного на возможностях мест (place-based approach), популярного в развитых странах, и эволюционирует по пути, отличном от общемировых трендов, что консервирует на неопределённое время положение Дальнего Востока как слабоосвоенной периферийной территории [13].

Сотрудники Дальневосточного федерального университета в своих исследованиях пользуются таким преимуществом, как возможность посещать Восточный әкономический форум и многие другие публичные мероприятия по теме регионального развития, проводимые в университетских стенах, где они сами часто выступают в качестве экспертов. С. В. Севастьянов полагает, что инфраструктура саммита АТЭС-2012 позволила Владивостоку стать одним из значимых центров международного сотрудничества и окном России в АТР. Саммит продемонстрировал понимание руководством России масштаба дальневосточных проблем и готовность к их решению. Непринятие действенных мер по развитию региона делает реальным геополитический риск его экономического отторжения более успешными соседями [17]. Также С. В. Севастьянов в соавторстве с А. А. Кравчуком доказывает необходимость согласованного развития Дальнего Востока и Арктики, анализируя сопряжение проектов по добыче в Арктике углеводородов и их обработке на юге Дальнего Востока, расширение мощности Северного морского пути и увязанного с ним судостроения в Приморском крае, подготовку кадров для арктических проектов в ДВФУ [18].

Центральной проблемой монографии А. Л. Лукина и его американского соавтора Р. Ли "Дальний Восток России. Новая динамика в АТР и за его пределами" является растущее экономическое и политическое влияние Китая на Россию в целом и Дальний Восток в частности. В монографии рассматриваются исторические тенденции освоения Дальнего Востока, текущая экономическая и политическая динамика, место региона среди приоритетов территориального развития России, специфика внешних связей региона, влияние украинского кризиса и западных санкций на траекторию развития Дальнего Востока и на баланс международных отношений в Северо-Восточной Азии. Авторы рекомендуют правительству США преодолевать разногласия с Россией и подключиться к развитию Дальнего Востока, пока экономика России не стала чересчур зависимой от Китая [27].

А. А. Киреев изучает политику Москвы в отношении Дальнего Востока в аспекте государственного регулирования трансграничных связей региона: миграционных, внешнеторговых и инвестиционных. По его мнению, пограничная политика центра в очень ограниченной степени стимулирует разви- 
тие Дальнего Востока. Главным её изъяном автор называет устойчивое преобладание приоритета безопасности над целями развития региона [6].

Автор данного обзора сосредотачивается на изучении взаимосвязи международных отношений России со странами CBA и региональной политики России на Дальнем Востоке. По нашему мнению, в региональной политике России социально-экономические задачи, задачи внутренней стабильности и безопасности и рентоориентированное поведение чиновников образуют единый конгломерат фракторов, который далеко не полностью представлен в публичных документах и заявлениях политиков. Делая поправку на дихотомию декларативной и реальной региональной политики, не следует излишне критиковать последнюю за неэффективность: экспортные задачи сырьевых корпораций она решает довольно успешно, а управляемость Дальнего Востока посредством сочетания стимулирующих, рестриктивных и репрессивных мер поддерживается [26].

В Тихоокеанском институте географии ДВО РАН П. Я. Бакланов исследует геополитические фоккторы развития Дальнего Востока. Он считает, что уникальные возможности этому макрорегиону даёт его геополитическое положение, в том числе широкий выход к морям, выход к самым влиятельным странам мира (КНР, США, Японии), многоуровневая трансграничность. Впрочем, многие структурные звенья территориальных социально-экономических систем Дальнего Востока отличаются большой инерцией, что затрудняет управление их развитием [2].

Другой сотрудник ТИГ ДВО РАН Ю.А. Авдеев специализируется на демографических аспектах развития Дальнего Востока. По его мнению, многочисленные меры центра по преодолению негативных демографических тенденций пока малоэффрективны. В северных районах Дальнего Востока вахтовый метод является неизбежным следствием рыночной экономики, но в южных районах внешняя миграция вполне может стать драйвером устойчивого развития. В 2010-е гг. Дальний Восток, по не зависящим от российских властей рыночным причинам, значительно потерял в привлекательности для мигрантов из Северо-Восточной и Центральной Азии, поэтому сегодня здесь требуется более либеральный миграционный режим, чем это предусмотрено федеральным законодательством, чтобы остановить сокращение постоянного населения [1].

Во Владивостокском государственном университете экономики и сервиса особый интерес представляют публикации А. П. Латкина. Задолго до эксцессов на дальневосточных выборах 2018 г. он указал на то, что эфрфективное политическое управление Дальним Востоком требует существенного улучшения качества жизни, включая сравнительную стоимость питания, социально-бытового и коммунального обслуживания, здравоохранения и образования. Продолжающийся отток дальневосточников в Центральную Россию закономерен и свидетельствует о низкой результативности региональной политики центра [9].

В 2016 г. в ДВФУ защитил диссертацию по региональной политике России сотрудник Северо-Восточного фредерального университета (Якутск) Н. А. Григорьев. Согласно его выводам, на Дальнем Востоке закрепилась корпоративная модель взаимодействия региональных и муниципальных органов власти с фринансово-промышленными группами, в которой первые имеют мало возможностей влиять на реализацию корпоративных инвестиционных проектов и на деятельность "территорий опережающего развития". В Якутии в рамках этой системы задачи создания крупных промышленно-энергетических районов решались в 2010-е гг. небезуспешно, однако республиканский бюджет всё равно остался дотационным. Одной из оригинальных и, на наш взгляд, справедливых рекомендаций автора по развитию Дальнего Востока является поддержка политической конкуренции на региональных выборах, содействие диверсификации региональных политических сил, что, правда, не укладывается в логику сверхцентрализованной региональной политики России последнего десятилетия [3].

Азиатские и европейские авторы опубликовали за последнее десятилетие несколько больших трудов, основанных на хорошем знании дальневосточной эмпирики. Как правило, в этом деле они сотрудничают с учеными из Владивостока или Хабаровска. Обзор более ранней англоязычной (преимуще- 
ственно, американской) литературы представлен в статье Е. Н. Чернолуцкой [21].

В норвежской монографии "Поворот России на Восток", среди соавторов которой присутствует ещё один специалист ДВФУ Т. Г. Троякова, Дальний Восток рассматривается в контексте генерального стремления России к экономическому развитию и безопасности. Главный вывод работы состоит в том, что ключевые политические инициативы, направленные на развитие региона, были сформулированы задолго до кризиса в отношениях России и Запада, равно как и задолго до этого началось сближение России и Китая. Некоторые дипломатические успехи в "повороте на Восток" были достигнуты, однако в посткрымский период инвестиции России в развитие Дальнего Востока неуклонно сокращались и не имели большого успеха, так что говорить об уходе России из Европы в Азию пока рано. Главный редактор монографии Х. Блаккисруд указывает на то, что подход Москвы к управлению Дальним Востоком и к переориентации России на отношения со странами Восточной Азии базируется на традиционных принципах постсоветской бюрократии, а именно: государство является лидером в модернизации и экономическом развитии, реформы должны идти по некоему стратегическому плану, желательно в форме целевых программ. В то же время такой этатизм часто сосуществует с ручным управлением, когда высшие должностные лица страны вынуждены участвовать в решении частных региональных проблем [29].

Монография "Политэкономия Тихоокеанской России" подготовлена сотрудниками Национального университета Сингапура с привлечением әкспертов из России, Китая, Южной Кореи, Японии, Норвегии. Авторы исследуют геоэкономическое и геополитическое положение "Тихоокеанской России", а также анализируют основные фракторы развития региона и механизмы, которые позволяют интегрировать его в Азию. Они утверждают, что такое развитие имеет большое значение для диверсификации российской экономики, но этот поворот в Азию далеко не завершён. Рассматривая роль международного сотрудничества в развитии Дальнего Востока и Сибири, они приходят к выводу, что Россия выиграет от того, что "поворот на Восток" будет действительно международным и многосторонним. В любом случае, интеграция России в ATP началась, а кризис в отношениях между Россией и Западом лишь придал ей ускорение [30].

С. Малле (университет Вероны) и Дж. Купер (университет Бирмингема), анализируя смещение вектора территориального развития России на восток, приходят к выводу, что ускоренное развитие Дальнего Востока - это ответ России на возвышение Китая. Они указывают на то, что укрепление обороны и развитие Востока России стали главными приоритетами правления Путина. Авторы отмечают доминирование государства в территориальном развитии России и не отрицают, что оно может достигать положительных результатов, но считают, что это весьма затратная стратегия, а больший эффрект дали бы равноправный диалог центра с региональными администрациями и бизнесом и расширение полномочий регионов в выборе и поддержке льготами проектов развития [28].

Я. Адда (университет Женевы), собравший на Дальнем Востоке большой массив социологических материалов, доказывает, что в 1990-2000-е гг. Москва была неспособна разработать эфффективную политику на Дальнем Востоке и вызвала много разочарований у местного населения. Однако в течение ближайших десятилетий этот регион останется стратегическим приоритетом для Москвы. Опираясь на теорию хартленда, он делает вывод о том, что Россия будет постепенно переходить из состояния европейской державы, имеющей владения в Азии, в принщипиально иное геополитическое состояние, связанное с изменением менталитета россиян, социально-экономической политики центра и его дипломатических стратегий [25].

Представленный обзор позволяет сделать несколько выводов. Во-первых, принципиальная активизация внешней и региональной политики России на восточном направлении не подвергается сомнению как в отечественной, так и в зарубежной литературе. Во-вторых, эфрфективность региональной политики России на Дальнем Востоке почти все авторы оценивают более или менее критично. Многие указывают на то, что на практике она, главным образом, отражает интересы крупного российского бизнеса, а развитие такой слож- 
ной и инерционной социально-экономической системы, как регион, находится на переднем плане лишь в декларативных и программных государственных документах. В-третьих, большинство представленных авторов не занимается дальневосточной политикой России в качестве основной своей темы или не является политологами. Существует явный дефицит долгосрочных политических исследований, имеющих целью установление новых закономерностей и выработку новых научных законов на базе дальневосточной эмпирики, проведение межстрановых сравнений, построение работающих в различных государствах и исторических периодах моделей.

\section{Литература}

1. Авдеев Ю. А. О демографической политике для российского Дальнего Востока // Статистика и Экономика. 2017. № 6. С. 59-68.

2. Бакланов П.Я. Тихоокеанская Россия: географические и геополитические факторы развития // Известия РАН. Серия географическая. 2015. № 5. С. 8-19.

3. Григорьев Н. А. Государственная региональная политика на Дальнем Востоке в системе отношений "центр-регион": дисс. ... канд. пол. наук: 23.00.02. Якутск, 2015. 157 c.

4. Заусаев В. К. Дальний Восток России: бросок в глобализацию или государственный патернализм? // ЭКО. 2014. № 3. С. 105-114.

5. Изотов Д. А. Ускорение экономики Дальнего Востока: помогут ли новые институты? // Журнал новой экономической ассоциации. 2018. № 2. С. 155-163.

6. Киреев А. А. Пограничная политика России на Дальнем Востоке: динамика задач и результатов // Проблемы Дальнего Востока. 2017. № 3. С. 95-108.

7. Кузнецова О. В. "Восточный вектор" инвестиционных связей России // Мировая экономика и международные отношения. 2018. Т. 62, № 2. С. 47-56.

8. Кузнецова О. В. Региональная политика России: 20 лет реформ и новые возможности. M.: URSS, 2013. 392 с.

9. Латкин А. П. Сравнительная стоимость жизни как ключевой фрактор развития российского Дальнего Востока // Территория новых возможностей. Вестник ВГУ ЭС. 2017. Т. 9, № 3. С. 47-56.

10. Лексин В. Н. Региональная политика России и ее "восточный вектор" // Проблемный анализ и государственно-управленческое проектирование. 2014. Т. 7. № 4. C. $33-48$.

11. Минакир П. А. Дальневосточные институциональные новации: имитация нового этапа // Пространственная экономика. 2019. Т. 15, № 1. С. 7-17.

12. Минакир П. А., Прокапало О. М. Централизация и автономизация как фракторы социально-экономического развития Дальнего Востока России // Экономические и социальные перемены: факты, тенденции, прогноз. 2017. Т. 10, № 6. С. 24-41.

13. Песцов С. К., Волынчук А. Б. Стратегия развития Дальнего Востока: (не)типичный случай современной российской региональной политики // Историческая и социально-образовательная мысль. 2018. Т. 10, № 3-1. С. 82-92.

14. Поворот на Восток: Развитие Сибири и Дальнего Востока в условиях усиления азиатского вектора внешней политики России / Отв. ред. И. А. Макаров. М.: Международные отношения, 2015. $447 \mathrm{c}$.

15. Савченко А. Е. Дальний Востокконца XX - начала XXI в. как "зеркало"системных проблем российского государства // Россия и АТР. 2017. № 4. С. 8-30.

16. Савченко А. Е. Региональная политика в России и Бразилии как поле для сравнительного исследования // Труды Института истории, археологии и этнографии ДВО РАН. 2019. Т. 22. С. 147-158.

17. Севастьянов С. В. Проблемы и перспективы развития Дальнего Востока России после Владивостокского саммита АТЭС // Ойкумена. Регионоведческие исследования. 2013. № 1. С. 7-16.

18. Севастьянов С. В., Кравчук А. А. Ускоренное развитие Арктики и Дальнего Востока: синергия проектов // Ойкумена. Регионоведческие исследования. 2019. № 4. C. $7-21$.

19. Селиверстов В. Е. Три вектора пространственной конфигурации Сибири и Дальнего Востока и роль Китая на востоке России // Проблемный анализ и государственно-управленческое проектирование. 2014. Т. 7, № 4. С. 49-64.

20. Тихоокеанская Россия в интеграционном пространстве Северной Пацифики в начале XXI века: опыт и потенциал регионального и приграничного взаимодействия / под ред. В. Л. Ларина. Владивосток: ИИАЭ ДВО РАН, 2017. 386 с.

21. Чернолуцкая Е. Н. Англоязычная историография о политических трансформациях на Дальнем Востоке России в 1990 - начале 2000-х гг. // Историческая и социально-образовательная мысль. 2018. Т. 10, № 3-1. С. 114-123. 
22. Швецов А. Н. Инструменты политики поляризованного пространственного развития // Федерализм. 2018. № 1. С. 82-103.

23. Швецов А. Н. Роль государства в преобразовании социоэкономического пространства // Пространственная экономика. 2015. № 1. С. 38-61.

24. Швецов А. Н. Совершенствование региональной политики: концепции и практика. М.: КРАСАНД, 2010. 320 с.

25. Adda, Iacopo. L'Extreme-Orient russe: un acteur central dans le glissement de la Federation de Russie a l'Est / Global Studies Institute de L'Universite de Geneve. Collection Euryopa. Vol. 84. Geneve, 2015. 143 p.

26. Kozlov L., Volynchuk A. Dichotomy of Declarative and Real Regional Politics in Modern Russia // Journal of Politics and Law. 2019. Vol. 12, No. 5. P. 118-128.

27. Lee R., Lukin A. Russia's Far East. New Dynamics in Asia Pacific and Beyond. Boulder; London: Lynne Rienner Publishers, 2016. 276 pp.

28. Malle S., Cooper J. The pendulum moves from Europe to Asia. Modernizing Siberia and the Far East. Economic and security issues // Journal of Eurasian Studies. 2014. No. 5. P. 21-38.

29. Russia's Turn to the East. Domestic Policymaking and Regional Cooperation. Eds. H. Blakkisrud, E. Wilson Rowe. London: Palgrave Pivot, 2018. 167 p.

30. The Political Economy of Pacific Russia. Regional Developments in East Asia. Eds. Jing Huang, A. Korolev. Cham: Palgrave Macmillan, 2017. 268 p.

31. Zubarevich N. Geopolitical Priorities in Russia's Regional Policies. Opportunities and Risks // Russian Politics \& Law. 2015. Vol. 53, Issue 5-6. P. 44-62.

\section{Транслитерация по ГОСТ 7.79-2000 система Б}

1. Avdeev Yu. A. O demograficheskoj politike dlya rossijskogo Dal'nego Vostoka // Statistika i Ehkonomika. 2017. № 6. S. 59-68.

2. Baklanov P. Ya. Tikhookeanskaya Rossiya: geograficheskie i geopoliticheskie faktory razvitiya // Izvestiya RAN. Seriya geograficheskaya. 2015. № 5. S. 8-19.

3. Grigor'ev N. A. Gosudarstvennaya regional'naya politika na Dal'nem Vostoke v sisteme otnoshenij "tsentr-region": diss. ... kand. pol. nauk: 23.00.02. YAkutsk, 2015. $157 \mathrm{~s}$.

4. Zausaev V. K. Dal'nij Vostok Rossii: brosok v globalizatsiyu ili gosudarstvennyj paternalizm? // EHKO. 2014. № 3. S. 105-114.

5. Izotov D. A. Uskorenie ehkonomiki Dal'nego Vostoka: pomogut li novye instituty? // ZHurnal novoj ehkonomicheskoj assotsiatsii. 2018. № 2. S. 155-163.

6. Kireev A. A. Pogranichnaya politika Rossii na Dal'nem Vostoke: dinamika zadach i rezul'tatov // Problemy Dal'nego Vostoka. 2017. № 3. S. 95-108.

7. Kuznetsova O. V. "Vostochnyj vektor" investitsionnykh svyazej Rossii // Mirovaya ehkonomika i mezhdunarodnye otnosheniya. 2018. T. 62, № 2. S. 47-56.

8. Kuznetsova O. V. Regional'naya politika Rossii: 20 let reform i novye vozmozhnosti. M.: URSS, 2013. $392 \mathrm{~s}$.

9. Latkin A. P. Sravnitel'naya stoimost' zhizni kak klyuchevoj faktor razvitiya rossijskogo Dal'nego Vostoka // Territoriya novykh vozmozhnostej. Vestnik VGUEHS. 2017. T. 9, № 3. S. 47-56.

10. Leksin V. N. Regional'naya politika Rossii i ee "vostochnyj vektor" // Problemnyj analiz i gosudarstvenno-upravlencheskoe proektirovanie. 2014. T. 7. № 4. S. 33-48.

11. Minakir P. A. Dal'nevostochnye institutsional'nye novatsii: imitatsiya novogo ehtapa // Prostranstvennaya ehkonomika. 2019. T. 15, № 1. S. 7-17.

12. Minakir P. A., Prokapalo O. M. TSentralizatsiya i avtonomizatsiya kak faktory sotsial'no-ehkonomicheskogo razvitiya Dal'nego Vostoka Rossii // Ehkonomicheskie i sotsial'nye peremeny: fakty, tendentsii, prognoz. 2017. T. 10, № 6. S. 24-41.

13. Pestsov S. K., Volynchuk A. B. Strategiya razvitiya Dal'nego Vostoka: (ne)tipichnyj sluchaj sovremennoj rossijskoj regional'noj politiki // Istoricheskaya i sotsial'no-obrazovatel'naya mysl'. 2018. T. 10, № 3-1. S. 82-92.

14. Povorot na Vostok: Razvitie Sibiri i Dal'nego Vostoka v usloviyakh usileniya aziatskogo vektora vneshnej politiki Rossii / Otv. red. I. A. Makarov. M.: Mezhdunarodnye otnosheniya, 2015. $447 \mathrm{~s}$.

15. Savchenko A. E. Dal'nij Vostok kontsa XX - nachala XXI v. kak "zerkalo" sistemnykh problem rossijskogo gosudarstva // Rossiya i ATR. 2017. № 4. S. 8-30.

16. Savchenko A. E. Regional'naya politika v Rossii i Brazilii kak pole dlya sravnitel'nogo issledovaniya // Trudy Instituta istorii, arkheologii i ehtnografii DVO RAN. 2019. T. 22. S. 147-158.

17. Sevast'yanov S. V. Problemy i perspektivy razvitiya Dal'nego Vostoka Rossii posle Vladivostokskogo sammita ATEHS // Ojkumena. Regionovedcheskie issledovaniya. 2013. № 1. S. 7-16.

18. Sevast'yanov S. V., Kravchuk A. A. Uskorennoe razvitie Arktiki i Dal'nego Vostoka: sinergiya proektov // Ojkumena. Regionovedcheskie issledovaniya. 2019. № 4. S. 7-21. 
19. Seliverstov V. E. Tri vektora prostranstvennoj konfiguratsii Sibiri i Dal'nego Vostoka i rol' Kitaya na vostoke Rossii // Problemnyj analiz i gosudarstvenno-upravlencheskoe proektirovanie. 2014. T. 7, № 4. S. 49-64.

20. Tikhookeanskaya Rossiya v integratsionnom prostranstve Severnoj Patsifiki v nachale XXI veka: opyt i potentsial regional'nogo i prigranichnogo vzaimodejstviya / pod red. V. L. Larina. Vladivostok: IIAEH DVO RAN, 2017. 386 s.

21. Chernolutskaya E. N. Angloyazychnaya istoriografiya o politicheskikh transformatsiyakh na Dal'nem Vostoke Rossii v 1990 - nachale 2000-kh gg. // Istoricheskaya i sotsial'no-obrazovatel'naya mysl'. 2018. T. 10, № 3-1. S. 114-123.

22. Shvetsov A. N. Instrumenty politiki polyarizovannogo prostranstvennogo razvitiya // Federalizm. 2018. № 1. S. 82-103.

23. Shvetsov A. N. Rol' gosudarstva v preobrazovanii sotsioehkonomicheskogo prostranstva // Prostranstvennaya ehkonomika. 2015. № 1. S. 38-61.

24. Shvetsov A. N. Sovershenstvovanie regional'noj politiki: kontseptsii i praktika. M.: KRASAND, 2010. $320 \mathrm{~s}$.

25. Adda, Iacopo. L'Extreme-Orient russe: un acteur central dans le glissement de la Federation de Russie a l'Est / Global Studies Institute de L'Universite de Geneve. Collection Euryopa. Vol. 84. Geneve, 2015. 143 p.

26. Kozlov L., Volynchuk A. Dichotomy of Declarative and Real Regional Politics in Modern Russia // Journal of Politics and Law. 2019. Vol. 12, No. 5. P. 118-128.

27. Lee R., Lukin A. Russia's Far East. New Dynamics in Asia Pacific and Beyond. Boulder; London: Lynne Rienner Publishers, 2016. 276 pp.

28. Malle S., Cooper J. The pendulum moves from Europe to Asia. Modernizing Siberia and the Far East. Economic and security issues // Journal of Eurasian Studies. 2014. No. 5. P. 21-38.

29. Russia's Turn to the East. Domestic Policymaking and Regional Cooperation. Eds. H. Blakkisrud, E. Wilson Rowe. London: Palgrave Pivot, 2018. 167 p.

30. The Political Economy of Pacific Russia. Regional Developments in East Asia. Eds. Jing Huang, A. Korolev. Cham: Palgrave Macmillan, 2017. 268 p.

31. Zubarevich N. Geopolitical Priorities in Russia's Regional Policies. Opportunities and Risks // Russian Politics \& Law. 2015. Vol. 53, Issue 5-6. P. 44-62. 
Козлов Л. Е. Региональная политика России на Дальнем Востоке: обзор актуальных исследований.

В статье производится обзор публикаций на русском и английском языках последнего десятилетия, в основном политологов, но также и специалистов по экономической географии и пространственной экономике, которые содержат значимые для политологии наблюдения и выводы. Принципиальная активизация внешней и региональной политики России на восточном направлении не подвергается сомнению в научной литературе, при этом эффективность данной политики все авторы оценивают более или менее критично. Существует дефицит долгосрочных политических исследований, имеющих целью выработку новых законов на основе дальневосточной эмпирики, проведение межстрановых сравнений, построение работающих в различных условиях моделей.

Ключевые слова: региональная политика, пространственное развитие, Российский Дальний Восток, региональные исследования

Kozlov L. E. Regional policy of Russia in the Far East: an overview of current research.

Our review covers publications in Russian and English of the last decade, mainly in the field of political science, but also of economic geography and spatial economics, which contain observations and conclusions that are significant for political science. The fundamental eastward shift of Russia's foreign and regional policies is not questioned in the academic literature, and all authors evaluate the effectiveness of this policy more or less critically. There is a shortage of long-term political research that would aim to develop new laws based on Far Eastern empiricism, make cross-country comparisons, and build models that work under different conditions.

Key words: regional policy, spatial development, Russian Far East, regional studies

Для цитирования: Козлов Л. Е. Региональная политика России на Дальнем Востоке: обзор актуальных исследований // Ойкумена. Регионоведческие исследования. 2020. № 1. C. 88-97. DOI: $10.24866 / 1998-6785 / 2020-1 / 88-97$

For citation: Kozlov L. E. Regional policy of Russia in the Far East: an overview of current research // Ojkumena. Regional researches. 2020. № 1. P. 88-97. DOI: 10.24866/1998-6785/20201/88-97 


\section{Взаимное влияние процессов формирования гражданской культуры и социально-политического муниципального пространства: от Приамурского Земского собора до настоящего времени}

Одной из очевидных социально-политических проблем современной российской государственности является проблема неэффрективного местного самоуправления. Традищионно местное самоуправление является индикатором качества государственного управления в болышинстве развитых стран. Ориентируя в социальном пространстве государственные институты на человека и персонифицируя конечного получателя материальных и нематериальных благ, обозначенных или гарантированных государством, местное самоуправление обеспечивает реализацию основной конституционной нормы, определяющей Российскую Федерацию сощиальным государством.

Постоянные попытки реформировать те или иные аспекты муниципальной системы управления определены самой низкой электоральной активностью населения при формировании органов местного самоуправления, неэфрфективным использованием ресурсного обеспечения муниципалитетов и общей социальной неудовлетворённостью граждан. Все эти обстоятельства предопределяют необходимость нахождения сложных точек в поселенческих демократиях, требуют изучения, обобщения и выделения положительного исторического опыта в данной сфере общественных отношений, апробации и внедрения новых или хорошо забытых инструментов территориальной или организационной институционализации базового уровня системы государственного управления.

В структуралистском конструктивизме П. Бурдье пространство выступает как поле и проявляется в отношениях между позициями, "необходимость которых навязывается агентам" [3]. Иными словами, социально-политическое пространство определяется социальными отношениями акторов. Размещение и близость агентов по отношению друг к другу в сощиально-политическом пространстве зависят от наличия у них общих свойств. Более того, чем больше свойств, тем ближе агенты и наоборот. Габитус, по мнению П. Бурдье, включает в себя свойства, которые отражают опыт и знания актора [4], это его культура.

Гражданская, правовая, коммунально-бытовая, корпоративная и другие элементы культуры, весь совокупный многовековой социально-политический опыт участия индивида и социальных групп разного формата в инициации, в последующей координации общественных процессов являются основой социальной гармонии. Как отмечает Э. Баталов, гражданская культура - это даже не смесь, а именно баланс разных культур, своего рода американская система "сдержек и противовесов", перенесённая из сферы властных отношений в сфреру политической культуры [2].

Формирующаяся на фоне государства гражданская культура является основным фактором состояния государственной политики на всех её уровнях. В рамках деятельностного подхода в исследованиях гражданской культуры М. В. Савва полагает, что "гражданская культура - это система установок че-

(C) Булах Е. В., Князева А. Р., Цой В. Г., 2020

БУЛАХ Евгений Васильевич, канд. полит. наук, доцент, доцент кафедры политологии Дальневосточного федерального университета (2. Владивосток). E-mail: bulakhevg@mail.ru

КНЯЗЕВА Анастасия Романовна, студент (бакалавр), кафедры политологии Дальневосточного федерального университета (2. Владивосток). E-mail: nastya.kn.r@bk.ru

ЦОЙ Владислава Геннадьевна, студент (бакалавр) кафедры политологии Дальневосточного федерального университета (2. Владивосток). E-mail: v.tsoy.98@mail.ru 
ловека на его взаимодействие с властью и другими гражданами в решении общих проблем и тип поведения в таком взаимодействии" [11]. Социальная функция государства определила социальные компоненты основными мотиваторами общественных процессов, чем обеспечила накопление социального опыта. Функция гаранта и стабилизационная фрункция выделили совокупность политико-правовых инструментов и механизмов, что способствует накоплению опыта политического участия. Социальная составляющая указывает на субъектные фракторы формирования гражданской культуры, политико-правовая составляющая - на фракторы рационально-прагматичного характера. Подобное представление позволяет выделить основы гражданской культуры:

- рационально-прагматичная основа;

จ эмоционально-харизматичная основа.

Такое основополагание в представлении гражданской культуры - это некий баланс между инструментальной и эмоциональной ориентацией на общественные процессы. Оно является подтверждением взаимовлияния прагматичной публичной политики и эмоционального индивидуализма, поэтому политика не должна быть настолько прагматичной, чтобы участники теряли всякую эмоциональную вовлеченность в неё. При этом уровень эмоционального отношения к политической жизни не должен становиться слишком высоким [1, с. 466-467].

Подобное сдержанное состояние коллективного сознания - залог стабильности политической системы. Это позволяет утверждать, что гражданская культура выступает как устойчивая во времени совокупность общепринятых сдержек и противовесов, властного влияния и политической регуляции, индикатором социального содержания управленческих действий и соответствия их интересам государства.

Основными показателями развитой гражданской культуры являются закреплённый в праве этнокультурный плюрализм и абсолютная социально-экономическая персонификация участников общественных отношений. Отсутствие подобных характеристик свойственно для двух радикально-противоположных состояний общества:

• в условиях атомизации общественно-политической системы (последние годы в странах социалистического содружества);

- в условиях сплочённости и единообразия, обусловленных как естественными фракторами, так политическими (глобальные стихийные бедствия, тирании различного типа).

Современная парадигма гражданской культуры имеет глубокий исследовательский фондамент, который заложен такими мыслителями, как Н. Макиавелли, Ш. Монтескье, А. де Токвиль, Дж. Мэдисон, М. Вебер, Э. Шилз, Д. Трумэн, Дж. Сарти, Р. Даль и др. Особо необходимо отметить вклад Г. Алмонда и С. Вербы. В своих работах они первые рассматривают "гражданскую культуру" в политологическом спектре. Свежие редакции работ этих авторов на русском языке внесли неоценимый вклад в развитие российской науки на современном её этапе. Данный материал также основан на научных выводах Г. Алмонда и С. Вербы.

Недостаточный уровень исследования местного самоуправления как базового уровня государственного управления, а также неполная оценка всех его форм осуществления обуславливают основные противоречия в представлениях о гражданской культуре современной России. Преимущественно оно односторонне: дано либо через систему государственного управления, либо как нечто, свойственное гражданскому обществу, его элемент. Подобное восприятие неполноценно, если оно проявляется при осуществлении социальных исследований демократического общества. Данное утверждение базируется на мнении Г. Алмонда и С. Вербы. Те политические ориентации, которые составляют гражданскую культуру, тесно связаны с общими социальными и межличностными ориентациями. В гражданской культуре нормы межличностных отношений, общего доверия и уверенности в своем социальном окружении пронизывают политические установки и умеряют их [1, с. 474]. Социальные ориентации всегда сохраняют свою доминанту в политических установках.

Распространённое отождествление гражданской культуры с культурой гражданского общества ограничивает сореру влияния первой. Несомненно, в 
формах осуществления гражданской культуры очень многое перекликается с культурой гражданского общества. С появлением государства именно традиции и практики культуры гражданского общества стали основой гражданской культуры. Данная взаимосвязь и отличительные аспекты будут рассмотрены далее на примере территориального самоуправления в современной практике осуществления местного самоуправления России.

Можно согласиться с В. В. Ковалёвым, который считает: "Гражданская культура исходит от индивида, а не проецируется государством [5]", - но необходимо добавить, что, несмотря на это, она касается политической сферы общественных отношений, а не корпоративной сферы как в инициативах индивида при взаимодействии в формате гражданского общества. Говоря о культуре гражданского общества, которая представляет собой определённую совокупность экономических, нравственных, эстетических, семейных и других ценностей, мы выделяем её целью не гармонизацию общественных отношений в рамках политической организации общества, а сохранение гарантии невмешательства государства в сферы сугубо личного интереса (частные).

Современная концепция предполагает, что именно гражданская культура обеспечивает рост политической активности общественной жизни и әфрфективность механизмов власти при управлении государством (әфрфективность политической организации общества). То есть это взаимозависимый процесс. Поэтому гражданское качество культуры следует рассматривать не только в форме особых отношений между членами гражданского общества, в связи с разнообразием их позиций и необходимостью коллективных действий, но, прежде всего, как проявление объединяющего государственного начала в условиях различных вызовов $[7$, с. 82].

Именно гражданская культура способна абсорбировать и сконцентрировать в единый комплекс политических ценностей всю систему власти и управления обществом, отражающую определённое соотношение государственных и инициированных гражданами различных политических форм. Гражданская культура всегда оказывала влияние на фрункционирование власти как таковой и власти в различных горизонтальных плоскостях её реализации, в частности, на местном уровне, там, где складывается большая часть всех социальных взаимоотношений. Так, согласно теории Г. Алмонда и С. Вербы, гражданская культура направлена не столько на привлечение населения к активной политической деятельности, сколько на поддержание политической стабильности, развитие сотрудничества и взаимной ответственности власти и граждан в целях эффрективной реализации их интересов $[8$, c. 130]. Они отмечали, что гражданская культура - "плюралистическая культура, основанная на коммуникации и убеждении, культура консенсуса и разнообразия, культура, которая допускала изменения, но умеряла их" [1].

В качестве одного из механизмов самоорганизации граждан выступает институт местного самоуправления. В процессе формирования гражданской культуры России местное самоуправление играет важную роль [8]. Данный институт начал развиваться давно. Он не является заимствованным и имеет фундаментальные корни в российской истории. Всё начиналось с земских дворов или приказов при Иване Грозном; земских изб при Петре I; регулярных дворянских собраний, городских дум при Екатерине II; а позже данный институт получил отражение в земских собраниях и управах при Александре II и т. д [8, с. 131].

Интересным является опыт Дальнего Востока на закате Российской империи. Рассматривая влияние гражданской культуры на формирование пространства осуществления местной власти на примере Приамурского земского собора, необходимо отметить, что в данном процессе активно приняли участие представители всех слоёв русского общества: духовенства как православного, старообрядческого, так и мусульманского, представители армии и фрлота, чиновничества, предпринимательства, крестьянства, рабочих, земств, общественных и политических организаций. Этнокультурность и стратификация на основе социально-экономических персональных идентификаторов очевидны. В свою очередь, это является подтверждением достаточного уровня гражданской культуры того периода.

В 1922 г. была разработана и начала внедряться схема, сочетавшая традиционные монархические принципы и идущие снизу гражданские посылы. 
Народовластие, обеспеченное массовым участием граждан в процессах фpopмирования органов местной власти, проявлялось ярче и отчетливее. Территориальной основой Приамурского самоуправления становились церковные приходы. Органами местной власти являлись Советы приходов, во главе которых стояли пастыри и выбранные прихожанами председатели. Членами Советов могли становиться любые активные, харизматичные граждане не моложе двадцати пяти лет, которые не имели непогашенных уголовных судимостей. Это один из фрактов реализации практики всеобщего пассивного избирательного права. Советы приходов объединялись в районные Советы церковных приходов, а высшим органом самоуправления становилась Земская Дума, куда районы выбирали двух своих представителей сроком на месяц. При этом высшим органом власти оставался Земский Собор, куда каждый приход выбирал по одному представителю.

Соответственно, приход рассматривался как начальная территориальная земская единица, объединявшая граждан своего небольшого района. Они занимались решением местных нужд, т.е. вопросов местного значения, проявляя свою гражданскую инициативу. Основная идея приходского самоуправления состоит в том, чтобы свести управляющий бюрократический аппарат до минимума и воплотить в жизнь широкое самоуправление. В фрундаменте приходского самоуправления лежит общественная самодеятельность, т. е. воля народа [9].

Подобную тенденцию можно наблюдать и сегодня, церковный приход заменен на "приход" школьный, но во всём остальном преемственность в рамках сфрормированной гражданской культуры сохранена. Глава 5 Федерального закона № 131 дает объёмный перечень возможных непосредственных форм волеизъявления граждан: обращения; собрания; сходы; конференции; правотворческая инициатива; публичные слушания; выборы и, конечно, голосование на редререндуме. Список обширный, но неполный. Российский законодатель в ст. 33 Ф3 № 131 предполагает, что его можно расширить иными инструментами в рамках сложившихся культурно-исторических традиций на конкретных территориях.

Наиболее практикуемой инищиативой граждан является территориальное общественное самоуправление. На территории Российской Федерации функционирует около 35 тысяч $\mathrm{TOC}^{1}$, и список этот постоянно увеличивается. Население, самоорганизовываясь для непосредственного участия в решении вопросов местного значения, формирует территориальное общественное самоуправление в границах пространства возможного межличностного непосредственного общения, фрормируя подобие общины из жителей близлежащих 2-6 многоэтажных домов. Сегодня во Владивостоке функционирует 18 TOC [12]. Отсутствие прежнего количества приходов замещается наличием муниципальных школ, которые приобретают качества мультипликатора при организации жителей на осуществление местных инициатив.

Это позволило выделить одну из проблемных точек формирования социально-политического пространства - территориальную. Подход в определении границ территориального самоуправления, основанный на объединении вокруг традиционного для общины ценностного ряда, позволяет внятно обосновать их контур пространством естественного взаимодействия участников-акторов. Уполномоченные на регистрацию ТОС органы местной власти во Владивостоке всячески препятствуют появлению культурной скрепы при установлении границ самоуправления. Так, например, местная власть отказывается регистрировать Устав, в котором описание границ содержит пункт "школа", ссылаясь на п. 3 ст. 7 Положения № 157, в ответ на инициативу жителей ул. Юмашева или жителей о. Русский во Владивостоке. Жители за 2019 г. получили 4 отказа, хотя общественный контроль за образовательным учреждением, где учатся дети жителей, является одним из основных мотиваторов активности граждан. Это именно тот случай, когда традиции гражданской культуры станут залогом успешного предстоящего судебного разбирательства по поводу решения местной администрации, не отражающего содержания местных инициатив.

1 TOC - территориальное общественное самоуправление 
Мировой опыт, особенно опыт англо-саксонских стран свидетельствует о положительной практике местного самоуправления в "школьных районах" [6]. "Школьные районы" в Соединённых Штатах Америки включены в специальные округа, которые представляют собой административные органы, создаваемые для оказания определённого вида услуг. Данный вид округа является наиболее распространённым типом специального округа. В территорию округа включены начальные и средние школы. Границы школ могут совпадать, а могут и не совпадать с традиционными границами административно-территориальных единиц. Народное образование является одной из основных cdpep компетенции США. Школьные округа, или school district, подчиняются местным органам власти. Как правило, возглавляют школьные округа школьные советы, в состав которых избираются жители территории, проживающие на данных округах. Совет определяет школьную политику, программы, бюджеты, нанимает инспекторов и, в некоторых случаях, устанавливает уровень налогов. Контроль за работой школьного округа в большинстве штатов возлагается на орган на уровне штата, как правило, департамент образования или департамент народного просвещения [13].

На сегодняшний день участие населения в решении вопросов местного значения является одним из основных показателей уровня развития гражданского общества и гражданской культуры. В данном случае можно выделить ещё одну проблемную точку, наличие которой определено противоречиями восприятия указанных категорий, - это организационно-правовая проблема. Организационно-правовая форма регистрации территориального самоуправления не имеет чётких правовых описаний: их нет в Гражданском Кодексе РФ, нет в Федеральном законе "Об общих принципах осуществления местного самоуправления в Российской Федерации", нет в других фредеральных законах, регулирующих деятельность некоммерческих юридических лиц. Это позволяет региональным представительствам Минюста РФ регистрировать ТОС в качестве юридического лица по своему усмотрению. В Приморском крае, как и в 90 \% субъектов РФ, это регистрация в статусе "Общественная организация". Так были зарегистрированы три из трех обратившихся за регистрацией ТОС. Учитывая общий уровень местной гражданской культуры, никто не может "увидеть" в этом проблему, не может соотнести, что структурный элемент гражданского общества (общественная организация) не является элементом в системе власти. Соответственно, данный элемент не может быть создан по утверждению органа власти, не имеет территориальных, членских ограничений, однако у него должны быть учредители.

Недостаток у граждан знаний своих прав является препятствием к осуществлению гражданских инициатив. Неверие в возможность оказывать влияние на принимаемые органами власти решения основано на незнании прав. Сегодня большинство граждан не имеет опыта реализации данных им полномочий [7]. Все это определяет ещё одну болевую точку - информационную. Чтобы улучшить текущую ситуацию, местные органы власти, как никто другой, должны быть заинтересованы в постоянной работе, направленной на повышение интереса населения к деятельности муниципалитетов и внедрение форм повседневного участия жителей этих образований в решение местных проблем, создание домашних комитетов, территориального общественного самоуправления и других форм [8, с. 133].

Слабая информационно-консультационная деятельность органов власти не снимает личной ответственности с гражданина, незнание закона не освобождает от негативных последствий их несоблюдения. Вопрос гражданской культуры - это не только вопрос качественной социализации в начале жизненного цикла.

Жители объединяются и в формате ТОС получают познавательные гражданские навыки по мере решения тех или иных местных задач. В своей деятельности ТОС использует все традиционные для гражданского общества организационные инструменты и механизмы. Деятельность осуществляется посредством проведения собраний и конференций, разработки и принятия Программ, создания органов ТОС в пределах установленных законом территорий проживания граждан. Гранищы осуществления деятельности ТОС устанавливаются по предложению населения, проживающего на соответствующей территории, соответствующим представительным органом власти [10]. 
Например, в Приморском крае и Сахалинской области активно проводится работа с населением, бизнесом, общественниками, председателями советов многоквартирных домов, депутатами всех уровней и иными заинтересованными лицами как через встречи, так и посредством проведения мероприятий местного, регионального и межрегионального значения. За 2019 г. на территории Приморского края было проведено шесть семинаров и две конференции. Все мероприятия проходили с непосредственным участием представителей кафедры политологии Восточного института - Школы региональных и международных исследований Дальневосточного федеерального университета. Для реализации собственных инициатив гражданами учреждены ассоциации, объединяющие несколько граничащих между собой ТОС.

Говоря о практике реализации гражданских инициатив, обусловленных уровнем гражданской культуры, можно выделить одну из основных фонкциональных задач гражданской культуры. Способствуя фрормированию системы публичной постановки местных задач и контроля за их исполнением, гражданская культура обеспечивает оптимизацию политической власти на муниципальном уровне, легитимизирует фрункционирования её институтов, обеспечивает сохранение и укрепление общественного согласия по поводу распределения властных полномочий.

Опыт российских демократических преобразований первых десяти лет показал, что не следует приписывать всю ответственность за создание гражданского общества и повышение уровня современной гражданской культуры государству. Во многом успех этих процессов зависит от наличия әфрфективного сотрудничества и взаимной ответственности государства, общества и личности. Государство обязано создавать условия, которые обеспечат возможность самостоятельной деятельности граждан, их самоорганизации и совершенствования механизмов обратной связи между государством и гражданином $[8$, с. 131$]$.

Находясь в рамках гражданской культуры, общество обязано обеспечить демократическую направленность и устойчивость существующей системы государственного устройства. Ответственность граждан заключается в оценке государственных приоритетов национальным интересам и традициям. Подтверждая наличие общих политических установок и ценностей, общество обеспечивает всеобщую интеграцию. Именно гражданская культура содействует признанию легитимности и конструктивности политической власти, её ращионального устройства и компетентности [7, с. 83].

Гражданская культура - это специфическая система нормативного значения; она даёт представление о стабильной и эфффективной модели организации общества с точки зрения власти на всех административных и территориальных уровнях. Между властью и местным самоуправлением под влиянием гражданской культуры постепенно развиваются и консолидируются демократические принципы и нормы политических отношений $[7$, с. 83]. В результате взаимного влияния гражданской культуры и элемента политической системы любого уровня, а особенно муниципального, возникает мультипликативный эфрфект во всех процессах фрункционирования всего общественного организма.

Говоря о стабильности демократии, Г. Алмонд и С. Верба полностью развенчали мифо о том, что необразованное, бескультурное общество легко управляемо. Стабильность демократического государства напрямую зависит от гражданской культуры её населения.

Учитывая тот фракт, что место преимущественного проживания индивида - это всегда область осуществления местного самоуправления, то очевидным становится тот фракт, что взрослеющий человек в своём дворе получает не только первый опыт социальной коммуникации, но и первый гражданский опыт. Тенденция влияния гражданской культуры на формирование пространства осуществления местного народовластия должна стать некой государственной идеологией, как и патриотизм. Подобный общегосударственный подход обеспечит взаимодополняемость культуры и практики. В таком случае высока вероятность того, что эфрфективность местного самоуправления может возрасти. Необходимо обеспечить массовое гражданское участие жителей в процессах решения вопросов местного значения, аналогичное практике Приамурского земского собора. Использование территориальных и организационных моделей прошлого может обеспечить рост степени взаимного влияния 
гражданской культуры и процессов формирования стабильного социально-политического пространства на местном уровне.

\section{Литература}

1. Алмонд Г., Верба С. Гражданская культура: политические установки и демократия в пяти странах. М.: Мысль, 2014. 500 с.

2. Баталов Э. Политическая культура России сквозь призму civic culture // Pro et Contra. 2002. T. 7. № 3. C. 7-22.

3. Бурдье П. Социология социального пространства / П. Бурдье; пер. с фрр., общ. ред. Н. А. Шматко. СПб.: Алетейя, 2005. 288 с.

4. Данилова Е. О. Специфика социально-экономического пространства города: теоретический аспект // Вести Волгоградского государственного университета, 2016. № 4 (34) C. 177-192.

5. Ковалёв В. В. Гражданская культура как базовый конструкт гражданского общества // Государственное и муниципальное управление. Учёные записки СКАГС. 2014. № 1. C. 179-184.

6. Местное самоуправление в США: мэры, полиция и школьные советы. [Электронный ресурс] // SHAREAMERICA. [Электронный ресурс]. URL: https://share.america. gov/ru/местное-самоуправление-в-сша-мэры-пол/ (дата обращения: 15.01.2020)

7. Омеличкин О. В. Гражданская культура России: проблема формирования // Вестник Кемеровского государственного университета. 2015. № 2 (62) Т. 2. С. 76-83.

8. Петрова А. С. Роль местного самоуправления в формировании гражданской культуры российского общества // Управленческое консультирование, 2013. № 8 (56). C. $129-134$.

9. Приамурский земский собор. Запоздалый шаг белого движения. [Электронный ресурс] // Первый русский. Царь Град. TВ. [Электронный ресурc]. URL: https://tsargrad.tv/articles/priamurskij-zemskij-sobor-zapozdalyj-vernyj-shag-belogodvizhenija_76028 (дата обращения: 15.01.2020)

10. Развитие ТОС в России. [Электронный ресурс] // Общенациональная ассоциация территориального общественного самоуправления. [Электронный ресурc]. URL: https://www.dropbox.com/s/oqfd91 hdssfw1u1/Развитие TO. (дата обращения: 15.01.2020)

11. Савва М. В. Власть как фактор гражданской культуры в современной России // Человек. Сообщество. Управление. 2011. № 4. С. 80-91.

12. Территориальное общественное самоуправление. [Электронный ресурс] // Дума города Владивостока. [Электронный ресурc]. URL: http://www.dumavlad.ru/tos (дата обращения: 15.01.2020)

13. Шугрина Е. С. Муниципальное право: Учебник. 5-е изд., перераб. и доп. М.: Норма: НИЦЦ ИНФРА М, 2014. 576 с.

\section{Транслитерация по ГОСТ 7.79-2000 Система Б}

1. Almond G., Verba S. Grazhdanskaya kul'tura: politicheskie ustanovki i demokratiya v pyati stranakh. M.: Mysl', 2014. $500 \mathrm{~s}$.

2. Batalov Eh. Politicheskaya kul'tura Rossii skvoz' prizmu civic culture // Pro et Contra. 2002. T. 7. № 3. S. 7-22.

3. Burd'e P. Sotsiologiya sotsial'nogo prostranstva / P. Burd'e; per. s fr., obshh. red. N. A. Shmatko. SPb.: Aletejya, 2005. 288 s.

4. Danilova E. O. Spetsifika sotsial'no-ehkonomicheskogo prostranstva goroda: teoreticheskij aspekt // Vesti Volgogradskogo gosudarstvennogo universiteta, 2016. № 4 (34) S. $177-192$.

5. Kovalyov V. V. Grazhdanskaya kul'tura kak bazovyj konstrukt grazhdanskogo obshhestva // Gosudarstvennoe i munitsipal'noe upravlenie. Uchyonye zapiski SKAGS. 2014. № 1. S. 179-184.

6. Mestnoe samoupravlenie v SSHA: mehry, politsiya i shkol'nye sovety. [Ehlektronnyj resurs] // SHAREAMERICA. [Ehlektronnyj resurs]. URL: https://share.america.gov/ru/ mestnoe-samoupravlenie-v-ssha-mehry-pol/ (data obrashheniya: 15.01.2020)

7. Omelichkin O. V. Grazhdanskaya kul'tura Rossii: problema formirovaniya // Vestnik Kemerovskogo gosudarstvennogo universiteta. 2015. № 2 (62) T. 2. S. 76-83.

8. Petrova A. S. Rol' mestnogo samoupravleniya v formirovanii grazhdanskoj kul'tury rossijskogo obshhestva // Upravlencheskoe konsul'tirovanie, 2013. № 8 (56). S. 129-134.

9. Priamurskij zemskij sobor. Zapozdalyj shag belogo dvizheniya. [Ehlektronnyj resurs] // Pervyj russkij. Tsar' Grad. TV. [Ehlektronnyj resurs]. URL: https://tsargrad.tv/ articles/priamurskij-zemskij-sobor-zapozdalyj-vernyj-shag-belogo-dvizhenija_76028 (data obrashheniya: 15.01 .2020$)$ 
10. Razvitie TOS v Rossii. [Ehlektronnyj resurs] // Obshhenatsional'naya assotsiatsiya territorial'nogo obshhestvennogo samoupravleniya. [Ehlektronnyj resurs]. URL: https:// www.dropbox.com/s/oqfd91hdssfw1u1/Razvitie TO. (data obrashheniya: 15.01.2020)

11. Savva M. V. Vlast' kak faktor grazhdanskoj kul'tury v sovremennoj Rossii // CHelovek. Soobshhestvo. Upravlenie. 2011. № 4. S. 80-91.

12. Territorial'noe obshhestvennoe samoupravlenie. [Ehlektronnyj resurs] // Duma goroda Vladivostoka. [Ehlektronnyj resurs]. URL: http://www.dumavlad.ru/tos (data obrashheniya: 15.01.2020)

13. SHugrina E. S. Munitsipal'noe pravo: Uchebnik. 5-e izd., pererab. i dop. M.: Norma: NITS INFRA M, 2014. $576 \mathrm{~s}$.

Булах Е. В., Князева А. Р., Цой В. Г. Взаимное влияние процессов формирования гражданской культуры и социально-политического муниципального пространства: от Приамурского Земского собора до настоящего времени.

В представленной статье предпринята попытка подтвердить взаимное влияние гражданской культуры и процесса формирования социально-политического пространства на муниципальном уровне. Авторами выделены основы гражданской культуры, обозначены основные характерные черты общества с развитой гражданской культурой. В работе предложены основные проблемные точки развития непосредственных форм осуществления местного самоуправления, понимание которых определено уровнем гражданской культуры. Выделены взаимные обязательства государства и общества при обеспечении социальной стабильности и гармонии. Опираясь на исторический опыт от Приамурского Земского собора до настоящего времени, включая анализ зарубежного опыта, дано обоснование прямой и обратной зависимости уровня культуры и качества системы управления. В работе затронута практика решения вопросов местного значения на примере Приморского края и Сахалинской области.

Ключевые слова: гражданская культура, местное самоуправление, ТОС, Приалурский Зелский собор, народовластие, сощиально-политическое пространство

Bulakh E. V., Knyazeva A. R., Tsoj V. G. Mutual influence of the culture and the social networks forming process at the local level: from the Amur Zemsky Assembly to the present.

The article presents an attempt to confirm the mutual influence of civic culture and the process of formation of the socio-political space at the municipal level. The authors highlighted the foundations of civic culture, identified the main characteristic features of a society with a developed civic culture. The paper proposes the main problem points of the development of direct forms of local self-government, the understanding of which is determined by the level of civic culture. Mutual obligations of the state and society are highlighted while ensuring social stability and harmony. Based on historical experience from the Amur Zemsky Assembly to the present, including an analysis of foreign experience, a rationale is given for the direct and inverse relationship of the level of culture and the quality of the management system. The work touched upon the practice of resolving issues of local significance on the example of Primorsky Krai and Sakhalin Oblast.

Key words: civic culture, local government, TSP, Amur Zemsky Assembly, democracy, social and political space

Для цитирования: Булах Е. В., Князева А. Р., Цой В. Г. Взаимное влияние процессов формирования гражданской культуры и социально-политического муниципального пространства: от Приамурского Земского собора до настоящего времени // Ойкумена. Регионоведческие исследования. 2020. № 1. C. 98-105. DOI: 10.24866/1998-6785/2020-1/98-105

For citation: Bulakh E. V., Knyazeva A. R., Tsoj V. G. Mutual influence of the culture and the social networks forming process at the local level: from the Amur Zemsky Assembly to the present // Ojkumena. Regional researches. 2020. № 1. P. 98-105. DOI: 10.24866/1998-6785/2020-1/98105 


\section{Региональный парламентаризм в условиях снижения әффективности системы представительства}

Становление парламентских институтов, происходящее в современной России, преобразует политическую жизнь не только на федеральном, но и на региональном уровне [1, с. 7]. Положение, высказанное в 2000 г., остается современным и спустя два десятилетия, однако вектор развития и направления взаимовлияния парламентов и институтов гражданского общества существенно изменились.

За последние десятилетия законодательная власть субъектов РФ не раз меняла содержание и объем своих полномочий, расширяя и сужая сферы своего влияния, но, в любом случае, стала заметной и весьма активной составляющей отечественного политического ландшафта. Проблема становления региональной государственной власти вообще, и регионального парламентаризма, в частности, до настоящего времени остается одной из самых важных во всей системе государственного устройства Российской Федерации.

Известный исследователь политического процесса на Дальнем Востоке РФ Е. В. Буянов в 1998 г. разработал периодизацию процесса государственного строительства в России, где отмечает, что "с точки зрения политического и правового анализа данный процесс в России в период с 1990 по 1997 гг. явственно распадается на четыре больших этапа:

- середина 1990 - август 1991 г.;

- сентябрь - декабрь 1991 г.;

- начало 1992 - декабрь 1993 г.;

- 1994 - 1997 г." [2, с. 14].

Существует и другая периодизация данного процесса, которая также выделяет четыре этапа разграничения компетенции федерации и ее субъектов: первый охватывает трехлетие от "парада суверенитетов" 1990 г. до редеерендума 1993 г. Второй, самый продолжительный, длился от принятия Конституции РФ до августовского кризиса 1998 г. Третий маркировался началом деятельности правительства Е. Примакова, с одной стороны, и избранием В. Путина на пост Президента России, с другой. Четвертый продолжается и по сей день [3, с. 109].

Более точной по отношению к процессу становления приморского парламентаризма, на наш взгляд, является периодизация, разработанная Е. В. Буяновым, которую можно дополнить двумя этапами: 1998-2003 гг. как период существования федерации в ранее установленных рамках; с 2003 г. по настоящий момент как период рефрормирования основ фредерализма, ознаменованный пересмотром объемов полномочий регионов и центра и редрормой в области формирования исполнительной власти регионов-субъектов федерации.

Таким образом, определяя региональный парламентаризм, как институционально сформированную, но содержательно недостаточно наполненную систему властных отношений, базирующуюся на формальном признании демократических основ взаимодействия государства, общества и личности, мы предполагаем достаточно сложную систему отношений государства, социальных институтов и непосредственно граждан.

Рассматривая роль парламента, как центрального ядра парламентаризма, несущего в себе возможности как реализации властных полномочий, так и легитимации государственной власти, мы обратим внимание на законодательные и представительные функции приморской легислатуры.

ТАНЦУРА Марина Сергеевна, канд. полит. наук, доцент, доцент кафедры политологии Дальневосточного федерального университета (2. Владивосток). E-mail: tatuika@mail.ru 
Таблица 1. Количество вновь переизбранных депутатов 3СПК (3-6 созывы)

\begin{tabular}{|c|c|c|c|c|}
\hline Созыв & 2002-2006 & 2006-2011 & 2011-2016 & 2016-2021 \\
\hline Количество переизбранных депутатов & $7(17,5 \%)$ & 7 & $17(42,5 \%)$ & $16(40 \%)$ \\
\hline
\end{tabular}

Источник: составлено на основе [4; 5].

В рамках исследования места и роли регионального парламента в процессе фрормирования и фрункционирования системы коммуникации "граждане - власть" можно выявить несколько основных направлений анализа. Во-первых, мы наблюдаем завершение процесса правовой трансформации легислатуры: законодательные рамки деятельности четко очерчены; Законодательное собрание Приморского края (ЗСПК) на данный момент выступает слабым парламентом при сильной исполнительной власти, являясь, по сути, зеркальным отражением процессов, протекающих на фредеральном уровне. А современный российский парламентаризм существует на фоне сильной президентской власти и функционирует в условиях дисбаланса полномочий между законодательной и исполнительной ветвями власти в пользу последней. Современную модель российского парламентаризма можно отнести к авторитарной, построенной на ограничении власти парламента и одновременном усилении власти президента. Для сохранения контроля над парламентом исполнительная власть также использует неформальные методы поощрения членов парламента и оказания на них влияния [7].

На уровне субъекта ситуация схожа: практически неограниченный фуннкционал губернатора усиливается максимально лояльными к исполнительной власти парламентариями. Состав ЗСПК персонально меняется чаще в процессе межэлитной борьбы и передела сфер влияния при смене глав региона, чем в рамках текущего электорального процесса. Население, несмотря на возможность выбирать своих представителей, фактически такого выбора не делает, имея достаточно ограниченные возможности для выбора из все той же, "старой, потрепанной" колоды кандидатов и партий.

Если провести анализ персонального состава ЗСПК, то складывается явная тенденция: в последний раз практически полностью состав парламента обновился к четвертому созыву, после перехода на смешанную систему выборов. Последние три состава обновлялись примерно на $60 \%$.

Парламент как орган народного представительства институционализирует господствующие в обществе многочисленные интересы, политические ориентации и настроения. Он выступает в качестве института гражданского общества, выполняющего фрункцию соединения суверенитета народа с государственной властью, и тем самым указывает на подлинный источник власти. Выступая от имени народа, парламент получает широкую социальную поддержку и открытость. Народная поддержка позволяет парламенту придать системе государственного управления демократический характер, и быть активным участником процесса по легитимации политической власти. Способность выявлять социальные потребности, концентрировать и открыто выражать общественные интересы позволяет парламенту стать публичной ареной, где на основе свободного обмена мнениями преодолеваются накопившиеся противоречия между различными субъектами власти, государством и гражданским обществом [8].

Исследование функций и ролей региональных парламентских институтов лежит на стыке политической и юридической науки. Выявление четких параметров әфффективности деятельности легислатур является достаточно серьезной проблемой в силу неопределенности нормативно-правовой базы, и преобладания качественных оценок деятельности институтов, что добавляет этим оценкам субъективизма. Критерии әфрфективности определяются, таким образом, политико-правовым статусом в системе законодательной власти и в целом в политической системе РФ; они обусловлены объемом наличных ресурсов реального влияния региональной законодательной власти как политического института. Также критерием әффективности является качество представительства интересов электоральных групп в процессе законотворче- 
ства и продуктивность участия в законотворческой деятельности на уровне фредерации.

В современной политологии все большую популярность приобретает позиция, подчеркивающая тенденцию снижения әффективности системы представительства, обеспечивающейся фрункционированием парламентов и формирующих их партий. Это связано как с распространением менеджериальных подходов к управлению, так и с изменением требований многосоставного общества и механизмов определения "повестки дня" [10]. Кризисное состояние системы представительства в России детерминируется особенностями политической трансформации, в ходе которой представительные органы всех уровней не получили серьезного влияния на распределение ресурсов, а потому не стали значимы для общества и не пользуются его поддержкой.

Попытаемся выделить факторы, на наш взгляд, влияющие на эффрективность системы представительства.

Факторы, снижающие возможность для регионального парламента реализовывать свою представительную функцию, обширны, и не всегда непосредственно зависят от самого института.

Первым, и наиболее влиятельным выделим уже упомянутый нами "эффрект зеркала" - роль и место ЗСПК в системе власти серьезно детерминировано ролью и местом Федерального Собрания (ФС) РФ в системе разделения властей. Помимо законодательно зафиксированной "слабости", парламент не интересен гражданам (уровень одобрения не поднимается выше 40 \%) [6]. Его деятельность не является существенной для рядового избирателя, так как большинство граждан не видит возможности агрегировать и защитить свои интересы через представительные институты.

Сощиологические исследования, проводимые в различные периоды и разных регионах, показывают, что уровень доверия населения к лидерам исполнительной власти, как фредерального, так и регионального уровня, выше, чем законодательной власти, что обусловлено, в первую очередь, наличием у исполнительной власти реальных материальных ресурсов и рычагов влияния. Это второй фрактор, серьезно снижающий роль представительной власти.

Также, существует мощное, и вряд ли преодолимое мнение о неповоротливости, низкой производительности, отсутствующей реактивности парламентских институтов. Законотворчество, принятие бюджета - это, по сути, утверждение решений исполнительной власти, без которого можно обойтись (многие еще помнят ельцинское "указное право"). Данная позиция очень глубоко укоренена в традициях этатизма, прочно живущих в головах россиян. Региональные парламенты осуждают за неповоротливость бюрократического аппарата, обеспечивающего деятельность законодательной власти. Мало кто из избирателей учитывает, что депутатский запрос может быть потерян или проигнорирован соответствующими структурами другой, исполнительной, ветви. Однако гражданин, не получив ответа от законодателя, полностью теряет доверие к представительным структурам.

Не способствует повышению доверия к региональным законодательной органам и широкое внедрение в избирательную практику административных технологий, а также низкая информированность населения об их полномочиях, деятельности и принципах формирования. ЗСПК периодически информирует граждан о своей деятельности, официальный сайт постоянно обновляется, но общество не придает значения этим сообщениям, создавая тем самым "замкнутый круг" проблем российской системы представительства.

Еще один существенный момент, снижающий әфрективность системы представительства - стереотипность ее восприятия, как места, где преобладают неформальные связи, куда невозможно попасть и добиться правды. Региональные парламенты проще справляются с данной проблемой, в отличие от ФС РФ. Депутат региональной легислатуры, даже если избран по партийным спискам - это человек, тесно связанный с избирателем, хорошо известный в своем округе. $\mathcal{K}$ нему можно записаться на прием, написать обращение, встретить в своем округе. Подобная персонализация дает достаточное количеств преимуществ в случае, если депутат реагирует на запросы избирателей, даже формально, и не замешан в крупных скандалах.

Снижение уровня эффрективности системы представительства тесно связано со снижением роли партийной представительности. Роль политических 
партий, особенно в их классическом понимании снижается, уступая место альтернативным формам политической активности. Но если государствах с развитой традицией представительства и активистской политической культурой роль партий успешно берут на себя группы интересов и политические сети, то в России данной традиции не сложилось. Коммунитаризм, желание подчиняться, а не участвовать, влечет за собой отрицание каких-либо структур представительства. Наблюдаемый рост ценности политического активизма среди молодежи скорее подтверждает данное положение.

Однако современное состояние регионального парламентаризма в контексте существующей социально-политической действительности дает возможности для повышения роли представительных органов государственной власти и тем самым, увеличения эфрфективности самой системы представительства.

Одна из основных возможностей повышения эффеекивности представительства коренится в изменившейся системе коммуникации. Появление социальных сетей, работа интернет-порталов и приемных парламентов, возможность лично "постучаться" в "Инстаграмм" или "Одноклассники" к своему депутату, задать ему вопрос практически лично, получить почти любую информацию онлайн - все это дает нам возможность ощутить, что власть становится более доступной, более личностной, очеловеченной. Такого рода сближение дает возможности для расширения каналов обратной связи. Парламентские институты получают возможности для преодоления излишней бюрократичности и неповоротливости, и соответственно, повышения легитимности. Основная проблема - готовность власти принять и обработать запрос.

Система государственной власти Российской Федерации выстроена по принципу вертикали. С одной стороны, это дает определенную устойчивость сложной многоуровневой федерации, а с другой - не позволяет выстраивать устойчивые межрегиональные связи, минуя центр. И здесь коренится еще одна возможность для расширения горизонтальных связей, повышающих эффрективность представительства. Модель "железного треугольника" может быть постепенно вытеснена политическими сообществами и проблемными сетями. "Проблемные сети" - это серьёзная демократическая и неискусственная попытка решить проблемы социума, созданные моделями традиционного и "нового государственного управления". Подобный "третий путь" экспертократии не ограничивает демократический процесс, а старается уйти от ограниченных коммерческих и бюрократизированных технологий прежних управленческих моделей [9, с. 85]. Потребность социума в фрормировании горизонтальных связей очень высока на уровне регионов. Создаются околополитические структуры, которые, действуя и в коммерческом, и в сощиальном пространстве, стараются активно влиять на политическую среду. В Приморье мы наблюдаем периодический заход в исполнительную власть представителей коммерческих структур, возлагающих на себя параллельную социальную нагрузку (В. Веркеенко, К. Богданенко). Депутатов ЗСПК, управляющих крупным бизнесом было традиционно много во всех составах парламента, однако серьезной активности в области социального саморегулирования пока не отмечается.

Уже упоминаемый нами политический активизм может стать действенным инструментом повышения эффрективности парламентаризма. Интересно исследование Е. Б. Шестопал, которая, анализируя социально-демографические особенности восприятия государственной власти в России на протяжении последних двадцати пяти лет, наряду с заменой либеральных ценностей консервативными с доминированием традиционных систем представлений, ценностей, образов в массовом сознании, отметила неожиданный рост ценности активизма.

Выяснилось, что как-то незаметно подросло поколение тех, кто родился уже в постсоветской России, и в ходе первичной социализации усвоил демократические ценности, включая активизм как норму гражданского поведения. Однако, активизм может проявить свой позитивный потенциал лишь в совокупности с развитием таких свойств демократического сознания, как ответственность, уважение к закону и самостоятельность политического мышления, которые сами собой не возникают. Они формируются только в процессе 
серьезных и систематических усилий со стороны государства, политических партий и других институтов социализации [11].

Таким образом, исследовав региональный парламентаризм через призму эфрфективности системы представительства, мы пришли к следующим выводам.

При существующей системе устройства органов государственной власти, современном состоянии законодательства и выстроенной системе разделения властей, именно региональные легислатуры обладают серьезными возможностями для повышения әфффективности представительности. Возможности прямой коммуникации с избирателями, законодательная поддержка процесса формирования горизонтальных связей, участие в формировании внепартийных политических сообществ - это те ресурсы, которые, находясь в руках законодателей, при наличии политической воли могут дать мощный толчок развитию институтов гражданского общества, которые, в свою очередь, в состоянии не только требовать и отстаивать свои интересы, но и снижать уровень социальной напряженности в условиях системного кризиса.

\section{Литература}

1. Автономов А. С. Региональные парламенты в современной России / А. С. Автономов, А. А. Захаров и др. М.: МОНФ, 2000. 88 с.

2. Буянов Е. В. Государственное строительство на Дальнем Востоке России в 1990-1997 годах / Е. В. Буянов. Благовещенск: АмГУ, 1998. 170 с.

3. Галкин А. А. Эволюция российского федерализма / А. А. Галкин, П. А. Федосов, С. Д. Валентей, В. Д. Соловей // Полис. 2002. № 3. С. 96-128.

4. Законодательное Собрание Приморского края. Состав. [Электронный ресурс]. URL: http://www.zspk.gov.ru/deputy/ (дата обращения: 2.12.2019).

5. Законодательное Собрание Приморского края. Предыдущие созывы. [Электронный ресурc]. URL: http://www.zspk.gov.ru/about/history/istoriya-deputatstva/ (дата обращения: 2.12.2019).

6. Индикаторы одобрения органов государственной власти. [Электронный ресурс]. URL: https://www.levada.ru/indikatory/odobrenie-organov-vlasti/ (дата обращения: 12.01.2020).

7. Керимов А.А. Институт парламентаризма в легитимации политической власти в современной России: акторы, стратегии, ресурсы / А. А. Керимов. Автореф. дисс. доктора полит. наук. Екатеринбург, 2018.

8. Керимов А.А. Парламентаризм и легитимность политической власти: обоснование взаимосвязи / А. А. Керимов // Вестник Московского государственного областного университета (электронный журнал). 2015. № 2. [Электронный ресурс]. URL: https://evestnik-mgou.ru/ru/Articles/View/638. (дата обращения: 12.12.2019).

9. Федорченко С. Н. Сетевой подход в политическом менеджменте / С. Н. Федорченко // Вестник МГОУ. Серия "История и политические науки". 2014. № 2. C. $81-87$.

10. Шашкова Я. Ю. Региональные законодательные (представительные) органы в ценностно-когнитивном пространстве россиян /Я. Ю. Шашкова // Известия Алтайского гос. университета. 2013. Серия "История. Политология". № 4-2 (80). С. 306-310.

11. Шестопал Е. Б. Проект длиною в четверть века. Исследование образов власти и лидеров в постсоветской России (1993-2018) / Е. Б. Шестопал // Полис. 2019. № 1. C. 9-20.

\section{Транслитерация по ГОСТ 7.79-2000 система Б}

1. Avtonomov A. S. Regional'nye parlamenty v sovremennoj Rossii / A. S. Avtonomov, A. A. Zakharov i dr. M.: MONF, 2000. 88 s.

2. Buyanov E. V. Gosudarstvennoe stroitel'stvo na Dal'nem Vostoke Rossii v 19901997 godakh / E. V. Buyanov. Blagoveshhensk: AmGU, 1998. 170 s.

3. Galkin A. A. EHvolyutsiya rossijskogo federalizma / A. A. Galkin, P. A. Fedosov, S. D. Valentej, V. D. Solovej // Polis. 2002. № 3. S. 96-128.

4. Zakonodatel'noe Sobranie Primorskogo kraya. Sostav. [Ehlektronnyj resurs]. URL: http://www.zspk.gov.ru/deputy/ (data obrashheniya: 2.12.2019).

5. Zakonodatel'noe Sobranie Primorskogo kraya. Predydushhie sozyvy. [Ehlektronny] resurs]. URL: http://www.zspk.gov.ru/about/history/istoriya-deputatstva/ (data obrashheniya: 2.12.2019). 
6. Indikatory odobreniya organov gosudarstvennoj vlasti. [Ehlektronnyj resurs]. URL: https://www.levada.ru/indikatory/odobrenie-organov-vlasti/ (data obrashheniya: 12.01.2020).

7. Kerimov A. A. Institut parlamentarizma v legitimatsii politicheskoj vlasti v sovremennoj Rossii: aktory, strategii, resursy / A. A. Kerimov. Avtoref. diss. doktora polit. nauk. Ekaterinburg, 2018.

8. Kerimov A. A. Parlamentarizm i legitimnost' politicheskoj vlasti: obosnovanie vzaimosvyazi / A. A. Kerimov // Vestnik Moskovskogo gosudarstvennogo oblastnogo universiteta (ehlektronnyj zhurnal). 2015. № 2. [Ehlektronnyj resurs]. URL: https:// evestnik-mgou.ru/ru/Articles/View/638. (data obrashheniya: 12.12.2019).

9. Fedorchenko S. N. Setevoj podkhod v politicheskom menedzhmente / S. N. Fedorchenko // Vestnik MGOU. Seriya "Istoriya i politicheskie nauki". 2014. № 2. S. $81-87$.

10. Shashkova Ya. Yu. Regional'nye zakonodatel'nye (predstavitel'nye) organy v tsennostno-kognitivnom prostranstve rossiyan /Ya. Yu. Shashkova // Izvestiya Altajskogo gos. universiteta. 2013. Seriya "Istoriya. Politologiya". № 4-2 (80). S. 306-310.

11. Shestopal E. B. Proekt dlinoyu v chetvert' veka. Issledovanie obrazov vlasti i liderov v postsovetskoj Rossii (1993-2018) / E. B. Shestopal // Polis. 2019. № 1. S. 9-20.

\begin{abstract}
Танцура М. С. Региональный парламентаризм в условиях снижения әффективности системы представительства.

Рассматриваются особенности реализации парламентаризма в Приморском крае. Отмечается, что в современной политологии общепризнанным становится тезис о снижении эфффективности системы представительства, выявляются факторы, влияющие на её снижение в регионе, такие как ограниченность влияния на исполнительную власть, низкий уровень доверия легислатурам, стереотипность восприятия гражданами и т.д. Рассматриваются возможности для повышения роли представительных органов государственной власти и тем самым, увеличения эффрективности самой системы представительства.
\end{abstract}

Ключевые слова: субъект РФ, парламентаризл, систела представительства, политические ценности, эбббективность

Tantsura M. S. Regional parliamentarism in the context of decreasing efficiency of the representation system.

The article considers the features of the implementation of parliamentarism in the Primorsky territory. It is noted that in modern science the assumption concerning the reduced efficiency of the system of representation, identifies the factors influencing the region, such as limited influence on the executive power, low level of trust to the legislatures, the stereotype of the perception of citizens, etc. The opportunities are being considered to enhance the role of the representative bodies of state power and thereby increasing the efficiency of the system representation.

Key words: the territories of the Russian Federation, parliamentarism, representation system, political values, efficiency

Для цитирования: Танцура М. С. Региональный парламентаризм в условиях снижения эффрективности системы представительства // Ойкумена. Регионоведческие исследования. 2020. № 1. C. 106-111. DOI: 10.24866/1998-6785/2020-1/106-111

For citation: Tantsura M. S. Regional parliamentarism in the context of decreasing efficiency of the representation system // Ojkumena. Regional researches. 2020. № 1. P. 106-111. DOI: $10.24866 / 1998-6785 / 2020-1 / 106-111$ 


\section{Опыт Вьетнама по борьбе с наркотиками}

Актуальность исследования заключается в том, что Вьетнам является одним из плацдармов для распространения наркотических веществ из стран "Золотого треугольника" в страны Северо-Восточной Азии. Транзит наркотических и психотропных веществ через территорию страны угрожает безопасности не только Вьетнама, но и Юго-Восточной и Северо-Восточной Азии, так как в дальнейшем наркотики попадают на рынки Китая, Тайваня и других стран региона, откуда их активно сбывают в другие страны мира. Также наркотики приводят к росту преступности как в рассматриваемой стране, так и в регионе, а доходы от наркопреступности идут на развитие местных преступных группировок.

Цель исследования заключается в оценке эффективности ведения предупреждения и борьбы с наркотиками во Вьетнаме.

Во Вьетнаме, несмотря на самое суровое законодательно установленное наказание в виде смертной казни, приобрести наркотики довольно просто; многие туристы знают, что в этой стране несложно купить как легкие наркотики, например, марихуану, так и самые тяжёлые и опасные их виды.

Несмотря на доступность наркотиков, в стране всё же ведётся борьба с этим видом преступности. Например, по сравнению со странами Латинской и Центральной Америки, во Вьетнаме отсутствуют крупные плантации, а также крупные группировки, занимающиеся продажей наркотиков. Тем не менее Вьетнам стал плацдармом для транспортировки наркотиков из "Золотого треугольника" в страны Северо-Восточной Азии, и служат этому следующие причины: колонизация, нищета, войны XX в. и географическое положение страны.

Исторически вьетнамцы употребляли лёгкий наркотик под названием "бетель". Бетельную жвачку готовили из семян пальмы арека катеху, которая росла почти в каждом доме $[1$, с. 154]. Древние вьетнамцы не использовали растение в целях получения "кайфа", с помощью бетеля достигался необходимый фризиологический эффрект: вещество обладает тонизирующим и возбуждающим действием и, вдобавок, снижает голод и боль [3, с. 191]. Однако бетель со временем запретили, так как при соприкосновении со слюной он приобретает кирпичный цвет и со временем улицы окрашивались в красный цвет от уже жёванного бетеля. Тем не менее культура жевания бетеля до сих пор сохраняется у многих народностей ЮВА, так как растение не является мощным психотропным средством и не вызывает агрессию. Таким образом, бетель можно считать первым наркотическим средством во Вьетнаме, которое до сих пор употребляет местное население. Однако данный вид вещества в большей степени распространён среди взрослого населения, и в настоящее время в молодёжной среде жевать бетель уже не модно.

Появление сильных наркотиков в стране связано в основном с приходом европейцев. Мысль о том, что Запад "отравил" наркотиками вьетнамский народ выразил еще Хошимин в 1945 г.: "Колонисты травили наш народ алкоголем и наркотиками, чтобы ослабить его, сделать наших людей ленивыми, злыми и коррумпированными" [17].

К тому же появлению наркотиков во Вьетнаме поспособствовали китайские эмигранты во время опиумных войн. Проиграв в этих войнах, Китай был вынужден импортировать опиум под напором англичан. Этот импорт стал причиной распространения опиума не только в Китае, но и в странах, где проживали китайские эмигранты [9].

ИЛЬИН Владимир Евгеньевич, магистрант кафедры Тихоокеанской Азии Дальневосточного федерального университета (ә.Владивосток). E-mail: vova.vladimir.ilin@mail.ru 
Дальнейшее распространение опиума осуществлялось в колониях Франции и Великобритании, которые не только не препятствовали, но и способствовали продаже наркотиков через страны ЮВА в Китай. Более того, созданные в прошлом веке связи и пути до сих пор используются контрабандистами. На данный момент выделяют два основных маршрута, проходящих через Вьетнам: южный, который проходит через Таиланд; и северный - через южные провинщии Китая и далее в Восточную Азию [5, с. 322].

Война с США также повлияла на распространение наркотиков. Ветераны американской войны рассказывали, что принимали стимулирующие препараты, а Палата представителей США в 1971 г. опубликовала доклад, в котором было показано, что с 1966 г. по 1969 г. вооружённые силы США приняли 225 миллионов таблеток. По большей части они принимали декседрин - препарат, получаемый из амфетамина [29]. Солдатам была приписана определённая доза в 20 мг на 48 часов, однако мало кто соблюдал её. Кроме того, у американских военных хватало денег для покупки наркотиков из Камбоджи и Лаоса, и к 1973 г. примерно 34 \% солдат принимали героин [21]. Как итог, всё это сильно повлияло на рост спроса на наркотики на юге Вьетнама. Вдобавок появились новые маршруты наркоторговли из Камбоджи в южные регионы страны.

С окончанием эпохи колониализма и войн XX в. фракторы распространения наркотиков в стране изменились. На современном этапе можно выделить следующие из них:

1. Получение удовольствия - люди принимают наркотики, чтобы поднять себе настроение.

2. Желание "забыться" - в попытках борьбы с депрессией, стрессом и напряжением, а также в стремлении отвлечься от неблагоприятного образа жизни часть населения употребляет не только алкоголь, но и наркотики.

3. Повышение умственных, фиизческих и других способностей - в современном мире количество информации настолько огромно, что люди просто не успевают её усваивать, в связи с чем возникает необходимость принимать различные стимуляторы, которые могут краткосрочно повысить работоспособность.

4. Доступность и разнообразие - несмотря на борьбу с распространением наркотических средств, с каждым годом появляются новые и более сильные их виды, которые не сразу можно идентифицировать как наркотические. Следовательно, борьба с распространением наркотиков усложняется.

5. Коррупция вьетнамских военных и полицейских. Органы, которые призваны бороться с наркотиками, занимаются их распространением или помогают преступным группировкам в продаже и транзите наркотиков [14, с. 39-53]. Согласно индексу восприятия коррупции 2019 г., который рассчитывается организацией Трансперенси Интернешнл (Transparency International), Вьетнам занимает 96 место в мире, что говорит о высоком уровне коррупщии в стране [7].

Под воздействием этих фракторов возникают современные проблемы Вьетнама в сорере борьбы с наркоторговлей. Первая проблема - неблагоприятность географического положения страны. С одной стороны, Вьетнам граничит с частью стран печально известного азиатского "Золотого треугольника", куда входят Таиланд, Лаос и Бирма (Мьянма) - значительная часть наркотических средств поступает именно из этих стран. "Золотой треугольник" уже давно является источником поступления огромного количества героина, что и объясняет превалирующее положение этого вида наркотика. В общем, можно выделить пять стран, где производится $90 \%$ всего героина в мире: Афрганистан, Колумбия, Мексика, Лаос и Мьянма [2, с. 142]. Только в одной Мьянме производится 40 тонн героина в год, которые затем вывозят и продают в странах ЮВА и Китае [2, с. 144]. Наркотики довольно несложно провезти через границу Камбоджи и Лаоса, где за действиями контрабандистов следят в недостаточной мере, распространению наркотиков способствуют коррумпированные правоохранительные органы. Кроме этого, территорию стран разделяют джунгли и горы, что затрудняет эфрфективное отслеживание всех перемещений наркоторговцев.

Вторая проблема - изменение маршрутов, по которым преступники провозят наркотики, что затрудняет действия полиции по их обнаружению. 
Некоторые виды наркотиков попадают во Вьетнам через морские порты, которые всегда являлись местом развития теневой экономики и контрабанды запрещённых веществ и предметов, и прибрежные города, такие как: Нячанг, Муйне, Хошимин и Хайоронг. Небольшие партии наркотических средств также приходят из стран Европы и Африки. Вьетнаму тяжело контролировать такое количество маршрутов, чем и пользуются наркоторговцы.

Третьей проблемой предупреждения и борьбы с наркотиками является разнообразие наркотических средств. Даже профрессиональный борец с данным видом преступности не назовёт все из них. Стимуляторы, психотропные вещества, лёгкие, синтетические, природные и тяжёлые наркотики - от некоторых из этих видов люди просто расслабляются; от других же могут умереть, приняв всего одну дозу. По данным Министерства общественной безопасности Вьетнама, в 2017 г. официально было зафиксировано около 210 тыс. "зависимых" [15]. Уже в 2018 г. число наркозависимых в стране достигло около 225 тыс. [19]. Стоит отметить, что официальная статистика не учитывает сотни тысяч других людей, употребляющих наркотики, так как не все вещества приводят к зависимости и требуют комплексного лечения. Правоохранительные силы не сразу могут определить, что обнаруженное вещество является психотропным или наркотическим, и это, в свою очередь, усложняет работу по борьбе с наркотиками.

Среди видов наркотиков, которые чаще всего ввозят во Вьетнам и дальше распространяют в Северо-Восточной Азии, можно выделить героин, кокаин, метамфетамин, ЛСД, марихуану, гашиш, марки и экстази. Наиболее распространённые из них - героин, экстази и метамфетамин; именно эти виды наркотиков чаще всего обнаруживают полиция и военные. По данным Министерства общественной безопасности 60-70\% всех наркоманов пострадали от употребления синтетических наркотиков [19].

В настоящее время героин является одним из самых сильных наркотиков: он приводит к снижению мозговой деятельности и разрушению центральной нервной системы, а его употребление во многих случаях приводит к смерти [14, с. 23].

Экстази или по-научному MDMA - химический наркотик, получаемый из различных веществ. По своим свойствам он похож на амфетаминоподобные вещества, которые вызывают галлюцинации и возбуждение ЦНС. Экстази не имеет такого длительного эффректа, как героин, эффрект от принятия длится от 1 до 6 часов (однако бывают случаи, когда әфрект длится до 32 часов) [14, c. 26-27].

Метамфетамин впервые был изобретён в 1893 г., но особое распространение получил относительно недавно, в связи с появлением американского сериала "Во все тяжкие". Обычно наркотик имеет белый цвет и по своим свойствам похож на экстази. Однако эффрект от метамфетамина длится несколько дольше - около 12 часов, что делает его более эфффективным по сравнению с экстази [14, с. 29].

С начала 1990-х гг. Вьетнам официально начал продвигать идею о том, что наркотики - это "социальное зло", которое необходимо искоренить. В статье 61 Конституции 1992 г. сказано, что употребление наркотиков является "заболеванием, которое представляет угрозу для общества" [16]. В Законе 2000 г. о предупреждении и борьбе с наркотическими средствами прописано, что "наркотики представляют опасность как для общественного здравоохранения, так и для национальной безопасности" [13, с. 5].

Правительство Вьетнама постоянно усиливает меры по предупреждению и борьбе с наркотрафикком. За прошедшие годы были выявлены и арестованы тысячи лиц, связанных с продажей, хранением и употреблением наркотических средств. Согласно статистическим данным, в первой половине 2017 г. было выявлено и арестовано около 12 тыс. человек, что на 2 тыс. больше по сравнению с 2016 г. Правоохранительными органами было изъято 442 кг героина, 779 кг метамфетамина, 350 кг синтетического героина, почти 90 кг опиума, 85 кг марихуаны, 1,5 кг кокаина, 5 кг гашиша и множество других веществ [24]. В 2019 г. только в одном городе Хошимине полиция обнаружила около 4 тысяч человек, замешанных в торговле, хранении и перевозке наркотиков. Правоохранительными органами было возбуждено 1372 дела, изъято почти 345 кг героина (в 3 раза больше по сравнению с 2018 г.); 1,3 
тонны синтетических наркотиков (в 2 раза больше по сравнению с 2018 г.); 40 872 кг марихуаны и 32,9 кг других наркотиков [28]. Стоит отметить, что, по мнению вьетнамских полицейских, бороться с распространением наркотиков существующими методами не очень эфрфективно, так как, потеряв один "канал", по которому во Вьетнам поступали наркотические средства, преступники практически сразу же находят другие пути проникновения на территорию страны. Кроме того, преступники находят новые и всё более изощрённые способы транспортировки наркотиков в страну. В итоге, как отметил заместитель директора департамента полиции города Хошимин полковник Динь Тхань Нян, полиция изымает не более 20 \% наркотиков, попадающих в страну, в то время как 80 \% наркотических средств проникает вглубь страны [22].

Важным инструментом борьбы с наркотиками в стране является пограничный контроль за действиями наркоконтрабандистов в кооперации с правоохранительными органами Камбоджи, Лаоса и Китая. Кроме того, борьбу с наркотиками возложили на различные министерства. Например, Министерство здравоохранения проверяет все химические вещества, в том числе и медицинские препараты, которые попадают на территорию Вьетнама с целью выявления наркотических средств; Министерству торговли поручено вести контроль над импортом и экспортом наркотиков; Министерство общественной безопасности ведет контроль над другими способами доставки наркотиков на территорию страны $[1 \mathbf{1}$, с. 6]. Однако, как уже отмечалось выше, Вьетнаму сложно следить за своими сухопутными границами на всей их протяженности, правоохранительным органам не всегда известны пути проникновения наркоторговцев на территорию Вьетнама.

Одной из мер по борьбе с распространением наркотиков является пропаганда среди молодежи, которая несёт систематический характер: врачи и полицейские приходят в учебные заведения, где ведутся беседы со школьниками и студентами о вреде употребления наркотиков, незаконности их покупки, продажи и т. д. Однако данная работа не всегда приводит к эффрективному результату. Например, в отдалённых районах страны и среди национальных меньшинств такую работу проводить проблематично, так как население в таких местах не отличается финансовым благополучием, а контрабанда наркотиков является лёгким способом заработка для местного населения.

Ещё одним из способов борьбы с наркопреступностью является смертная казнь. Преступники приговариваются к такому наказанию в зависимости от объема продаж наркотиков и их видов. Согласно Резолюции № 01/2001/ NQ-HDTP Совета судей Верховного народного суда, за продажу от 100 до 300 грамм героина налагается наказание в виде 20 лет лишения свободы; от 300 до 600 грамм - пожизненное лишение свободы; а за продажу от 600 грамм и более преступник приговаривается к смертной казни [23]. Данные о количестве приговоренных к смерти людей секретны и закрыты для общего доступа, но согласно данным всемирного обзора, сделанного организацией "Международная Амнистия" (Amnesty International), Вьетнам в 2018 г. вошел в четвёрку стран с наибольшим числом людей, приговорённых к смертной казни [4, c. 4]. Тем не менее, как мы видим, наличие смертной казни не останавливает преступников, и они продолжают продавать наркотики.

Лечение и реабилитация страдающих от наркозависимости людей также является частью предупреждения и борьбы с наркотиками во Вьетнаме. В 2018 г. во Вьетнаме было открыто около 120 центров обязательного лечения наркозависимых людей. При этом стоит отметить, что это на 25 центров меньше по сравнению с 2014 г. [19]. Лечение в данных центрах является принудительным, а не добровольным. В целом, пациенты находятся в центре около двух лет; после окончания этого срока проводится осмотр, где определяют состояние человека. Если выявляется склонность к рецидиву, то пациента оставляют в центре еще на два года. Более того, если после прохождения лечения пациенты снова прибегают к употреблению наркотиков, то они получают наказание в виде лишения свободы на срок от трех до шести месяцев [13, с. 6]. Однако по поводу эффрективности этих центров существуют большие сомнения. Отмечается, что условия жизни в них схожи с жизнью в тюрьме, где людей избивают палками и электрическими дубинками в случае попытки сбежать. Представители центров говорят, что лечение основано на "трудовой 
терапии", так как это является эффрективным способом восстановления человека, который после окончания лечения сможет устроиться на работу и заново интегрироваться в общество $[13$, с. 6$]$.

В 2017 г. вьетнамское правительство разработало программу профилактики и борьбы с наркотиками до 2020 г. Программа направлена на повышение осведомлённости граждан, эфрфективное осуществление профилактики и борьбы с наркотиками, содействие достижениям и снижение вредных последствий наркомании [27]. Среди конкретных мер можно выделить:

1. Усиление работы по распространению информации по вопросам профрилактики и борьбы с наркотиками в общинах, городах, посёлках, школах и других заведениях;

2. Осуществление образовательных программ по профилактике и борьбе с наркотиками с помощью средств массовой информации; кроме того, введение пропаганды руководящих принципов, политики и законов государства;

3. Увеличение на 5 \% количества обнаруженных преступлений, связанных с незаконным производством, торговлей, хранением и транспортировкой наркотиков;

4. Снижение количества районов, где распространены наркотики;

5. Повышение эффрективности международного сотрудничества в области профилактики и борьбы с наркотиками;

6. Сокращение площади незаконно посаженных растений и полное уничтожение всего незаконного урожая;

7. Стремление ограничить число новых наркозависимых. Для этого необходимо вести учёт, статистику и классификацию наркоманов, а также продолжать расширять формы и меры по предотвращению наркомании и снижению вреда от наркотических средств; стремиться предотвращать появление рецидивов;

8. Разработка особой модели профилактики и борьбы с наркотиками в каждой провинции, городе и деревне;

9. Возможность наркозависимым гражданам иметь доступ к услугам консультирования, лечения и дезинтоксикации [25].

Кроме внутренних мер Вьетнам также придерживается чёткой позиции на международной арене относительно необходимости профилактики и борьбы с наркопреступностью. Правительство подписало двусторонние соглашения с Камбоджей, Китаем, США, Россией, Лаосом, Мьянмой и рядом других стран в области контроля наркодеятельности на территории этих стран [11, c. 6]. Согласно различным договорам, компетентные вьетнамские органы должны осуществлять программы сотрудничества по профилактике и борьбе с наркотиками с соответствующими органами зарубежных стран, международными и иностранными организациями, а также отдельными лицами. Кроме того, Вьетнам заинтересован в сотрудничестве в сфере оказания судебной помощи в расследовании преступлений, связанных с наркотиками [20].

Правительство Вьетнама постоянно расширяет сотрудничество с международными организациями, особенно с Управлением ООН по наркотикам и преступности, а также с Интерполом [12]. Более того, Вьетнам отправляет различные делегации, которые принимают участие в конференциях и семинарах по вопросам профилактики и применения лекарственных средств, профрилактики и борьбы с наркотическими и психотропными веществами [12].

Основной партнер Вьетнама - Китай, сильно страдающий от поставки наркотиков из стран "Золотого треугольника". Китай заинтересован в борьбе с наркотиками, поэтому сотрудничество с Вьетнамом и Лаосом является одним из приоритетных для правительства. Например, странами было создано совместное Бюро пограничной связи, задача которого - координация и обмен информацией $[11$, с. 6].

Другим важным партнером Вьетнама является Сингапур. Правительство Сингапура руководствуется несколькими принципами: строгое законодательство, эффрективные меры по борьбе с наркотиками и содействие профилактическим программам. СРВ стремится перенять успешный опыт Сингапура [20].

Одним из важнейших звеньев борьбы с наркотиками является международная кооперация, а именно участие в международных конвенциях о про- 
фрилактике и борьбе с наркотическими средствами. В данный момент Вьетнам является членом трёх международных конвенций:

1. Единой конвенции о наркотических средствах 1961 г.;

2. Конвенции о психотропных веществах 1971 г.;

3. Конвенции ООН о борьбе против незаконного оборота наркотических средств и психотропных веществ 1988 г. [26].

В Единой конвенции о наркотических средствах 1961 г. прописаны основные понятия наркотических средств и их типы. Все члены конвенции признают необходимость заключения общеприемлемой международной конвенции, заменяющей уже существующие на тот момент договоры. Основными в конвенции являются следующие обязательства:

1. Введение в действие и выполнение постановлений настоящей конвенции странами-участниками в пределах их собственной территории;

2. Сотрудничество с другими государствами с целью выполнения настоящей конвенции;

3. Ограничение исключительно медицинскими и научными целями производства, изготовления, вывоза, ввоза, распределения, торговли, применения и хранения наркотических средств [8].

В Конвенции о психотропных веществах 1971 г. прописаны такие пункты, как определение веществ, которые необходимо считать психотропными, меры против злоупотребления психотропными веществами и меры против незаконного оборота психотропных веществ. В конвенции также оговаривается, что данные вещества могут производиться только по лицензии и только в научных или медицинских целях [6].

Согласно конвенции, государства-участники должны не только участвовать в предотвращении распространения, изготовления и употребления психотропных средств, но и содействовать лечению граждан на территории страны вне зависимости от их гражданства [6]. Таким образом, создаются эффективные условия борьбы с наркотическими и психотропными средствами во всем мире, а не в отдельно взятом государстве.

В Конвенции ООН о борьбе против незаконного оборота наркотических средств и психотропных веществ от 1988 г. определены общие условия взаимопомощи государств-членов. Стороны обязаны оказывать взаимную юридическую помощь, выдавать правонарушителей, обмениваться опытом, передавать материалы уголовного разбирательства и использовать другие способы сотрудничества, а также оказывать помощь в подготовке сотрудников [10].

В заключение можно отметить, что правительство Вьетнама добилось значительных успехов в сфере борьбы с выращиванием и производством наркотиков внутри страны. Однако что касается остальных вышеперечисленных осуществляемых мер, то государство ведёт недостаточно эфффективную борьбу с наркотиками в стране. Вьетнам по-прежнему остаётся перевалочным пунктом для наркоторговцев, везущих товар в Китай и другие страны региона. Вдобавок, учитывая, что с каждым годом увеличиваются как поставки наркотиков во Вьетнам, так и количество наркозависимых в этой стране, мы можем сделать вывод, что программа профилактики и борьбы с наркотиками до 2020 г. не оказала должного эффекта. Например, количество изъятых наркотиков в городе Хошимин только за первые 9 месяцев 2019 г. увеличилось на 1 102,5 \% по сравнению с 2018 г., а количество наркозависимых в городе с 2010 г. по настоящее время возросло на 15-20 \% [18]. Ещё один существенный минус - коррумпированность военных и полицейских. Облавы, контроль сухопутных и морских границ не дают успеха в борьбе с контрабандистами. Следовательно, властям Вьетнама необходимо, во-первых, провести "чистку" среди военных и полицейских, чтобы эффективно проводить профилактическую работу и борьбу с наркотиками, и, во-вторых, усилить контроль границ, в особенности с Лаосом и Камбоджой, так как именно оттуда поступает большая часть наркотических средств. Более того, необходимо вести более строгий контроль над морскими портами, которые активно использует мадрия для доставки наркотиков из Африки, Европы и Латинской Америки. И, наконец, важно проводить әффрективную пропаганду среди молодого населения и улучшать условия жизни граждан, при этом уделяя внимание и представителям национальных меньшинств, которые более склонны к торговле наркотиками.. 


\section{Литература}

1. Минина Ю. Д. Традиция чернения зубов и жевания бетеля во Вьетнаме: История, смыслы, символика / Ю. Д. Минина // Юго-Восточная Азия: Актуальные проблемы развития. 2016. № 33. С. 152-180.

2. Радько 3. Т. Анализ международной ситуации незаконного оборота наркотиков на современном этапе / З. Т. Радько, Н. В. Шигина // Вестник Университета имени О. Е. Кутафина. 2017. С. 135-154.

3. Соболева Е. С. Бетель в Южной и Юго-Восточной Азии / Е. С. Соболева // Феномен удовольствия в культуре. Матер. междунар. науч. Форума. - СПб.: Центр изучения культуры, 2004. С. 189-192.

4. Amnesty International Global Report. Death Sentences and Executions / Amnesty International. 2019. $54 \mathrm{p}$.

5. Bureau of international narcotics and law enforcement affairs. International Narcotics Control Strategy Report (INCSR) / United States Department of State. 2015. $328 \mathrm{p}$.

6. Convention on Psychotropic Substances, 1971 // UNODC. [Электронный ресурс]. URL: https://www.unodc.org/pdf/convention_1971_en.pdf (дата обращения 16.11.2019).

7. Corruption Perceptions Index 2019/ Transparency International. [Электронный pecypc]. URL: https://www.transparency.org/cpi2019 (дата обращения 07.02.2020).

8. Single Convention on Narcotic Drugs. As amended by the 1972 Protocol amending the Single Convention on Narcotic Drugs, 1961 // UNODC. [Электронный ресурc]. URL: https://www.unodc.org/pdf/convention_1961_en.pdf (дата обращения 16.11.2019).

9. Thiel, Daniel. The Illicit Drug Industry \& Counter-Narcotics in Southeast Asia // East by Southeast. [Электронный pecypc]. URL: http://www.eastbysoutheast.com/illicitdrug-industry-counter-narcotics-southeast-asia/ (дата обращения 09.11.2019).

10. United Nations Convention against Illicit Traffic in Narcotic Drugs and Psychotropic Substances, 1988 // UNODC. [Электронный ресурс]. URL: https://www. unodc.org/pdf/convention_1988_en.pdf дата обращения (16.11.2019).

11. United Nations Office on Drugs and Crime. Viet Nam Country Programme 20122017. 2012. $69 \mathrm{p}$.

12. Vietnam, Interpol fight transnational crime // The Voice of Vietnam. [Электронный pecypc]. URL: http://english.vov.vn/society/vietnam-interpol-fight-transnationalcrime-339594.vov (дата обращения 08.11.2019).

13. Windle, James. A Slow March from Social Evil to Harm Reduction: Drugs and Drug Policy in Vietnam / James Windle // Center for 21st Century Security and Intelligence Latin America Initiative. 2016. 16 p.

14. Bùi Thi Xuân Mai. Giáo trình Chất gây nghiện và Xã hội / Bùi Thi Xuân Mai // Tổ chức FHI 360, Trung tâm Dự phòng và kiểm soát bệnh tật Hoa Kì CDC, Cục phòng chống Tệ Nạn Xã họi - Bộ LĐTBXH, Trường Đại học Lao động. - Xã hội, 2013. - 140 tr. [Буи Тхи Суан Май. Йзучение веществ, вызывающих зависимость / Буи Тхи Суан Май // Организация FHI 360, Центр по контролю и профилактике заболеваний CDC, Департамент социальной защиты - Министерство труда, инвалидов и социального обеспечения, Университет труда. Ханой, 2013. 140 с.]

15. Cả nước hiện có khoảng 210 ngàn người nghiện ma túy // Báo Mới. [Электронный pecypc]. URL: http://www.ttttninhbinh.gov.vn/index.aspx?view=tin\&id=2105 [По всей стране насчитывается около 210 тысяч наркозависимых // Газета Новая.] (дата обращения 05.11.2019).

16. Hiến pháp Nước cộng hoà xã hôi chủ nghĩa Việt Nam, 1992 // Thư viện pháp luât. [Электронный pecypc]. URL: https://thuvienphapluat.vn/van-ban/bo-may-hanhchinh/Hien-phap-1992-cong-hoa-xa-hoi-chu-nghia-Viet-nam-38238.aspx [Конституция Социалистической республики Вьетнам, 1992 // Библиотека права.] (дата обращения 09.11.2019).

17. Học tập tư tưởng phòng, chống ma túy của Bác Hồ từ ngày dựng nước // Bộ Lao Đông - Thương Binh và Xã Hội. [Электронный ресурc]. URL: http://pctnxh.molisa.gov.vn/ default.aspx?page=news\&do=detail\&id=635 [Изучение идей Хошимина по предупреждению и борьбе с наркотиками с момента основания страны // Министерство труда, инвалидов и социального обеспечения.] (дата обращения 06.11.2019).

18. Hội nghị trực tuyến về thực trạng tình hình công tác phòng, chống tội phạm và vi phạm pháp luật về ma túy trên địa bàn thành phố Hồ Chí Minh // Bộ lao động - thương binh và xã hôi. [Электронный pecypc]. URL: http://pctnxh.molisa.gov.vn/default.aspx?page=n ews\&do=detail\&category_id=31\&id=2268 [Онлайн-конференция по предупреждению и борьбе с наркотиками в городе Хошимин // Министерство труда, инвалидов и социального обеспечения.] (дата обращения 16.11.2019).

19. Hội thảo báo chí về công tác cai nghiện ma túy trong tình hình mới // Bộ Lao Đông - Thương Binh và Xã Hội. [Электронный pecypc]. URL: http://pctnxh.molisa.gov.vn/ default.aspx?page=news\&do=detail\&id=1931 [Пресс-конференция о работе с наркозави- 
симыми в новой ситуации // Министерство труда, инвалидов и социального обеспечения.] (дата обращения 07.02.2020).

20. Hợp tác quốc tế phòng chống ma tuý và tình hình phòng, chống tội phạm ma tuý ở một số quốc gia // Trường đại hoc Kiểm sát Hà Nôi. [Электронный pecypc]. URL: http:// tks.edu.vn/thong-tin-khoa-hoc/chi-tiet/80/4 [Международное сотрудничество по профрилактике и борьбе с наркотиками и ситуация по продилактике и борьбе с наркотиками в некоторых странах // Ханойский прокурорский университет.] (дата обращения 07.11.2019).

21. Lạnh người cách lính Mỹ tập làm quen với cuộc chiến ở Việt Nam // Báo Mới. [Электронный ресурc]. URL: https://baomoi.com/lanh-nguoi-cach-linh-my-tap-lam-quenvoi-cuoc-chien-o-viet-nam/c/31526734.epi [Как американские солдаты адаптировались к войне во Вьетнаме // Газета Новая.] (дата обращения 07.02.2020).

22. Ma túy diễn biến phức tạp, đe dọa sự phát triển của TPHCM // Cơ quan của Tổng cuc Hai Quan. [Электронный ресурс]. URL: https://haiquanonline.com.vn/ma-tuy-dienbien-phuc-tap-de-doa-su-phat-trien-cua-tphcm-112713.html [Ситуация с наркотиками становится все сложнее, угрожая развитию города Хошимин // Агентство Главного таможенного управления.] (дата обращения 03.12.2019).

23. Nghị quyết số 01/2001/NQ-HĐTP // Thư viện pháp luật. [Электронный ресурс]. URL: https://thuvienphapluat.vn/van-ban/Trach-nhiem-hinh-su/Nghi-quyet-01-2001NQ-HDTP-huong-dan-ap-dung-quy-dinh-dieu-139-193-194-278-279-va-289-Bo-luat-hinhsu-nam-1999-47675.aspx [Постановление № 01/2001/NQ-HĐTP // Библиотека права.] (дата обращения 17.11.2019).

24. Những thách thức trong cuộc chiến chống ma túy // Báo điện tử Chính phủ Nước cộng hòa xã hội chủ nghĩa Việt Nam. [Электронный ресурc]. URL: http://baochinhphu. vn/Phap-luat/Nhung-thach-thuc-trong-cuoc-chien-chong-ma-tuy/309585.vgp [Проблемы борьбы с наркотиками // Онлайн газета правительства Социалистической Республики Вьетнам.] (дата обращения 08.11.2019).

25. Quyết địh Số: 424/QĐ-TTg. Phê duyệt chương trình phòng, chống ma túy đến năm 2020 // Thư viện pháp luật. [Электронный pecypc]. URL: https://thuvienphapluat. vn/van-ban/Van-hoa-Xa-hoi/Quyet-dinh-424-QD-TTg-Chuong-trinh-phong-chong-ma-tuyden-2020-2017-345552.aspx Постановление №: 424/QĐ-TTg. [Утверждение программы профилактики и борьбы с наркотиками до 2020 года // Библиотека права.] (дата обращения 07.11.2019).

26. Quyết định về việc nước Cộng hòa xã hội chủ nghĩa Việt Nam tham gia 3 Công ước của Liên Hợp Quốc về kiểm soát ma túy // Cơ sở dữ liệu - Thông tin điện tử của Ủy ban Quốc gia phòng, chống AIDS và phòng, chống tê nan ma túy, mai dâm. ГЭлектронный ресурс]. URL: http://tiengchuong.vn/documents/z79/item230.vgp [Постановление Социалистической республики Вьетнам об участии в 3-х международных конвенциях ОНН по контролю над наркотиками // Онлайн газета Нащионального комитета по продилактике и борьбе со СПИДом, наркотиками и проституцией.] (дата обращения 06.11.2019).

27. Thủ tướng phê duyệt chương trình phòng chống ma túy đến năm 2020 // Cơ quan của Bộ Tư Pháp cua Việt Nam. [Электронный pecypc]. URL: http://baophapluat. vn/hoi-dap-phap-luat/thu-tuong-phe-duyet-chuong-trinh-phong-chong-ma-tuy-dennam-2020-328846.html [Премьер-министр утвердил программу профилактики и борьбы с наркотиками до 2020 года // Агентство Министерства юстиции Вьетнама.] (дата обращения 06.11.2019).

28. TPHCM: Chặt đứt nnhiều đường dây, ma tuý xuyên quốc gia // Cơ sở dữ liệu - Thông tin điện tử cua Ửy ban Quốc gia phòng, chống AIDS và phòng, chống tệ nạn ma túy, mại dâm. [Электронный pecypc]. URL: http://tiengchuong.vn/Ma-tuy/TPHCM-Chat-dutnhieu-duong-day-ma-tuy-xuyen-quoc-gia/35444.vgp [Город Хошимин: Обнаружение путей поставки наркотиков через границу // Онлайн газета Национального комитета по профилактике и борьбе со СПИДом, наркотиками и проституцией.] (дата обращения $03.12 .2019)$.

29. Vén màn 'thần dược' của lính Mỹ trong chiến tranh Việt Nam // Báo Thanh Nhiên. [Электронный ресурс]. URL: https://thanhnien.vn/the-gioi/ven-man-than-duoc-cua-linhmy-trong-chien-tranh-viet-nam-692488.html [Раскрытие "панацеи" американских солдат во время вьетнамской войны // Газета Молодежь.] (дата обращения 07.02.2020).

\section{Транслитерация по ГОСТ 7.79-2000 система Б}

1. Minina Yu. D. Traditsiya cherneniya zubov i zhevaniya betelya vo V'etname: Istoriya, smysly, simvolika / Yu. D. Minina // YUgo-Vostochnaya Aziya: Aktual'nye problemy razvitiya. 2016 . № 33. S. $152-180$.

2. Rad'ko Z. T. Analiz mezhdunarodnoj situatsii nezakonnogo oborota narkotikov na sovremennom ehtape / Z. T. Rad'ko, N. V. SHigina // Vestnik Universiteta imeni O. E. Kutafina. 2017. S. 135-154. 
3. Soboleva E. S. Betel' v Yuzhnoj i YUgo-Vostochnoj Azii / E. S. Soboleva // Fenomen udovol'stviya $\mathrm{v}$ kul'ture. Mater. mezhdunar. nauch. Foruma. - SPb.: TSentr izucheniya kul'tury, 2004. S. 189-192.

4. Amnesty International Global Report. Death Sentences and Executions / Amnesty International. 2019. $54 \mathrm{p}$.

5. Bureau of international narcotics and law enforcement affairs. International Narcotics Control Strategy Report (INCSR) / United States Department of State. 2015. 328 p.

6. Convention on Psychotropic Substances, 1971 // UNODC. [Ehlektronnyj resurs]. URL: https://www.unodc.org/pdf/convention_1971_en.pdf (data obrashheniya 16.11.2019).

7. Corruption Perceptions Index 2019 / Transparency International. [Ehlektronnyj resurs]. URL: https://www.transparency.org/cpi2019 (data obrashheniya 07.02.2020).

8. Single Convention on Narcotic Drugs. As amended by the 1972 Protocol amending the Single Convention on Narcotic Drugs, 1961 // UNODC. [Ehlektronnyj resurs]. URL: https://www.unodc.org/pdf/convention_1961_en.pdf (data obrashheniya 16.11.2019).

9. Thiel, Daniel. The Illicit Drug Industry \& Counter-Narcotics in Southeast Asia // East by Southeast. [Ehlektronnyj resurs]. URL: http://www.eastbysoutheast.com/illicit-drug-industry-counter-narcotics-southeast-asia/ (data obrashheniya 09.11.2019).

10. United Nations Convention against Illicit Traffic in Narcotic Drugs and Psychotropic Substances, 1988 // UNODC. [Ehlektronnyj resurs]. URL: https://www.unodc.org/ pdf/convention_1988_en.pdf data obrashheniya (16.11.2019).

11. Unite $\bar{d}$ Nations Office on Drugs and Crime. Viet Nam Country Programme 20122017. 2012.69 p.

12. Vietnam, Interpol fight transnational crime // The Voice of Vietnam. [Ehlektronnyj resurs]. URL: http://english.vov.vn/society/vietnam-interpol-fight-transnational-crime-339594.vov (data obrashheniya 08.11.2019).

13. Windle, James. A Slow March from Social Evil to Harm Reduction: Drugs and Drug Policy in Vietnam / James Windle // Center for 21st Century Security and Intelligence Latin America Initiative. 2016. 16 p.

14. Bùi Thị Xuân Mai. Giáo trình Chất gây nghiện và Xã hội / Bùi Thị Xuân Mai // Tổ chức FHI 360, Trung tâm Dự phòng và kiểm soát bệnh tật Hoa Kì CDC, Cục phòng chống Tệ Nạn Xã hội - Bộ LĐTBXH, Trường Đại học Lao động. - Xã hội, 2013. - 140 tr. [Bui Tkhi Suan Maj. Izuchenie veshhestv, vyzyvayushhikh zavisimost' / Bui Tkhi Suan Maj// Organizatsiya FHI 360, TSentr po kontrolyu i profilaktike zabolevanij CDC, Departament sotsial'noj zashhity - Ministerstvo truda, invalidov i sotsial'nogo obespecheniya, Universitet truda. KHanoj, $2013.140 \mathrm{~s}$.

15. Cả nước hiện có khoảng 210 ngàn người nghiện ma túy // Báo Mới. [Ehlektronnyj resurs]. URL: http://www.ttttninhbinh.gov.vn/index.aspx?view=tin\&id=2105 [Po vsej strane naschityvaetsya okolo 210 tysyach narkozavisimykh // Gazeta Novaya.] (data obrashheniya 05.11.2019).

16. Hiến pháp Nước cộng hoà xã họi chủ nghĩa Việt Nam, 1992 // Thư viện pháp luật. [Ehlektronnyj resurs]. URL: https://thuvienphapluat.vn/van-ban/bo-may-hanh-chinh/ Hien-phap-1992-cong-hoa-xa-hoi-chu-nghia-Viet-nam-38238.aspx [Konstitutsiya Sotsialisticheskoj respubliki V'etnam, 1992 // Biblioteka prava.] (data obrashheniya 09.11.2019).

17. Học tập tư tưởng phòng, chống ma túy của Bác Hồ từ ngày dựng nước // Bộ Lao Động - Thương Binh và Xã Hội. [Ehlektronnyj resurs]. URL: http://pctnxh.molisa.gov.vn/ default.aspx?page $=$ news\&do=detail\&id=635 [Izuchenie idej Khoshimina po preduprezh deniyu i bor'be s narkotikami s momenta osnovaniya strany // Ministerstvo truda, invalidov i sotsial'nogo obespecheniya.] (data obrashheniya 06.11.2019).

18. Hội nghị trực tuyến về thực trạng tình hình công tác phòng, chống tội phạm và vi phạm pháp luật về ma túy trên địa bàn thành phố Hồ Chí Minh // Bộ lao động - thương binh và xã hôi. [Ehlektronnyj resurs]. URL: http://pctnxh.molisa.gov.vn/default.aspx?page $=$ news\&do=detail\&category_id $=31 \& i d=2268$ [Onlajn-konferentsiya po preduprezh deniyu i bor'be s narkotikami v gorode Khoshimin // Ministerstvo truda, invalidov i sotsial'nogo obespecheniya.] (data obrashheniya 16.11.2019).

19. Hội thảo báo chí về công tác cai nghiện ma túy trong tình hình mới // Bộ Lao Đông - Thương Binh và Xã Hôi. [Ehlektronnyj resurs]. URL: http://pctnxh.molisa.gov.vn/ default.aspx?page=news\&do=detail\&id=1931 [Press-konferentsiya o rabote s narkozavisimymi v novoj situatsii // Ministerstvo truda, invalidov i sotsial'nogo obespecheniya.] (data obrashheniya 07.02.2020).

20. Hợp tác quốc tế phòng chống ma tuý và tình hình phòng, chống tội phạm ma tuý ở một số quốc gia // Trường đại hoc Kiểm sát Hà Nội. [Ehlektronnyj resurs]. URL: http://tks. edu.vn/thong-tin-khoa-hoc/chi-tiet/80/4 [Mezhdunarodnoe sotrudnichestvo po profilaktike i bor'be s narkotikami i situatsiya po profilaktike i bor'be s narkotikami v nekotorykh stranakh // KHanojskij prokurorskij universitet.] (data obrashheniya 07.11.2019).

21. Lạnh người cách lính Mỹ tập làm quen với cuộc chiến ở Việt Nam // Báo Mới. [Ehlektronnyj resurs]. URL: https://baomoi.com/lanh-nguoi-cach-linh-my-tap-lam-quen-voi- 
cuoc-chien-o-viet-nam/c/31526734.epi [Kak amerikanskie soldaty adaptirovalis' k vojne vo V'etname // Gazeta Novaya.] (data obrashheniya 07.02.2020).

22. Ma túy diễn biến phức tạp, đe dọa sự phát triển của TPHCM // Cơ quan của Tổng cuc Hai Quan. [Ehlektronnyj resurs]. URL: https://haiquanonline.com.vn/ma-tuy-dienbien-phuc-tap-de-doa-su-phat-trien-cua-tphcm-112713.html [Situatsiya s narkotikami stanovitsya vse slozhnee, ugrozhaya razvitiyu goroda Khoshimin // Agentstvo Glavnogo tamozhennogo upravleniya.] (data obrashheniya 03.12.2019).

23. Nghi quyết số 01/2001/NQ-HĐTP // Thư viện pháp luật. [Ehlektronnyj resurs]. URL: https://thuvienphapluat.vn/van-ban/Trach-nhiem-hinh-su/Nghi-quyet-01-2001-NQHDTP-huong-dan-ap-dung-quy-dinh-dieu-139-193-194-278-279-va-289-Bo-luat-hinh-sunam-1999-47675.aspx [Postanovlenie № 01/2001/NQ-HĐTP // Biblioteka prava.] (data obrashheniya 17.11.2019).

24. Những thách thức trong cuộc chiến chống ma túy // Báo điện tử Chính phủ Nước công hòa xã hôi chủ nghĩa Việt Nam. [Ehlektronnyj resurs]. URL: http://baochinhphu. vn/Phap-luat/Nhung-thach-thuc-trong-cuoc-chien-chong-ma-tuy/309585.vgp [Problemy bor'by s narkotikami // Onlajn gazeta pravitel'stva Sotsialisticheskoj Respubliki V'etnam.] (data obrashheniya 08.11.2019).

25. Quyết định Số: 424/QĐ-TTg. Phê duyệt chương trình phòng, chống ma túy đến năm 2020 // Thư viện pháp luật. [Ehlektronnyj resurs]. URL: https://thuvienphapluat. $\mathrm{vn} / \mathrm{van}$-ban/Van-hoa-Xa-hoi/Quyet-dinh-424-QD-TTg-Chuong-trinh-phong-chong-ma-tuyden-2020-2017-345552.aspx [Postanovlenie №: 424/QĐ-TTg. Utverzhdenie programmy profilaktiki i bor'by s narkotikami do 2020 goda // Biblioteka prava.] (data obrashheniya 07.11.2019).

26. Quyết định về việc nước Cộng hòa xã hội chủ nghĩa Việt Nam tham gia 3 Công ước của Liên Hợp Quốc về kiểm soát ma túy // Cơ sở dữ liệu - Thông tin điện tử của Ưy ban Quốc gia phòng, chống AIDS và phòng, chống tệ nạn ma túy, mại dâm. [Ehlektronnyj resurs]. URL: http://tiengchuong.vn/documents/z79/item230.vgp [Postanovlenie Sotsialisticheskoj respubliki V'etnam ob uchastii v 3-kh mezhdunarodnykh konventsiyakh ONN po kontrolyu nad narkotikami // Onlajn gazeta Natsional'nogo komiteta po profilaktike i bor'be so SPIDom, narkotikami i prostitutsiej.] (data obrashheniya 06.11.2019).

27. Thủ tướng phê duyệt chương trình phòng chống ma túy đến năm $2020 / /$ Cơ quan cưa Bộ Tư Pháp cua Việt Nam. [Ehlektronnyj resurs]. URL: http://baophapluat.vn/hoi-dap-phap-luat/thu-tuong-phe-duyet-chuong-trinh-phong-chong-ma-tuy-dennam-2020-328846.html [Prem'er-ministr utverdil programmu profilaktiki i bor'by s narkotikami do 2020 goda // Agentstvo Ministerstva yustitsii V'etnama.] (data obrashheniya 06.11.2019).

28. TPHCM: Chặt đứt nhiều đường dây ma tuý xuyên quốc gia // Cơ sở dữ liệu - Thông tin điền tử của Ửy ban Quốc gia phòng, chống AIDS và phòng, chống tệ nạn ma túy, mại dâm. [Ehlektronnyj resurs]. URL: http://tiengchuong.vn/Ma-tuy/TPHCM-Chat-dut-nhieuduong-day-ma-tuy-xuyen-quoc-gia/35444.vgp [Gorod KHoshimin: Obnaruzhenie putej postavki narkotikov cherez granitsu // Onlajn gazeta Natsional'nogo komiteta po profilaktike i bor'be so SPIDom, narkotikami i prostitutsiej.] (data obrashheniya 03.12.2019).

29. Vén màn 'thần dược' của lính Mỹ trong chiến tranh Việt Nam // Báo Thanh Nhiên. [Ehlektronnyj resurs]. URL: https://thanhnien.vn/the-gioi/ven-man-than-duoc-cua-linhmy-trong-chien-tranh-viet-nam-692488.html [Raskrytie "panatsei" amerikanskikh soldat vo vremya v'etnamskoj vojny // Gazeta Molodezh'.] (data obrashheniya 07.02.2020). 


\section{Ильин В. Е. Опыт Вьетнама по борьбе снаркотиками.}

Статья описывает проблему предупреждения и борьбы с наркотиками во Вьетнаме. Вьетнам граничит со странами "Золотого треугольника" и является транзитным пунктом перевозки наркотических и психотропных веществ из Мьянмы, Лаоса, Таиланда и Камбоджи в Китай и другие страны Северо-Восточной Азии. Распространение наркотиков создаёт угрозу не только для Вьетнама, но и для всех стран Юго-Восточной и Северо-Восточной Азии, что связано, во-первых, с ежегодным ростом производства и сбыта наркотических средств на азиатских рынках, а во-вторых, с высоким спросом на тяжёлые виды наркотиков, например, на героин, в этих странах.

Ключевые слова: Вьетнам, предупреждение и борьба с наркотиками, наркотические и психотропнье вещества, Юго-Восточная Азия, Северо-Восточная Азия

\section{Iliyn V. E. Drug prevention and control in Vietnam.}

The article describes the problem of drug prevention and control in Vietnam. Vietnam borders the countries of the "Golden triangle" and is a transit point for the transport of narcotic and psychotropic substances from Myanmar, Laos, Thailand and Cambodia to China and other countries of Northeast Asia. This problem poses a threat not only to Vietnam, but also to all countries of Southeast and Northeast Asia, that is associated, firstly, with the annual increase in the production and distribution of drugs in Asian markets, and secondly, with the high demand for hard drugs, for example heroin, in these countries.

Key words: Vietnam, drug prevention and control, narcotic and psychotropic substances, Southeast Asia, Northeast Asia

Для цитирования: Ильин В. Е. Опыт Вьетнама по борьбе снаркотиками // Ойкумена. Регионоведческие исследования. 2020. № 1. C. 112-122. DOI: 10.24866/1998-6785/2020-1/112122

For citation: Iliyn V. E. Drug prevention and control in Vietnam // Ojkumena. Regional researches. 2020. № 1. P. 112-122. DOI: 10.24866/1998-6785/2020-1/112-122 


\section{"Мягкая сила" во внешней политике России и Китая: особенности национальных стратегий}

В современных реалиях, где глобализация способствует постоянному изменению и подталкивает к действиям, государствам на мировой арене особенно важно найти новые рычаги давления и влияния. Одним из таких рычагов является "мягкая сила" - прямое противопоставление "жёсткой силе", которая главенствовала последние столетия. Сравнительно недавно появившийся феномен "мягкой силы" порой уже является ключевым в реализации внешней политики. Россия и Китай активно используют инструментарий "мягкой силы" в своей внешней политике, что актуализирует изучение вопроса эфрфективности использования данного инструментария в сравнительном аспекте.

Целью данной работы является анализ и оценка эфффективности инструментов "мягкой силы", которые Россия и Китай используют в рамках своей внешней политики.

Проблематика использования инструментария "мягкой силы" в международной политике широко представлена в исследованиях российских авторов и китайских ученых. Среди российских авторов можно отметить работы А. Бобыло, А. Казанцевой, С. Кухаренко, М. Ларионовой, М. Лебедевой, В. Меркушина, П. Паршина, А. Сухарева, Г. Филимонова и др. Китайские ученые также не обошли своим вниманием вопросы инструментария "мягкой силы" во внешней политике КНР и эффективности его использования на практике (Ван Сяоюн, Ван Хунин, Лу Ган, Лю Цзайци, Пан Чжунъин, Юй Синьтянь, Янь Сюэтун и др.). Большая часть китайских авторов сходится во мнении, что именно культура является основой "мягкой силы" современного китайского государства, т. е. их работы выполнены в рамках культурно-цивилизационного подхода (например, исследования директора Бюро исследований политики ЦК профрессора Ван Хунин или члена Шанхайской академии общественных наук Юй Синьтянь). Работы же профессора престижного в Китае университета Цинхуа Янь Сюэтуна выполнены в рамках политологического подхода, где "мягкая сила" рассматривается в качестве политического инструмента по продвижению не только китайской культуры, но и привлекательности китайской государственной модели, политических институтов. Обозначенные научные подходы составили методологическую основу данного исследования.

Определение "soft power" или, как ее называют у нас, "мягкой силы" было дано американским политологом Джозедом Наем. "Мягкая сила" фрактически является "способностью международного актора достичь желаемых результатов методом убеждения, а не методом принуждения или подавления, что характерно для "жёсткой силы". "Мягкая сила" действует, притягивая других следовать правилам игры в международных отношениях, стремится к достижению желаемых результатов без принуждения" [37, p. 21].

Несмотря на то, что данный термин возник применительно к политике американского государства, три ключевых компонента, составленных Джозефом Наем, являются актуальными и для других государств. Среди них:

\section{(C) Владимирова Д. А., Журбей Е. В., Карловскал А. А., 2020}

ВЛАДИМИРОВА Диана Альбертовна, канд. ист. наук, профессор кафедры Тихоокеанской Азии Дальневосточного федерального университета (е. Владивосток). E-mail: vkadimirova.da@, dvfu.ru

ЖУРБЕЙ Евгений Викторович, канд. ист. наук, доцент кафедры Тихоокеанской Азии Дальневосточного фредерального университета (2. Владивосток). E-mail: zhurbey.ev@dvfu.ru

КАРЛОВСКАЯ Анастасия Андреевна, студентка Дальневосточного федерального университета (2. Владивосток). E-mail: anastasiya_karlovskaya@mail.ru 
привлекательность культуры и образа жизни; принципы и ценности политической системы; дипломатические усилия по разрешению политических кризисов и конфликтов. Эти компоненты, представляющие собой культуру, идеологию и политические институты, способны убеждать других "захотеть того, чего хочешь ты" [38, p. 31].

Примеров, характеризующих каждый из компонентов, существует великое множество. Так, к культуре можно отнести язык, искусство, деятельность СМИ, спорт или туризм; политические институты включают в себя свободу, демократию во всех ее проявлениях и права человека; сюда также относятся мода, технологии, мировые бренды и многое другое.

Анализ "мягкой силы" России и КНР действительно актуален, так как, например, Россию в 2016 году впервые включили в ежегодный рейтинг, подготовленный центром Публичной дипломатии Университета Южной Калифорнии и PR-агентством Portland, "The Soft Power 30", где она заняла 27 позицию, а Китай - 28 [39]. Спустя два года Россия заняла в данном списке 28 место, а Китаю уступила 27 [39]. Стоит отметить, что рейтинг каждой страны формируется из следующих характеристик: предпринимательство, культура (куда входит спорт), образование, государственное управление, џифровые технологии и глобальное влияние.

"Мягкая сила" как явление в России не нова: впервые о ней заговорил на высшем уровне министр иностранных дел С. В. Лавров в 2008 г. в интервью для "Российской газеты" [17]. В 2012 г. президент РФ В. В. Путин, выступая на совещании послов и постпредов РФ в Москве, также выступил с идеей о разработке новых технологических подходов к международной работе, которые основывались бы на "мягкой силе". Спустя короткий промежуток времени, в 2013 г., "мягкая сила" добавлена в Концепцию внешней политики России как "комплексный инструментарий решения внешнеполитических задач с опорой на возможности гражданского общества, информационно-коммуникационные, гуманитарные и другие альтернативные классической дипломатии методы и технологии" [11]. В данную концепцию также входит цель, напрямую связанная с наращиванием "мягкой силы": "распространение и укрепление позиций русского языка в мире, популяризация культурных достижений народов России, консолидация русской диаспоры за рубежом" [11].

Так, например, на встрече с личным советником В. Толстым, В. В. Путин заявил: "Нам очень важно создать культурное пространство". Культура должна стать главной объединяющей субстанцией нации, сыграть консолидирующую, объединяющую роль [25]. Си Цзиньпин, в свою очередь, сказал: "История показывает, что только путем обмена и взаимного обучения цивилизация может наполниться жизненной силой. Если все цивилизации будут поощрять инклюзивность, о так называемом "столкновении цивилизаций" не может быть и речи, а гармония цивилизаций станет действительностью" [24].

Отметим тот фракт, что китайское правительство уже давно определило один из векторов своего направления "мягкой силы". Этим вектором является культура: официально термин используется как "软实力" (ruan shi li / жуань ши ли) и добавляется префикс-слово "文化"(wen hua / вэнь хуа - культура). Помимо "традищионной культуры", "мягкая сила" в Китае также коррелируется с терминами: "экономическая модель развития", "национальное единство", "социальная справедливость", "политическая реформа", "моральные нормы" и другими. [28, с. 181]. Однако, так как "мягкая сила" все же является политикой, китайские ученые встали перед вопросом о том, что важнее для государственной деятельности: "мягкая сила культуры" или "мягкая сила политики". Мнения разделились, что способствовало образованию двух направлений исследования термина - в культурном и политическом ключе [3, с. 55, 76].

На самом деле, теория "мягкой силы" в Китае разработана еще задолго до ее официального появления. Открытие данного френомена было сделано китайскими философами Лао Цзы, Конфуцием и Сунь Цзы и тогда активно применялось в военной стратегии и политике [22, с. 49]. Еще задолго до принятия термина "мягкая сила" в государственной политике КНР, были опубликованы работы профрессора Фуданьского университета Ван Хунина, который четко определил роль культуры как национальной силы, имеющей мягкое и последовательное воздействие на окружающий мир [42]. Вторит ему и профрессор ведущего вуза КНР, кузницы партийных лидеров - университе- 
та Цинхуа, Янь Сюэтун. Ссылкой на политического деятеля периода Чуньцю Гуань Чжуна, Янь Сюэтун ещё раз подчеркивает, что "политика мягкой силы способна наладить отношения и взаимодоверие с соседними странами" [43].

На современном этапе политика "мягкой силы" КНР была озвучена Ху Цзиньтао в ходе XVII съезда КПК в 2007 году и с тех пор включена в партийную идеологию. Он заявил, что данная концепция должна посодействовать созданию "гармоничного общества" в Китае и "гармоничного мира" за его пределами [7]. На следующем, XVIII съезде в 2012 г., отдельно выделена задача "усиления роли культуры как "мягкой силы" государства". Помимо прочего, в доклад были включены цели по повышению культурного уровня граждан и образованности общества, необходимости активного содействия распространению китайской культуры за рубежом [33]. Председатель Си Цзиньпин в январе 2014 г., выступая с речью перед членами Политбюро КПК, призвал к развитию мягкой силы для создания национального имиджа Китая, распространения современных китайских ценностей и демонстрации обаяния китайской культуры всему миру. За заявлениями последовала обширная программа продвижения Китая в мире. Китай использовал различные инструменты для улучшения своих возможностей мягкой силы.

\section{Образование}

В Китае в качестве средств достижения этих задач особо выделяются образование, знание языка и Институты Конфуция. Например, на сайте Института Конфуция заявлена миссия распространения китайского языка и культуры во всем мире, содействия развитию мультикультурализма и построению гармоничного мира [2, с. 233-234]. Отделения Института Конфуция образуются во всех уголках мира при условии того, что есть вуз-партнер с китайской стороны. Специалисты-китаисты в свою очередь помогают в достижении данной цели в тех странах, где организованы Институты. Так, на 2018 год количество Институтов Конфуция составляло 548 офисов в 154 городах мира, а также 1193 класса Конфуция в общеобразовательных школах. В странах Азии, например, расположено 126 офисов и 114 классов Конфуция, в странах Европы - 182 офиса и 341 класс соответственно [2, с. 233-234].

Популяризация китайского языка посредством Институтов Конфуция успешно осуществляет политику "мягкой силы" КНР. В России китайский язык особо популярен, и теперь у выпускников школ есть возможность сдать ЕГЭ по китайскому языку и 289 школьников сделали выбор в его пользу [26].

Власти Китая осознают, что для того, чтобы подготовить высококвалифицированные кадры, мало задействовать собственные силы, необходимы специалисты из-за рубежа. Здесь появляется стратегия "привлечения зарубежного". К ней можно отнести реализацию в Китае программ подготовки бакалавров, магистрантов и докторов наук, что привлекает студентов со всего мира. Достаточно высокая стипендия от 1300 до 3000 юаней, возможность получить грант на обучение и полное обеспечение при университете, а также высокий уровень преподавания являются ключевыми моментами при выборе китайского образования. В итоге, после четырехлетнего и более длительного обучения, студенты сами становятся распространителями "мягкой силы" КНР $[1$, c. 7$]$.

По словам Министра науки и высшего образования Российской Федерации М. М. Котюкова, количество китайских студентов в 2018 г. достигло 30 тысяч человек, что больше на 10\% по сравнению с 2016-2017 учебным годом [5]. Число высших учебных заведений, где обучаются китайские студенты, составило 85 по всей России. Выбираются не только столичные вузы, но и дальневосточные. Так, на базе ДВФУ основано 12 языковых центров для изучения русского языка, семь из которых фрункционируют непосредственно при университете, а остальные распределены между колледжами и средними школами. Общее количество студентов во всех центрах достигает 450 тысяч человек в год. Значительный прирост обучающихся в России эксперты связывают со стратегией "Один пояс - один путь", где РФ играет существенную роль, являясь социально-экономическим и политическим партнером Китая.

Китайские студенты в университетах преимущественно выбирают следующие направления: социально-гуманитарные, экономику и управление, некоторые инженерные специальности и непосредственно сам русский язык и 
все, что связано с ним (литературоведение, языкознание и т. д.). Выбор специальностей для обучения в магистратуре или аспирантуре в большинстве случаев тот же, хотя некоторые могут продолжить обучение в области педагогики или искусства.

На данный момент Россия и Китай активно занимаются разработкой совместных образовательных программ, связанных с изучением русского и китайского, а также направленных на инновационное развитие. Список университетов, на базе которых проводится обучение, многообразен: СПбГУ, ДВФУ, РУДН, а также более шестисот китайских университетов, включая Южнокитайский политихнический университет, Восточнокитайский педагогический университет и другие. Сегодня подписано более 900 совместных договоров, созданы профильные ассоциации российских и китайских университетов [5].

В России сегодня ответственным за образование является Министерство науки и высшего образования РФ, а на международном уровне - Министерство иностранных дел РФ. За рубежом активным продвижением русской культуры и языка занимаются российские центры науки и культуры (РЦНК), которые расположены более чем в 70 странах мира, включая Китай, Францию, США и многие другие государства. Деятельность РЦНК осуществляется по направлениям поддержки соотечественников, информационного сопровождения внешней и внутренней политики РФ, взаимодействия с НПО и другими областями.

Наибольшую значимость сегодня имеют программы сотрудничества с молодежью. В рамках Стратегии государственной молодежной политики РФ и Стратегии международного молодежного сотрудничества государств-участников СНГ на период до 2020 г. Министерство иностранных дел способствует получению высшего образования в России. Иностранная молодежь посещает в РФ всевозможные форумы, например, "Балтийский Артек" или "Селигер".

По проекту "Образование" в РФ государственные власти рассчитывают привлечь около 425 тысяч иностранных студентов (что в два раза выше, чем на сегодняшний день) к 2024 г. [19]. Данный нацпроект в период с 2019 по 2024 г. нацелен не только на то, чтобы улучшить качество образования, но и сделать его конкурентоспособным и продвинуть государство в десятку ведущих стран по качеству высшего образования.

Культурные обмены увеличиваются преимущественно с постсоветскими государствами. Российская система высшего образования по-прежнему привлекательна для студентов из бывших советских республик, потому что лучшие российские университеты в Москве, Санкт-Петербурге и некоторых других городах по-прежнему могут обеспечить иностранным студентам хорошую подготовку в области точных и гуманитарных наук.

В 2007 г. указом президента был создан Фонд "Русский мир" (хотя он и имеет статус НПО). Основная функция Фонда - продвижение русского языка, культуры и системы образования за рубежом. Идеологический фон и авторство названия "Русский мир" часто приписывают Петру Щедровицкому. Он утверждал: "В XX веке в результате тектонических исторических сдвигов, мировых войн и революций появился Русский Мир как сетевая структура больших и малых сообществ, которые думают и говорят на русском языке" [31, c. 374]. Русский мир, основанный на культурных и коммуникационных ресурсах русского языка, затем интерпретируется как подспорье "мягкой силы", которое можно использовать для определения повестки дня и укрепления устойчивости государственности. Например, "Русский мир" номинирует лучших преподавателей и студентов по русскому языку и культуре на должность "профессора русского мира" и "студента русского мира". Он также предлагает программы стажировок для иностранных ученых и студентов из России. Фонд регулярно проводит различные конференции, конкурсы и олимпиады. В 2008 г. было создано Россотрудничество, Федеральное агентство по делам СНГ ("Соотечественники за рубежом" и "Международное гуманитарное сотрудничество") с почти той же миссией, что и "Русский мир", но со статусом представительства при Министерстве иностранных дел. Бывший Президент РФ Д. А. Медведев сказал: "Россотрудничество должно стать одним из ключевых инструментов так называемой "мягкой силы"" [6]. На сегодняшний день агентство имеет представительства практически во всех европейских странах: США, Канаде и крупных странах Азии, Африки и Латинской Амери- 
ки. В дополнение к этим двум основным учреждениям, ряд НПО, например, Фонд общественной дипломатии им. Горчакова, Фонд Андрея Первозванного, Международные фонды по работе с диаспорами за рубежом "Россияне", Международный совет соотечественников России, Библиотека "Русскоязычная литература за рубежом" и Международная ассоциация городов-побратимов участвуют в мероприятиях по "мягкой силе".

Москва и Пекин придают огромное значение двустороннему образованию. "Мягкая сила" позволяет наращивать обмен знаниями между странами, a их отношения переходят на более высокий уровень, так как реализуются взаимные интересы. В дальнейшем, благодаря этому направлению реализации "мягкой силы", объединившись, страны смогут оказать "мягкое" влияние на другие державы.

В современном мире именно у образования есть силы и рычаги воздействия на общественность, оно является одним из важнейших направлений "мягкой силы". Осознав возможности влияния образования, и Китай, и Россия осуществляют данную политику с целью привлечения иностранных студентов, чтобы в конечном итоге приобрести возможность влиять на мировые тенденции.

\section{Средства массовой информации}

В настоящее время лидерами мнений являются преимущественно европейские и американские средства массовой информации. По этой причине, руководство Китая приняло решение не только изменить свой подход по отношению к зарубежным СМИ, но и создать новые возможности для граждан других стран узнавать новости о КНР из альтернативных источников.

Китайские аналитики Цзян Сяоли и Ли Цзяньхуа в своей работе обозначили, что "мягкая сила культуры является ядром мягкого воздействия страны, а средства массовой информации являются не только носителем и "боевой мощью" распространения культуры, но и ключевым компонентом самой мягкой силы культуры" [44].

Важную роль в медиапространстве Китая занимает Информационное бюро Госсовета КНР. Бюро не только получает новостную информацию, но и занимается выпуском книг, журналов, кинофильмов, содействует ознакомлению местного населения с медиапродуктами. Прежде всего это делается для Тайваня, Гонконга и китайских диаспор за рубежом, которые руководство Китая хотело бы ввести в курс обстановки в стране в первую очередь. Немаловажно ознакомить зарубежных граждан с политической и не только обстановкой в КНР, приобщить к культуре. Осуществляется это при помощи издательства Foreign Languages Press, газет China Daily и Global Times [38, p. 101] и многочисленных интернет-ресурсов, которые координирует Информационное бюро.

В попытке укрепиться в мировом сообществе, Китай формирует медиаландшафт, увеличивая ресурсы "мягкой силы". Например, Центральное телевидение Китая (CCTV), Международное радио Китая (CRI), информационное агентство (ИА) "Синьхуа" и газета "Жэньминь Жибао" направлены на то, чтобы создать образ Китая, а также мировых новостей, отличных от тех, которые представляют зарубежные СМИ. Таким образом, правительство показывает свое видение ситуащий, происходящих внутри страны и на мировой арене, а благодаря огромному многообразию языков, на которых происходит вещание, влияние оказывается на широкие массы [41, p. 84]. В частности, CCTV круглосуточно транслирует новости на английском, фрранцузском, русском и нескольких других языках.

Помимо прочего, создаются мобильные приложения для ознакомления с новостями, сайты, публикуется видео- и фотоконтент, развивая медиапространство в интернете, что, в свою очередь, помогает китайским СМИ противостоять западным.

При помощи развития СМИ Пекин старается не только улучшить свое положение в мире, но и создать благоприятный образ среди иностранных государств при помощи "мягкой силы". Несмотря на то, что СМИ являются только государственной прерогативой, медиавлияние Китая на зарубежных граждан значительно повысилось. 
Россия также стремится к развитию медиапространства для улучшения собственного имиджа в мире. Еще в 2000 г., в Послании Президента Российской Федерации Федеральному Собранию было отмечено следующее: "Важным направлением внешнеполитической деятельности должно стать содействие объективному восприятию России. Достоверная информация о событиях в нашей стране - это сегодня вопрос и ее репутации, и национальной безопасности" [23].

В настоящее время российские государственные СМИ нацелены на передачу новостей за рубеж, а также уменьшение влияния западных конкурентов. Созданный в 2005 г. по инициативе В. В. Путина канал Russia Today сегодня продвигает взгляды правительства, новости государства. В условиях глобализации разрабатываются новые коммуникационные стратегии для повышения эффективности инструментария российской "мягкой силы". Канал запустили с целью донести до англоязычной аудитории российскую точку зрения по основным мировым событиям. Вещание RT сегодня осуществляется больше чем в 100 странах. Однако в последние годы новостной портал RT активно критикуется западными СМИ, и даже создаются ограничения по его распространению в ряде стран, так как ресурс воспринимается как угроза, как источник искаженной информации.

В 2007 г. был запущен еще один проект - Russia Beyond the Headlines. Этот проект создан для публикации российских приложений в ведущих изданиях западных стран. В 2013 г. Указом Президента РФ было создано Международное информационное агентство "Россия сегодня", а спустя год на его базе открылась мультимедийная группа "Спутник" [12, с. 681].

\section{Спорт}

Если еще недавно считалось, что спорт не относится к политической жизни и не оказывает никакого влияния на массы, то сейчас фракт причастности отрицать невозможно. По мнению Г. Люшена, победы спортсменов неотделимы от политики и, соответственно, применяются для достижения политических целей $[14$, с. 138].

Не секрет, что спортивные успехи имеют прямую связь и с экономической политикой, и с политической ситуацией внутри страны, а спортивные победы прибавляют статус и узнаваемость государству. Китай и Россия на протяжении долгих лет успешно развивают спорт, однако первому удалось сделать то, чего Россия еще не достигла: Китай развивает спорт при помощи капиталистических методов. На социальной сфере отражаются любые спортивные мероприятия, но особенно отзываются те, из которых страна выходит победителем.

Благодаря редормам Дэн Сяопина в 80-е гг. XX в., правительство поставило цель - вырваться вперед в олимпийских видах спорта. Китай намеренно выбрал тактику подготовки к низкоконкурентным видам спорта и тем видам, где было возможно выиграть наибольшее количество медалей. Благодаря этому во время Олимпийских игр 2008 г. в Пекине китайские спортсмены завоевали 100 медалей и набрали наибольшее количество золотых - 51. Китай с уверенностью закрыл любые допинговые программы, построил антидопинговую лабораторию.

Спортивные центры Китая успешно справляются с подготовкой молодых спортсменов, но немногие могут туда попасть. Лишь имея выдающиеся способности, спортсмены завоевывают право становиться лучшими в этой области. Благодаря активной пропаганде спорта, фринансированию со стороны государства и значительным успехам в данной области, в Китае уже к концу 90-х годов XX в. проживало наибольшее количество спортсменов в мире. Инвестищии в спорт способствуют тому, что в стране отстраиваются самые лучшие спортивные центры, например, спорткомплекс по водным видам спорта в Шанхае. Китай является отличным примером спортивной нации: состоит более чем в 100 международных спортивных ассоциациях, сотрудничает со 150 странами на спортивной основе, принимает на своей территории всевозможные азиатские соревнования, Олимпийские игры и даже Формулу-1 [4, c. 54].

В России, в свою очередь, также ведется пропаганда здорового образа жизни, выделяются огромные средства на строительства международных 
спортивных комплексов ("Лужники", "Олимпийский" в Москве, огромное количество комплексов в Сочи, построенных по случаю проведения Олимпийских игр, арена "Ерофей" в Хабаровске и многие другие). Цель России - объединить страну спортом, поддержать товарищеский дух, патриотизм, развить новое мышление. Не секрет, что президент РФ В. В. Путин является спортивным человеком, это уже поддерживает спортивный дух в стране, подает положительный пример населению.

Важную роль в области спорта имели Олимпийские игры в Сочи 2014 г., благодаря которым туристы смогли больше узнать о культурных особенностях России, ее благоустройстве. Возможно, этому также поспособствовало то, что Олимпийские игры в Сочи стали самыми дорогостоящими в истории (финансирование составило 50 млрд долл. США), а после них - игры в Пекине (40 млрд долл. США) [20].

Старания России оправдались, так как страна завоевала 33 медали: 13 золотых, 11 серебряных и 9 бронзовых, заняв благодаря этому первое место в неофициальном командном зачете. В параолимпийских играх спортсмены также преуспели, выиграв 30 золотых, 28 серебряных и 22 бронзовых медали. Это был рекорд в неофициальном медальном зачете.

Олимпийские игры повысили статус России на международной арене, привлекли огромное количество туристов и иностранных инвестиций в развитие страны. Спорт можно считать одним из перспективных направлений "мягкой силы" РФ, это особенно актуально в последнее время, когда создается большое количество спортивных площадок и вкладываются средства в спортивные мероприятия, особенно проводимые на международном уровне. Помимо упомянутых Олимпийских игр, сюда можно отнести Чемпионат мира по легкой атлетике 2013 г., Чемпионат мира по водным видам спорта в 2015 г., Чемпионат мира по футболу в 2018 г..

Но, хотя Россия и обладает значительными ресурсами в области спорта, политика "мягкой силы" здесь реализуется не так успешно, как, например, в Китае. В РФ все еще отсутствует четкая система использования "мягкой силы", работе в этой сфере не хватает продуманности и единства. Безусловно, на территории страны были организованы международные мероприятия, но это скорее единичные случаи, ведь в России нет единого центра, который бы контролировал траты и планы [18]. У правительства отсутствуют "качественные" контакты с НПО, гражданским обществом или представителями СМИ. Это отражается на имидже Москвы, ведь СМИ располагают силой, способной его улучшить, но порой получается наоборот - у России роль скорее негативного персонажа, нежели позитивного [18]. Сюда можно отнести "мельдониевую войну" и допинговые скандалы, которые показали непродуктивность спортивных чиновников.

Так как "спортивная дипломатия" появилась сравнительно недавно, Россия находится только в процессе ее разработки, и события, связанные с отстранением российских олимпийцев, показывают ее низкую эфрфективность. Успешно проведенные Олимпийские Игры 2014 г. в Сочи позволили иностранным журналистам отметить не только их качественную организацию, но и роль инструмента, отвлекающего от конфликта с Украиной. Тогда государству удалось не только провести запоминающееся спортивное мероприятие, но и получить необходимое время для принятия верного решения [8].

\section{Туризм}

Туризм также считается перспективным направлением для развития "мягкой силы". Туризм повышает международный имидж страны, что для Китая крайне актуально - за 2018 г. его посетили 30,5 миллионов иностранных туристов и потратили там более 73 миллиардов долларов [9]. Основными туристами, посетившими Китай за прошлый год, стали граждане Малайзии, Сингапура, Южной Кореи, Японии. Хотя Олимпийские Игры прошли еще в 2008 г., Китай продолжает получать от этого события определенные дивиденды, равно как и от участия в ЭКСПО-2010. Пекин также выиграл заявку на проведение зимних Олимпийских игр 2022 г. [32], и данное событие, безусловно, поспособствует развитию "мягкой силы", а также привлечет в страну огромный турпоток спортивных болельщиков и обывателей. Благодаря экономическому росту, сами китайские туристы предпочитают посещать в послед- 
нее время Таиланд, Южную Корею, Филиппины [35], помимо того, что путешествуют внутри своей страны. Существует мнение, что более важную роль здесь имеют те суммы, которые китайские туристы тратят в путешествиях. Чем больше суммы - тем престижнее, дороже, вычурнее становится отдых, и тем, соответственно, более респектабельно выглядит сам Китай, а с экономической точки зрения это повышает "мягкую силу" [15, с. 99].

Ли Хуэй, Чрезвычайный и Полномочный Посол КНР в РФ, выступая на Минвостокразвития РФ, сказал: "За 2017 год количество китайских туристов в России достигло 1,5 млн. Это наибольшая доля среди всех стран мира для России. А Китай, в свою очередь, занял второе место среди стран, куда приезжают русские туристы" [10]. Отдельно хотелось бы отметить положительные изменения в Приморском крае. С 2017 г. турпоток в регион увеличился настолько, что уступает свое место лишь Москве, здесь открыто 32 туристических маршрута для туристов, а также действует электронная виза - она значительно упрощает въезд на территорию края.

Между правительствами было подписано несколько соглашений в туристической сфрере: Меморандум о сотрудничестве между российской ассоциацией "Мир без границ" и Китайской ассоциацией туристических компаний в 2007 г., "Программа сотрудничества между регионами и Восточной Сибири РФ и Северо-Востока КНР" с 2009 по 2018 г.. Последняя включала в себя ряд планов и перспектив в области турпотока и рассматривала ряд мероприятий $[16$, c. 110]:

1. создание в приграничных районах маршрутов российско-китайской дружбы по центральным городам на Востоке России и Китая;

2. проведение международных туристских форумов в пограничных городах двух стран;

3. организацию туристических маршрутов по российско-китайским пограничным рекам и других совместных трансграничных туристических маршрутов.

Туризм со стороны Китая в Россию также вполне позитивно отражает возрастание "мягкой силы" и интенсификацию партнерских отношений. Согласно данным Федеральной службы государственной статистики, с января по декабрь 2015 г. количество туристов из Поднебесной составило 1122 тысячи, тогда как в 2018 г. количество приезжающих в Россию достигло уже 1690 тысяч человек. На период с января по июнь 2019 г. также имеются данные: 780 тысяч туристов [29]. Есть большая вероятность того, что по статистике к концу этого года количество туристов из Китая будет выше, чем в предыдущем году.

То же можно сказать и о выездном туризме из России в Китай. Количество русских туристов, посетивших Китай в 2015 г., составило 1284 тысячи человек, в 2018 г. количество посещений было почти в два раза больше - 2018 тысяч человек и, наконец, на период с января по июнь 2019 г. Китай посетило 1077 тысяч человек [29]. Таким образом, "мягкая сила" дает свои плоды в направлении туризма.

Стоит, однако, отметить, что несмотря на предпринятые меры, инвестируется туризм со стороны обеих стран не так активно. В этой области все еще не хватает высоко квалицированных кадров, качественного сервиса. И хотя государства обладают и ресурсами, и культурно-исторической базой, чего достаточно для завоевания интереса иностранных граждан, туризм все еще остается отраслью, где присутствуют нереализованные перспективы.

Помимо того, что оба государства стремятся добиться собственного успеха в каждой из сфер, их совместная работа также достойна внимания. Стоит отдельно выделить тот фракт, что страны с 2006 г. проводят "Перекрёстные годы", которые напрямую затрагивают "мягкую силу". В. В Путин и Си Цзиньпин пришли к соглашению о том, что количество студентов по обмену к 2020 г. должно достигнуть 100 тысяч человек, на той же встрече ректор СПбГУ Н. Кропачев отметил, что "партнерство двух стран в образовании и науке демонстрирует небывалую активность" [27]. В частности, он сообщил, что 5 июня было подписано соглашение о создании российского научно-исследовательского института в университете Цинхуа. Безусловен тот фракт, что такой взаимный обмен студентами также наращивает "мягкую силу", интенсифицирует связи Китая и России. 
Как упоминалось выше, "Перекрёстные годы" между странами начались в 2006 г., который стал годом России в Китае, а следующий, 2007 г., наоборот, - годом Китая в России. Далее следует аналогичный "взаимообмен" годами в сфере изучения языка, туризма: год русского/китайского языка в Китае/России, год российского/китайского туризма в Китае/России. Отдельно стоит отметить годы молодежных обменов с 2014 по 2015 г., годы обменов между СМИ России и Китая с 2016 по 2017 г.. В настоящий период времени, с 2018 г., между Россией и Китаем проходят годы межрегионального сотрудничества.

"Перекрёстные годы" играют положительную роль не только при развитии отношений государств, но и для их "мягкой силы". В годах прослеживается логичная закономерность: благодаря знанию языка народы смогли познакомиться с культурой ближе, благодаря туризму - непосредственно увидеть страну изнутри, молодежные обмены увеличили возможности для интенсификации отношений, настоящие года помогают сотрудничеству Китая и РФ стать крепче, а общественности - ближе.

Посылы "мягкой силы" являются важными элементами публичной дипломатии государства или того, как нация взаимодействует с общественностью за рубежом и общается с ней, продвигая национальные интересы на международных аренах. Калл, историк Анненбергского университета в Южной Калифорнии, разделил практику публичной дипломатии на следующие пять элементов [34, p. 33]:

1. Прослушивание. Сбор информации о международных мнениях, законными или тайными средствами шпионажа и сбора разведданных;

2. Адвокации. Продвижение конкретной политики, идей или интересов иностранной общественности, как правило, через собственные посольства в других странах;

3. Культурная дипломатия. Продвижение культурных ресурсов страны за рубежом и/или содействие культурной передаче за рубежом;

4. Биржевая дипломатия. Содействие взаимному обмену людьми с другими народами, например, в качестве студентов;

5. Международное вещание. Использование бюро новостей, радио- и телевизионного вещания и интернет-коммуникаций для взаимодействия с иностранной общественностью.

Если оставить в стороне слежку и сбор разведданных, можно выделить ряд областей, в которых Китай и Россия в последние годы проявляют активность по всем этим аспектам публичной дипломатии, в том числе следующие:

- проведение крупных международных мероприятий, таких как Олимпийские игры в Пекине в 2008 г. и Шанхайская всемирная выставка в 2010 г. в Китае, Олимпийские игры в Сочи 2014, саммит АТЭС в 2012 г. и ежегодный Восточный Экономический Форум в России;

- содействие международному обмену студентами и исследователями через образовательные инициативы;

- инвестирование в международную экспансию институтов Конфуция для преподавания китайского языка и культуры, программы по изучению русского языка на базах местных университетов в России;

- развитие услуг на иностранных языках в работе Центрального телевидения Китая (CCTV), China Radio International (CRI) и информационного агентства Синьхуа, а также в России - канал RT;

- продвижение механизмов совместного производства в развлекательных СМИ, таких как фильмы, телепрограммы и интернет-ресурсы.

Из недостатков реализации концепта "мягкой силы" необходимо отметить, что, несмотря на значительное количество потраченных ресурсов для укрепления позиций в мире и создания более открытого образа, действия российской власти во внутренней и внешней политике не всегда можно назвать "мягкими", а зачастую прямо противоположными идеям концепции "мягкой силы". Данная модель поведения исходит не только из действий на мировой арене, санкций, но и из отдельных высказываний некоторых политиков, видных деятелей культуры. Это все не способствует развитию того образа страны, который, вероятно, видит руководство. Помимо этого, хотя "мягкая сила" является американским детищем и предусматривает активную кооперацию с другими странами, в российском обществе преобладает тенденция закрытости. Не все россияне готовы принимать что-то "зарубежное", обычно они про- 
тивопоставляют себя иностранцам, отрицают западные ценности. Так Россия пытается противостоять доминирующей в мире системе либерально-демократических ценностей [13, с. 248]. В Китае, наоборот, Пекин открыто показывает свою заинтересованность и открытость Западу. В Китае идея политики "мягкой силы" развита лучше, она проводится скрупулёзно, взвешенно, пронизывает все области государственной жизни, руководство открыто к иностранным контактам и в целом направляет свои ресурсы на создание "позитивного" образа Китая. На международной арене Пекин предпочитает решать проблемы мирным путем, компромиссом и сглаживать конфоликты.

Феномен "мягкой силы", открытый в прошлом веке Дж. Наем, является сравнительно новым на мировой арене, но уже имеет огромный вес в политических кругах. "Мягкая сила" - это влияние одного человека или государства на других с целью добиться своих интересов ненасильственным методом, где особо выделяется и ценится культурная привлекательность страны. На примере Китая и России мы увидели, что "мягкая сила" является движущей для ряда таких областей, как туризм, спорт, образование, СМИ. Хотя политика "мягкой силы" и реализуется этими странами, они все же движутся по своему аутентичному пути развития, не забывая про исторические корни, а не апеллируя только к сиюминутным интересам.

Бесспорно, что каждая из областей нуждается в доработке и отдельном внимании со стороны государств. Но можно сделать вывод, что и Россия, и Китай развиваются по схожему пути и делают это в верном направлении. Особенно стоит отметить их успешное сотрудничество практически в каждой из областей, где они помогают друг другу наращивать опыт, становиться лучше, добиваться новых целей. "Перекрёстные годы" способствуют туристическому обмену, обмену знаниями, а также студентами и молодыми специалистами, которые в будущем смогут интенсифицировать отношения КНР и РФ, развивать "мягкую силу" и стать акторами на политической арене. Не зря образованию уделяется такое место, ведь, по сути, это служит развитию межгосударственных отношений в будущем. Помимо этого, при успешном прохождении обучения в стране-партнере, у студентов остаются положительные впечатления о принимающей стороне. Так формируется положительный образ Китая или России.

Что касается области СМИ, то она также требует своего переосмысления. К сожалению, у обеих стран сложился не самый позитивный образ в медиапространстве: КНР видится зарубежным странам как гегемон, слишком жёстко контролирующий новостные порталы, а Россия, можно сказать, застряла в прошлом и использует пропагандистский инструментарий для распространения тенденциозных позиций и мнений. Однако положительным здесь является то, что, несмотря на все перипетии, оба государства стараются развивать свою "мягкую силу", основали новостные каналы, транслирующие их точку зрения на мировые аудитории, перевели их на многочисленные языки, для того чтобы охватить как можно больше людей.

Туризм развивается активно, особенно между Россией и Китаем. Создаются все новые программы для удобства передвижения туристов (упрощение визового режима при въезде в Россию, "Перекрёстные года" и др.), с каждым годом прирост въездного и выездного туризма повышается, что еще раз доказывает эффрективность проводимой политики "мягкой силы" в отношении туризма.

Спорт теперь стал не только политичным, но и более того превратился в одно из направлений "мягкой силы", которое КНР и Россия сегодня активно развивают. Можно сделать вывод, что Китай справляется с поставленными задачами лучше, причем подобная нацеленность на развитие спорта началась еще в 80-е гг. с реформами Дэн Сяопина, даже до появления термина "мягкой силы". В Китае достаточно жёсткая система отбора спортсменов, антидопинговая пропаганда, строятся спортивные центры. Российское государство также инвестирует существенные средства в спортивную инфраструктуру через федеральные, региональные и местные целевые программы по развитию спорта, проводит крупные статусные международные соревнования. Проведение в 2014 г. Олимпийских игр в Сочи должно было стать триумфом России в области использования такого инструмента "мягкой силы" как спорт высоких достижений. В свое время именно Китай рассматривал свою Пекинскую 
олимпиаду как "супероружие" в сфере "мягкой силы", как гигантское событие, которое привлекло к Китаю внимание миллиардов людей. Последствия же Олимпиады в Сочи, в виде лишения Олимпийских медалей и отстранения российских спортсменов от Олимпийских игр, чемпионатов и кубков мира, мы пожинаем по сей день. Спорт оказался спорным и "подмоченным" инструментом продвижения образа нашей страны в мире.

"Перекрёстные года" в каждой из областей (в туризме и, в еще большей степени, образовании) сегодня показывают небывалую эфффективность. Вероятно, возросшее количество студенческих обменов между Россией и Китаем, а также наблюдаемый сегодня значительный приток туристов-результат именно перекрёстных годов. Это направление "мягкой силы", которое касается отношений обоих государств, стоит продолжать развивать и дополнять.

В общем и целом, деятельность обеих держав в направлении "мягкой силы", хотя и имеет свои отрицательные стороны и требует повышения әффективности, все же позитивно влияет на изменение их имиджа за рубежом и еще более активно способствует внутреннему развитию.

\section{Литература}

1. Актамов И. Г. Гуманитарная география трансграничья: ценностные доминанты и модели поведения иностранных студентов // Вестник Бурятского государственного университета. 2012. № 1-1. С. 5-10.

2. Актамов И. Г. "Мягкая сила" Китая: образовательные стратегии внешнеполитического влияния // Власть. 2019. № 3. С. 231-236.

3. Бояркина А. В. "Мягкая сила" как политический инструмент реализации внешней политики КНР на рубеже XX-XXI вв.: дисс. к. полит. н. Владивосток, 2015. $223 \mathrm{c.}$

4. Бурк В. Спорт в Китае: история развития и современное состояние // Наука в олимпийском спорте. 2014. № 1. С. 54-59.

5. Где и как учатся граждане КНР в России. 3.06.2019 // Министерство науки и высшего образования Российской Федерации [Электронный ресурc]. URL: https:// www.5top100.ru/news/104492/ (дата обращения: 20.12.2019).

6. Дмитрий Медведев принял участие в совещании по вопросам гуманитарного сотрудничества. 3.09.2012 // Правительство России [Электронный ресурс] URL: http:// government.ru/news/4467/ (дата обращения: 20.12.2019).

7. Доклад Ху Цзиньтао на 17-м съезде КПК. 24.10.2007 [Электронный ресурс] URL: http://russian.china.org.cn/china/archive/shiqida/2007-10/25/content_9120930.htm

8. Западные СМИ: Олимпиада поставила Украину "на паузу". 11.02.2014 [Электронный ресурc]. URL: http://www.odnako.org/blogs/zapadnie-smi-olimpiada-postavilaukrainu-na-pauzu/ (дата обращения: 20.12.2019).

9. Китай в 2018 году посетили 30,5 миллиона иностранных туристов. 19.02.2019 // РИА Новости [Электронный ресурс]. URL: https://ria.ru/20190219/1551066556.html (дата обращения: 20.12.2019).

10. Количество китайских туристов в России в 2017 году достигло 1,5 млн человек. 06.03.2018 // TACC [Электронный ресурc]. URL: https://tass.ru/obschestvo/5010584 (дата обращения: 20.12.2019).

11. Концепция внешней политики Российской Федеращии. Утверждена Президентом Российской Федерации В. В. Путиным. 12.02.2013 // Сайт МИД России. [Электронный pecypc]. URL: http://www.mid.ru/ru/foreign_policy/official_documents/-/asset_ publisher/CptICkB6BZ29/content/id/122186 (дата обращения: 20.12.2019).

12. Кухаренко С. В. Последние тенденции в политике "мягкой силы" России и Китая: сходства и различия // Россия и Китай в современных международных отношениях. М.: 2017. С. 679-684.

13. Кухаренко С. В. Проблемы публичной дипломатии России и пути их решения // Чтения памяти профрессора Евгения Петровича Сычевского. Сборник докладов. Благовещенск: Изд-во БГПУ, 2017. № 17. С. 244-249.

14. Люшен Г. Спорт и культура // Спорт, дух. ценности, культура. 1997. Вып. 2. C. $135-140$.

15. Михневич С. В. Панда на службе Дракона: основные направления и механизмы политики "мягкой силы" Китая // Вестник международных организаций. 2014. № 2. C. 95-129.

16. Муратшина К. Г. Программа сотрудничества регионов Дальнего Востока и Восточной Сибири РФ и северо-востока КНР на 2009-2018 гг. в российско-китайском трансграничном взаимодействии: значение, эволюция, риски // Вестник Томского государственного университета. 2017. № 417. С. 110-120. 
17. Мягкая сила. Российская газета - Федеральный выпуск. № 4783. [Электронный ресурc]. URL: https://rg.ru/2008/10/30/lavrov.html (дата обращения: 20.12.2019).

18. Наумов А. О. "Мягкая сила" и внешнеполитический имидж Российской Федерации / А. О. Наумов // Сетевое издание Центра исследований и аналитики Фонда исторической перспективы [Электронный ресурc]. URL: http://www.perspektivy.info/misl/ koncept/magkaja_sila_i_vneshnepoliticheskij_imidzh_rossijskoj_federacii_2015-03-30. htm (дата обращения: 20.12.2019).

19. Национальный проект "Образование". Минпросвещения России [Электронный ресурc]. URL: Режим доступа: https://edu.gov.ru/national-project/

20. Олимпийские рекорды. Самые дорогие Игры в истории. 13.02.2013 / Лига. net [Электронный ресурс]. URL: http://liga.net/infografica/98306_olimpiyskie-rekordysamye-dorogie-igry-v-istorii.htm (дата обращения: 20.12.2019).

21. Отчётный доклад генерального секретаря ЦК КПК Ху Цзиньтао на XVIII всекитайском съезде КПК. XVIII съезд Коммунистической партии Китая // Экспресс-информация ИДВ РАН. 2012. № 7. С. 14-106.

22. Песцов С. К. "Мягкая сила" в азиатско-тихоокеанском региональном контексте / С. К. Песцов, А. М. Бобыло, Л. Р. Рустамова, Л. Е. Козлов, М. С. Черепанов, А. А. Бояркина, К. Ф. Лыков, М. П. Першина // Теоретическая адаптация и национальные практики: монография. Владивосток: ДВФУ, 2016. 192 с.

23. Послание Президента России Федеральному Собранию Российской Федерации. 08.07.2000 // Президент России [Электронный pecypc]. URL: http://kremlin.ru/ events/president/transcripts/21480 (дата обращения: 20.12.2019).

24. Председатель КНР Си Цзиньпин нанес исторический визит в ЮНЕCKO. 27.03.2014 // Сайт E-NEWS [Электронный ресурc]. URL: http://e-news.com.ua/ show/333266.html (дата обращения: 20.12.2019).

25. Рабочая встреча с советником Президента Владимиром Толстым [Электронный pecypc]. URL: http://www.kremlin.ru/news/20855 (дата обращения: 20.12.2019).

26. Рособрнадзор впервые публикует рекомендации по подготовке к ЕГЭ по китайскому языку. 27.03.2019 // Федеральная служба по надзору в сфере образования и науки [Электронный ресурс]. URL: http://obrnadzor.gov.ru/ru/press_center/news/index. php?id_4=7052 (дата обращения: 20.12.2019).

27. Россия и Китай планируют нарастить число студентов по обмену. 06.06.2019 / РИА Новости [Электронный ресурc]. URL: https://ria.ru/20190606/1555346089.html (дата обращения: 20.12.2019).

28. Тарабако К. А. "Мягкая сила" культуры: эволюция концепции в трудах китайских ученых / Исторические, философские, политические и юридические науки, культурология и искусствоведение. Вопросы теории и практики. Тамбов: Грамота. 2016. № 7 (69): в 2-х ч. Ч. 2. С. 181-184.

29. Число въездных туристских поездок. Федеральная служба государственной статистики [Электронный ресурc]. URL: https://gks.ru/free_doc/new_site/business/torg/ tur/tab-tur1-1.htm (дата обращения: 20.12.2019).

30. Число выездных туристских поездок. Федеральная служба государственной статистики [Электронный ресурс]. URL: https://gks.ru/free_doc/new_site/business/torg/ tur/tab-tur1-2.htm (дата обращения: 20.12.2019).

31. Щедровицкий П. Г. Русский мир и транснациональное русское / Антология русской философии. М.: Изд-во "Сенсор", 2000. С. 374-388.

32. Beijing Defeats Almaty in Bid to Host 2022 Winter Olympics // The New York Times. 31.07.2015. [Электронный pecypc]. URL: http://www.nytimes.com/2015/08/01/ sports/olympics/beijing-selected-as-host-of-2022-winter-olympics.html?_r=0 (дата обращения: 20.12.2019).

33. Confucius Institute online. International Communication Digital Platform of Chinsese Language and Culture [Электронный pecypc]. URL: http://www.chinesecio.com

34. Cull, N.J. Public diplomacy before Gullion: The evolution of a phrase // Nancy Snow and Philip M. Taylor (eds), Routledge handbook of public diplomacy. New York and Oxon: Routledge. 2009. P. 32-35.

35. Is China attracting foreign visitors? // ChinaPower [Электронный ресурс]. URL: https://chinapower.csis.org/tourism/ (дата обращения: 20.12.2019).

36. Nye J. Soft Power: The Means to Success in World Politics. New York.: Public Affairs. 2004. 208 p.

37. Nye, J. America's Information Edge / J. Nye, W. Owen // Foreign Affairs. 1996. Vol. 75, № 2. P. 20-36.

38. Shambaugh, D. China's Soft Power Push: The Search for Respect / D. Shambaugh // Foreign Affairs. 2015. Vol. 94, № 4. P. 99-107.

39. The Soft Power 30. A Global Ranking of Soft Power 2016. Portland [Электронный pecypc]. URL: https://portland-communications.com/pdf/The-Soft-Power-30-Report-2016. pdf (дата обращения: 20.12.2019).

40. The Soft Power 30. A Global Ranking of Soft Power 2018. Portland [Электронный pecypc]. URL: https://softpower30.com/wp-content/uploads/2018/07/The-Soft-Power30-Report-2018.pdf (дата обращения: 20.12.2019). 
41. Ye P. Chinese Media 'Going Out' in Spanish Speaking Countries: The Case of CGTN-Español // Westminster Papers in Communication and Culture. 2018. Vol. 13. № 1. P. 81-97.

42. 王沪宁. 作为国家实力的文化: 软权力//复旦学报 (社会科学版) [Ван Хунин. Культура как национальная сила: мягкая сила. Шанхай, 1993. С. 91-97.]

43. 阎学通. 中国软实力有待提高 (Янь Сюэтун. Мягкая сила Китая увеличивает свое влияние) [Электронный ресурc]. URL: http://www.aisixiang.com/data/13332.html (дата обращения: 20.12.2019).

44. 蒋晓丽、李建华. 文化软实力与传媒软实力 (Цзян Сяоли, Ли Цзяньхуа. Мягкая сила культуры и воздействие СМИ) [Электронный pecypc]. URL: http://media. people.com.cn/GB/137684/9616858.html (дата обращения: 20.12.2019).

\section{Транслитерация по ГОСТ 7.79-2000 система Б}

1. Aktamov I. G. Gumanitarnaya geografiya transgranich'ya: tsennostnye dominanty i modeli povedeniya inostrannykh studentov // Vestnik Buryatskogo gosudarstvennogo universiteta. 2012. № 1-1. S. 5-10.

2. Aktamov I. G. "Myagkaya sila" Kitaya: obrazovatel'nye strategii vneshnepoliticheskogo vliyaniya // Vlast'. 2019. № 3. S. 231-236.

3. Boyarkina A. V. "Myagkaya sila" kak politicheskij instrument realizatsii vneshnej politiki KNR na rubezhe XX-XXI vv.: diss. k. polit. n. Vladivostok, 2015. $223 \mathrm{~s}$.

4. Burk V. Sport v Kitae: istoriya razvitiya i sovremennoe sostoyanie // Nauka v olimpijskom sporte. 2014. № 1. S. 54-59.

5. Gde i kak uchatsya grazhdane KNR v Rossii. 3.06.2019 // Ministerstvo nauki i vysshego obrazovaniya Rossijskoj Federatsii [Ehlektronnyj resurs]. URL: https://www.5top100.ru/news/104492/ (data obrashheniya: 20.12.2019).

6. Dmitrij Medvedev prinyal uchastie $\mathrm{v}$ soveshhanii po voprosam gumanitarnogo sotrudnichestva. 3.09.2012 // Pravitel'stvo Rossii [Ehlektronnyj resurs] URL: http://government.ru/news/4467/ (data obrashheniya: 20.12.2019).

7. Doklad Khu Tszin'tao na 17-m s"ezde KPK. 24.10.2007 [Ehlektronnyj resurs] URL: http://russian.china.org.cn/china/archive/shiqida/2007-10/25/content_9120930.htm

8. Zapadnye SMI: Olimpiada postavila Ukrainu "na pauzu". 11.02.2014 [Ehlektronnyj resurs]. URL: http://www.odnako.org/blogs/zapadnie-smi-olimpiada-postavila-ukrainu-na-pauzu/ (data obrashheniya: 20.12.2019).

9. Kitaj v 2018 godu posetili 30,5 milliona inostrannykh turistov. 19.02.2019 // RIA Novosti [Ehlektronnyj resurs]. URL: https://ria.ru/20190219/1551066556.html (data obrashheniya: 20.12.2019).

10. Kolichestvo kitajskikh turistov v Rossii v 2017 godu dostiglo $1,5 \mathrm{mln}$ chelovek. 06.03.2018 // TASS [Ehlektronnyj resurs]. URL: https://tass.ru/obschestvo/5010584 (data obrashheniya: 20.12.2019).

11. Kontseptsiya vneshnej politiki Rossijskoj Federatsii. Utverzhdena Prezidentom Rossijskoj Federatsii V. V. Putinym. 12.02.2013 // Sajt MID Rossii. [Ehlektronnyj resurs]. URL: http://www.mid.ru/ru/foreign_policy/official_documents/-/asset_publisher/CptICkB6BZ29/content/id/122186 (data obrashheniya: 20.12.2019).

12. Kukharenko S. V. Poslednie tendentsii v politike "myagkoj sily" Rossii i Kitaya: skhodstva i razlichiya // Rossiya i Kitaj v sovremennykh mezhdunarodnykh otnosheniyakh. M.: 2017. S. 679-684.

13. Kukharenko S. V. Problemy publichnoj diplomatii Rossii i puti ikh resheniya // Chteniya pamyati professora Evgeniya Petrovicha Sychevskogo. Sbornik dokladov. Blagoveshhensk: Izd-vo BGPU, 2017. № 17. S. 244-249.

14. Lyushen G. Sport i kul'tura // Sport, dukh. tsennosti, kul'tura. 1997. Vyp. 2. S. $135-140$.

15. Mikhnevich S. V. Panda na sluzhbe Drakona: osnovnye napravleniya i mekhanizmy politiki "myagkoj sily" Kitaya // Vestnik mezhdunarodnykh organizatsij. 2014. № 2. S. 95-129.

16. Muratshina K. G. Programma sotrudnichestva regionov Dal'nego Vostoka i Vostochnoj Sibiri RF i severo-vostoka KNR na 2009-2018 gg. v rossijsko-kitajskom transgranichnom vzaimodejstvii: znachenie, ehvolyutsiya, riski // Vestnik Tomskogo gosudarstvennogo universiteta. 2017. № 417. S. 110-120.

17. Myagkaya sila. Rossijskaya gazeta - Federal'nyj vypusk. № 4783. [Ehlektronnyj resurs]. URL: https://rg.ru/2008/10/30/lavrov.html (data obrashheniya: 20.12.2019).

18. Naumov A. O. "Myagkaya sila" i vneshnepoliticheskij imidzh Rossijskoj Federatsii / A. O. Naumov // Setevoe izdanie TSentra issledovanij i analitiki Fonda istoricheskoj perspektivy [Ehlektronnyj resurs]. URL: http://www.perspektivy.info/misl/koncept/ magkaja_sila_i_vneshnepoliticheskij_imidzh_rossijskoj_federacii_2015-03-30.htm (data obrashheniya: $\overline{2} 0.12 .2019$ ). 
19. Natsional'nyj proekt "Obrazovanie". Minprosveshheniya Rossii [Ehlektronnyj resurs]. URL: Rezhim dostupa: https://edu.gov.ru/national-project/

20. Olimpijskie rekordy. Samye dorogie Igry v istorii. 13.02.2013 / Liga.net [Ehlektronnyj resurs]. URL: http://liga.net/infografica/98306_olimpiyskie-rekordy- samye-dorogie-igry-v-istorii.htm (data obrashheniya: 20.12.2019).

21. Otchyotnyj doklad general'nogo sekretarya TSK KPK KHu TSzin'tao na XVIII vsekitajskom s"ezde KPK. XVIII s"ezd Kommunisticheskoj partii Kitaya // EHkspress-informatsiya IDV RAN. 2012. № 7. S. 14-106.

22. Pestsov S. K. "Myagkaya sila" v aziatsko-tikhookeanskom regional'nom kontekste / S. K. Pestsov, A. M. Bobylo, L. R. Rustamova, L. E. Kozlov, M. S. CHerepanov, A. A. Boyarkina, K. F. Lykov, M. P. Pershina // Teoreticheskaya adaptatsiya i natsional'nye praktiki: monografiya. Vladivostok: DVFU, 2016. $192 \mathrm{~s}$.

23. Poslanie Prezidenta Rossii Federal'nomu Sobraniyu Rossiǐskoí Federatsii. 08.07.2000 // Prezident Rossii [Ehlektronnyj resurs]. URL: http://kremlin.ru/events/president/transcripts/21480 (data obrashheniya: 20.12.2019).

24. Predsedatel' KNR Si TSzin'pin nanes istoricheskii vizit v YUNESKO. 27.03.2014 // Sajt E-NEWS [Ehlektronnyj resurs]. URL: http://e-news.com.ua/show/333266.html (data obrashheniya: 20.12.2019).

25. Rabochaya vstrecha s sovetnikom Prezidenta Vladimirom Tolstym [Ehlektronnyj resurs]. URL: http://www.kremlin.ru/news/20855 (data obrashheniya: 20.12.2019).

26. Rosobrnadzor vpervye publikuet rekomendatsii po podgotovke $\mathrm{k}$ EGEH po kitajskomu yazyku. 27.03.2019 // Federal'naya sluzhba po nadzoru v sfere obrazovaniya i nauki [Ehlektronnyj resurs]. URL: http://obrnadzor.gov.ru/ru/press_center/news/index. php?id_4=7052 (data obrashheniya: 20.12.2019).

27. Rossiya i Kitaj planiruyut narastit' chislo studentov po obmenu. 06.06.2019/ RIA Novosti [Ehlektronnyj resurs]. URL: https://ria.ru/20190606/1555346089.html (data obrashheniya: 20.12.2019).

28. Tarabako K. A. "Myagkaya sila" kul'tury: ehvolyutsiya kontseptsii v trudakh kitajskikh uchenykh / Istoricheskie, filosofskie, politicheskie i yuridicheskie nauki, kul'turologiya i iskusstvovedenie. Voprosy teorii i praktiki. Tambov: Gramota. 2016. № 7 (69): v 2-kh ch. CH. 2. S. 181-184.

29. CHislo v"ezdnykh turistskikh poezdok. Federal'naya sluzhba gosudarstvennoj statistiki [Ehlektronnyj resurs]. URL: https://gks.ru/free_doc/new_site/business/torg/tur/ tab-tur1-1.htm (data obrashheniya: 20.12.2019).

30. CHislo vyezdnykh turistskikh poezdok. Federal'naya sluzhba gosudarstvennoj statistiki [Ehlektronnyj resurs]. URL: https://gks.ru/free_doc/new_site/business/torg/tur/ tab-tur1-2.htm (data obrashheniya: 20.12.2019).

31. SHHedrovitskij P. G. Russkij mir i transnatsional'noe russkoe / Antologiya russkoj filosofii. M.: Izd-vo "Sensor", 2000. S. 374-388.

32. Beijing Defeats Almaty in Bid to Host 2022 Winter Olympics // The New York Times. 31.07.2015 [Ehlektronnyj resurs]. URL: http://www.nytimes.com/2015/08/01/ sports/olympics/beijing-selected-as-host-of-2022-winter-olympics.html?_r=0 (data obrashheniya: 20.12.2019).

33. Confucius Institute online. International Communication Digital Platform of Chinsese Language and Culture [Ehlektronnyj resurs]. URL: http://www.chinesecio.com

34. Cull, N.J. Public diplomacy before Gullion: The evolution of a phrase // Nancy Snow and Philip M. Taylor (eds), Routledge handbook of public diplomacy. New York and Oxon: Routledge. 2009. P. 32-35.

35. Is China attracting foreign visitors? // ChinaPower [Ehlektronnyj resurs]. URL: https://chinapower.csis.org/tourism/ (data obrashheniya: 20.12.2019).

36. Nye J. Soft Power: The Means to Success in World Politics. New York.: Public Affairs. 2004. $208 \mathrm{p}$.

37. Nye, J. America's Information Edge / J. Nye, W. Owen // Foreign Affairs. 1996. Vol. 75, № 2. P. 20-36.

38. Shambaugh, D. China's Soft Power Push: The Search for Respect / D. Shambaugh // Foreign Affairs. 2015. Vol. 94, № 4. P. 99-107.

39. The Soft Power 30. A Global Ranking of Soft Power 2016. Portland [Ehlektronnyj resurs]. URL: https://portland-communications.com/pdf/The-Soft-Power-30-Report-2016. pdf (data obrashheniya: 20.12.2019).

40. The Soft Power 30. A Global Ranking of Soft Power 2018. Portland [Ehlektronnyj resurs]. URL: https://softpower30.com/wp-content/uploads/2018/07/The-Soft-Power-30-Report-2018.pdf (data obrashheniya: 20.12.2019).

41. Ye P. Chinese Media 'Going Out' in Spanish Speaking Countries: The Case of CGTN-Español // Westminster Papers in Communication and Culture. 2018. Vol. 13. № 1. P. 81-97.

42. 王沪宁. 作为国家实力的文化: 软权力//复旦学报 (社会科学版) [Van KHunin. Kul'tura kak natsional'naya sila: myagkaya sila. SHankhaj, 1993. S. 91-97.] 
43. 阎学通. 中国软实力有待提高 (YAn' Syuehtun. Myagkaya sila Kitaya uvelichivaet svoe vliyanie) [Ehlektronnyj resurs]. URL: http://www.aisixiang.com/data/13332.html (data obrashheniya: 20.12.2019).

44. 蒋晓丽、李建华. 文化软实力与传媒软实力 (TSzyan Syaoli, Li TSzyan'khua. Myagkaya sila kul'tury i vozdejstvie SMI) [Ehlektronnyj resurs]. URL: http://media.people.com.cn/GB/137684/9616858.html (data obrashheniya: 20.12.2019).

Владимирова Д. А., Журбей Е. В., Карловская А. А. "Мягкая сила" во внешней политике России и Китая: особенности национальных стратегий.

Созданная Дж. Наем концепция "мягкой силы" в XXI веке получила широкое распространение в Китае и России, став одним из ключевых компонентов ведения внутренней и международной политики. В статье представлен обзор таких областей, как образование, СМИ, туризм и спорт, которые формируют политику "мягкой силы" КНР и РФ. Дан анализ перекрестных лет между государствами. Выявлена специфика достижения поставленных задач и основные инструменты для реализации политики "мягкой силы" как на международной арене, так и внутри стран. Также в статье проведен сравнительный анализ успешности реализации "мягкой силы" в Китае и России.

Ключевые слова: "лягкая сила", Китай, Россия, СМИ, образование, туризм, спорт, Институтьь Конфуция, Олилпийские игрьь

Vladimirova D. A., Zhurbey E. V., Karlovskaya A. A. "Soft power" in foreign policies of Russia and China: features of national strategies.

The concept of "soft power" created by J. Nye, in the 21st century became widespread in China and Russia and nowadays is one of the key components of domestic and international politics. This article provides an overview of such spheres as education, mass-media, tourism and sports, which form the "soft power" of China and Russia. The analysis of cross years between countries is given. The specifics of achieving objectives and the main tools for the implementation of policies "soft power" both in the international arena and within countries are revealed. The article also provides a comparative analysis of the success of implementing "soft power" in China and Russia.

Key words: soft power, China, Russia, mass-media, education, tourism, sport, Confucius Institutes, Olympic Games

Для цитирования: Владимирова Д. А., Журбей Е. В., Карловская А. А. "Мягкая сила" во внешней политике России и Китая: особенности национальных стратегий // Ойкумена. Регионоведческие исследования. 2020. № 1. C. 123-137. DOI: 10.24866/1998-6785/2020-1/123-137

For citation: Vladimirova D. A., Żhurbey E. V., Karlovskaya A. A. "Soft power" in foreign policies of Russia and China: features of national strategies // Ojkumena. Regional researches. 2020. № 1. P. 123-137. DOI: 10.24866/1998-6785/2020-1/123-137 


\section{Современный военный потенциал КНДР: неядерный аспект}

\section{Введение}

Сегодня не вызывает сомнений оказание существенного влияния военно-политических усилий КНДР на комплекс региональной безопасности Северо-Восточной Азии (CBA), а также глобальную стабильность. В этой связи необходимо дать оценку возможностей Корейской Народной Армии (КНА) по ведению военных действий в современных условиях, а также возникновения вооружённого конфликта на Корейском полуострове. Актуальность исследования обусловлена обострением кризиса в СВА в связи с интенсификацией КНДР ракетно-ядерной программы и следующим за этим усилением военных возможностей США и их союзников в регионе, что создаёт угрозу для интересов РФ и КНР. Вместе с тем, ядерный потенциал Пхеньяна является не единственным фактором, удерживающим Вашингтон и его союзников от военного решения кризиса. Руководство Северной Кореи уделяет значительное внимание совершенствованию боевых средств Корейской Народной Армии и тактики их применения, в том числе, для сохранения решающего превосходства при осуществлении национальной обороны в условиях "полной и проверяемой" денуклеаризации, на которой настаивает нынешняя американская администрация.

С учётом важного места, которое занимает так называемая "корейская проблема" в современных международных отношениях (прим авт. - речь идёт о комплексном явлении, связанном скорее с нерешённостью характера отношений КНДР с РК и США, нежели только о ракетно-ядерном аспекте), требует ответа вопрос о способности КНА в своём нынешнем состоянии обеспечить надёжную оборону территории страны, в том числе в условиях использования вероятным противником современных военных технологий. Данный аспект важен ещё и в контексте оценки возможности какой-либо стороны нанести военное поражение КНДР и произвести насильственную смену режима Ким Чен Ына, например, в случае, если Пхеньян откажется от обладания ядерным оружием, тем более что такая практика уже применялась Западом.

Значимость исследования определяется также тем, что действия Пхеньяна представляют собой пример реализации интересов безопасности и развития в условиях почти полной международной изоляции и ограниченности ресурсов. Исследовательский интерес вызывает и то, что поведение Пхеньяна хотя и соответствует логике политического реализма, однако привносит ряд новых и уникальных моментов. Кроме того, требуется его дальнейшее изучение в динамике для более точного определения последствий как для самой КНДР, так и для комплекса региональной безопасности.

Анализируя имеющийся исследовательский задел, нельзя не обратить внимания на существенное несовпадение точек зрения авторов, специализирующихся на проблемах Корейского полуострова, и специалистов исключительно по военно-техническим аспектам. Также значительное количество отчётных и аналитических материалов зарубежных структур, как представляется, выполнено сообразно конкретным политическим ожиданиям заказчиков и может быть учтено только в описательной и количественной частях, без внимания к содержащимся там оценкам и предложениям. В условиях отсутствия объективной и достоверной открытой информации о количественном составе

$$
\text { (C) Губин А. В., } 2020
$$

ГУБИН Андрей Владимирович, канд. полит. наук, доцент кафедры международных отношений Дальневосточного федерального университета (г. Владивосток), эксперт Российского института стратегических исследований (е. Москва). E-mail: gubin.av@dvfu.ru

Работа выполнена при финансовой поддержке Фонда целевого капитала ДВФУ. 
КНА и тем более её качественном состоянии затруднено применение традиционных методов исследования, в том числе компаративного. В этой связи, в ряде случаев автор вынужден прибегать к достаточно вольным, со строго научной точки зрения, эвристическим и интуитивным приёмам и суждениям.

\section{Проблема оценки боеспособности Корейской Народной Армии}

Одной из наиболее спорных тем в экспертной среде является боевой потенциал Корейской Народной Армии (КНА). В литературе достаточно часто встречаются сведения о её численности в 1,2 млн человек, нескольких тысячах единиц бронетехники и десятке тысяч единиц ствольной и реактивной артиллерии, что делает её четвёртой в мире. [12; 24]. Вместе с тем, действительная боеспособность КНА не связана напрямую с количественными параметрами, даже если они приблизительно соответствуют указанным в источниках. Скептики полагают, что "пробелы" в информации относительно военного потенциала страны ничем не могут быть заполнены - никакого секретного оружия у КНДР нет. Кроме этого, официальной информации Пхеньяна доверять нельзя, так как северокорейское руководство неоднократно злоупотребляло мистификациями, пропагандистскими заявлениями и блефом [10; 20]. Алармисты, оценивая возможности КНА, исходят из результатов испытаний Пхеньяном различных боевых систем, однако склонны преувеличивать успехи страны. В ряде случаев излишне оптимистические оценки успехов северокорейских военных оказывают воздействие на мировое общественное мнение, которое, порой, разделяют и политические лидеры, впадая в итоге в панические настроения. Однако стоит отметить, что и недооценка возможностей КНДР в деле национальной обороны крайне опасна, поскольку может создать иллюзию возможности "блицкрига" против неё. Взвешенным и оправданным с точки зрения методологии и анализа исторического опыта КНДР представляётся всё же критический подход, который, как уже отмечалось, исследователям приходится применять в условиях чрезвычайной полярности мнений по данному вопросу и отсутствия полных и достоверных данных.

Современный политический курс Пхеньяна представляет собой опору на экономические реформы и ядерное сдерживание в качестве основы развития государства и обеспечения стабильности правящего режима. Развитие ракетно-ядерного потенциала имеет и экономический резон - расходы на его совершенствование существенно меныше затрат на производство и содержание значительного количества обычных вооружений. Фактически, ядерное оружие для Пхеньяна - наиболее эффективный и экономный способ обеспечения национальной безопасности, позволяющий перераспределить фринансирование в пользу повышения уровня жизни граждан и развития производства потребительской продукции [9]. При этом КНДР, по крайней мере, декларативно, отказалась от нацеливания своего ядерного оружия на Республику Корея, отметив, что собирается использовать его только как крайнее средство для сдерживания американской агрессии, а не "против наших братьев" [23]. Однако в Пхеньяне, вероятно, осознают, что даже обладание ядерным оружием не является панацеей от возможной внешней агрессии, потому неядерный потенциал КНА также крайне важен для обороноспособности страны, например, в условиях отказа от обладания ЯО, его вывода из строя вероятным противником или же осознанного решения неиспользования ядерного потенциала в военном конфрликте.

Политика КНДР в сфрере национальной обороны является одним из главных фракторов, дестабилизирующих региональный комплекс безопасности Северо-Восточной Азии. При этом более определяющую роль играет не военный потенциал КНДР, а скорее его спекулятивное использование Вашингтоном для оправдания своих действий по увеличению военного присутствия возможностей в АТР, которые инициируют реакцию соседних государств (в том числе, Китая и России) и повышают напряжённость на глобальном уровне.

\section{Организация и численный состав вооружённых сил}

Серьёзным аргументом в пользу более реалистического толкования военных возможностей Северной Кореи является небольшой военный бюджет 
страны. По ряду оценок, он составляет около 20 \% от ВВП страны или 6-8 млрд долл. США Для сравнения, оборонные расходы Сеула и Токио превышают 34 и 46 млрд дол., соответственно [25, с. 11-31; 26, с. 9].

В настоящее время численность личного состава Корейской Народной Армии, составляет, вероятно, не более 850 тыс. человек, встречаются оценки и в 650 тыс. военнослужащих в боевых подразделениях. Не менее 4 млн человек состоят в резерве, а общие мобилизационные ресурсы - 6,2 млн человек. $К$ военизированным формированиям можно отнести Рабоче-крестьянскую Красную гвардию (резервисты старшего возраста) - около 1,5 млн чел., Молодёжную красную гвардию - 700 тыс. чел. (старшеклассники), войска Министерств общественной безопасности и государственной безопасности - 30 тыс. чел. В КНДР действует обязательная воинская повинность с 18 лет, срок службы колеблется от 3 до 8 лет в зависимости от вида и рода войск, привлекаются и женщины. Не менее 200 тысяч относятся к вспомогательным подразделениям, включая строительные и охранные, подчинённые Инженерному Бюро ЦК ТПК и Министерству общественной безопасности [14; 15, с. 12-22].

Некоторые эксперты отмечают, что северокорейские военнослужащие уступают телосложением американским и южнокорейским солдатам, однако важной чертой бойцов КНА являются высокие моральные качества личного состава, выносливость и владение навыками рукопашного боя. Страна обладает и серьезными запасами легкого и стрелкового оружия - более 30 млн единиц, что позволяет в случае необходимости вооружить и всё гражданское население $[14 ; 21]$. Вместе с тем, проверить боевой дух и готовность к самопожертвованию в мирных условиях эмпирически довольно сложно, примеры личного героизма военнослужащих из истории Корейской войны 1950-1953 гг. вряд ли являются достаточным доказательством.

Руководство вооружёнными силами с 2016 г. осуществляет Государственный Совет КНДР, председателем которого является маршал Ким Чен Ын. Согласно положениям Конституции, к функциям данного органа относится решение вопросов обороноспособности государства, осуществление контроля над исполнением поручений, постановлений и распоряжений или их отмена. Госсовет уполномочен вводить военное положение и объявлять мобилизацию. Руководство вооружёнными силами, решение задач оперативного управления и боевой готовности осуществляет Генеральный штаб как консультативный орган при Министерстве народных вооружённых сил.

Ориентация нового военно-политического руководства КНДР на экономические редрормы несколько снизила хозяйственную нагрузку на армию. Она реже используется как дешёвая рабочая сила, однако всё ещё играет огромную роль в народном хозяйстве - автомобильные и железные дороги, мосты, линии связи в основном возводятся строительными подразделениями. По свидетельству очевидцев, качество работ довольно высокое, что говорит о дисциплине и квалификации военнослужащих [8, с. 340-349]. Вполне вероятно, что по мере поступления на вооружение новых типов военной техники, и прежде всего, ракет, регулярная численность вооружённых сил может быть уменьшена еще на 200 тыс. человек, что позволит увеличить финансирование НИОКР в области национальной обороны, а также высвободит значительное количество рабочей силы.

\section{Сухопутные войска}

Основу КНА традиционно составляют сухопутные войска (CB). Общая численность - до 700 тыс. человек. В структуру управления входят 4 командования (артиллерии, зенитной артиллерии, обороны столицы и бронетанковых войск) и примерно 15 корпусов: 8 пехотных, 1 танковый, 4 механизированных, 1 корпус специального назначения, 1 артиллерийский. Представляется вероятным, что опора на корпуса и дивизии как основные боевые единицы постепенно будет меняться на более гибкую - бригадную, которая уже введена в артиллерийских и ракетных частях, однако такие части корпусного подчинения, как артиллерия особой мощности, вертолётные эскадрильи, спецназ сокращены не будут.

Основа военной стратегии страны - активная оборона. Дислокация частей и подразделений КНА основана на принципах построения эшелонированной обороны. Первый эшелон размещается вблизи демилитаризованной 
зоны (ДМЗ) и должен предотвратить продвижение войск противника вглубь КНДР, задачи прорыва южнокорейских приграничных укреплений в настоящий момент открыто не провозглашаются. Второй эшелон развернут на расстоянии суток перехода от границы, а также по побережью, главная его задача - ликвидация прорывов противника. Главная цель третьего эшелона - оборона Пхеньяна. Четвертый эшелон расположен на границах с КНР и РФ, в мирное время он относится к "учебно-резервным частям", а в случае боевых действий представляет собой своеобразные "силы последней надежды".

Стоит учитывать, что протяжённость ДМЗ всего 241 км и многочисленная северокорейская армия способна создать сплошную линию обороны, а в случае прорыва приграничных укреплений отступить на ещё более выгодные позиции. Малые размеры страны позволяют быстро производить переброску войск и сократить сроки мобилизации.

Количество боевой техники в вооруженных силах КНДР, приводимое в справочниках, является достаточно условной величиной в условиях недостатка запасных частей и топлива. КНА обладает около 5,5 тыс. единицами бронетехники (танков и бронемашин), 7 тыс. стволами артиллерии, включая реактивную, и 7 тыс. минометами [4, с. 8-14]. В составе СВ имеются 8 дивизионов тактических ракет (ТP) KN-02 (32 пусковых установок со 100-150 ракетами, дальность стрельбы до 100 км) и 6 дивизионов ТР "Луна-М" (24 ПУ, ок. 100 ракет, дальность стрельбы 70 км) [15, с. 10-20]. Значительная часть военной техники и вооружений $\mathrm{CB}$ представлена устаревшими образцами советского и китайского образцов, доля современных вооружений национальной разработки невелика. В войска также поступают основные боевые танки и бронемашины, представляющие собой творческую переработку Т-72 и БТР-80, соответственно, в том числе с использованием опыта восточноевропейских конструкторов. Имеются и свои версии легкого и стрелкового оружия, противотанковых комплексов и артсистем. Однако это не даёт армии ощутимых преимуществ в случае конфликта, гораздо более важной представляется возможная тактика использования.

Серьезное подспорье для КНА - сложный ландшафт (преимущественно гористая местность, густая тайга, уязвимые перевалы и переправы), недостаточно развитая дорожная сеть, наличие сложных метеоусловий в зависимости от сезона, а также большое число городов с плотной застройкой. Вероятно, с учётом этого фракта, северокорейская пехота подготовлена к использованию местности и многочисленных искусственных укреплений, а также обороне с использованием подземных коммуникаций. В ряде случаев будет возможно использовать танковые группы для ударов, отсекающих части возможного противника друг от друга и снабжения. Наступательные операции против армии КНДР на территории страны практически невозможны - потенциальному захватчику придётся передвигаться через заранее созданные дефиле, велика опасность засад и ловушек, затруднена навигация.

Существенный боевой потенциал имеется у северокорейского спецназа, численность которого составляет до 80 тыс. бойцов. При необходимости возможно проникновение бойцов диверсионных подразделений на территорию Южной Кореи через тоннели под ДМЗ, с лёгких самолетов, малых подлодок, а также под видом перебежчиков и иностранных туристов [21].

Военные эксперты традиционно высоко оценивают огневые возможности северокорейской артиллерии. Действительно, расчёты орудий и реактивных систем залпового огня (РС30) способны эффрективно действовать против боевых соединений и тыловых объектов противника, а также наносить контрценностные удары по невоенным целям [2]. Главные позиции, включая направления наступления и возможные места высадки, скорее всего, уже пристреляны корейскими артиллеристами. По некоторым оценкам, контроль высот и засадная тактика полностью нивелирует превосходство западной техники, так как бой придётся вести на ближних дистанциях и в условиях ограниченной видимости. Многочисленная северокорейская артиллерия фрактически держит в заложниках 23,5 миллиона жителей сеульской агломерации, пригороды которой начинаются в 26 км от 38-ой параллели [7]. Примечательно, что развёрнутые сегодня оборонительные системы, включая американские THAAD (Terminal High Altitude Air Defense) и корейские KAMD (Korean Air and Missile Defense), бессильны против артиллерийских обстрелов [5]. Однако 
реальная боевая ценность при стрельбе на расстояния более 50 км имеется лишь у некоторых северокорейских систем, общим количеством пока не более 500 единиц. Все они не могут быть единовременно скрытно развёрнуты вблизи ДМЗ и вести огонь долгое время. Учитывая этот факт, в последнее время КНА активно испытывает различные варианты дальнобойных реактивных систем залпового огня, способных поражать цели на удалении до 300 км, что позволит им вести огонь с защищённых позиций в глубине территории страны.

Ряд российских экспертов отмечает, что в сухопутных войсках остро стоит проблема снабжения топливом и продовольствием, ремонта и модернизации военной техники и оборудования. В случае начала активных военных действий запасов топлива и продовольствия хватит не более чем на два месяца [1].

\section{Военно-воздушные силы и противовоздушная оборона}

Важным элементом вооруженных сил КНДР является противовоздушная оборона, которая включает в себя зенитные части сухопутных войск, зенитные части BBC и зенитные части резерва. На вооружении стоит более 10 тыс. стволов зенитной артиллерии, которые способны как вести заградительный огонь, так и уверенно поражать самолёты и беспилотные летательные аппараты (БПЛА). На вооружении КНА имеется до 15 тыс. переносных зенитных комплексов (ПЗРК). Мобильные зенитные ракетные комплексы (ЗРК) в основном устаревшие, однако имеется некоторое количество систем KN-06, близких по характеристикам к российским C-300, которые прикрывают Пхеньян и пусковые районы баллистических ракет. Определённым потенциалом обладают системы "Бук" советского образца. На вооружении сохраняется 20 полков стационарных зенитных комплексов C-75M, C-125M-1 и C-200B, однако они обладают низкими помехозащищенностью и мобильностью. В целом, система противовоздушная оборона страны достаточно плотная и устойчивая к потерям - один только Пхеньян прикрывает более 3 тысяч различных систем, однако, с учётом номенклатуры имеющихся систем, наибольшая её поражающая способность может быть достигнута на сравнительно небольшой дальности (до 30 км). Данных о современных комплексах обнаружения и наведения в системе ПВО КНДР не имеется, что, в случае реального отсутствия такого оборудования, существенно обесценивает возможности по борьбе с малозаметными целями, действиям в условиях постановки помех, а также отражению массированных атак ракетными средствами поражения, выпущенными за пределами зоны эфффективного противодействия.

Стоит отметить, что КНДР пытается модернизировать существующие средства ПВО и создавать новые. В частности, в войска, предположительно, уже поступил комплекс "Пхёнгаэ-5" ("Молния-5"), схожий по характеристикам с российской системой С-300ПМ. Адаптированный китайский вариант данной технологии, вероятно, мог быть получен через Иран. На парадах последних лет показаны и новые зенитно-ракетные установки для Сухопутных войск [16].

Военно-воздушные силы формально многочисленны, однако достоверных данных о боеготовых единицах не имеется. Определенную ценность имеют около 20 тактических истребителей Миг-29Б, около 30 штурмовиков Су-25, а также порядка 48 более "пожилых" истребителей Миг-23. Армейская авиация обладает 24 ударными вертолетами Ми-24, ок. 30 многоцелевыми Ми-8, а также 150 легкими MD-500 и Ми-2.

Главные слабые места северокорейских военно-воздушных сил - недостаток запасных частей и керосина. Существенный вклад в снижение боеготовности авиации внесли и санкции Совета безопасности ООН. Отмечались попытки нелегального вывоза из России запасных частей для авиационной техники, которые пресекались российскими таможенными органами. Сложности у КНДР возникают с оснащением истребителей современными ракетами "воздух-воздух". Российские эксперты не исключают, что ВВС располагают 10-12 ядерными боеприпасами в виде свободнопадающих авиабомб, которые гипотетически могут быть применены самолётами тактической авиации [5].

На первоначальном этапе боевых действий авиация способна в ограниченном объеме выполнять как задачи перехвата, так и поддержки назем- 
ных войск. Однако, по оценкам военных экспертов, мобилизация КНА 2010 г. продемонстрировала плохую подготовку ВВС - лётные навыки и техническое состояние самолетов тогда оказались недостаточными для участия в боевых операциях любого рода, кроме самоубийственных атак и отвлечения сил противника на ложные цели $[11 ; 22]$. За прошедшее время, как представляется, техническое состояние авиационной техники только ухудшилось, так как в условиях санкций запасные части и оборудование достать проблематично, как и наладить самостоятельный выпуск сложных систем и агрегатов (двигатели, авионика и т.д.).

Целесообразно отметить, что несовершенство системы ПВО страны отчасти компенсируется размещением ключевых объектов военной промышленности и управления вооружёнными силами в глубине территории страны, в том числе в подземных объектах высокой степени защищённости.

\section{Военно-морские силы}

ВМС КНА представлены в основном "москитным фрлотом" (малые боевые корабли и катера) и частями береговой обороны. Три фррегата с управляемым ракетным оружием (УРО) и артиллерийские корветы использовать достаточно сложно из-за невысокого боевого потенщиала - на них нет систем ПВО и современного электронного оборудования. Новых корветов "Нампо" в составе всего два и вряд ли возможно их использовать открыто из-за высокого риска потери. Построить современные крупные надводные корабли или же приобрести их за рубежом Пхеньян в нынешних условиях не может. Определённую опасность для вероятного противника представляют скоростные ракетные катера, которые могут действовать из засад. Многочисленные десантно-высадочные средства, в том числе на воздушной подушке, предназначены для захвата островов и прибрежных районов $\mathrm{PК} \mathrm{в} \mathrm{случае} \mathrm{начала} \mathrm{кон-}$ фрликта. При этом, для доставки катеров специального назначения могут быть использованы и рыболовецкие траулеры [21]. Противодесантная оборона и поражение кораблей противника на дальности до 100 км обеспечивается ракетными и артиллерийскими комплексами. В ВМФ КНА есть и значительное количество морских мин, которые, вероятно, сформированы в заграждения в Японском и Жёлтом морях. Однако стоит учитывать, что обмен кораблями и взаимодействие между Западным и Восточным фрлотами затруднены даже в мирное время.

Дискуссионным вопросом является наличие у КНДР морских носителей ядерного оружия. В строю ВМС имеется одна дизель-электрическая лодка типа "Синпхо" или "Горэ" ("Кит"), которая способна нести в ограждении рубки и корпусе одну баллистическую ракету (БРПЛ) "Пуккынсон-2". Лодка, по всей видимости, не несёт боевого дежурства с ракетным вооружением на борту. Строительство серии подобных кораблей, о чём неоднократно сообщали иностранные эксперты, не слишком рационально - лодки малы и не обладают необходимыми мореходностью, автономностью и скрытностью. Тем не менее, не исключено, что заложено до пяти корпусов типа "Усовершенствованный Горэ", каждый под три перспективные ракеты "Пуккынсон-3" с дальностью свыше 2 тыс. км. [18; 19]. Говорить о скором и вообще возможном вступлении лодок этого типа в строй довольно затруднительно, однако корейские военные не прекращают работ по совершенствованию БРПЛ, а в октябре 2019 г. осуществили её запуск с "подводного объекта".

Создание в КНДР подводной лодки, способной нести значительное количество ракет (8-16 единиц) в прочном корпусе по типу советского проекта 667 или китайской "Ся" - технологически неразрешимая для военной промышленности страны задача в нынешних условиях. Судостроительные предприятия страны не в состоянии построить такой корабль самостоятельно, а взять готовый корпус и силовую установку северокорейским специалистам просто негде.

Проекты по скрытному размещению пусковых установок баллистических ракет на переоборудованных торговых судах, вероятно, остаются нереализованными, особенно с учётом повышенного международного контроля над любыми судами под северокорейским флагом. Существуют предположения о возможном размещении БРПЛ на погружённых платформах в пределах территориальных вод КНДР, однако реальных подтверждений такой деятельно- 
сти, кроме того, что с таких объектов проводились испытательные запуски, не существует.

Достаточно распространено мнение, что КНДР может использовать многочисленные дизельные подводные лодки проекта 033 для атаки на коммуникации вероятного противника. Однако данные корабли построены на элементной базе 1950-х гг., тихоходны и ненадёжны. Некоторую ценность имеют малые субмарины типа "Санг-О", которые могут торпедировать корабли противника в прибрежных водах, минировать, и доставлять диверсантов.

Значение авиации и фрлота в Корейской народной армии постоянно падает, так как обеспечить паритет в авиационной и морской мощи с потенциальным противником невозможно. ВВС и ВМС скорее представляют собой вспомогательные силы для поддержки наземных войск.

\section{Возможности ракетного оружия КНДР}

Самый молодой вид ВС КНДР - Стратегические ракетные войска, в которых служит около 13 тыс. человек. По оценкам Института стратегических исследований [25, с. 11-31], в составе находится до пяти дивизионов баллистических ракет средней дальности (БРСД) "Нодон" (10 пусковых установок с 90 ракетами, дальность стрельбы до 1300 км), полк оперативно-тактических ракет (ОТР) "Хвасон-6" (более 30 ПУ с 200 ракетами, дальность стрельбы 300-550 км).

Активно испытываются новые твёрдотопливные ракеты типа "Пуккынсон-1" в виде грунтового комплекса на гусеничном шасси или баллистической ракеты подводных лодок - "Пуккынсон-2" [28], усовершенствованные варианты "Скадов" (SCUD-ER, 800 км), а также ракеты малой дальности неустановленного образца, окрещённые рядом экспертов "кимскандерами" (ок. 500 Км).

Специалисты уверенно говорят о готовности командования КНА к боевому применению ракет с дальностью от 70 до 1300 км, которые имеются на вооружении в значительном количестве. Технологии производства и применения такого рода оружия хорошо отработаны, тогда как изделия с большей дальностью, тем более на мобильных платформах, - слишком сложны технологически и вряд ли могут выпускаться массово северокорейской военной промышленностью [27].

Подавляющее большинство образцов ракетного оружия КНДР рассчитаны на применение ядерной боевой части. Однако в условиях неопределённого прогресса в части миниатюаризации боеголовок и очевидного нежелания Пхеньяна использовать ядерное оружие первым [17], ракеты могут быть оснащены обычными (фугасными или кассетными) боевыми частями и применяться для ответных ударов по важным военно-промышленным и стратегическим центрам, включая американские объекты в Республике Корея и Японии. Об этом свидетельствует и сместившийся в последнее время акцент в испытаниях КНДР своего ракетного оружия - основу составляют реактивные снаряды систем залпового огня повышенного могущества, тактические и оперативно-тактические ракеты.

Несмотря на значительную численность КНА, сложно оценить её реальную боеспособность только по данным, приводимым в международных справочниках и официальных заявлениях ЦТАК. Основу техники СВ, ВВС и ВМС составляют устаревшие образцы, новые системы поступают на вооружение в ограниченном количестве и вряд ли могут оказать решающее воздействие в случае конфрликта. Гораздо более важной составляющей военного планирования КНДР и её конкретной деятельности по обеспечению национальной обороны представляет тактика использования имеющихся сил и средств. Корейская народная армия в своём нынешнем состоянии построена по чисто оборонительной кондигурации и способна осуществлять эшелонированную оборону, удерживать стратегически важные пункты и при необходимости наносить контрудары ракетным оружием и артиллерией даже без использования ядерных боевых частей. Проводимые рядом специалистов аналогии с кампаниями США и коалиции в Ираке в 1991 и 2003 гг. вряд ли могут быть 
применены к КНДР в силу коренных различий в характере театров военных действий, а также внутриполитической ситуации в данных странах. Как уже отмечалось, территория Северной Кореи представляет собой преимущественно гористую местность с множеством рек и населенных пунктов с плотной застройкой; вызывает сомнение и способность Вашингтона предварительно подкупить или устранить властные и военные элиты страны.

Количественное и качественное превосходство сил США и их союзников в Восточной Азии вкупе с явной линией Вашингтона на изоляцию КНДР не оставило Пхеньяну иного выбора, кроме как создать эффрективные средства сдерживания в виде баллистических ракет с ядерной боевой частью, способные поразить военные и гражданские цели не только в регионе, но и на континентальной территории США. Несмотря на отсутствие подтверждённой информации о наличии у КНДР развёрнутых ядерных боезарядов на стратегических носителях, проведённых испытаний, сопровождающихся воинственной риторикой ЦТАК, пока оказывается достаточно для обеспечения военной безопасности страны. Второй гарантией безопасности от проведения против Северной Кореи военной операции является способность вооружённых сил достаточно долго удерживать оборону рубежей и защищать наиболее важные объекты в случае коноликта с применением конвенциального оружия. Стоит также учитывать, что значительная часть корейской военной промышленности, склады и командные пункты размещены в укреплениях в глубине страны, что затрудняет даже их выявление, не говоря уже о гарантированном дистанционном поражении. Не стоит сбрасывать со счетов и наличие у Пекина обязательств по оказанию военной помощи Пхеньяну в случае агрессии третьей стороны.

Вместе с тем, администрация Д. Трампа явно заинтересована в провоцировании кризисной ситуации на Корейском полуострове для отвлечения внимания американской общественности от более насущных проблем, а также приобретения дополнительных политических очков [3]. Напряжённость в Северо-Восточной Азии выгодна также американским производителями вооружений и военной техники, которые получают новые контракты от Министерства обороны США и оказывают давление на союзников Вашингтона для закупки ими дорогостоящих систем [13].

Как полагают в МИД России, "авантюры Пхеньяна не должны давать повода для наращивания военной активности в регионе и тем более реализации силовых планов, поскольку конфронтационная логика чревата катастрофическими последствиями как для Корейского полуострова, так и для региона в целом" [6]. Таким образом, Москва фрактически недвусмысленно даёт понять, что состояние военной промышленности и вооружённых сил КНДР само по себе не оказывает решающего воздействия на комплекс региональной безопасности Восточной Азии. Наибольшим же дестабилизирующим потенциалом обладает именно использование Вашингтоном и его союзниками северокорейского фактора для оправдания наращивания собственных военных возможностей в регионе, направленных, прежде всего, против Китая и России. 


\section{Литература}

1. Асмолов К. Военный потенциал КНДР - реализм и франтазии // Новое восточное обозрение. 24.08.2015. [Электронный pecypc]. URL: http://ru.journal-neo. org/2015/08/24/voenny-j-potentsial-kndr-realizm-i-fantazii/ (дата обращения: 22.01.2019).

2. Военный конфликт США и КНДР начнётся с ракетных ударов // Взгляд. 18.04.2017. [Электронный ресурс]. URL: https://www.vz.ru/world/2017/4/18/866789.html (дата обращения: 05.07.2019).

3. Выступление и ответы на вопросы СМИ Министра иностранных дел России С.В. Лаврова в ходе пресс-конференщии по итогам 24-го заседания СМИД ОБСЕ, Вена, 8 декабря 2017 года // Сайт МИД РФ. [Электронный ресурc]. URL: http://www. mid.ru/ru/press_service/minister_speeches/-/asset_publisher/ 7OvQR5KJWVmR/content/ id/2983345 (дата обрашения: 07.03.2019).

4. Горынов А., Юрьев П. Корейская народная армия вооружённых сил КНДР // Зарубежное военное обозрение. 2017. №2. С. 8-14.

5. Евсеев В. Перспективы создания в Республике Корея противоракетной обороны // Корейский полуостров в эпоху перемен / Ред. А. Жебин. М.: ИДВ РАН, 2016.

6. Заявление заместителя Постоянного представителя Российской Федерации при ООН В.К. Сафронкова по мотивам голосования при принятии резолющии Совета Безопасности ООН по КНДР. 2 июня 2017 года. [Электронный ресурс]. URL: http:// russiaun.ru/ru/news/sc_sak (дата обращения: 22.01.2019).

7. Ивашенцов Г. Угрозы Р. Тиллерсона и корейский цугцванг // Российский совет по международным делам. 21.03.2017. [Электронный ресурс]. URL: http:// russiancouncil.ru/analytics-and-comments/analytics/ugrozy-r-tillersona-i-koreyskiytsugtsvang/ (дата обращения: 11.08.2019).

8. Кирьянов О. Северная Корея. М.: Рипол классик, 2017. 432 с.

9. Коростиков М., Сафронов И. КНДР ужала ядерный заряд до угрожающих размеров // Коммерсант. 05.09.2017, [Электронный ресурc]. URL: https://www.kommersant. ru/doc/3402378 (дата обращения: 01.06.2019).

10. Лихолетов А. Мистификации по обе стороны Тихого океана // Независимое военное обозрение. 2013. 39(780).

11. Ржавеющие BВC Северной Кореи // Военное обозрение. 25.08.2011. URL: https:// topwar.ru/7884-rzhaveyuschie-vvs-severnoy-korei.html (дата обращения: 15.05.2019).

12. Сокирко В. Ярость чучхе: чем КНДР собирается воевать с США // Звезда. 18.04.2017. [Электронный ресурс]. URL: https://tvzvezda.ru/news/vstrane_i_mire/ content/201704180738-gfxv.htm (дата обращения: 01.11.2019).

13. Строкань С. "Огонь и ярость" Дональда Трампа // Коммерсант. 09.08.2017. [Электронный ресурc]. URL: https://www.kommersant.ru/doc/3379556 (дата обращения: 22.01.2019).

14. Цыганок А. На что способна армия КНДР? [Электронный ресурc]. URL: http:// www.tsiganok.ru/publications/esmi/doc/494 (дата обращения: 11.03.2019).

15. Чуприн К. Военная машина КНДР: Корейская народная армия вчера и сегодня. Краткий информационно-аналитический справочник. М.: Викта. 2016. 548 с.

16. Чуприн К. Пхеньян сверкнул "Молнией" // Военное обозрение. 2017. 3 июня. [Электронный ресурc]. URL: https://topwar.ru/117117-phenyan-sverknul-molniey.html (дата обращения: 11.10.2019).

17. Broad, William J. North Korea Will Have the Skills to Make a Nuclear Warhead by 2020, Experts Say // The New York Times. 2016. Sep. 9. [Электронный ресурc]. URL: http://www.nytimes.com/2016/09/10/science/north-korea-nuclear-weapons.html?ref=world (дата обращения: 26.01.2019).

18. Cook Damen. North Korea's Most Important Submarine Base // The Diplomat. 2017. March 27. [Электронный pecypc]. URL: http://thediplomat.com/2017/03/northkoreas-most-important-submarine-base/ (дата обращения: 22.05.2019).

19. Hecker, Siegfried. North Korea's Nuclear Program - What, How, When and Why. Paper presented at the "Can President Trump Make a Deal with North Korea?" Workshop. CENESS. Moscow. 2017. April 27.

20. Is Russia Sightless or Is It Mimicking Blind: Researcher of Institute for International Studies // KCNA. August 9, 2017. [Электронный pecypc]. URL: http:// www.kcna.kp/kcna.user.article.retrieveNewsViewInfoList.kcmsf\#this (дата обращения: 11.04.2019).

21. New North Korean threat: hovercrafts and navy sniper brigades // Asian Times. 2018. Febr. 17. [Электронный ресурc]. URL: http://www.atimes.com/article/new-n-koreathreat-hovercraft-navy-sniper-brigades/ (дата обращения: 02.07.2019).

22. North Korean Air Force left to rot // Strategy Page. 2011. Oct. 19. [Электронный pecypc]. URL: https://www.strategypage.com/htmw/htproc/articles/20111019.aspx (дата обращения: 22.01.2019).

23. North Korea tells South it will not discuss nuclear arms in future talks // Reuters. 2018. January 9. [Электронный ресурc]. URL: https://www.trtworld.com/asia/north- 
korea-tells-south-it-will-not-discuss-nuclear-arms-in-future-talks-14070 (дата обращения: 30.04.2019).

24. Taylor Adam. North Korea claims to have almost 5 million have signed up to join its already enormous army // The Washington Post. 2017. September 28. [Электронный pecypc]. URL: https://www.washingtonpost.com/news/worldviews/wp/2017/09/28/northkorea-claims-almost-5-million-have-signed-up-to-join-its-already-enormous-army/ (дата обращения: 15.11.2019).

25. The Conventional Military Balance on Korean Peninsula 2018. London: The International Institute for Strategic Studies, 2018. 76 р. [Электронный ресурc]. URL: https://www.iiss.org/-/media/images/comment/military-balance-blog/2018/june/theconventional-military-balance-on-the-korean-peninsula.pdf?la=en\&hash= 5982B6EB2C1 1218FE9A989C720E824EE95788A15 (дата обращения: 22.01.2019).

26. Tian Nan, Fleurant Aude, Wezeman Peter D., Wezeman Siemon T. Trends in world military expenditure, 2016. Factsheet. SIPRI, 2017. [Электронный pecypc]. URL: https://www.sipri.org/sites/default/files/Trends-world-military-expenditure-2016.pdf (дата обращения: 12.04.2019).

27. Warrick Joby. The secret to Kim's success? Some experts see Russian echoes in North Korea's missile advances // The Washington Post. 2017. July 8. [Электронный ресурc]. URL: https://www.washingtonpost.com/world/national-security/the-secret-to-kims-successsome-experts-see-russian-echoes-in-north-koreas-missiles-advances/2017/07/08/5d4f5fca6364-11e7-a4f7-af34fc1d9d39_story.html?utm_term=.17041e273d2f (дата обращения: 22.01.2019).

28. 김정은동지께서 지상대지상중장거리전략탄도탄 《북극성-2》 형시험발 사를 현지에서 지도 [Товарищ Ким Чен Ын присутствовал на испытаниях ракеты средней дальности "Пуккынсон-2"] // ЦTAК. 13.02.2017. [Электронный ресурс]. URL: http://kcna.kp/kcna.user.article.retrieveNewsViewInfoList.kcmsf;jsessionid=60334C672D 4E10D4E0A20C37065A93DA\#this (дата обращения: 05.03.2019).

\section{Транслитерация по ГОСТ 7.79-2000 система Б}

1. Asmolov K. Voennyj potentsial KNDR - realizm i fantazii // Novoe vostochnoe obozrenie. 24.08.2015. [Ehlektronnyj resurs]. URL: http://ru.journal-neo.org/2015/08/24/ voenny-j-potentsial-kndr-realizm-i-fantazii/ (data obrashheniya: 22.01.2019).

2. Voennyj konflikt SSHA i KNDR nachnyotsya s raketnykh udarov // Vzglyad. 18.04.2017. [Ehlektronnyj resurs]. URL: https://www.vz.ru/world/2017/4/18/866789.html (data obrashheniya: 05.07.2019).

3. Vystuplenie i otvety na voprosy SMI Ministra inostrannykh del Rossii S.V. Lavrova $v$ khode press-konferentsii po itogam 24-go zasedaniya SMID OBSE, Vena, 8 dekabrya 2017 goda // Sajt MID RF. [Ehlektronnyj resurs]. URL: http://www.mid.ru/ru/press service/minister_speeches/-/asset_publisher/ 7OvQR5KJWVmR/content/id/2983345 (data obrashheniya: 07.03.2019).

4. Gorynov A., YUr'ev P. Korejskaya narodnaya armiya vooruzhyonnykh sil KNDR // Zarubezhnoe voennoe obozrenie. 2017. №2. S. 8-14.

5. Evseev V. Perspektivy sozdaniya v Respublike Koreya protivoraketnoj oborony // Korejskij poluostrov v ehpokhu peremen / Red. A. ZHebin. M.: IDV RAN, 2016.

6. Zayavlenie zamestitelya Postoyannogo predstavitelya Rossijskoj Federatsii pri OON V.K. Safronkova po motivam golosovaniya pri prinyatii rezolyutsii Soveta Bezopasnosti OON po KNDR. 2 iyunya 2017 goda. [Ehlektronnyj resurs]. URL: http://russiaun.ru/ $\mathrm{ru} /$ news/sc_sak (data obrashheniya: 22.01.2019).

7. Ivashentsov G. Ugrozy R. Tillersona i korejskij tsugtsvang // Rossijskij sovet po mezhdunarodnym delam. 21.03.2017. [Ehlektronnyj resurs]. URL: http://russiancouncil. $\mathrm{ru} /$ analytics-and-comments/analytics/ugrozy-r-tillersona-i-koreyskiy-tsugtsvang/ (data obrashheniya: 11.08.2019).

8. Kir'yanov O. Severnaya Koreya. M.: Ripol klassik, 2017. 432 s.

9. Korostikov M., Safronov I. KNDR uzhala yadernyj zaryad do ugrozhayushhikh razmerov // Kommersant. 05.09.2017, [Ehlektronnyj resurs]. URL: https://www.kommersant.ru/doc/3402378 (data obrashheniya: 01.06.2019).

10. Likholetov A. Mistifikatsii po obe storony Tikhogo okeana // Nezavisimoe voennoe obozrenie. 2013. 39(780).

11. Rzhaveyushhie VVS Severnoj Korei // Voennoe obozrenie. 25.08.2011. URL: https:// topwar.ru/7884-rzhaveyuschie-vvs-severnoy-korei.html (data obrashheniya: 15.05.2019).

12. Sokirko V. YArost' chuchkhe: chem KNDR sobiraetsya voevat' s SSHA // Zvezda. 18.04.2017. [Ehlektronnyj resurs]. URL: https://tvzvezda.ru/news/vstrane_i_mire/content/201704180738-gfxv.htm (data obrashheniya: 01.11.2019).

13. Strokan' S. "Ogon' i yarost"' Donal'da Trampa // Kommersant. 09.08.2017. [Ehlektronnyj resurs]. URL: https://www.kommersant.ru/doc/3379556 (data obrashheniya: 22.01.2019). 
14. TSyganok A. Na chto sposobna armiya KNDR? [Ehlektronnyj resurs]. URL: http:// www.tsiganok.ru/publications/esmi/doc/494 (data obrashheniya: 11.03.2019).

15. Chuprin K. Voennaya mashina KNDR: Korejskaya narodnaya armiya vchera i segodnya. Kratkij informatsionno-analiticheskij spravochnik. M.: Vikta. 2016. 548 s.

16. Chuprin K. Pkhen'yan sverknul "Molniej" // Voennoe obozrenie. 2017. 3 iyunya. [Ehlektronnyj resurs]. URL: https://topwar.ru/117117-phenyan-sverknul-molniey.html (data obrashheniya: 11.10.2019).

17. Broad, William J. North Korea Will Have the Skills to Make a Nuclear Warhead by 2020, Experts Say // The New York Times. 2016. Sep. 9. [Ehlektronnyj resurs]. URL: http://www.nytimes.com/2016/09/10/science/north-korea-nuclear-weapons.html?ref=world (data obrashheniya: 26.01.2019).

18. Cook Damen. North Korea's Most Important Submarine Base // The Diplomat. 2017. March 27. [Ehlektronnyj resurs]. URL: http://thediplomat.com/2017/03/north-koreas-most-important-submarine-base/ (data obrashheniya: 22.05.2019).

19. Hecker, Siegfried. North Korea's Nuclear Program - What, How, When and Why. Paper presented at the "Can President Trump Make a Deal with North Korea?" Workshop. CENESS. Moscow. 2017. April 27.

20. Is Russia Sightless or Is It Mimicking Blind: Researcher of Institute for International Studies // KCNA. August 9, 2017. [Ehlektronnyj resurs]. URL: http://www.kcna.kp/ kcna.user.article.retrieveNewsViewInfoList.kcmsf\#this (data obrashheniya: 11.04.2019).

21. New North Korean threat: hovercrafts and navy sniper brigades // Asian Times. 2018. Febr. 17. [Ehlektronnyj resurs]. URL: http://www.atimes.com/article/new-n-koreathreat-hovercraft-navy-sniper-brigades/ (data obrashheniya: 02.07.2019).

22. North Korean Air Force left to rot // Strategy Page. 2011. Oct. 19. [Ehlektronnyj resurs]. URL: https://www.strategypage.com/htmw/htproc/articles/20111019.aspx (data obrashheniya: 22.01.2019).

23. North Korea tells South it will not discuss nuclear arms in future talks // Reuters. 2018. January 9. [Ehlektronnyj resurs]. URL: https://www.trtworld.com/asia/north-koreatells-south-it-will-not-discuss-nuclear-arms-in-future-talks-14070 (data obrashheniya: 30.04.2019).

24. Taylor Adam. North Korea claims to have almost 5 million have signed up to join its already enormous army // The Washington Post. 2017. September 28. [Ehlektronnyj resurs]. URL: https://www.washingtonpost.com/news/worldviews/wp/2017/09/28/northkorea-claims-almost-5-million-have-signed-up-to-join-its-already-enormous-army/ (data obrashheniya: 15.11.2019).

25. The Conventional Military Balance on Korean Peninsula 2018. London: The International Institute for Strategic Studies, 2018. 76 p. [Ehlektronnyj resurs]. URL: https:// www.iiss.org///media/images/comment/military-balance-blog/2018/june/the-conventional-military-balance-on-the-korean-peninsula.pdf?la=en\&hash= 5982B6EB2C11218FE9A989C720E824EE95788A15 (data obrashheniya: 22.01.2019).

26. Tian Nan, Fleurant Aude, Wezeman Peter D. Wezeman Siemon T. Trends in world military expenditure, 2016. Factsheet. SIPRI, 2017. [Ehlektronnyj resurs]. URL: https://www.sipri.org/sites/default/files/Trends-world-military-expenditure-2016.pdf (data obrashheniya: 12.04.2019).

27. Warrick Joby. The secret to Kim's success? Some experts see Russian echoes in North Korea's missile advances // The Washington Post. 2017. July 8. [Ehlektronnyj resurs]. URL: https://www.washingtonpost.com/world/national-security/the-secret-to-kims-success-some-experts-see-russian-echoes-in-north-koreas-missiles-advances/2017/07/08/5d4f5fca-6364-11e7-a4f7-af34fc1d9d39_story.html?utm_term=.17041e273d2f (data obrashheniya: 22.01.2019).

28. 김정은동지께서 지상대지상중장거리전략탄도탄 《북극성-2》 형시험 발사를 현지에서 지도 [Tovarish Kim CHen Yn prisutstvoval na ispytaniyakh rakety srednej dal'nosti "Pukkynson-2"] // TSTAK. 13.02.2017. [Ehlektronnyj resurs]. URL: http:// $\mathrm{kcna} . \mathrm{kp} / \mathrm{kcna}$.user.article.retrieveNewsViewInfoList. kcmsf;jsessionid=60334C672D4E10D4E0A20C37065A93DA\#this (data obrashheniya: 05.03.2019). 


\section{аспект. \\ Губин А. В. Современный военный потенциал КНДР: неядерный}

Статья посвящена исследованию возможностей Корейской Народной Армии в своём нынешнем состоянии противостоять возможным вызовам и угрозам в военной сфоре. Несмотря на то, что главный акцент в политике сдерживания США и их союзников от агрессивных действий северокорейское руководство делает на ядерное оружие и средства его доставки, обычным вооружениям также уделяется важная роль при организации обороны страны. Военный потенциал КНДР, несмотря на международную изоляцию в условиях санкций Совета Безопасности ООН и односторонних ограничений со стороны ряда стран, не уменьшается. Более того, северокорейская промышленность в состоянии разрабатывать, испытывать и развёртывать новые образцы вооружений и военной техники. Вооружённые силы страны переформатированы сообразно новой концепции активной обороны с упором на оборонительные действий на собственной территории с попутным нанесением ударов по вероятному противнику имеющимися средствами поражения, включая ядерные боеприпасы. В результате, военное и технологическое превосходство над КНДР со стороны США и их союзников оказывается недостаточным аргументом для возможного силового решения северокорейской ракетно-ядерной проблемы как в "точечном" варианте или через проведение масштабной интервенции. Вместе с тем, Вашингтон, вероятно, намерен использовать сложившуюся патовую ситуацию в свою пользу, наращивая собственные военные возможности в Северо-Восточной Азии и сплачивая своих союзников - Республику Корея и Японию - вокруг активно продвигаемой идеи необходимости формирования силового противовеса КНДР.

Ключевые слова: КНДР, военный потенииал, Корейский кризис, региональная безопасность

Gubin A. V. Contemporary DPRK's military capacity: conventional arms.

The article is mostly focused on research of the contemporary Korean People's Army capacity in terms of its capability to confront effectively emerged challenges an threats. Despite of the fact that Pyongyang outlined core accent on the obtained nuclear weapon and means of delivery in deterrence strategy applied to the USA and its allies, conventional arms are still extremely valuable in national defense planning. The DPRK's military power hasn't being diminished even under the UNSC and unilateral sanctions imposed. Moreover North Korean military industry is still able to develop, produce, test and deploy some arms and munitions. Korean People's Army was dramatically redesigned due to the new vision of the active defense with the stronger incline to the national territory's defense simultaneously hitting the adversary with all means including nuclear devices. Apparently, military and technological superiority the USA and its allies have over Pyongyang isn't a decisive argument for the forceful solution of the North Korean missile and nuclear problem both in high-precision strikes of mass intervention options. However Washington is seemed to utilize such a stalemate and turn it in the respective favor justifying military rebalancing and build-up as well as binding and keeping in check Japan and South Korea around the obsessed idea of DPRK's threat.

Key words: DPRK, military capacity, Korean crisis, regional security

Для цитирования: Губин А. В. Современный военный потенциал КНДР: неядерный аспект // Ойкумена. Регионоведческие исследования. 2020. № 1. C. 138-149. DOI: 10.24866/19986785/2020-1/138-149

For citation: Gubin A. V. Contemporary DPRK's military capacity: conventional arms // Ojkumena. Regional researches. 2020. № 1. P. 138-149. DOI: 10.24866/1998-6785/2020-1/138149 


\section{Возникновение и становление Народно-Трудового Союза российских солидаристов}

Организация, известная с 1958 г. по настоящее время как Народно-Трудовой Союз российских солидаристов (НТC), официально была создана на объединительном съезде в Белграде. Съезд прошёл с 1 по 5 июля 1930 г., поэтому 1 июля принято считать датой основания НТС. Однако истоки движения российских солидаристов восходят ещё к 1924 г., когда на руднике Перник в Болгарии возник первый кружок русской молодёжи. Именно довоенный период (1924-1941 гг.) является самым не изученным в деятельности организации.

Рамки данной статьи не позволяют подробно остановиться на истории проблемы, тем не менее отметим, что существует уже целый ряд исследований об НТС и русской эмиграции, от научных статей и монографий до кандидатских и докторских диссертаций, среди которых три монографии и кандидатская диссертация принадлежат автору данной статьи $[1 ; 2 ; 3 ; 4]$.

До 1990 г. существовало два основных подхода к изучению НТС: советский и антисоветский. Представители первого стремились доказать, что НTC - это предатели родины, пособники фашистов и наймиты западных спецслужб. Наиболее типичными примерами являются монографии Н. Н. Яковлева и Л. К. Шкаренкова $[20,18]$. Антисоветский подход представляли в основном эмигранты (в большинстве своём действующие или бывшие члены HTC), западные учёные и пропагандисты, а также их отечественные последователи, которые пытались представить российских солидаристов героями борьбы с тоталитарным режимом. Квинтэссенцией второго подхода можно считать брошюру "НТС: Мысль и дело", вышедшую под редакцией тогдашнего председателя НТС Б. С. Пушкарёва [11].

Среди более поздних работ можно выделить коллективный труд "Эмиграция и репатриация в России" (2001) [19], в котором всесторонне рассматривается феномен русской эмиграции, а также среди прочих эмигрантских объединений некоторое внимание уделено НТС и вошедшим в него группам. Кроме того, следует выделить кандидатскую диссертацию Ю. С. Цурганова "Российская военная эмиграция в Европе 1939-1945 гг." (2001), кандидатскую диссертацию Л. В. Климович "Идеология и деятельность молодёжных организаций русского зарубежья в 1920-е - начале 1940-х гг. (на материалах Союза младороссов и Национального союза нового поколения) (2010), монографию профрессора Г. И. Каневской об истории русской диаспоры в Австралии, докторскую диссертацию ещё одного члена НТС К. В. Александрова "Генералитет и офицерские кадры вооружённых формирований Комитета освобождения народов России 1943-1946 гг." (2016), сборник "В поисках истины" под общей редакцией А. В. Попова, а также сборник "От зарубежья до Москвы. Народно-Трудовой Союз (НТC) в воспоминаниях и документах" (2014), вышедший под редакцией тогдашнего председателя исполнительного бюро НТС В. А. Сендерова $[7 ; 9 ; 10 ; 13 ; 17]$. Следует отметить, что НТС - организация затухающая, в последнее время он сосредоточился в основном на издательской и культурно-просветительской деятельности, поэтому свежих исследований об этом политическом движении не столь много.

В качестве методологической базы исследования были использованы традиционные общеметодологические принципы: объективность, историзм, всесторонность, альтернативность. При написании статьи применялись хронологический, логико-аналитический, сравнительно-исторический и системный методы исследования, а также метод анализа документов.

АЛЕКСЕЕВ Даниил Юрьевич, канд. полит. наук, доцент кафедры политологии Дальневосточного федерального университета (2. Владивосток). E-mail: daniilalekseev@mail.ru 
Цель данной статьи - проанализировать деятельность НТС в довоенный период 1924-1941 гг. Из неё вытекают основные исследовательские задачи:

1. выявить предпосылки возникновения движения российских солидаристов;

2. выделить основные этапы деятельности НТС в довоенный период;

3. проанализировать основные цели организации, методы их достижения и практические результаты.

Для создания любого политического движения есть свои предпосылки. В результате Гражданской войны в эмиграции оказалось 1,2 миллиона россиян, настроенных против советской власти, ещё 0,8 миллиона стали русскими меньшинствами в новых государствах на окраинах бывшей Российской империи [14, с. 9]. Таким образом, существовало около 2 миллионов выходцев из России, маргинальных по своему положению в зарубежье и настроенных против большевиков. Они пытались осмыслить произошедшее в их стране, а многие готовы были продолжать борьбу против красных.

Молодёжь в силу юношеского максимализма часто была настроена более радикально, по сравнению с поколением "отцов", острее ощущала и переживала собственную ненужность и недоступность обычных путей самореализации, открытых для сверстников в других странах. "Тяжёлая, непривычная для большинства работа, тоска по Родине, постепенная утрата веры в скорое возвращение в Россию" - всё это способствовало консолидации молодых россиян $[8$, с. 51$]$.

К тому же молодые выходцы из России считали "отцов" виновным в том, что они допустили революцию и, не сумев объединиться для борьбы против большевиков, проиграли Гражданскую войну. Те, кто покинул родину почти детьми, чувствовали себя потерянным поколением. "Нацмальчиков", как их прозвали "отцы", не устраивала и пассивность "стариков".

Старшее поколение видело два пути конца коммунизма. Левые круги, от меньшевиков до П. Н. Милюкова, надеялись на эволюцию советского режима. Правые, в первую очередь, военные, рассчитывали на изменение международной обстановки, которое сделает возможным "весенний поход". То и другое подразумевало ожидание. В ожидании лучших времён многие пытались сохранить духовное наследие старой России, веру, язык и передать детям любовь к ней. Но "нацмальчики" видели в этом продолжение "постыдного безволия" и "духовного кризиса", которые позволили большевикам прийти к власти $[11$, с. 10].

В середине 1920-х гг. в местах компактного расселения русской эмигрантской диаспоры стали возникать группы молодёжи, кружки, "ордена", участники которых были недовольны деятельностью "отцов". Одним из первых объединений стал Кружок русской национальной молодёжи, появившийся в 1924 г. на болгарском руднике Перник. Поначалу это объединение в основном устраивало вечеринки, гуляния, спектакли. Почти одновременно в том же 1924 г. в Королевстве сербов, хорватов и словенцев независимо от Болгарии приступила к активной деятельности родственная группа - Союз русской национальной молодёжи (CPHМ). Первоначально он сотрудничал с Высшим Монархическим Советом, а затем переориентировался на Русский общевоинский союз (РОВС), созданный генералом П. Н. Врангелем и стоявший на национальных, но непредрешенческих позициях.

Переломным событием, заставившим молодёжь размежеваться со "стариками", стал всеэмигрантский съезд 1926 г., состоявшийся в Париже. На этом съезде сорвалась попытка объединить русское зарубежье. Следствием этого стало окончательное разочарование эмигрантской молодёжи в старшем поколении, которое они считали виновным в российской катастроде. Как писал один из лидеров НТС В. Д. Поремский: "Больше всего нас возмущали политические споры, которые сводились к поиску виновных в катастрофре, причём каждый сваливал вину на другого: монархисты на кадетов, кадеты на социалистов и т. д. Мы резко отгородились от всей этой эмигрантской толчеи" [20, с. 118].

Поколение "детей" стало ещё активнее искать собственный путь. К 1927 г. в нескольких странах образовались молодёжные кружки, деятельность которых носила первоначально культурно-просветительский характер. Моло- 
дёжь знакомилась с русской культурой и искусством. В этой области значительную помощь оказало поколение "отцов", среди которых можно выделить такие имена, как Г. К. Гинс, Н. О. Лосский, С. Л. Франк, Б. П. Вышеславцев, И. И. Ильин, П. Б. Струве, Н. А. Бердяев, А. Д. Билимович и многие другие.

Однако процесс эмансипации поколения "детей" стремительно развивался, и к 1929 г. можно считать влияние "отцов" полностью изжитым. Молодёжь стремилась самостоятельно разобраться в политических вопросах, так как "отцы" всё ещё находились под влиянием политического шока 1917 г. и Гражданской войны.

К 1927 г. Кружок русской национальной молодёжи в Болгарии принял решение о "выходе его на широкую дорогу общественности и о распространении своих идей среди эмиграции" [8, с. 52]. Основной идеей кружка, как позже писал один из лидеров Народно-Трудового Союза (НТС) Владимир Поремский, было "установление контакта между людьми, одинаково ощущавшими крах старых политических теорий и необходимость поисков новых путей" (Поремский В. Д. О тактике союза. Доклад, прочитанный на инструкторских курсах НТСНП. Париж, 1941. Архив НТС. Франкфурт-на-Майне. Ф. 1. П. 12. Д. 4. С. 4.). Почти сразу члены кружка начали пропагандировать свои взгляды в других местах расселения русских эмигрантов, в особенности в Южной Европе. В 1927 г. открылись его отделения в целом ряде болгарских городов, а также в других европейских странах. В тот же период кружок был переименован в Национальный союз русской молодёжи (НСРМ).

НСРМ установил связи с родственным по духу СРНМ из Югославии, который осенью 1928 г. возглавил выходец из казаков В. М. Байдалаков. 1 сентября 1928 г. они выпустили общее обращение с призывом созвать в Белграде объединительный съезд эмигрантской молодёжи. Центрами подготовки съезда и создания общей организации стали Белград и Париж. В сентябре 1929 г. болгарский и югославский союзы объединились в Национальный союз русской молодёжи за рубежом (НСРМ) [19, с. 415].

В 1929-1930 г. инициативные группы, объединявшие "национально мыслящую" молодёжь, появились во Франции, а также в Китае и Японии. На совещании во французском городе Сен-Жульен в июне 1930 г. было принято решение созвать об̆ъединительный съезд в Белграде. Съезд прошёл с 1 по 5 июля 1930 г., поэтому 1 июля принято считать датой основания НТС. 14 делегатов из Югославии, Франции, Болгарии, Голландии, Чехословакии и Латвии собрались в небольшой "кавалерийской комнате" Русского офицерского собрания. Ими был основан объединённый Национальный Союз Русской Молодежи (НСРМ). Съезд принял общий, единый Устав, учредил Совет Союза и Исполнительное Бюро. В Совет вошли выборные руководители союзов русской молодёжи в каждой из стран и два кооптированных члена. Возглавил Совет родственник Николая II герцог С. Н. Лейхтенбергский (Франция), в Исполнительное Бюро вошли В. М. Байдалаков (председатель), А. И. Занкевич и М. Н. Хлопин (все из Югославии) [15, с. 6].

Съезд наметил программу национально-политической подготовки и принял "Идеологические положения". В этом первом программном документе НТС целями созданного Союза провозглашались:

"1. Установление твёрдой центральной власти, стоящей над партиями и классами... c. 126].

2. Установление личных свобод, равенства всех перед законами..." [5,

В "Идеологических положениях" не определена форма государственного правления, поскольку до 1991 г. солидаристы придерживались непредрешенческих позиций, допуская как республику, так и монархию. Этот вопрос откладывался ими до "будущего народного волеизъявления", и лишь после референдума 17 марта 1991 г. НТС сделал окончательный выбор в пользу президентской республики.

В национальном вопросе солидаристы с самого начала выступали за сохранение государственного единства народов России, свободных в своём развитии, и в собственном первом документе они признали за народами, входящими в состав России, "право на национальную самодеятельность". Национально-территориальная автономия, а тем более "право на самоопределение вплоть до отделения" были для них полностью неприемлемы. 
Ряды Союза быстро пополнялись. Вскоре после съезда в НСРМ вошли отделы в Польше, Бельгии, на Дальнем Востоке и группы в Прибалтике, а также шанхайская группа русской молодежи.

25-27 декабря 1931 г. в Белграде состоялся II съезд Союза, на который собрались делегаты из Бельгии, Болгарии, Литвы, Польши, Чехословакии, Франции и несколько человек из Югославии. Съезд пересмотрел Устав и переименовал организацию в Национальный Союз Нового Поколения (НСНП). Чтобы окончательно отмежеваться от "отцов", был введён возрастной ценз, согласно которому состоять в Союзе могли лишь лица, родившиеся после 1895 г. $[20$, c. 118].

Тактику организации делегаты сформулировали следующим образом:

"Признание революционных методов борьбы, до террора включительно, и всемерное участие в этой борьбе. [...] Исходя из того, что "история творится идеей", - ведение широкой пропаганды идеологии Союза" [6, с. 145].

Здесь нужно отметить, что эмигрантская молодёжь искала новые методы и пути борьбы, и заслуга новопоколенцев состоит в том, что они попытались перейти от свойственного белоэмигрантскому активизму бессмысленного террора к идейно-политической пропаганде. При этом первоначально солидаристы не исключали террористические методы и, переходя границу, брали с собой оружие, но были против низового террора.

Один из лидеров НТС Г. С. Околович, сам ходивший через советскую границу, утверждает, что солидаристы были воспитаны в убеждении, "что злом и убийством хорошего дела не построишь". По его словам, исключением являлся лишь И. В. Сталин, которого они ненавидели и готовы были уничтожить "во имя спасения тысяч и тысяч других людей" [12; 80].

Однако возможностей для ликвидации Сталина у организации не было. Даже сам переход границы был весьма сложным, нередко возникали перестрелки с советскими патрулями. По свидетельству Околовича, при переходе погибал каждый второй член НТС $[12 ; 81]$.

В то же время фрактов проведённых членами НТС террористических акций не отмечено, за исключением диверсий во время гражданской войны в Испании 1936-1939 гг.

Эту войну в русской эмиграции воспринимали как продолжение борьбы белых и красных. Новопоколенцы также сочувствовали "белым" испанцам (сторонникам Ф. Франко). Руководство Союза дало согласие члену Совета Д. М. Завжалову на участие в акциях по срыву советской помощи "красным" испанцам, рассматривая её, скорее, как школу революционной подготовки для членов НТСНП. В ходе одной из таких операций, по свидетельству Байдалакова, в ангарах была полностью уничтожена эскадрилья советских истребителей, перемещавшаяся из Москвы в Мадрид. Таких акций было несколько, но затем руководство НТСНП, взвесив чисто технический урон "красных" и угрозу потери ценных членов организации, дало команду "отставить" [6, 16-17].

На II съезде были также приняты "Инструкция работы на местах", "Тактика" и "Задачи Союза". Первоочередной задачей провозглашалась "национальная революция в России". Решением II съезда был создан закрытый сектор, просуществовавший до 1991 г.

Извлекая уроки из Гражданской войны, новопоколенцы уделяли большое внимание разработке идейно-политической альтернативы большевизму. В 1931-1935 гг. проводилась работа звеньев, семинаров, курсов, читались доклады, был написан конспект "Национально-политическая подготовка" (курс НПП) и другие пособия. С конца 1935 г. знание "Курса изучения СССР" и "Курса общетехнической подготовки" стало обязательным для всех членов Союза.

В 1931 гг. НТС приступил к созданию собственной прессы: в ряде эмигрантских изданий появилась страница Союза ("Часовой" в Брюсселе, "Россия и славянство" в Париже, "За свободу" в Варшаве, "Слово" в Харбине и "Русский голос" в Белграде). С 1932 г. в Болгарии начинает выходить ежемесячная (позже двухнедельная) газета Союза "За Россию". Тираж газеты быстро рос и к третьему номеру достиг двух тысяч экземпляров.

С 1932 г. НТС приступил к засылке своих агентов на территорию СССР. Перед ними были поставлены следующие задачи: 
1) выяснить психологическую обстановку в Советском Союзе;

2) изучить возможности для подпольной политической работы;

3) создать опорные точки для организации НТС в России.

В 1932-1934 гг. для перехода советской границы НТС использовал каналы Братства Русской Правды (БРП) и Русского общевоинского союза (РОВС). В то же время новопоколенцы решительно отмежевались от методов этих организаций, выступив против "голого активизма" и низового террора. В обращении Совета НТС "К новому поколению России", принятом в июне 1933 г., подчеркивалось: "Бесполезно убивать за тысячу верст от Москвы мелкого партийца или жечь стога сена в колхозах" [4, с. 44]. Первые попытки проникновения в СССР закончились провалом и гибелью 8 членов НТС. Этот опыт нашёл своё отражение в решениях III съезда НTC.

III съезд прошёл с 15 по 19 апреля 1934 г. в Белграде. В его работе приняли участие 13 делегатов из Бельгии, Болгарии, Польши, Франции, Чехословакии и Эстонии; члены Совета и местного Правления из Югославии и три гостя, недавно покинувшие СССР (среди них известный российский политический деятель В. В. Шульгин). Съезд завершился публичным собранием в Русском Доме перед аудиторией в 700 человек. На съезде были подведены итоги проделанной работы и сделан вывод, что Союз, действующий уже в 15 странах зарубежья, "превратился в движение". Съезд принял пять резолюций по идеологическим вопросам (единство российской нации, административное устройство, социальный вопрос, казачество, церковь), уточнил учебную программу и "Задачи Союза" [4, с. 44].

На съезде был кардинально пересмотрен Устав, что явилось отражением перестройки внутренней структуры организации. В интересах защиты от советской агентуры выборное начало было упразднено, состав Совета фриксирован с допущением кооптации. Для контроля соблюдения Устава членами Союза был предусмотрен назначаемый Советом Высший Суд Совести и Чести (ВССЧ), в новый Устав был включён пункт об обязательной сдаче экзаменов по курсу национально-политической подготовки перед принятием в действительные члены Союза.

Значительные перемены произошли и в персональном составе руководства организации. Накануне III съезда на Председателя Исполнительного бюро В. М. Байдалакова были возложены полномочия Председателя Совета. На новую должность Секретаря Исполнительного бюро на съезде был избран преподаватель и член правительства А. И. Деникина времён Гражданской войны М. А. Георгиевский, членами Исполнительного бюро стали М. Д. Хлопин и Мария Попескул.

III съезд стал поворотным пунктом в истории НТС. На этом съезде Союз был преобразован из конфедерации молодёжных объединений, представляющих разные страны русского зарубежья, в единую политическую организацию с жёсткой централизованной структурой. После III съезда вся власть внутри организации перешла к Совету и его рабочему органу Исполнительному бюро. Созданные на III съезде централизованная структура управления и самопополняющийся Совет просуществовали до конца Второй мировой войны.

Вскоре после III съезда Совет утвердил новое название: Национально-Трудовой Союз Нового Поколения (НТСНП). В 1936 г. Совет НТСНП принял эмблему Союза: трезубец (первый символ русского государства, родовой знак великого князя Владимира Святого) на бело-сине-красном фоне (цвета исторического фрлага России, с 22 августа 1991 г. официального фрлага Российской Федерации).

Солидаристы продолжали попытки проникновения на территорию CCCP. В 1935 г. трём членам Союза удалось перейти границу в Маньчжурии по нераскрытым каналам БРП на Дальнем Востоке. Они смогли достичь Москвы и завязать там политические контакты, но на обратном пути были опознаны видевшим их в Харбине железнодорожником. В сентябре того же года все трое были расстреляны в Иркутске.

Окончательно отказаться от использования каналов РОВС и БРП при проникновении на территорию СССР солидаристов заставило разоблачение "Внутренней линии". Тайная организация с таким названием была создана в недрах РОВС при участии новопоколенцев. Она действовала в Болгарии, Франции и других странах. На её членов возлагалась задача наблюдать "из- 
нутри" за всеми членами РОВС, бороться с проникновением в него враждебной агентуры, внедряться в другие эмигрантские организации. "Внутренней линии" удалось внедриться в БРП, НТС, "Лигу Обера", "Крестьянскую Россию" и прочие организации и группы.

Свидетельства Г. Е. Прилуцкого, члена НТСНП, который летом 1934 г., переходя границу по каналам РОВС, лишь чудом избежал ловушки, и другие данные о деятельности "Внутренней линии" солидаристы представили руководителям РОВС ещё в 1935 г.. Но лишь похищение председателя РОВС генерала Миллера 23 сентября 1937 г. сделало для всех очевидным предательство генерала Скоблина и других деятелей "Внутренней линии". Сам Скоблин исчез в следующую ночь [18, с. 181].

Мария Пепескул, казначей Исполнительного бюро Союза, влюбилась в Альбина Коморовского, начальника 4-го отдела РОВС, в котором многие видели одного из вдохновителей "Внутренней линии". В марте 1936 г. она не только заявила о выходе из рядов НТСНП, но и стала активным членом "Внутренней линии". Противодействуя подрывной работе, руководство НТСНП решило само внедрить во "Внутреннюю линию" своих людей. На роль осведомителей были определены рядовые члены Союза Владимир Чеботаев и Георгий Черемисов. В октябре 1937 г., когда "Внутренняя линия" решила устранить одного из лидеров НТСНП Георгиевского, эти люди приняли участие в заговоре. На квартире Чеботаева, где готовилось итоговое собрание заговорщиков, были установлены микрофоны, и весь разговор был сначала записан членами НТСНП, а потом передан в югославскую полицию. Заговорщики были арестованы 10 ноября 1937 г. После завершения следствия М. Д. Пепескул, а также завербованный ею член НТСНП А. П. Черташ были исключены из Союза и подверглись высылке из Белграда в провинцию [10, с. 147-148]. Этот опыт заставил новопоколенцев отказаться от оперативных связей с любыми эмигрантскими организациями и искать собственные пути в Россию.

Такие возможности открылись благодаря помощи начальника русского отдела польского генерального штаба Ричарда Врага. Поляков интересовали возможность подпольной политической деятельности при сталинском режиме и техника перехода границы. Солидаристы согласились на сотрудничество, поставив следующие условия:

a) сохранение политической независимости Союза;

б) отказ давать информащию разведывательного характера.

В 1938-1939 гг. члены НТСНП проникали на территорию СССР с территории Польши, а с сентября 1939 г. - с территории Румынии. Около 10 человек погибло при переходах границы, но девятерым удалось обосноваться в Советском Союзе, положив начало организации НТC внутри России.

Кроме агентуры накануне Великой Отечественной войны в СCCP засылались печатные материалы НТС. Для анализа советской печати и производства литературы в 1937 г. в Берлине была создана конспиративная база "Льдина". Она действовала при поддержке японского посольства и японской разведки. Японцы снабжали её советскими газетами и прочей литературой, а изготавливаемая пропагандистская продукция была адресована советским гражданам. Для руководства работой типографии Исполнительное бюро утвердило трёх человек: Александра Казанцева (Белград), Бориса Прянишникова (Лион) и Сергея Зезина (Берлин). Сотрудничество с японцами расценивалось, согласно Прянишникову, как позитивное и многообещающее. Однако солидаристы допустили стратегический просчёт, надеясь на возникновение в России на основании заброшенной литературы групп НТСНП, не связанных с зарубежным центром. Единственным сведением о подобных группах было сообщение московского радио от 6 декабря 1938 г. о раскрытии группы НТСНП $[6$, c. 81].

Продолжалась и внутренняя организационная работа, важным фрактором которой стали поместные съезды, проводившиеся во всех отделах. Наиболее важным можно считать IV поместный съезд в Югославии, прошедший с 31 мая по 1 июня 1936 г. На него съехалось около 150 делегатов из 23 отделений и групп Союза. Съезд обсудил идеи нащионально-трудового солидаризма, уточнил задачи и методы работы, наметил общие планы деятельности.

Тем временем ситуация в Европе и в мире становилась всё более угрожающей. В марте 1938 г. Австрия была оккупирована фашистской Германией. 
В ответ на изменившуюся обстановку Исполнительное бюро Совета НТСНП рассылает в свои отделы циркулярное письмо от 24 марта 1938 г., в котором подчёркивалось: "В случае внутренних крупных потрясений на родине, как и в случае внешнего открытого конфлликта, Союз использует открывающиеся возможности для установления единства со своим народом в его борьбе. Пути вклинения наших кадров в решающий момент - будут. Группам членов Союза должно заботиться о своей годности и готовности" [16, с. 135-136].

Агрессивность фошизма нарастала, и в августе 1938 г. Исполнительное бюро Союза решило приостановить работу Германского отдела - "не ожидая официального закрытия группы НТСНП в Германии". Такая угроза возникла после отказа солидаристов войти в профрашистское Русское национал-социалистическое движение (РНСД). Закрытие отдела германскими властями сделало бы Союз "запрещённой организацией" со всеми вытекающими последствиями для его членов. В этих условиях самороспуск оказался единственным выходом. В августе 1937 г. председатель НСНП Байдалаков освободил первого председателя Союза Лейхтенбергского от обязанностей члена Совета из-за его вступления в ряды РНСД в Германии.

Руководство НТСНП спешило использовать оставшееся время, пока не прервалась связь между группами. Только в 1938 г. в странах Европы было созвано 6 поместных съездов с участием Председателя Союза В. М. Байдалакова или Секретаря Исполнительного Бюро М. А. Георгиевского. В сентябре 1938 г. в Белграде состоялась конфиденциальная встреча Байдалакова с лидерами РОВС, на которой было заявлено о необходимости сотрудничества. Стороны попытались согласовать свои действия и найти общую линию. Кроме того, в ноябре и декабре 1938 г., а также в январе 1939 г. члены Исполнительного Бюро В. М. Байдалаков, М. А. Георгиевский и К. Д. Вергун побывали в 50 группах Союза в Европе. В январе 1939 г. Председатель НТСНП В. М. Байдалаков посетил Харбин, где в качестве члена "почётного президиума" участвовал в фашистском съезде белоэмигрантов. Во время этих поездок проводились консультации с представителями местных отделений Союза, другими политическими объединениями русской эмиграции, согласовывались действия в условиях надвигавшейся войны [4, с. 47].

Итогом визитов и специальных семинаров стал трёхчасовой доклад на тему "Иллюзии и действительность", прочтённый в переполненном большом зале Русского Дома в Белграде 22 февраля 1939 г. Председателем Союза В. М. Байдалаковым. Доклад представлял собой открытое программное выступление, обращённое ко всей русской эмиграции. В этом выступлении впервые ясно и демонстративно была выражена получившая впоследствии широкий резонанс идея "Третьей силы": "... ни со Сталиным, ни с иноземными завоевателями, а со всем русским народом" [16, с. 138].

Возможность реализовать эту идею представилась уже в конце 1939 г., когда началась советско-фринляндская война, которая повлекла поголовную мобилизацию членов НСНП в Финляндии как граждан этой страны в финскую армию. Большинство из них в этой войне погибло [6, с. 23]. Но новопоколенцы отказались взять на себя "политическое водительство" "освободительной армии" в Финляндии, составленной из перебежчиков, пленных и русских эмигрантов, предложенное премьер-министром Франции Даладье через бывшего министра финансов Временного правительства России М. И. Терещенко. Руководство Союза посчитало, что эта авантюра обречена на провал. В то же время солидаристы попытались облегчить судьбу попавших в плен к финнам красноармейцев. Об этом, а также о необходимости внести в войну пропагандистско-политические моменты один из руководителей Французского отдела НТСНП А. П. Столыпин (сын премьер-министра России в 1906-1911 гг. П. А. Столыпина) вёл переписку с маршалом К. Маннергеймом [6, с. 24-25].

Тем временем в Европе уже шла Вторая мировая война. Государствами фрашистского блока были оккупированы Австрия, Чехословакия, Албания, Польша. Ситуация становилась всё более непредсказуемой и опасной. В этих условиях новопоколенцы решили переправить из Белграда на Запад группу Союза под руководством М. А. Георгиевского, который от имени НТСНП отказался в 1938 г. от сотрудничества с гитлеровцами и попал в их чёрный список. Перед группой Георгиевского была поставлена задача представлять на За- 
паде интересы Союза, а в случае гибели или ареста руководства возглавить организацию.

В это время в Белград приехал негласный посланник польского правительства генерала Сикорского в Лондоне. Вместе с ним был выработан договор о сотрудничестве НТСНП и польского правительства в изгнании. В договоре был пункт о переброске полномочной делегации НТСНП в Англию или США. Но пока текст договора отправлялся в Англию, пока его там одобряли, обстановка вновь резко изменилась.

6 апреля 1941 г. без объявления войны югославскую границу пересекли немецкие, итальянские и венгерские дивизии. Они двигались со всех сторон: из Австрии, Италии, Венгрии, Болгарии и Албании. Так Югославия, в которой размещалась штаб-квартира Союза, была оккупирована. Георгиевский был вынужден выйти из Исполнительного бюро и укрыться на территории так называемой "Независимой Державы Хорватской" (НДХ), где, несмотря на фальшивую независимость, было безопаснее, чем в оккупированной немцами Сербии.

Вскоре все основные центры НТСНП оказались на оккупированной территории, связь часто отсутствовала, и Байдалаков передал полномочия исполняющего обязанности Председателя Союза А. Э. Вюрглеру, возглавлявшему во второй половине 30-х отдел НТСНП в Польше. Кроме Вюрглера руководство Союза осуществляли Д. В. Брунст, который возглавил объединенные в один бельгийский, фрранцузский и чехословацкий отделы (все официально "закрытые"), и видный идеолог НТСНП В. Д. Поремский. Фактически, в действие вступило запасное Исполнительное Бюро.

Вюрглер удалил из названия НТСНП последние два слова, что впоследствии подтвердил своим решением Совет Союза, отменивший перед самой войной возрастной ценз. Таким образом, солидаристы вступили в Великую Отечественную войну, открывшую новый этап их истории, под названием Национально-Трудовой Союз (НТС).

Подводя итоги, нужно отметить, что в довоенный период (1924-1941) происходило становление НТС. Союз организационно оформился, пройдя сложный путь от разрозненных кружков русской молодёжи до широкой конфедерации молодёжных объединений, представляющих разные страны русского зарубежья, а затем трансформировавшись в единую политическую организацию с жёсткой централизованной структурой. В этот период были заложены основы идеологии солидаризма, но Вторая мировая война помешала закончить начатую в 1934 г. работу над программой.

Предпосылками появления на политической арене движения российских солидаристов стало недовольство русской эмиграции своим маргинальным положением и нежелание смириться с победой большевиков в Гражданской войне. Наиболее радикальные позиции занимала молодёжь, не желавшая ждать лучших времён и винившая "отцов" в русской катастроде.

В довоенном периоде можно выделить три основных этапа:

1. 1924-1930 гг. - от создания первого кружка русской национальной молодёжи до объединительного съезда.

2. 1930-1934 гг. - от I Съезда НТС, объединившего молодёжные организации русского зарубежья из разных стран, до III Съезда, преобразовавшего широкую конфедерацию молодёжных объединений, представляющих разные страны русского зарубежья, в единую политическую организацию с жёсткой централизованной структурой.

3. 1934-1941 гг. - от централизации до начала Великой Отечественной войны.

Целью новой организации, доставшейся ей в наследство от Белого движения, стало свержение власти большевиков или "национальная революция в России". Даже будущая форма правления была для них непринципиальна. Однако чёткой стратегии по выполнению своей главной цели у организации не было.

Эмигрантская молодёжь искала новые методы и пути борьбы, и заслуга новопоколенцев состоит в том, что они попытались перейти от свойственного белоэмигрантскому активизму бессмысленного террора к идейно-политической пропаганде. В то же время, выступая против низового террора, члены HТC готовы были уничтожить Сталина и при переходах границы брали с со- 
бой оружие. Фактов проведённых ими террористических акций не отмечено, за исключением диверсий во время гражданской войны в Испании 1936-1939 гг.

Основной упор делался на идейную борьбу и пропаганду. Новопоколенцы уделяли большое внимание разработке идейно-политической альтернативы большевизму, занимались самообразованием и пропагандой своих взглядов в эмиграции. С конца 1935 г. знание "Курса изучения ССCP" и "Курса общетехнической подготовки" стало обязательным для всех членов Союза. Солидаристы начали работу над созданием собственной прессы и базы для пропаганды на СССР. Однако у них оказалось явно недостаточно сил и средств для выполнения взятых на себя задач.

К концу 1938 г. (последний год перед обрывом связи) Союз насчитывал 200 групп в 17 странах русского зарубежья, однако общая численность организации накануне Второй мировой войны составляла лишь около 1570 человек (от 0,1 до 0,2 \% всех русских, включая меньшинства, живших тогда за пределами СССР). Из этих 1570 человек около 930 жили в Восточной Европе, позже занятой Советской армией, и 110 - на Дальнем Востоке. В Западной Европе проживали около 440 человек, а 80 - на Ближнем Востоке, в США и Австралии [11, с. 124].

По зарубежным масштабам НТС был довольно крупной организацией. Но в сравнении со 170-милионным населением СССР, на которое солидаристы пытались оказать свое идейно-политическое влияние, количество членов организации было крайне незначительным. В условиях, когда самый мощный в истории карательный аппарат подавлял в зародыше любое инакомыслие, идейная пропаганда не давала видимых результатов. Великая Отечественная война кардинально изменила ситуацию. Она породила новые трудности, но, одновременно, открыла для солидаристов новые возможности.

\section{Литература}

1. Алексеев Д. Ю. Народно-Трудовой Союз российских солидаристов в борьбе против тоталитарного режима автореферат дис.... кандидата политических наук / Дальневосточ. Гос. Ун-т. Владивосток, 1998.

2. Алексеев Д. Ю., Печерица В. Ф. Российский солидаризм: теория, история и современность. Уссурийск: издательство УГПИ, 2000. 184 с.

3. Алексеев Д. Ю. Российский солидаризм: теория, практика, люди. Владивосток: Издательство ТГЭУ, 2010. 272 с.

4. Алексеев Д. Ю. Российские солидаристы в борьбе против тоталитарного режима. Саарбрюккен.: LAP, 2011. 240 с.

5. Артёмов А. Н. Программа НТС и российская государственность // Посев.1991. № 2. C. 126 .

6. Байдалаков В. М. Да возвеличится Россия. Да гибнут наши имена... Воспоминания председателя НТС. 1930-1960 гг. М., 2002. 124 с.

7. В поисках истины. Пути и судьбы второй эмиграции. Сб. статей и документов. / Под общей редакцией А. В. Попова. М., РГГУ, 1997. 376 с.

8. Злобин Ф. З. Национальный союз русской молодежи за рубежом (история и идеология)// За Россию [София]. 1930. № 1. С. 51-54.

9. Каневская Г. И. "Мы ещё мечтаем о России..." История русской диаспоры в Австралии. Владивосток: Издательство ДВГУ, 2010. 372 с.

10. Климович Л. В. Народно-Трудовой Союз российских солидаристов: ранние страницы истории // Неприкосновенный запас, 2013, №5. С.139-156.

11. НТС: Мысль и дело 1930-2000. М.: Посев, 2000. 128 с.

12. Околович Г. С. Быть с народом... (интервью журналу "Посев") // От Зарубежья до Москвы. Народно-Трудовой Союз (НТС) в воспоминаниях и документах. 1924-2014. М.: НП "Посев", 2014. 384 с.

13. От Зарубежья до Москвы. Народно-Трудовой Союз (НTC) в воспоминаниях и документах.1924-2014. М.: Посев, 2014. 384 с.

14. Пушкарёв Б. С. НТС в истории российского Сопротивления // От Зарубежья до Москвы. Народно-Трудовой Союз (НТС) в воспоминаниях и документах. 1924-2014. М.: НП "Посев", 2014. 384 с.

15. Съезды 30-х годов // Посев. 1996. №4. С. 6-10.

16. Трушнович Я. А. Первый год войны // Посев. 1991. № 2. С. 135-138.

17. Цурганов Ю. С. Народно-Трудовой Союз (НТС). Ступенчатый снос диктатуры // Русское зарубежье: история и современность. Сборник статей. РАН. ИНИОН. Центр комплексных исследований русской эмиграции; ред.- сост. вып. Мухачёв Ю. В., Петрова Т. Г. М., 2016. С. $35-58$. 
18. Шкаренков Л. К. Агония белой эмиграции. 2-е издание, исправленное и дополненное. М.: Мысль 1986. 272 с.

19. Эмиграция и репатриация в России. В. А. Ионцев, Н. М. Лебедева, М. В. Назаров, А. В. Окороков. М.: Попечительство о нуждах российских репатриантов, 2001. $490 \mathrm{c.}$

20. Яковлев Н. Н. ЦРУ против СССР. М.: Правда, 1983. 464 с.

\section{Транслитерация по ГОСТ 7.79-2000 система Б}

1. Alekseev D. Yu. Narodno-Trudovoj Soyuz rossijskikh solidaristov v bor'be protiv totalitarnogo rezhima avtoreferat dis.... kandidata politicheskikh nauk / Dal'nevostoch. Gos. Un-t. Vladivostok, 1998.

2. Alekseev D. Yu., Pecheritsa V. F. Rossijskij solidarizm: teoriya, istoriya i sovremennost'. Ussurijsk: izdatel'stvo UGPI, 2000. $184 \mathrm{~s}$.

3. Alekseev D. Yu. Rossijskij solidarizm: teoriya, praktika, lyudi. Vladivostok: Izdatel'stvo TGEHU, 2010. $272 \mathrm{~s}$.

4. Alekseev D. Yu. Rossijskie solidaristy v bor'be protiv totalitarnogo rezhima. Saarbryukken.: LAP, 2011. $240 \mathrm{~s}$.

5. Artyomov A. N. Programma NTS i rossijskaya gosudarstvennost' // Posev.1991. № 2. S. 126.

6. Bajdalakov V. M. Da vozvelichitsya Rossiya. Da gibnut nashi imena... Vospominaniya predsedatelya NTS. 1930-1960 gg. M., 2002. 124 s.

7. V poiskakh istiny. Puti i sud'by vtoroj ehmigratsii. Sb. statej i dokumentov. / Pod obshhej redaktsiej A. V. Popova. M., RGGU, 1997. 376 s.

8. Zlobin F. Z. Natsional'nyj soyuz russkoj molodezhi za rubezhom (istoriya i ideologiya)// Za Rossiyu [Sofiya]. 1930. № 1. S. 51-54.

9. Kanevskaya G. I. "My eshhyo mechtaem o Rossii..." Istoriya russkoj diaspory v Avstralii. Vladivostok: Izdatel'stvo DVGU, 2010. $372 \mathrm{~s}$.

10. Klimovich L. V. Narodno-Trudovoj Soyuz rossijskikh solidaristov: rannie stranitsy istorii // Neprikosnovennyj zapas, 2013, №5. S.139-156.

11. NTS: Mysl' i delo 1930-2000. M.: Posev, 2000. 128 s.

12. Okolovich G. S. Byt' s narodom... (interv'yu zhurnalu "Posev") // Ot Zarubezh'ya do Moskvy. Narodno-Trudovoj Soyuz (NTS) v vospominaniyakh i dokumentakh. 19242014. M.: NP "Posev", 2014. 384 s.

13. Ot Zarubezh'ya do Moskvy. Narodno-Trudovoj Soyuz (NTS) v vospominaniyakh i dokumentakh.1924-2014. M.: Posev, 2014. $384 \mathrm{~s}$.

14. Pushkaryov B. S. NTS v istorii rossijskogo Soprotivleniya // Ot Zarubezh'ya do Moskvy. Narodno-Trudovoj Soyuz (NTS) v vospominaniyakh i dokumentakh. 1924-2014. M.: NP "Posev", 2014. $384 \mathrm{~s}$.

15. S"ezdy 30-kh godov // Posev. 1996. №4. S. 6-10.

16. Trushnovich Ya. A. Pervyj god vojny // Posev. 1991. № 2. S. 135-138.

17. Tsurganov Yu. S. Narodno-Trudovoj Soyuz (NTS). Stupenchatyj snos diktatury // Russkoe zarubezh'e: istoriya i sovremennost'. Sbornik statej. RAN. INION. TSentr kompleksnykh issledovanij russkoj ehmigratsii; red.- sost. vyp. Mukhachyov Yu. V., Petrova T. G. M., 2016. S. 35-58.

18. Shkarenkov L. K. Agoniya beloj ehmigratsii. 2-e izdanie, ispravlennoe i dopolnennoe. M.: Mysl' 1986. 272 s.

19. Ehmigratsiya i repatriatsiya v Rossii. V. A. Iontsev, N. M. Lebedeva, M. V. Nazarov, A. V. Okorokov. M.: Popechitel'stvo o nuzhdakh rossijskikh repatriantov, 2001. $490 \mathrm{~s}$.

20. Yakovlev N. N. TSRU protiv SSSR. M.: Pravda, 1983. 464 s. 


\section{Алексеев Д. Ю. Возникновение и становление Народно-Трудового Сою- за российских солидаристов.}

На основе различных данных анализируется довоенный период деятельности старейшей политической организации из непрерывно существующих в России Народно-Трудового Союза российских солидаристов (НТC). Автором рассматривается сложный путь солидаристов от разрозненных кружков русской молодёжи до широкой конфедерации молодёжных объединений, представляющих разные страны русского зарубежья, а затем трансформация в единую политическую организацию с жёсткой централизованной структурой, а также методы их политической борьбы.

Ключевые слова: НТС, Народно-Трудовой Союз российских солидаристов, политические организащии, русская эмиграиия

Alekseev D. Yu. The emergence and formation of the People's Labor Union of Russian solidarists.

Based on various data, the pre-war period of activity of the oldest political organization from the People's Labor Union of Russian Solidarists (NTS) continuously existing in Russia is analyzed. The author examines the difficult path of solidarists from scattered circles of Russian youth to a wide confederation of youth associations representing different countries of the Russian foreign countries, and then transformation into a single political organization with a rigid centralized structure, as well as methods of their political struggle.

Key words: NTS, People's Labor Union of Russian solidarists, political organizations, Russian emigration

Для цитирования: Алексеев Д. Ю. Возникновение и становление Народно-Трудового Союза российских солидаристов // Ойкумена. Регионоведческие исследования. 2020. № 1. C. 150-160. DOI: 10.24866/1998-6785/2020-1/150-160

For citation: Alekseev D. Yu. The emergence and formation of the People's Labor Union of Russian solidarists // Ojkumena. Regional researches. 2020. № 1. P. 150-160. DOI: 10.24866/1998$6785 / 2020-1 / 150-160$ 


\section{Человек с горящим сердцем: к 80-летию профессора А. П. Деревянко}

Об Алексее Пантелеевиче Деревянко трудно говорить в прошедшем времени. Память о нём жива, осязаема. Его книги, публикации, советы - всё осталось людям. Вклад в науку, отечественную историю, историю Дальнего Востока значителен.

Алексей Пантелеевич Деревянко - известный ученый, специалист в области истории российского Дальнего Востока, доктор исторических наук, профрессор, Заслуженный деятель науки Российской Федерации. Автор более 200 научных работ, в том числе четырёх индивидуальных и 20 коллективных монографий.

Родился 31 января 1940 г. в с. Козьмодемьяновке Тамбовского района Амурской области. В трудные военные и послевоенные годы семье, в которой воспитывалось трое детей, приходилось нелегко. Отец, Пантелей Алексеевич, работал бригадиром плотницкой артели, мать, Евдокия Семеновна, - в колхозе. Братья - Борис, Алексей и Анатолий - с раннего возраста познали труд, все получили высшее образование. Старший, Борис, стал авторитетным инженером, младший, Анатолий, - известным археологом, академиком РАН.

Алексей после окончания Дальневосточного политехнического института и службы в армии был приглашён на преподавательскую работу в ДВПИ (Дальневосточный политехнический институт). В этот период он познакомился с двумя видными учёными-историками - Алексеем Павловичем Окладниковым и Андреем Ивановичем Крушановым. В 1969 г. Алексей Пантелеевич поступил в аспирантуру Института истории, археологии и этнографии народов Дальнего Востока. Здесь он защитил кандидатскую (1972) и докторскую (1984) диссертации. Первая была посвящена подготовке инженерно-технических кадров на Дальнем Востоке СССР в 1959-1965 гг., а вторая - историческому опыту строительства Байкало-Амурской железнодорожной магистрали в 1974-1982 гг. В институте, который стал для него родным домом, А. П. Деревянко прошёл путь от младшего научного сотрудника до заместителя директора, создателя научной школы.

Самыми плодотворными для ученого стали 1990-е гг. Он исследовал историю освоения российского Дальнего Востока, историю промышленного развития региона, процесс развития Приморья на рубеже третьего тысячелетия, события на озере Хасан 1938 г., политические репрессии, победу над фашизмом, ГУЛАГ НКВД и его роль в производственно-хозяйственной деятельности СССР, историю академической науки и др.

Важное направление его деятельности - руководство подготовкой Приморской краевой книги памяти защитников Отечества, погибших в 19411945 гг., а также создание Книги памяти жертв политических репрессий. Житейская мудрость Алексея Пантелеевича, наблюдательность, увлечённость работой и широта знаний проявлялась ежедневно. Он обладал опытом и эрудицией в вопросах организации работы над Книгой Памяти. "Приморская краевая книга памяти защитников Отечества, погибших в годы Великой Отечественной войны (1941-1945 гг.)" признана одной из лучших в России, а

(C) Шабельникова Н. А., Усов А. В., 2020

ШАБЕЛЬНИКОВА Наталья Алексеевна, д-р ист. наук, профессор, профессор кафедры гуманитарных дисциплин Владивостокского филиала Дальневосточного юридического института МВД России (2. Владивосток). E-mail: nhistorik@mail.ru

УСОВ Алексей Вячеславович, канд. ист. наук, доцент кафедры государственно-правовых и гражданско-правовых дисциплин Владивостокского филиала Дальневосточного юридического института МВД России (е. Владивосток). E-mail: 101-mvd@mail.ru 


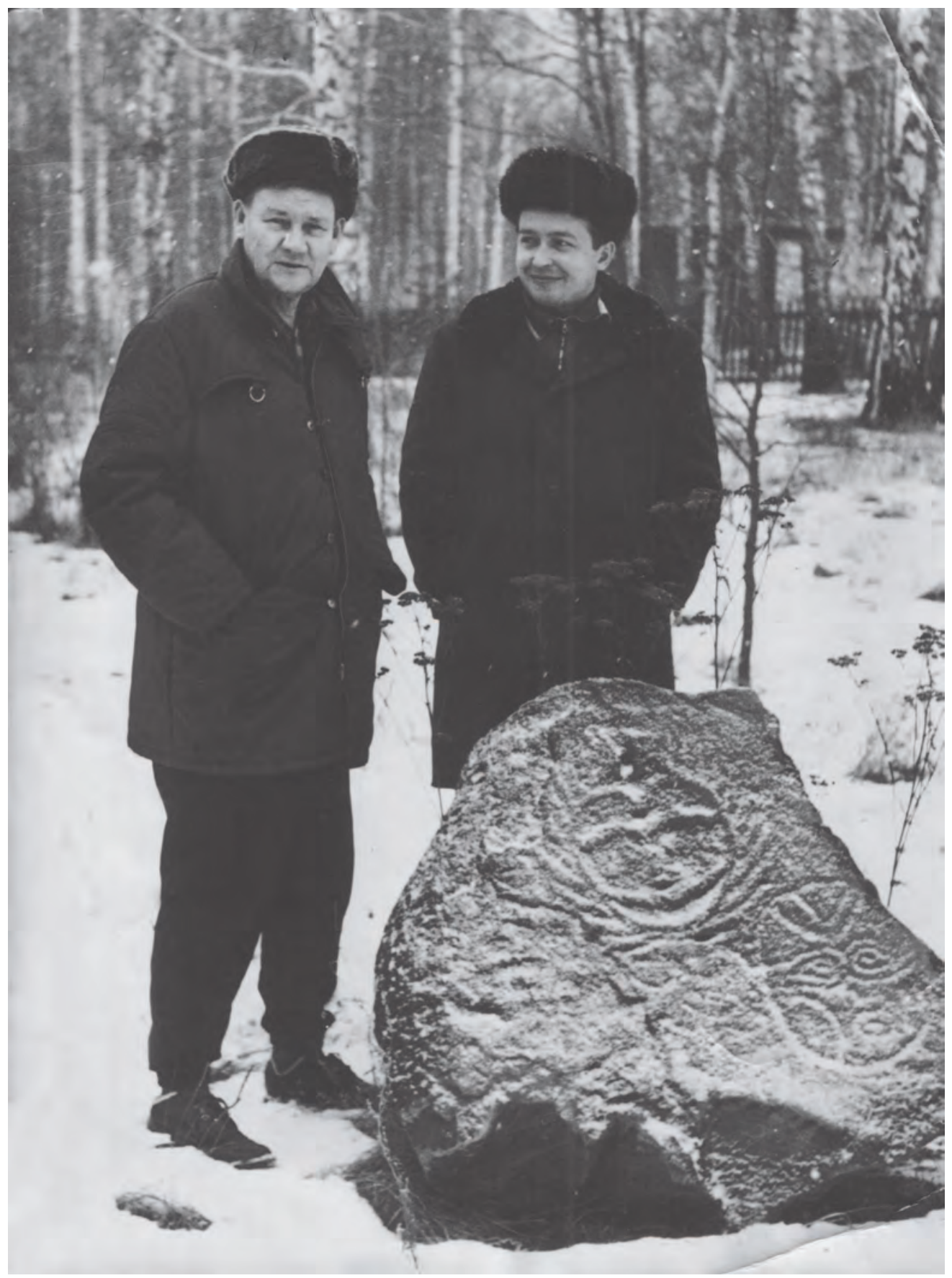

Фото. 1. "Гранит науки"

(Алексей Пантелеевич Деревянко с академиком Алексеем Павловичем Окладниковым, 1970-е гг.)

А. П. Деревянко, как её главный редактор, награждён Грамотой Правительства Российской Федерации.

Алексей Пантелеевич поддерживал тесные контакты с высшими учебными заведениями Дальневосточного региона. Неоднократно являлся председателем государственных экзаменационных комиссий, руководил подготовкой дипломников и аспирантов в различных вузах Дальнего Востока. Им 


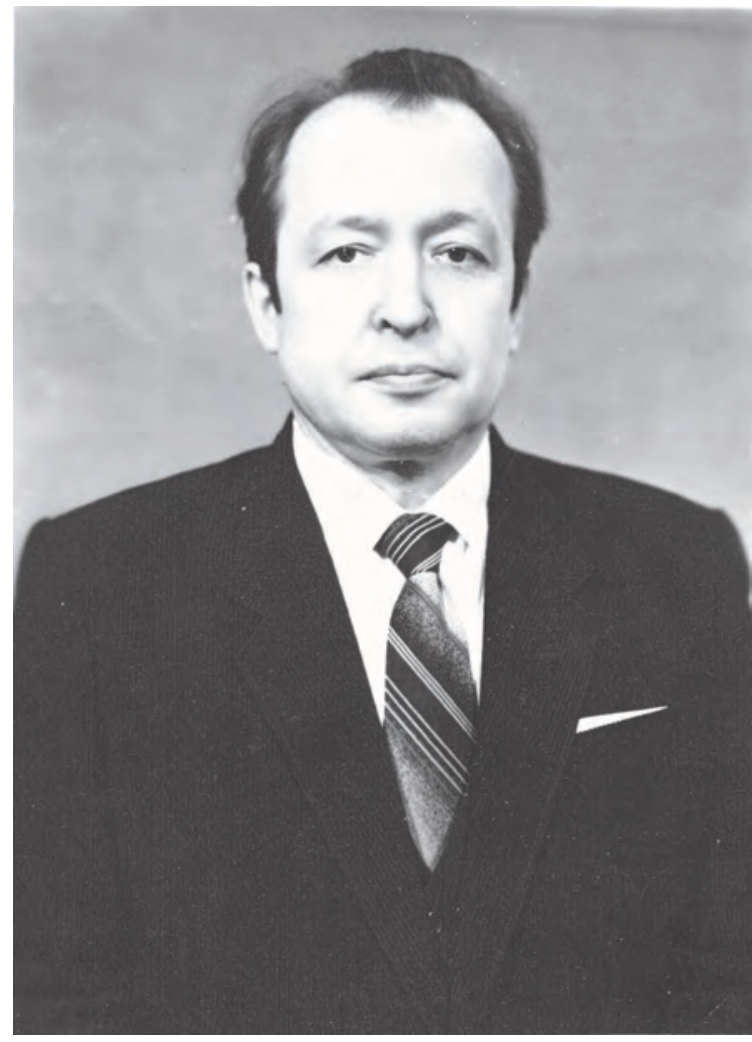

Фото. 2. А. П. Деревянко.

было написано в соавторстве несколько учебных пособий по отечественной истории, а в 1998 г. совместно с Н. А. Шабельниковой опубликовано учебное пособие "История России с древнейших времен до конца XX века". Книга получила гриф Министерства образования Российской Федерации, несколько раз переиздавалась (в том числе и в центральных издательствах).

А. П. Деревянко отдавал массу сил и энергии подготовке кадров высшей квалификации. Многие годы он входил в состав диссертационного совета в Институте истории, археологии и этнографиии ДВО РАН, был членом диссертационного совета по истории науки и техники в ДВГТУ, являлся создателем и руководителем двух диссертационных советов по историческим наукам - с 1995 по 2000 г. кандидатского совета в Дальневосточном государственном техническом университете, а с 2001 г.-председателем докторского совета в Дальневосточном государственном университете. Являлся активным

членом Профрессорского клуба.

Докторский совет в Дальневосточном государственном университете объединял людей творческих, искренне преданных науке и любимому делу. Единомышленниками и друзьями А. П. Деревянко были В. В. Сонин, К. Ф. Лыков, О. П. Еланцева. Добрыми советчиками и надёжными товарищами Е. В. Ермакова, В. Ф. Печерица и другие. Под его руководством было защищено более 20 докторских и кандидатских диссертаций.

Алексей Пантелеевич часто бывал на родине - в Амурской области. Тесные узы сотрудничества и дружбы связывали его с коллегами из Благовещенского педагогического университета и Амурского государственного университета. В них проводились международные научные конференции, объединённые общей темой изучения исторического опыта освоения Дальнего Востока. У истоков этой важной темы стоял А. П. Деревянко. Его личное участие, доклады, дружеские советы были огромным вкладом в общее дело. Благодаря кипучей энергии этот яркий человек собрал большой круг единомышленников - А. Д. Плутенко, А. П. Забияко, Ю. П. Сергиенко, Н. А. Шиндялов, И. В. Бумбар и др. Была у Алексея Пантелеевича любимая фраза "Встретил хорошего, интересного человека - приобрёл, расстался - потерял". Как много получали люди от общения с ним и как много потеряли...

Высокие заслуги перед наукой и обществом А. П. Деревянко отмечены правительственными наградами. Алексей Пантелеевич награждён несколькими медалями, правительственными грамотами. 19 июля 2001 г. Указом Президента Российской Федерации Алексею Пантелеевичу Деревянко было присвоено звание "Заслуженный деятель науки Российской Федерации".

Без преувеличения можно отметить, что Алексей Пантелеевич был человеком отважным, не любил искажённых толкований, не терпел лжи. Не случайно на презентации его книги "Российское Приморье на рубеже третьего тысячелетия" в музее им. В. К. Арсеньева присутствующий там бывший 


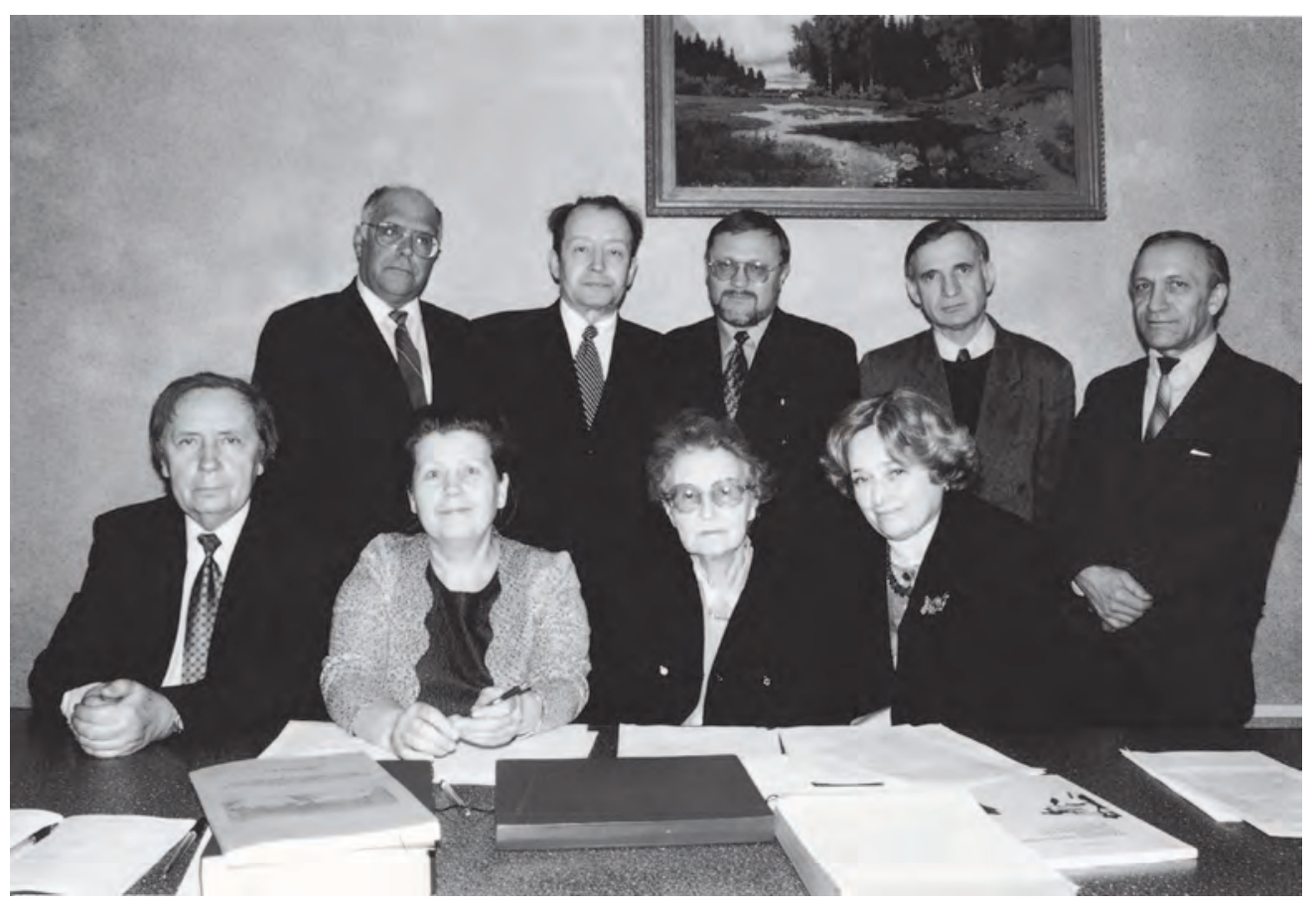

Фото. 3. Диссертационный совет Дальневосточного государственного университета (ДВГУ) по отечественной и всеобщей истории, 2002 г.

первый секретарь ЦК КПСС Приморского края В. П. Ломакин сказал: "Вы, Алексей Пантелеевич, смелый человек...", - и эти слова о многом говорят.

Алексей Пантелеевич обладал огромной работоспособностью, никогда не жалел себя. Удивляла и восхищала разносторонность его взглядов. В то же время он мог быть очень лояльным, никогда не давил на собеседника своим авторитетом, не добивался обязательного признания своего мнения; терпеливо, с уважением выслушивал собеседника. В гигантской работе он постоянно ощущал поддержку семьи и близких людей.

По своему характеру Алексей Пантелеевич был человеком очень доброжелательным, контактным, коммуникабельным и поэтому имел широкий круг знакомых в самых различных сфрерах: науке, образовании, культуре, а также в советских и партийных органах (не только Приморского края, но и всего Дальнего Востока и страны в целом). Регулярно общался он и с руководителями ведущих отраслей промышленности региона, с представителями военно-промышленного комплекса, органов УВД и ФСБ, статистических управлений, что, несомненно, способствовало значительному расширению базы проводимых исследований за счёт широкого круга источников.

К Алексею Пантелеевичу всегда тянулись люди: в его кабинете часто не смолкал телефон, почти всегда находились посетители - иностранные учёные, работники академических институтов и вузов региона и страны, аспиранты, соискатели, студенты. Он любил людей и с удовольствием им помогал, многим и многим людям "дал путёвку в жизнь".

Алексей Пантелеевич всегда стремился к тому, чтобы сотрудники его сектора постоянно работали над повышением своего профессионального уровня и квалификации: своевременно сдавали экзамены кандидатского минимума, принимали не формальное, а вполне реальное и активное участие в работе институтского философрско-методологического семинара, выступали с докладами и сообщениями на конференциях, осваивали новые методы работы с источниками. Наряду с административными методами руководства чаще всего применял метод убеждения, стимулируя аспирантов вопросами: "Когда будет готов полный текст диссертации?", "Когда будем читать Вашу монографию?", "Будет ли готова статья к сроку?". При этом всегда интересовался, 

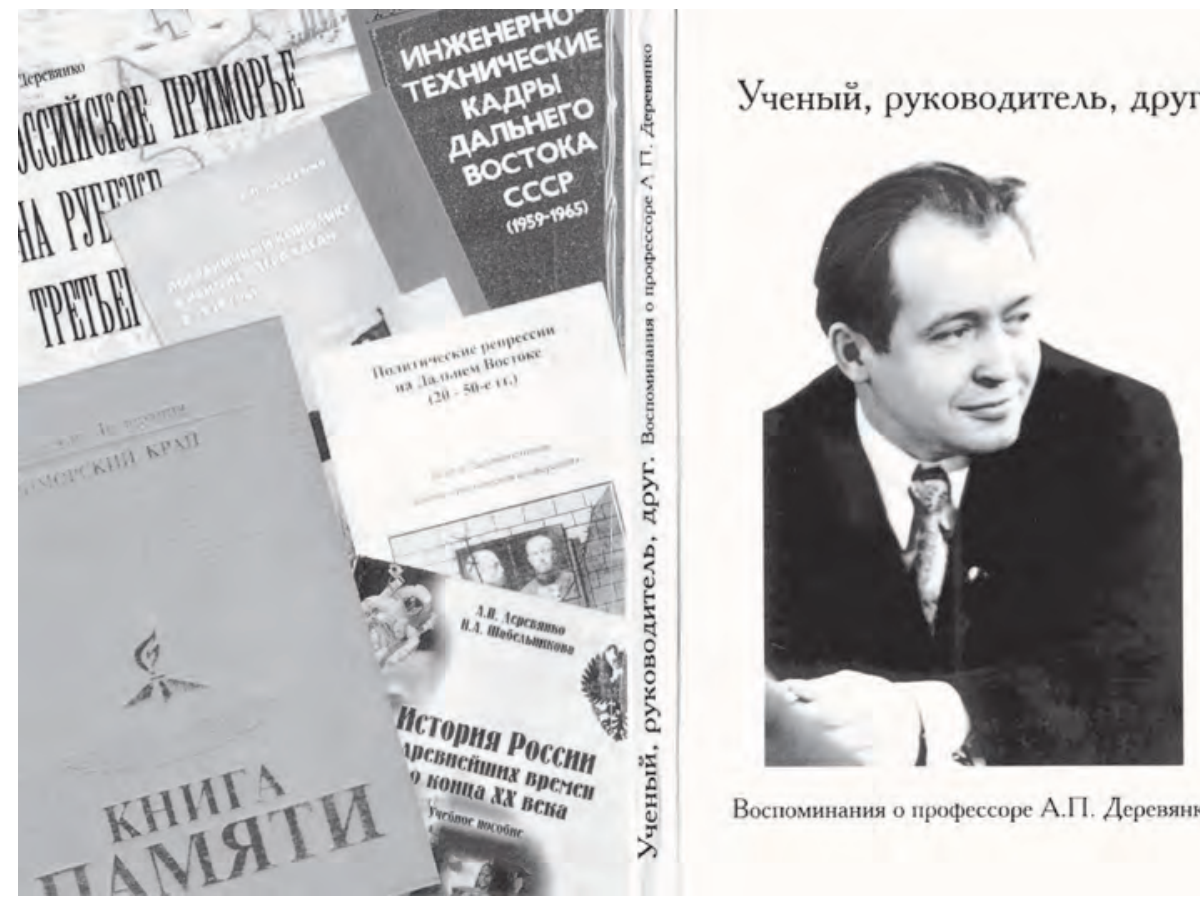

Воспоминания о профессоре А.П. Деревянко

Фото. 4. Обложка книги "Руководитель. Друг. Ученый. Воспоминания о профессоре А. П. Деревянко".

какие трудности возникают в работе, нередко давал конструктивные советы в плане обобщения и систематизации материалов, построения оптимальной структуры будущей книги, методики исследования, нацеливал на высококачественные конечные результаты.

Алексей Пантелеевич был хорошим, очень умелым организатором, требовательным руководителем и в то же время оставался мягким, добрым и отзывчивым человеком, с большим чувством юмора. Он всегда интересовался не только ходом научных изысканий своих учеников, но и простыми житейскими делами, домашними семейными заботами, был знаком и поддерживал добрые отношения с ближайшими родственниками своих сотрудников.

Природный оптимизм, любовь близких, радость сотрудничества с коллегами и учениками позволили Алексею Пантелеевичу даже в непростых условиях добиваться высочайших научных результатов. Он был полон творческих планов и надежд. Жизнь оборвалась в самом разгаре. 3 сентября 2002 г. его не стало.

Целеустремленный, настойчивый и последовательный, Алексей Пантелеевич сочетал в себе отзывчивость, доброту, был мудрым руководителем и надёжным другом. В каждое дело, за которое он брался, всегда вкладывал частичку своего сердца, горячо переживая недочёты и радуясь каждому успеху. Неутомимым исследователем, жизнелюбом и доброжелательным человеком - таким помнят Алексея Пантелеевича его коллеги и ученики. 
Шабельникова Н. А., Усов А. В. Человек с горящим сердцем: к 80-летию профессора А. П. Деревянко.

В статье рассматривается творческий путь А. П. Деревянко, доктора исторических наук, профессора, Заслуженного деятеля науки Российской Федерации - более трёх десятилетий посвятившего изучению истории Дальневосточного региона. Анализируется вклад Алексея Пантелеевича - учёного, педагога, умелого организатора в развитие науки и образования на Дальнем Востоке России.

Ключевые слова: А. П. Деревянко, наука, образование, история, Дальний Восток, Россия

Shabelnikova N. A., Usov A. V. A man with a burning heart: to the 80th anniversary of professor A. P. Derevyanko.

The article considers the creative path of A. P. Derevyanko doctor of historical Sciences, Professor, Honored scientist of the Russian Federation-more than three decades devoted to the study of the history of the far East region. The article analyzes the contribution of Alexey Panteleevich-a scientist, teacher, skillful organizer in the development of science and education in the far East of Russia.

Key words: A. P. Derevyanko, science, education, history, Far East, Russia

Для цитирования: Shabelnikova N. A., Usov A. V. A man with a burning heart: to the 80th anniversary of professor A. P. Derevyanko // Ойкумена. Регионоведческие исследования. 2020. № 1. C. 161-166. DOI: 10.24866/1998-6785/2020-1/161-166

For citation: Shabelnikova N. A., Usov A. V. A man with a burning heart: to the 80th anniversary of professor A. P. Derevyanko // Ojkumena. Regional researches. 2020. № 1. P. 161-166. DOI: $10.24866 / 1998-6785 / 2020-1 / 161-166$ 
Римская Татьяна Григорьевна (главный редактор) - кандидат исторических наук, доцент (2. Находка)

Барбенко Ярослав Александрович - кандидат исторических наук, доцент кафедры политологии Дальневосточного федерального университета (2. Владивосток)

Бурлаков Виктор Алексеевич - кандидат политических наук, доцент департамента коммуникации и медиа Дальневосточного федерального университета (2. Владивосток)

Винокурова Анна Викторовна - кандидат социологических наук, доцент департамента социальных наук Дальневосточного федерального университета (2. Владивосток)

Ганопольский Михаил Григорьевич - доктор философских наук, профессор, главный научный сотрудник Института проблем освоения Севера СО РАН (2. Тюмень)

Григоричев Константин Вадимович - доктор социологических наук, доцент, проректор по научной работе и международной деятельности Иркутского государственного университета (2. Иркутск)

Демьяненко Александр Николаевич - доктор географических наук, профессор, главный научный сотрудник Института экономических исследований ДВО РАН (2. Хабаровск)

Дударёнок Светлана Михайловна - доктор исторических наук, кандидат философских наук, профессор департамента истории и археологии Дальневосточного федерального университета (г. Владивосток)

Журбей Евгений Викторович (ответственный редактор) - кандидат исторических наук, доцент кафедры Тихоокеанской Азии Дальневосточного федерального университета (с. Владивосток)

Золотухин Иван Николаевич - кандидат политических наук, доцент кафедры международных отношений Дальневосточного федерального университета (г. Владивосток)

Караман Вадим Николаевич - кандидат исторических наук, зав. библиотекой Музея истории Дальнего Востока имени В. К. Арсеньева (2. Владивосток)

Киреев Антон Александрович - кандидат политических наук, доцент кафедры политологии Дальневосточного федерального университета (2. Владивосток)

Кожевников Владимир Васильевич - кандидат исторических наук, профессор кафедры страноведения Дальневосточного федерального университета (2. Владивосток)

Кристофферсен Гайе - Ph.D., профессор Университета Джона Хопкинса (2. Нанкин, КНР)

Кузнецов Анатолий Михайлович - доктор исторических наук, профессор кафедры международных отношений Дальневосточного федерального университета (2. Владивосток)

Латушко Юрий Викторович - кандидат исторических наук, заведующий Центром островной и прибрежной антропологии АТР Института истории, археологии и этнографии народов Дальнего Востока ДВО РАН (2. Владивосток)

Лебедева Марина Михайловна - доктор политических наук, кандидат психологических наук, профессор, заведующий кафедрой мировых политических процессов Московского государственного института международных отношений (Университета) МИД России (2. Москва)

Литошенко Денис Александрович - кандидат исторических наук, доцент кафедры истории, политологии и государственно-правовых дисциплин юридического факультета Морской академии Морского государственного университета им. адм. Г. И. Невельского (г. Владивосток)

Лукин Артем Леонидович - кандидат политических наук, доцент кафедры международных отношений Дальневосточного федерального университета (2. Владивосток)

Наумов Юрий Анатольевич - кандидат геолого-минералогических наук, доктор географических наук, член-корреспондент Международной академии наук экологии и безопасности жизнедеятельности, доцент филиала Владивостокского государственного университета экономики и сервиса в г. Находка

Рыжова Наталья Петровна - доктор экономических наук, заведующий Приморской лабораторией экономического развития и сотрудничества Института экономических исследований ДВО РАН, профессор Академического департамента Дальневосточного федерального университета (2. Владивосток)

Севастьянов Сергей Витальевич - доктор политических наук, профессор кафедры международных отношений Дальневосточного федерального университета (2. Владивосток)

Филипова Александра Геннадьевна - доктор социологических наук, профессор департамента социальных наук Дальневосточного федерального университета (2. Владивосток)

Шестак Ольга Игоревна - кандидат исторических наук, доцент, начальник научного управления Дальневосточного государственного технического рыбохозяйственного университета (2. Владивосток)

Шин Беом-Шик - Ph.D., профессор кафедры политических наук и международных отношений Сеульского национального университета (2. Сеул, Республика Корея)

Широ Сасаки - Ph.D., профессор кафедры передовых исследований в антропологии Национального музея этнологии, директор Национального музея культуры айнов (2. Сuраой, Япония)

Ячин Сергей Евгеньевич - доктор философских наук, профессор департамента философии и религиоведения Дальневосточного федерального университета (2. Владивосток) 


\section{К читателям}

Редакция извещает читателей о возможности подписки на журнал "Ойкумена. Регионоведческие исследования".

Подписка принимается во всех почтовых отделениях.

Информацию о стоимости и условиях подписки Вы можете найти в Объединенном каталоге "Пресса России" (том 1. Газеты и журналы).

Подписной индекс журнала - 42354.

Кроме того, подписка на журнал может быть оформлена в сети Интернет. Для того чтобы оформить подписку через Интернет, Вы можете зайти на начальную страницу сайта "Ойкумены" (www.ojkum.ru) и перейти по ссылке в раздел "Редакция журнала".

\section{Уважаемые авторы!}

С декабря 2006 года выходит в свет научно-теоретический журнал "Ойкумена. Регионоведческие исследования". Редколлегия журнала приглашает преподавателей вузов, сотрудников академических учреждений Приморского края и дальневосточного региона, а также всех заинтересованных исследователей публиковать свои статьи, материалы и методические разработки на страницах нашего издания.

Журнал будет включать в себя следующие тематические рубрики:

จ Теория и методология регионоведческих исследований

$\checkmark$ Историческое регионоведение

Экономика и природопользование

- Социальные и демографические структуры

\ Культурные и идеологические фракторы регионализации

\ Политические отношения и управление регионом

- Мировая система и международные регионы

\ Междисциплинарные и системные исследования региона

Р Регион в документах и свидетельствах

$\checkmark$ Науковедение

$\checkmark$ Дискуссия

$>$ Рецензии и обзоры

$\checkmark$ Научная жизнь

Научные специальности и соответствующие им отрасли науки, по которым издание включено в Перечень рецензируемых научных изданий, в которых должны быть опубликованы основные научные результаты диссертаций на соискание ученой степени кандидата наук, на соискание ученой степени доктора наук:

07.00.02 - Отечественная история (исторические науки)

22.00.01 - Теория, методология и история социологии (социологические науки)

22.00 .03 - Экономическая социология и демография (социологические науки)

22.00.04 - Социальная структура, социальные институты и процессы (социологические науки)

23.00 .01 - Теория и фрилософия политики, история и методология политической науки (политические науки)

23.00 .02 - Политические институты, процессы и технологии (политические науки)

23.00.04 - Политические проблемы международных отношений, глобального и регионального развития (политические науки) 


\section{Требования к объему и оформлению предоставляемых в редакцию материалов}

1. Допустимые форматы файла: docx, odt.

2. Файл не должен содержать сложных стилей и форматирования, а также переносов. В заголовках не применять ПРОПИСНЫЕ символы. Простановка буквы ё обязательна.

3. Шрифт Times New Roman 14 кеглем через 1,5 интервала.

4. Поля : верхнее и нижнее -2 см., правое $-1,5$ см., левое $-2,5$ см.

5. Порядок оформления статьи: УДК, сведения об авторе (авторах) (Ф.И.О., ученая степень, ученое звание, место работы и должность, рабочий (домашний) телефон, е-mail), название статьи (не более 80 знаков), текст статьи, список литературы, аннотация (от 500 до 700 знаков), ключевые слова (от 5 до 10). Название, аннотация и ключевые слова предоставляются на русском и английском языках. Вся вышеуказанная информация высылается одним файлом. Файлу следует присваивать только имя (фамилию) автора.

6. Библиографические ссылки в тексте статьи оформляются квадратными скобками жирным шрифтом. В скобках сначала указывается порядковый номер цитируемой работы в списке литературы, затем, через запятую, номер страницы приведенной цитаты. Например: [2, с. 5]. Если страница не указывается, а дается ссылка на работы целиком, то их нумерация даётся через точку с запятой. Например: [2; 5; 7]. Ссылка на неопубликованный архивный документ помещается только в тексте самой статьи в круглых скобках, также жирным шрифтом. Например: (ГАПК. Ф. 1. Оп. 2. Д. 3. Л. 4-5); (Рукопись Иванова А. К. Из архива автора).

7. Расшифровка сокращений и аббревиатур (кроме общепринятых) обязательна (даётся в конце текста статьи). Например : ГАПК - Государственный архив Приморского края.

8. Нумерованный список литературы составляется в алфавитном порядке, по фамилиям первых авторов и названиям работ без учета соавторов и хронологии. В списке сначала указывается литература на кириллице, затем на латинице, и после в других системах письма. Библиографическое описание должно включать полное наименование книги или статьи, место издания, издательство, год, общее количество страниц (для статьи - страницы, на которых она помещена). Ссылка на Интернет в списке литературы оформляется следующим образом: Автор. Название материала // Название сайта, [Электронный ресурс]. URL: адресная строка (дата обращения: 31.12.2019).

9. Объем статьи - от 0,5 до 1,0 п.л. (от 20 до 40 тыс. зн. с пробелами). Объём других материалов - до 0,3 п.л.

10. Рисунки, карты, графики и другой иллюстративный материал принимаются в наиболее распространенных (eps, ai, jpeg, bmp, tif) dорматах, и предоставляются отдельными файлами. $\mathrm{K}$ графикам обязательно прилагать таблицу, на основании которой этот график сделан. Для всех подписей в графиках использовать только шрифт Arial Narrow. Указание источника иллюстраций - обязательно.

11. Ввиду черно-белой печати журнала цветовая гамма иллюстраций, графиков, карт и т. д. не должна содержать более трех цветов (черный, белый, серый 50 \%).

12. Материалы предоставляются в редакцию в электронном виде без архивации по электронной почте (е-mail: ojkum@rambler.ru).

Статьи проходят обязательное рецензирование.

Редакция оставляет за собой право отбора публикаций.

Файлы, подготовленные с нарушением требований, не рассматриваются. Плата за публикацию не взимается. 
Научное издание

\section{Ойкумена. Регионоведческие исследования научно-теоретический журнал}

2020 № 1 (52)

Подписано к печати 03. 03. 2020 г. Вышло в свет 24. 03. 2020 г. формат 70x108/16

Усл. п. л. 14,70. Уч. -изд. л. 16,85. Тираж 200 экз. Заказ Цена свободная

Издательство Владивостокского государственного университета экономики и сервиса 690014, г. Владивосток, ул. Гоголя, 41

Отпечатано во множительном участке ВГУЭС

690014, г. Владивосток, ул. Гоголя, 41 

